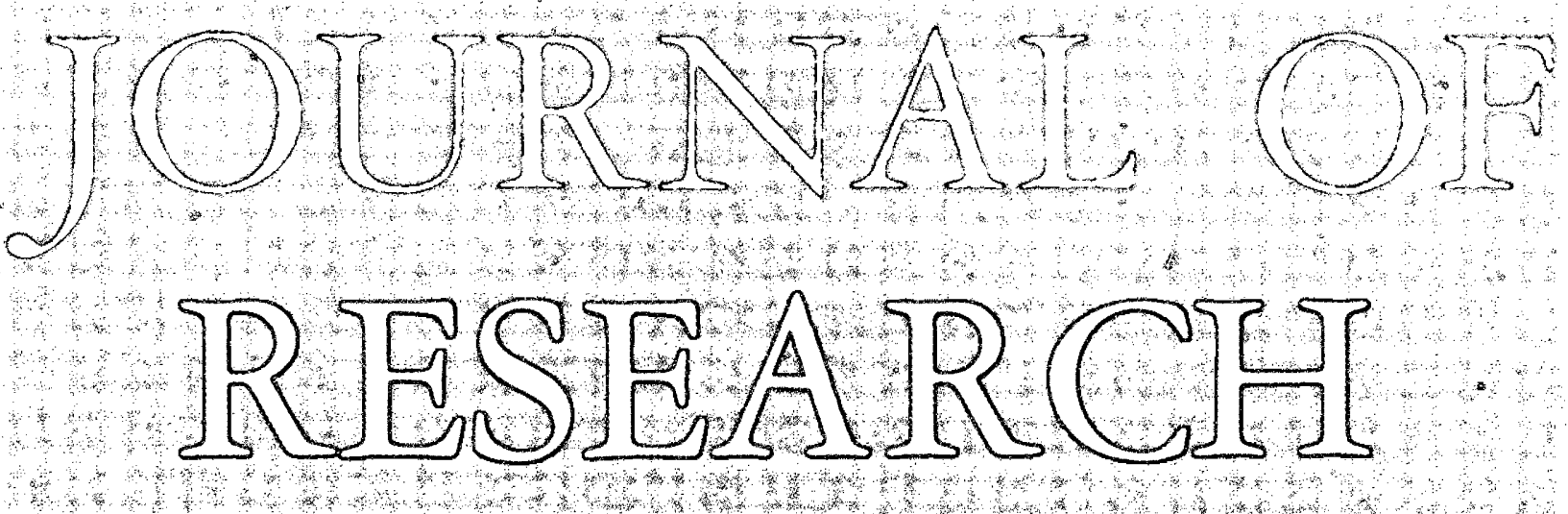

OR THE U.S. GEOLOGICAU SURVIY

SEPTEMBER-OCTOBER 1975

VOLUME 3, NUMBER 5

Scientific notes and summaries.

of investigations in geology,

bydrology, and related fields

U.S. DEPARTMENT OF THE INTERIOR 


\section{GEOLOGICAL SURVEY}

\section{E. McKelvey, Director}

For sale by the Superintendent of Documents, U.S. Government Printing Office, Washington, DC 20402. Annual subscription rate $\$ 18.90$ (plus $\$ 4.75$ for foreign mailing). Single copy $\$ 3.15$. Make checks or money orders payable to the Superintendent of Documents.

Send all subscription inquiries and address changes to the Superintendent of Documents at the above address.

Purchase orders should not be sent to the U.S. Geological Survey library.

Library of Congress Catalogcard No. 72-600241.
The Journal of Research is published every 2 months by the U.S. Geological Survey. It contains papers by members of the Geological Survey and their professional colleagues on geologic, hydrologic, topographic, and other scientific and technical subjects.
Correspondence and inquiries concerning the Journal (other than subscription inquiries and address changes) should be directed to Anna M. Orellana, Managing Editor, Journal of Research, Publications Division, U.S. Geological Survey, National Center 321, Reston, VA 22092.

Papers for the Journal should be submitted through regular Division publication channels.
The Secretary of the Interior has determined that the publication of this periodical is necessary in the transaction of the public business required by law of this Department. Use of funds for printing this periodical has been approved by the Director of the Office of Management and Budget through June 30, 1980.

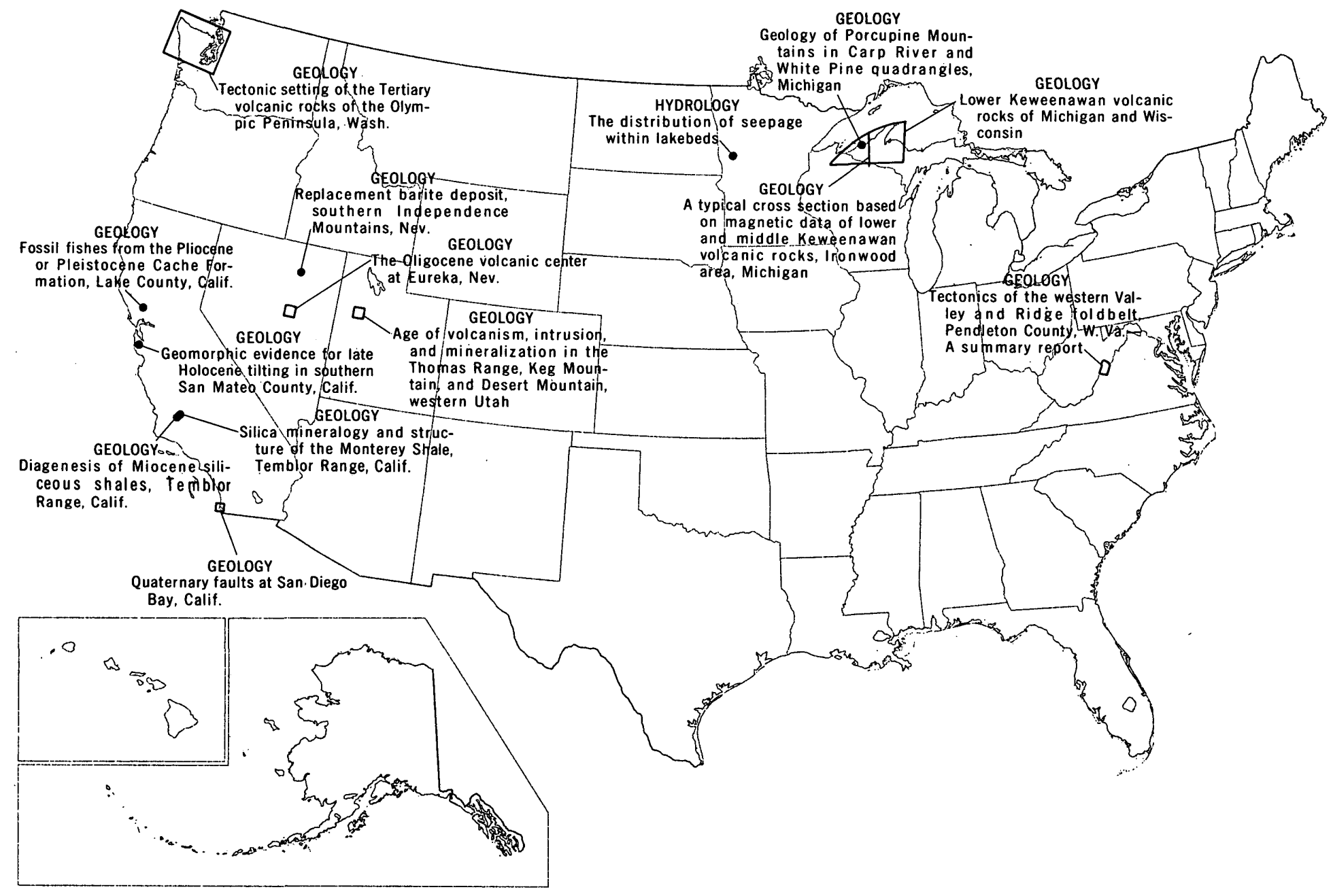

GEOGRAPHIC INDEX TO ARTICLES

See "Contents" for articles concerning areas outside the United States and articles without geographic orientation: 


\title{
JOURNAL OF RESEARCH
}

\author{
of the
}

\author{
U.S. Geological Survey
}

Vol..3 No. 5

\section{CONTENTS}

Abbreviations

\section{HYDROLOGIC STUDIES}

The distribution of seepage within lakebeds

M. S. McBride and H. O. Pfannkuch 505

Evaluation of stochastic models describing movement of sediment particles on riverbeds.

Petar Todorovic and C. F. Nordin, Jr.

\section{GEOLOGIC STUDIES}

Geology of Porcupine Mountains in Carp River and White Pine quadrangles, Michigan

Lower Keweenawan volcanic rocks of Michigan and Wisconsin

A typical cross section based on magnetic data of lower and middle Keweenawan volcanic rocks,

Ironwood area, Michigan

E. R. King

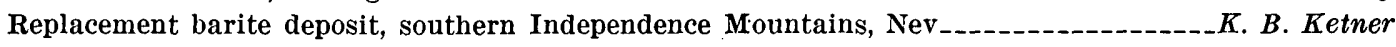

Diagenesis of Miocene siliceous shales, Temblor Range; Calif _._._-_K. J. Murata and $R$. R. Larson

Silica mineralogy and structure of the Monterey Shale, Temblor Range, Calif

K. J. M urata and R. G. Randall

Tectonic setting of the Tertiany volcanic rocks of the Olympic Peninsula, Wash_-_._.W. M. Cady

Tectonics; of the western Valley and Ridge foldbelt, Pendleton County, W. Va.-A summary report_G. W. Moore and M. P. Kennedy

Quaternary faults at San Diego Bay, Calif

Age of volcanism, intrusion, and mineralization in the, Thomas Range, Keg Mountain, and Desert Mountain, western Utah._-_._._. Lindsey, C. W. Naeser, and D. R. Shawe The Oligocene volcanic center at Eureka, Nev

M. C. Blake, Jr., E. H. McKee, R. F. Marvin, M. L. Silberman, and T. B. Nolan

Geomorphic evidence for late Holocene tilting: in southern San Mateo County; Calif_._.D. P. Adam

Fossil fishes from the Pliocene or Pleistocene Cache Formation, Lake County, Calif

R. W. Casteel and M.J. Rymer

Revised value for the $\mathrm{O}^{18}$ fractionation between $\mathrm{CO}_{2}$ and $\mathrm{H}_{2} \mathrm{O}$ at $25^{\circ} \mathrm{C}$ :

J. $R$, $0^{\prime}$ il $T$. Adami, and Samuel Epstein

pectrochemical determination of trace elements in galena.

E. L. Mosier,

519

529

543

547

553

567

573

583

589

597

605

613

619

623

625

Recent publications of the U.S. Geological Survey. Inside of back cover 


\section{ABBREVIATIONS}

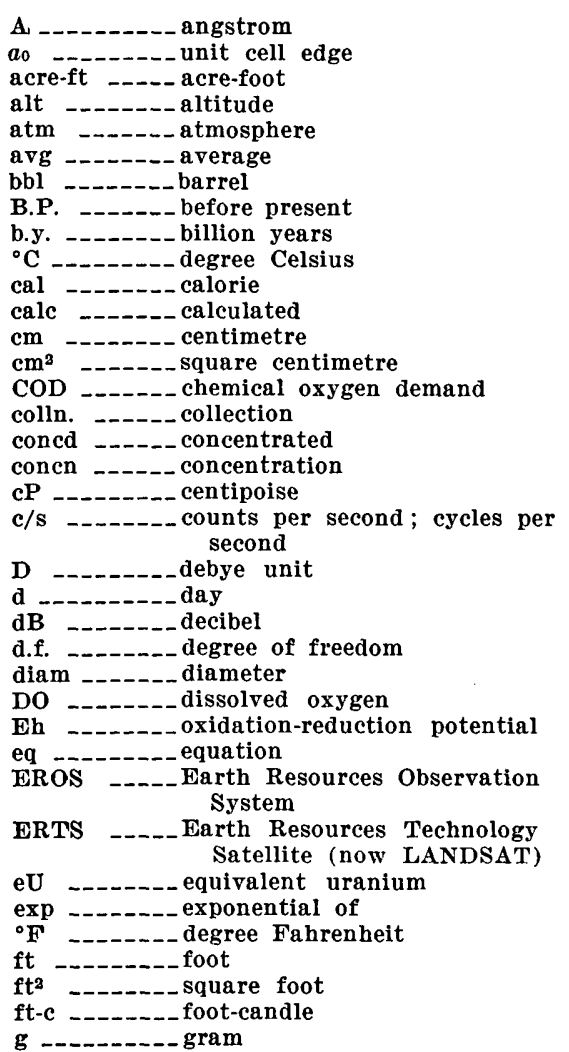

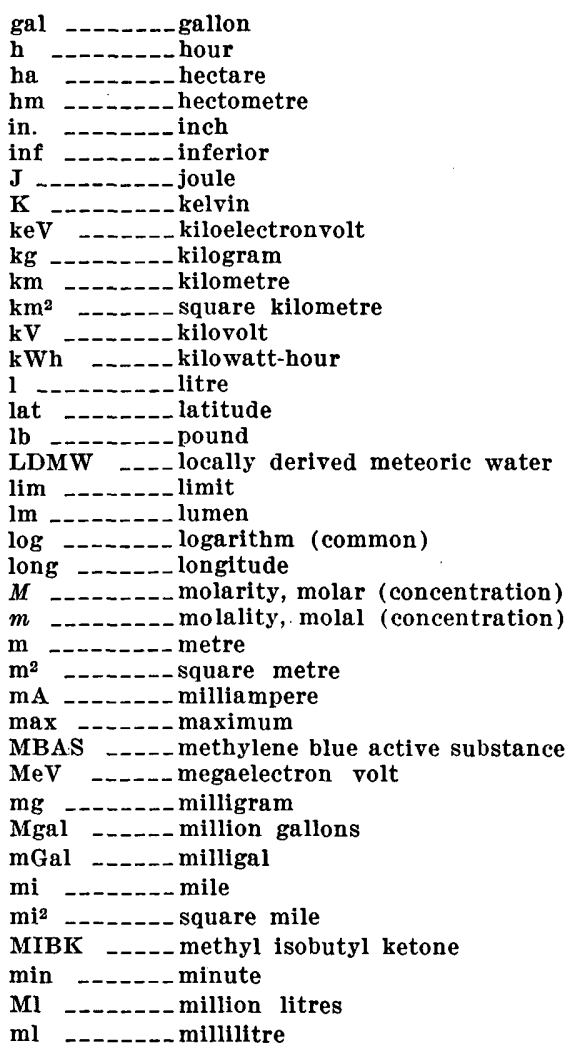

\section{CORRECTION}

We offer our apologies to Dr. G. J. S. Govett and Mrs. M. H. Govett for the concern that our reference in the "Journal of Research of the U.S. Geological Survey" (Vol. 3, No. 1, p. 9) has caused them. We had no intention of misquoting or misconstruing what they had written but intended to refer to their discussion on concepts of mining whole rocks or large parts of the Earth's crust. The reference was misplaced in the sentence that reads:

"Some (Govett and Govett, 1972, p. 285) hold that the resource base

of a commodity is the total amount within all the Earth's crust."

The sentence should read:

"Some hold that the resource base of a commodity is the total amount within all the Earth's crust as discussed by Govett and Govett (1972, p. 285)."

Norman J Page.

S. C. Creasey.

Any use of trade names and trademarks in this publication is for descriptive purposes only and does not constitute endorsement by the U.S. Geological Survey. 
Jour Research U.S. Geol. Surve

Vol. 3, No. 5, Sept.-Oct. 1975, p. 505-512

\title{
THE DISTRIBUTION OF SEEPAGE WITHIN LAKEBEDS
}

\author{
By M. S. MCBRIDE and H. O. PFANNKUCH, ${ }^{1}$ \\ Saint Paul and Minneapolis, Minn.
}

Work done in cooperation with the U.S. Environmental Protection Agency

\begin{abstract}
The mutual exchange of water between lakes and contiguous permeable ground-water bodies, which are thin relative to the diameter of the lakes, was modeled digitally. $\mathbf{A}$ significant rate of seepage was found to extend only a relatively short distance from shore, thus forming a narrow band around the lake's perimeter. This near-shore concentration of seepage is an effect only of the geometry of the ground-water flow system, which is governed by the geometry of the body of permeable material, the spatial distribution of permeability within it, and the form of the water table. Near-shore seepage occurs independently of the presence of fine-grained, lowpermeability sedimentary bottom materials in the central part of the lake. Digital modeling indicates that the velocity of seepage generally decreases at an exponential rate as a function of distance from shore. Field measurements of seepage rates through the bottom of Lake Sallie, west-central Minnesota, confirm the model results by demonstrating that both the near-shore seepage band and the exponential decrease in seepage velocity actually exist.
\end{abstract}

Recent field studies (Allred and others, 1971; Sloan, 1970, 1972; and Shjeflo, 1968) have demonstrated significant interchange between lakes and ground-water bodies in hydrogeologic situations where such interchange might intuitively seem unlikely. From these studies and others, we are convinced that lakes, rather than being isolated from ground-water bodies by lakebottom sediments, are generally in close connection with them, forming integral parts of dynamic groundwater flow systems.

This paper deals with seepage in the sense of water moving across the interface between a porous medium and open water or air. Its purpose is to consider how such seepage is distributed over the bottoms of natural lakes; that is, to determine where the rate of seepage is greatest and where least. We determined this first by use of simple but realistic mathematical models and second by field measurements of seepage rates.

The present studies apply to situations in which the width of the lake is greater than, or at least comparable to, the thickness of permeable material underlying the

\footnotetext{
${ }^{1}$ Department of Geology and Geophysics, University of Minnesota.
}

lake. This is generally the situation in Minnesota and Wisconsin, where the glacial drift is seldom more than $150 \mathrm{~m}$ thick and where most lakes are greater than $150 \mathrm{~m}$ wide. In many places, moreover, a low-permeability layer within the drift may form an effective base for the near-surface ground-water flow, and the thickness of permeable material beneath the lake may be considered to be much less than the total thickness of the drift. Freeze and Witherspoon (1967) have shown that a layer only one order of magnitude lower in permeability than the surface layer can form an effective lower limit to a near-surface ground-water flow system.

\section{FORMULATION OF MATHEMATICAL MODELS}

The relation between ground-water flow systems and lakes is shown diagrammatically in figure 1 . Flow systems are bounded above by the water table and below by low-permeability materials. Ground-water flow diverges from ground-water divides, converges on some lakes, and diverges from others. Many lakes probably receive inward seepage through part of their beds and discharge water to the ground through another part.

To evaluate the distribution of seepage through a lake's bottom, we first calculated the distribution of head within the permeable materials near the lake and then calculated the rate of seepage to or from the lake, as a function of position on the lake bottom, by Darcy's law.

The modeling approach used assumes the following:

1. Ground-water flow is two dimensional, as would occur if the lake shores and ground-water divides were straight, parallel, and infinitely long.

2. The principal axes of permeability are everywhere alined with the coordinate axes; that is, maximum permeability is always in the horizontal direction and minimum permeability in the vertical direction. 


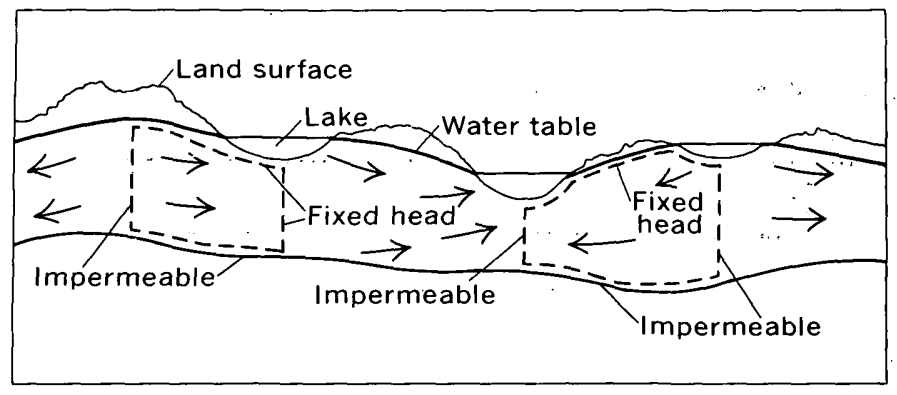

Figure 1.-Relation between lakes and ground-water flow. Two regions appropriate for modeling are shown by dashed lines

3. While layers may be present with permeability differing from layer to layer, within each layer the permeability is everywhere the same.

4.: Position of the water table is constant. The model is thus steady state.

5. The permeable materials are thin in comparison to the width of the lake.

6. Under steady-state conditions, the distribution of head conforms to a generalized form of Richards' equation (Richards, 1931) :

$\frac{\partial}{\partial x}\left[K x(x, z) \frac{\partial \phi}{\partial x}\right]+\frac{\partial}{\partial z}\left[K z(x, z) \frac{\partial \phi}{\partial z}\right]=0$

in which $\phi=$ hydraulic head, defined as the height above some arbitrary level to which water will rise in a tube whose lower opening is at the point where head is to be specified,

$K x(x, z)=$ hydraulic conductivity at point $(x, z)$ in the $x$-direction, and

$K z(x, z)=$ hydraulic conductivity at point $(x, z)$ in the $z$-direction.

This equation can be solved to give head as a function of $x$ and $z$ within a region, if boundary conditions are specified along the region's edges. The boundary conditions imposed are shown in figure 1, in which two appropriate regions for modeling are bounded by dashed lines. Along the water table; the head (that:is, the altitude of the water table) is known from field observations or is assumed for hypothetical problems. Along the bottom of each region, an impermeable boundary is assumed.

Side boundaries are not so easy to define. Places where ground-water flow diverges, as at ground-water divides, or converges, as at the center of the middle lake in figure 1, are modeled as impermeable (imaginary) boundaries. As a first approximation', 'we have assumed such boundaries to be straight " and vertical. Beneath a lake both fed from and feeding a groundwater body, there must be an equipotential line having the same head as the lake.. In situations where the lower boundary is close to horizontal, this equipotential line is nearly vertical. (In the absence of field data it may be modeled as being at the center of the lake.) The modeling program was constructed so that any vertical boundary could be made either impermeable or constánt head.

In this study, Richards' equation was solved numerically, using the point successive over-relaxation method, details of which may be found in standard texts (von Rosenberg, 1969; Mitchell, 1969). The mathematical methods are not new, being based on the work of Freeze and Witherspoon (1966).

\section{SEEPAGE AS PREDICTED BY MODELS}

The results obtained from the models may best be understood by examining one model in detail. Figure $2 A$ illustrates a model with isotropic porous materials, horizontal lower boundary, and impermeable side boundaries. Numbered lines are equipotential lines; the units of head are arbitrary.

Except for equipotential 10 which is affected by vertical flow near the divide, the equipotential lines are nearly vertical; thus, ground-water flow is nearly horizontal through most of the section.

Figure $2 B$ represents the left third of figure $2 A$, with the vertical exaggeration adjusted so that flow lines orthogonal to the equipotential lines may be shown in greater detail near the lakeshore. Note in figure $2 B$ that flow lines that emerge beneath the lake are concentrated close to shore, where most seepage enters in a narrow band, rather than being distributed uniformly over the entire bottom.

Concentrated seepage below lake level may be quantitatively evaluated by determining the relation between seepage rate and distance from shore. The numerical method used in this study yields values of head at a finite number of nodal points, which cover the region of interest in a regular rectangular grid. Therefore, in figure $2 B$, imagine one column of nodes to the right of the lake edge and an adjacent column to the left. The flux from a node in the right column to the adjacent node in the left column is the difference in heads divided by the horizontal distance, multiplied by the vertical distance and by the horizontal hydraulic conductivity. This is simply an application of Darcy's law. Fluxes so calculated for each pair of nodes along the columns are summed to give the total horizontal flux between the two columns.

Horizontal fluxes can -be calculated in the same way between all pairs of nodal' columins lying beneath the lake. Fluxes so calculated are plotted against distance from shore on a semilogarithmic grid in figure $2 C$. A straight line seems to fit the data satisfactorily, implying that flux decreases exponentially with distance. 


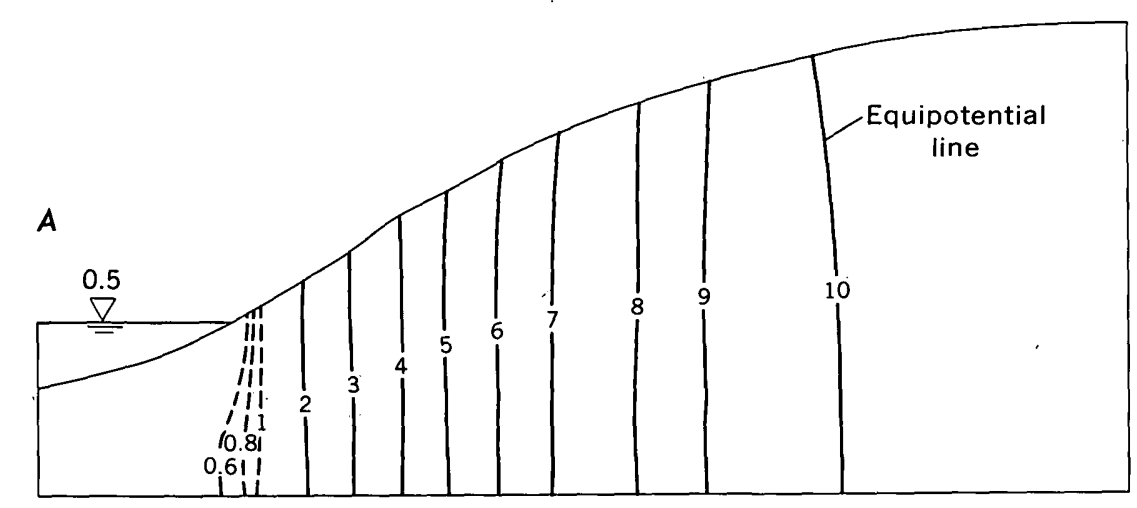

B

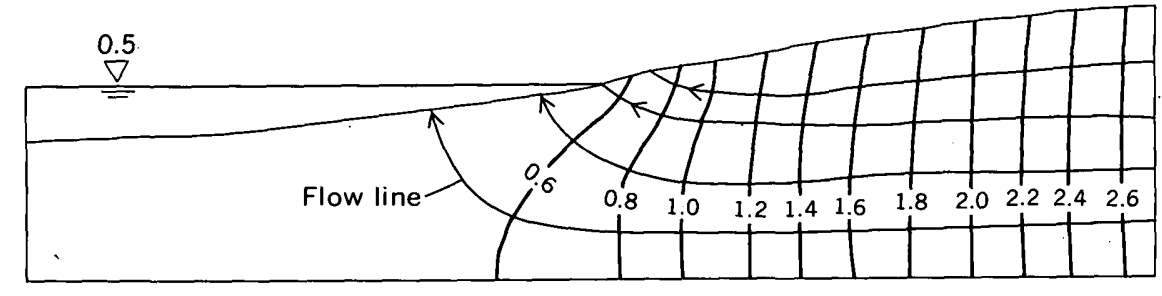

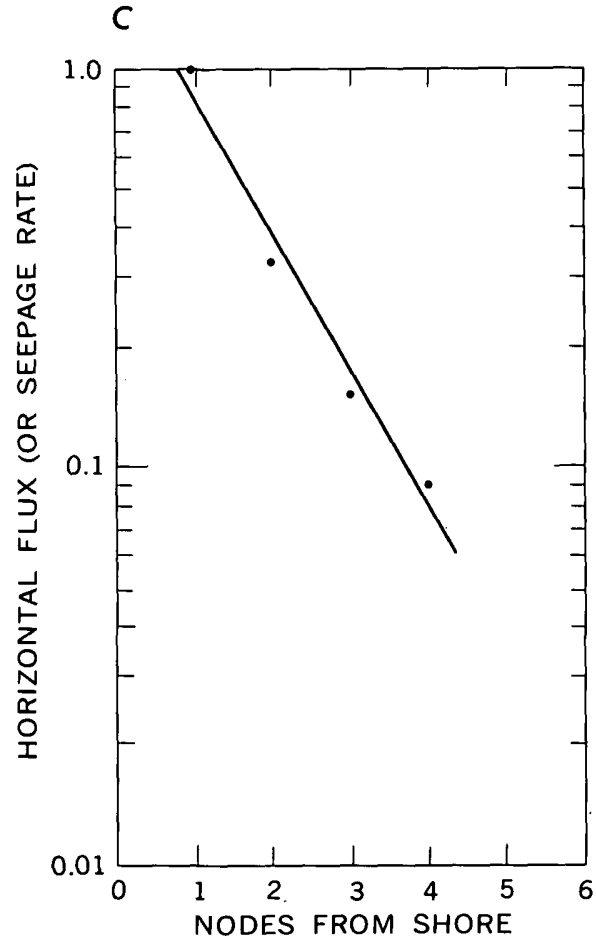

Frgure 2.-A typical vertical-section model. $A$, Potential distribution in the entire section. $B$, Left third of entire section showing near-shore concentration of flow lines. $C$, Relation between horizontal flux (or seepage rate) and distance from shore.

That is, the flux can be represented approximately as a function of distance from shore by an equation of the form $f=f_{0} \mathrm{e}^{-c x}$, where $f$ is the total flux across a vertical line through the aquifer at a distance $X$ from shore, $f_{0}$ the flux at the shoreline, and $-c$ is the slope of graph of flux against distance on semilogarithmic coordinates, as shown in figure $2 C$. However, seepage into or from the lake is of primary interest, rather than horizontal ground-water flux in the aquifer. The seepage into or from the lake, per unit width of lakebed, is equal to the rate of change of the horizontal flux with distance, since change in flux implies a loss or gain in flow which can occur only by seepage through the lakebed. In equation form,

$$
I / w=\frac{\mathrm{d}}{\mathrm{d} X}\left(f_{0} \mathrm{e}^{-c X}\right)=-c f_{0} \mathrm{e}^{-c X}
$$

where $I / w$ is the seepage rate per unit width of lakebed, and the term $-c f_{0}$ is equal to the seepage rate at the lakeshore.

These equations show that a plot of seepage rate per width of lakebed against distance from shore, on semilogarithmic coordinates, will be a straight line having the same slope as a plot of horizontal ground-water flux against distance from shore. If the flux and seepage terms are plotted in dimensionless form, by dividing each flux by the flux at the shoreline, $f_{0}$, and each seepage rate by the seepage rate at the shoreline, $-c f_{0}$, the two plots become identical. In equation form,

$$
\frac{f}{f_{0}}=\frac{I / w}{(I / w)_{0}}=\mathrm{e}^{-c \boldsymbol{X}} \text {. }
$$

Thus, a plot of horizontal flux in dimensionless form against distance from shore, such as that shown in figure $2 C$, can be taken equivalently as a plot of seepage rate in dimensionless form against distance from shore.

Ten model runs for selected parameter values are illustrated in figure 3 to show the effect of the shape of the water table and subsurface hydraulic conductivity variations on the near-shore concentration of seepage. In these illustrations, the vertical scale has been exaggerated about 16 times. However, because the ratio of horizontal to vertical hydraulic conductivity has been assumed equal to 10 for each model, the vertical exaggeration for equivalent isotropic models would be about 5 times. Because of this scale distortion, vertical flow components are less pronounced than might be anticipated. Data points represent flux values on the graphs accompanying the models, but the straight lines through them can equally well be taken to represent seepage. Table 1 summarizes hydraulic conductivities of the various layers and boundary conditions in the models, as depicted in figures 2 and 3. 

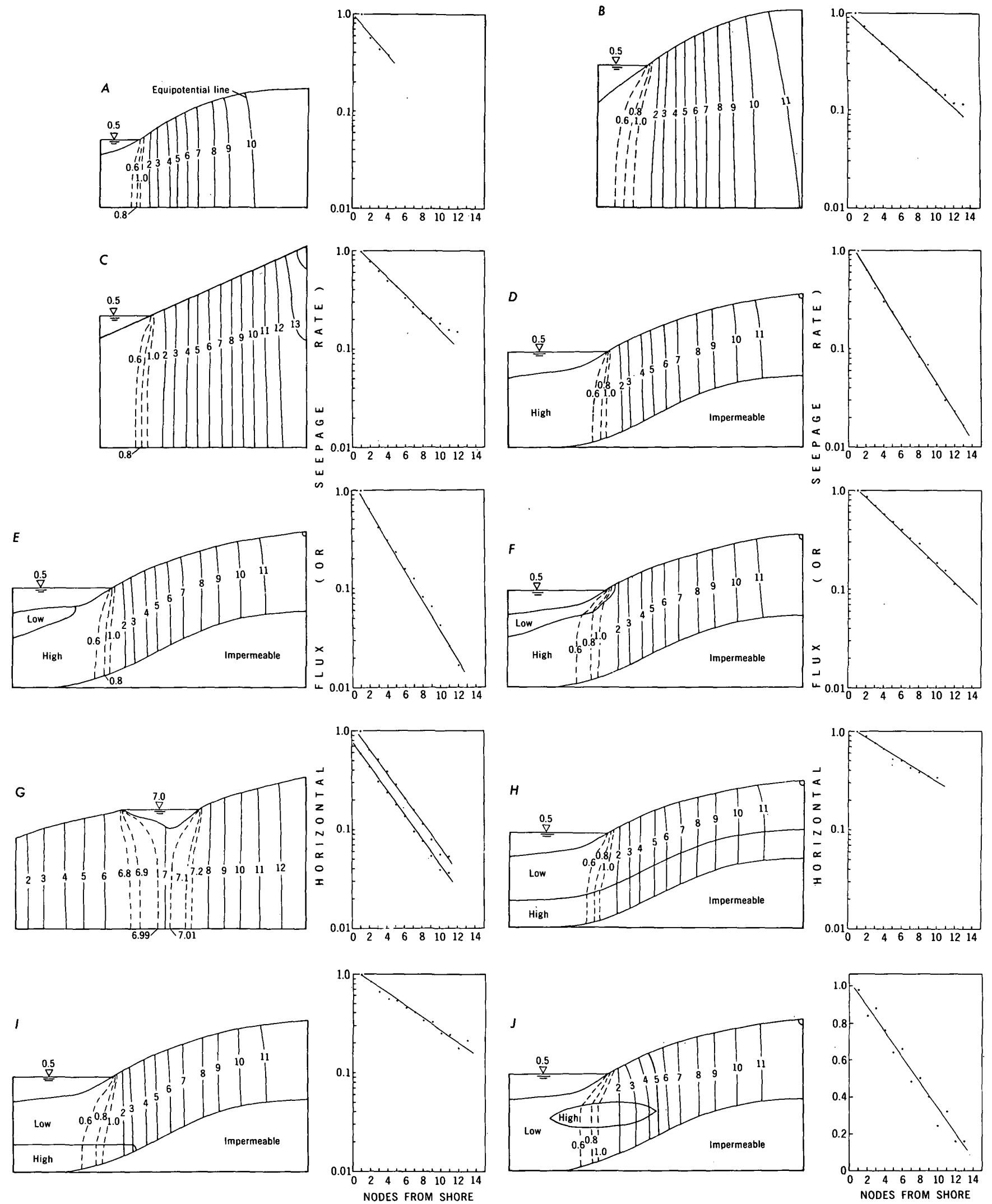

Figure 3.-Vertical-section models having various boundary and internal conditions. Low and high indicate degree of permeability. 
TABLE 1.-Parameters used in theoretical models [I, impermeable; C, constant head]

\begin{tabular}{|c|c|c|c|c|c|c|c|}
\hline \multirow{3}{*}{\multicolumn{2}{|c|}{$\begin{array}{c}\text { Figure } \\
\text { No. in } \\
\text { text }\end{array}$}} & \multicolumn{4}{|c|}{ Hydraulic conductivity (arbitrary units) } & \multirow{2}{*}{\multicolumn{2}{|c|}{$\begin{array}{l}\text { Boundary } \\
\text { condition }\end{array}$}} \\
\hline & & \multicolumn{2}{|c|}{ Larger layer } & \multicolumn{2}{|c|}{ Smaller layer } & & \\
\hline & & Horizontal & Vertical & Horizontal & Vertical & & \\
\hline 2 & & 1,000 & 100 & $\ldots$ & -- & I & I \\
\hline $3 A$ & & 1,000 & 100 & -..- & --- & I & $\mathrm{C}$ \\
\hline $3 B$ & & 1,000 & 100 & $\ldots$ & -- & $\mathrm{I}$ & I \\
\hline $3 C$ & & 1,000 & 100 & $\ldots$ & -- & I & I \\
\hline $3 D$ & $-\cdots$ & 1,000 & 100 & $-\ldots$ & --- & I & $\mathrm{C}$ \\
\hline $3 E$ & & 1,000 & 100 & 1 & $\overline{1}$ & I & $\mathrm{C}$ \\
\hline $3 F$ & & 1,000 & 100 & 1 & $\overline{1}$ & $\bar{I}$ & $\mathrm{C}$ \\
\hline $3 G$ & $-\ldots$ & 1,000 & 100 & & & $\mathrm{C}$ & C \\
\hline $3 H$ & $-\cdots$ & 100 & 10 & 1,000 & 100 & I & I \\
\hline $3 I$ & $\ldots$ & 100 & 10 & 1,000 & 100 & I & $\mathrm{C}$ \\
\hline $\mathbf{B} \boldsymbol{J}$ & - & 10 & 1 & 1,000 & 100 & $\bar{I}$ & C \\
\hline
\end{tabular}

Figure $3 A$ is identical to figure 2, except that the depth of the section is greater. Note that the seepage rate in figure $3 A$ falls off more slowly with distance than in figure $2 A$ because of greater transmissivity.

Figure $3 B$ and $3 C$ differ only in the forms of their water tables. In figure $3 B$ the water table is a parabola and in figure $3 C$ a straight line. The graphs of seepage are similar. Evidently here the concentration of seepage is controlled by a constant-head boundary at the lake bottom, rather than by the form of the water table away from the lake.

Figures $3 D, E$, and $F$ illustrate the effect of lowpermeability bottom sediments. In $D$, such sediments are absent. In $E$, they cover the central two-thirds of the lakebed and in $F$, the entire bed. The seepage graphs for $D$ and $E$ coincide over most of their lengths. Over 95 percent of the seepage enters the lakes in the regions where the graphs are coincident. The end of the graph in $E$ turns down sharply, evidently affected by the edge of the sediments. $F$ shows a considerably different result. The sharp bending of the equipotential lines near shore, where they pass from underlying high-permeability materials into low-permeability lake sediments, reveals that flow is much more nearly vertical in the lake sediments than in the material below. In effect, low-permeability sediments spread out seepage under more of the lake by slowing flow into the lake. The result is clear from the seepage graph for $F$ whose slope is only half as great as those shown in $D$ and $E$.

Figure $3 G$ shows a lake connected with a sloping water table. Water flows into the lake on the right side and out on the left. Note that the water table was sketched so that the horizontal flux toward the lake was greater than that away from it. Both in and out fluxes were made dimensionless by dividing them by the flux toward the lake, so the two graphs are displaced from one another. In a real lake, a difference between ground-water fluxes toward and away from the lake could be accounted for by losses from the lake by streamflow or evaporation. These components of a lake's water balance are not explicitly included in this model.

Little of the ground-water flow passes beneath the lake. Instead, most is diverted upward as it approaches the lake, passes through the lake, moves downward, and eventually comes back to the horizontal. The graph of flux toward the lake shows that at 10 nodes from shore, or 40 percent of the way across the lake, the horizontal ground-water flux is 0.04 , or only 4 percent of its value at the lake shore. Thus, 96 percent of the ground water has entered the lake prior to this point. The same situation occurs on the outflow side of the lake. The lake's depth is 15 percent of the thickness of the underlying materials and its width about 110 percent if the materials are considered isotropic. These figures are reasonable for a real lake. We believe that it is common for most ground water flowing in the vicinity of a lake to be diverted through the lake, because real lakes are commonly several aquifer thicknesses in width.

Figures $3 H, I$, and $J$ have the same water table and lower boundary as figure $3 D$, but differ in having inhomogeneous permeable materials beneath the lakes. In $H$, the high-permeability layer at the bottom of the section serves to spread seepage somewhat more evenly across the lake bottom than in $D$. This is reflected in a smaller slope of the graph in H. A similar effect is shown in $I$, even though the high-permeability layer is less extensive, covering less than half the bottom of the section. In $J$, the high-permeability material forms a lens and lies much closer to the lake bottom than in $H$ and $I$. Evidently, this lens has a strong effect on the distribution of seepage, because here the decrease in seepage rate is linearly related to the distance from shore rather than exponentially, as in all the other figures. Note that the graph's grid is linear rather than semilogarithmic.

It may be concluded from these theoretical models that ground-water inflow is concentrated near the shores of lakes under a wide variety of hydrogeologic conditions and that in many places seepage rate will decrease exponentially with distance from shore.

\section{APPLICABILITY OF MODELS TO FIELD SITUATIONS}

The models presented in figures 2 and 3 , of course, do not cover all hydrogeologic situations. We believe, however, that the conclusions drawn from the models are applicable to a wide variety of lakes for the following reasons:

First, the model sections are nondimensional. No linear dimensions enter into Richard's equation (eq 1) or into any of the boundary conditions; thus, a given 
model may represent either a large field section or a small one. Figure 2, for example, can represent a lake a few tens of metres in diameter lying in permeable materials a few metres thick, or it can represent a lake several kilometres across lying in material hundreds of metres thick.

Second, the distribution of potential does not depend on magnitudes of permeabilities of the porous materials. This means in nonhomogeneous sections the forms of the equipotentials are governed by relative permeabilities of the various layers rather than by absolute values.

Third, each model may represent a variety of anisotropies and finite-difference grids. The horizontal flux between adjacent nodes whose heads differ by $\Delta \phi$ is given by Darcy's law as:

$$
Q x=K x \Delta z \frac{\Delta \phi}{\Delta x}
$$

where $K x=$ horizontal hydraulic conductivity, $\Delta z=$ grid spacing in vertical direction, and $\Delta x=$ grid spacing in horizontal direction.

The variables characterizing permeability and the grid geometry may be isolated in a single constant,

Similarly, for the vertical flux

$$
C x=K x \frac{\Delta z}{\Delta x} \text {. }
$$

$$
Q z=K z \Delta x \frac{\Delta \phi}{\Delta z} \text { and } C z=K z \frac{\Delta x}{\Delta z} \text {. }
$$

Each node of the model may, therefore, be characterized by a value of $C x: C z$, rather than by particular values of $K x, K z, \Delta x$, and $\Delta z$. A given model can represent any combination of permeabilities and node spacings for which, at each node, the term $\frac{K x(\Delta z)^{2}}{K z(\Delta x)^{2}}$ is equal to the value of $C x: C z$ characterizing that node.

In summary, the anisotropy can be varied as long as the ratio of coordinate spacings is varied is a compensating way. In all the models presented above, the ratio $\frac{\Delta z}{\Delta x}$ was set at 0.1 and the anisotropy $\frac{K x}{K z}$ at 10 for the largest layer; thus $\frac{C x}{C z}$ was 0.1 .

Situations certainly exist in which seepage is not concentrated along lake shores. An example is where the width of a lake is very small compared to the thickness of the underlying ground-water flow system. Freeze and Witherspoon (1966) have presented models of this condition in which the water table is undulating. These could represent regions of hummocky topography, where ground-water bodies are recharged in topographic highs and discharged by evaporation from small ponds in intervening depressions. The ponds have diameters much less than the thickness of the sections. The models show flow lines rising almost vertically to some of the depressions. Evidently, the seepage occurs almost uniformly across the bottoms of these depressions; thus, the concentration noted previously is absent.

The geologic possibilities are too diverse for a general rule to apply; but we may venture, on the basis of the models available, that near-shore concentration of seepage will be significant only where a lake's diameter is at least roughly comparable to the thickness of the underlying permeable materials.

\section{FIELD MEASUREMENTS OF SEEPAGE RATES}

Conclusions drawn from theoretical models are much more convincing when supported by field observations. Such observations of seepage were provided by Lee (1972) as part of a study of Lake Sallie, Becker County, west-central Minnesota. Lake Sallie has an area of $5.2 \mathrm{~km}^{2}$ and a mean depth of $6 \mathrm{~m}$. It is kidney shaped, $3.3 \mathrm{~km}$ long and $1.7 \mathrm{~km}$ wide, and lies in sandy glacial outwash which has an average thickness of $15 \mathrm{~m}$ and a hydraulic conductivity of about 0.1 $\mathrm{cm} / \mathrm{s}$. The outwash is underlain by a thick layer of clay till having a hydraulic conductivity of $3.5 \times 10^{-8}$ $\mathrm{cm} / \mathrm{s}$. Ground-water movement in the outwash is toward the lake along almost all of the lake's perimeter. Fourteen percent of the inflow to the lake is groundwater seepage.

Lee made several hundred measurements of the rate of seepage into Lake Sallie at distances from 3 to $110 \mathrm{~m}$ from shore. The seepage meter used is illustrated in figure 4 . The end of a steel drum was cut off to form a shallow metal collector pan that was imbedded, open side down, a few centimetres into the sand on the lake bottom. A thin-walled plastic bag, containing a weighed amount of water but no air, was attached to the tube. After a few hours or days, the bag was reweighed. Any water that seeped upward through the area of lake bottom covered by the pan was trapped

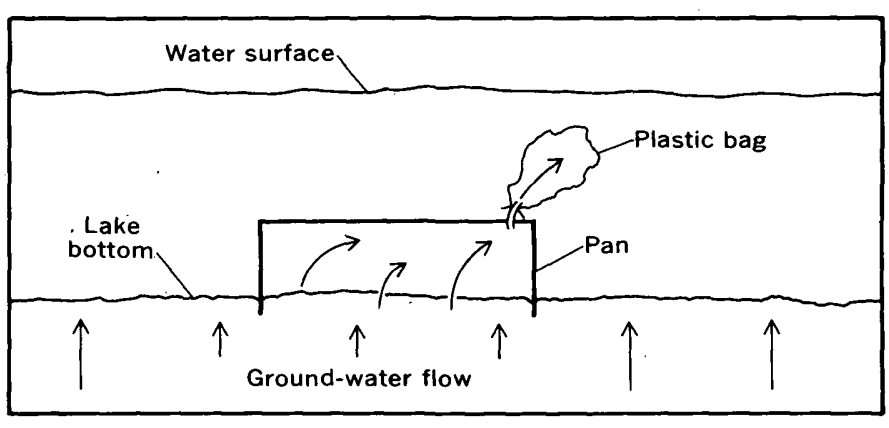

Frgure 4.-Operation of a seepage meter. 
and diverted into the plastic bag. The change in weight was converted to an equivalent volume of seepage which, when divided by the area of the pan and time for which the bag was connected, gave the seepage velocity.

A representative selection of the data is plotted in figure $5 A$ through $5 F$. Data in each graph come from measurements made close to a straight line extending perpendicularly from shore out into the lake. All lines of measurements are along a nearly straight part of the southwest shore of Lake Sallie. The distance from line $A$, on the north to line $F$, on the south, is about $800 \mathrm{~m}$. As much as possible the data in each graph are from a single month. When more than one measurement was made at a location, the results were averaged; thus, most data points in figure 5 represent two or more measurements.

Although there is much scatter, a straight line seems to fit the data as a satisfactory first approximation. Thus, the seepage rate decreases as an exponential function of distance from shore in the field examples, just as it did in the theoretical cross sections previously presented.

\section{WIDTH OF THE ZONE OF RAPID SEEPAGE}

The width of the zone of rapid seepage in a real lake was investigated using field data from Lake

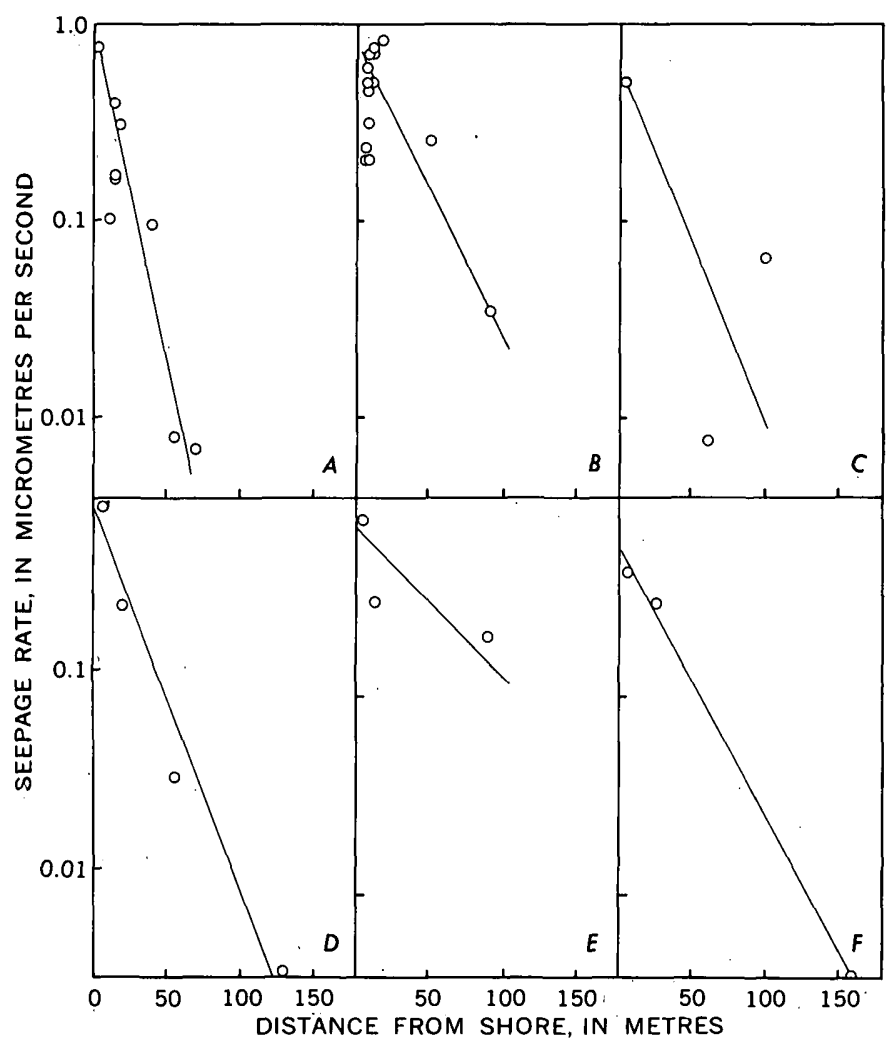

Figure 5.--Seepage rates as a function of distance from shore at Lake Sallie.
Sallie. Consider figure $6 \mathrm{~A}$; a strip of lake bottom $1 \mu \mathrm{m}$ wide extends perpendicularly from shore into the lake. The seepage velocity, $S$, is a function of the distance from shore, $X$, for points along the strip.

At Lake Sallie (fig. 5) the seepage velocity decreases one order of magnitude for every $60 \mathrm{~m}\left(6 \times 10^{7} \mu \mathrm{m}\right)$ of distance, approximately. The seepage velocity is about $0.6 \mu \mathrm{m} / \mathrm{s}$ at the shoreline. Here then, $\log S=$ $-\left(X / 6 \times 10^{7}\right)+\log 0.6$, or $S=0.6\left(10^{-\mathrm{x} / 6 \times 10^{7}}\right)$, where $S$ is expressed in micrometres per second and $X$ in micrometres. The total seepage rate from the strip, between the shore and a specific distance $L$ from the shore, is given by

$$
Q(L)=0.6 \int_{X=0}^{X=L} 10^{-\left(X / 6 \times 10^{7}\right)} \mathrm{d} X
$$

where $X$ is the variable of integration and $L$ is the upper limit.

Evaluating this integral analytically gives the formula

$$
Q(L)=-1.56 \times 10^{7}\left(10^{-\left(\mathrm{i} / 6 \times 10^{7}\right)}-1\right)
$$

for total seepage rate as a function of $L$.

If $L$ is taken at the center of Lake Sallie, about 1 $\mathrm{km}$ from shore, seepage through the entire strip amounts to $1.56 \times 10^{7} \mu \mathrm{m} / \mathrm{s}$. The percentage of this total taking place within a given distance from shore is shown in figure $6 B$. One-half of the discharge occurs within $17 \mathrm{~m}$ of shore, 90 percent within $60 \mathrm{~m}$, and 99 percent within $120 \mathrm{~m}$. Thus, at Lake Sallie, the width of the zone of high seepage is, roughly, $100 \mathrm{~m}$, or one-tenth the distance to the center of the lake. Note that the edge of the fine-grained sediments in the center of Lake Sallie is $300 \mathrm{~m}$ from shore at the location investigated. This again emphasizes the importance of the geometry of the ground-water system and the relatively small role that lake sediments may often have in controlling the distribution of seepage within lakes.
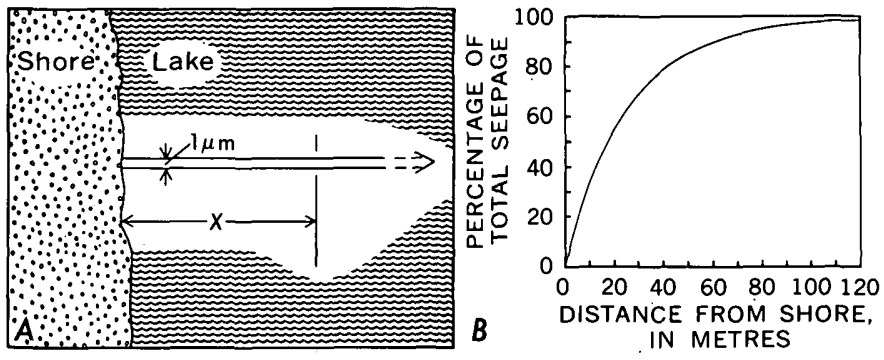

Froure 6.-Seepage from Lake Sallie. $A$, Strip of lake bottom used in calculating width of zone of rapid seepage. $B$, Percentage of total seepage occurring within a given distance from shore. 


\section{SUMMARY AND CONCLUSIONS}

Digital modeling of lake-ground water systems shows that seepage of water into or out of lakes tends to be concentrated near the shore. The seepage rate is greatest at the shore and decreases with increasing distance from shore. In many places, the rate of decrease is exponential. Hydrogeologic conditions exist where the decrease is linear, however, and, no doubt, more complicated situations occur in nature. For seepage concentration, the width of the lake cannot be much less than the thickness of the underlying permeable materials. This condition is not met in all lakes, but probably holds for many, if not most.

Field measurements at Lake Sallie demonstrated the existence of a zone of concentrated seepage near the shoreline. The measurements showed much scatter but indicated plainly that the decrease in seepage rate with distance from shore was approximately exponential. The rate of decrease was one order of magnitude for every $60 \mathrm{~m}$ of distance.

The investigations reported here suggest the possibility of using seepage measurements to determine the seepage component of lake-water balances independent of other components. Such a procedure would be cheaper and possibly more accurate than determining seepage as a residual in a water budget.

Because of the narrowness of the zone of rapid seepage, measurements of seepage rate can be confined to a small fraction of the total lakebed. Furthermore, this zone constitutes the shallowest and most accessible part of the lakebed. In many lakes, seepage measurements can be made by wading, rather than from boats or by diving. However, uncertainties must be cleared before this approach can be attempted with confidence. In particular, the causes of the large amount of scatter in the graphs of seepage rate against distance from shore (fig. 5) are unknown. Some possible causes are that (1) areal distribution of seepage may be irregular, with considerable variations in seepage rates within distances of a few metres, (2) unrecognized defects may exist in the measuring apparatus or in the experimental technique, and (3) seepage rates may fluctuate rapidly with time, perhaps as the result of changes in lake level or barometric pressure.

Another uncertainty concerns distribution of seepage throughout the year. Monthly water balances obtained by Mann and McBride (1972) suggest that almost all seepage into Lake Sallie occurs during March through June. Whether this is common or not is unknown. At present, it is hard to predict how many and how frequent seepage measurements should be made for adequate definition of the total annual seepage in a given lake.

Seepage has received less attention than some other components of lake-water balances. We hope that the results presented here will serve as steps toward obtaining a greater knowledge of seepage mechanisms, both through more detailed field studies and more realistic mathematical models.

\section{REFERENCES CITED}

Allred, E. R., Manson, P. W., Schwartz, G. M., Golany, Pinhas, and Reinke, J. W., 1971, Continuation of studies on the hydrology of ponds and small lakes: Minnesota Univ. Agr. Expt. Sta. Bull. 274, 62 p.

Freeze, R. A., and Witherspoon, P. A., 1966, Theoretical analysis of regional ground-water flow-1, analytical and numerical solutions to the mathematical model: Water Resources Research, v. 2, no. 4, p. 641-656.

- 1967, Theoretical analysis of regional ground-water flow-2, effect of water-table configuration and subsurface permeability variation: Water Resources Research, v. 3, no. 2, p. 623-634.

Lee, D. R., 1972, Septic tank nutrients in ground water entering Lake Sallie, Minnesota: Grand Forks, North Dakota University, M.S. thesis, 96 p.

Mann, W. B., IV, and McBride, M. S., 1972, The hydrologic balance of Lake Sallie, Becker County, Minnesota, in Geological Survey research 1972: U.S. Geol. Survey Prof. Paper 800-D, p. D189-D191.

Mitchell, A. R., 1969, Computational methods in partial differential equations: New York, John Wiley \& Sons, Inc., $255 \mathrm{p}$.

Richards, L. A., 1931, Capillary conduction of liquids through porous mediums: Physics, v. 1, p. 318-333.

Shjeflo, J. B., 1968, Evapotranspiration and the water budget of prairie potholes in North Dakota: U.S. Geol. Survey Prof. Paper 585-B, 49 p.

Sloan, C. E., 1970, Prairie potholes and the water table, in Geological Survey research 1970: U.S. Geol. Survey Prof. Paper 700-B, p. B227-B231.

- 1972, Ground-water hydrology of praiarie potholes in North Dakota: U.S. Geol. Survey Prof. Paper 585-C, 28 p.

von Rosenberg, D. U., 1969. Methods for the numerical solution of partial differential equations: New York, American Elsevier, 128 p. 


\title{
EVALUATION OF STOCHASTIC MODELS DESCRIBING MOVEMENT OF SEDIMENT PARTICLES ON RIVERBEDS
}

\author{
By PETAR TODOROVIC ${ }^{1}$ and CARL F. NORDIN, Jr. \\ Montreal, Canada, Denver, Colo.
}

\begin{abstract}
Various stochastic models have been proposed to describe the movement of sediment particles on the riverbed. Here it is attempted to summarize in an integrated form and to generalize the most important theoretical results in this field. The approach adopted in this paper is based on the fact that most of the stochastic models are only special cases of a particular kind of random walk on the straight line.
\end{abstract}

This paper represents the authors' attempt to review, summarize, and generalize the major theoretical results in certain fields of sediment transport and dispersion. We do not, however, report all the studies that have been published throughout the years on the topic which we discuss.

Sediment transport rate and dispersion are relevant to many engineering and environmental problems, such as river basin management, design of various hydraulic structures, operation and maintenance of canals and reservoirs, and so on. One of the major transporting media of chemical and other industrial wastes in natural waterways is sediment. There is considerable evidence that these wastes are adsorbed by sediment particles. Thus, in the event that some toxic material is discharged into a stream, the sediment may remove most of it from the solution, and thereafter, the lateral and longitudinal dispersion of sediment particles will reduce the concentration level of the toxic substance.

Various methods have been developed for determining the transport rate and dispersion of sand by water flowing over a sand bed (Einstein, 1937; Crickmore and Lean, 1962; Hubbell and Sayre, 1964; and others). All these methods are specific cases based on the general theory of random walk on the line. In the following, this fact is used to present these results in an integrated and generalized form.

Acknowledgment.-The senior author was supported in part by the National Research Council of Canada, Grant: CNR-A-8959. The support is gratefully acknowledged.

\section{VARIOUS MODELS OF PARTICLE MOVEMENT}

Suppose a set of tagged particles with identical transport characteristics was released onto a strip of a channel bottom (fig. 1) at time $t=0$. Let us single out a particle and denote by $X(t)$ the traveled distance in the downstream direction at $t>0$. It is assumed that

$$
X(0)=0,0 \leqslant X(t) \leqslant X(t+\Delta t) \text {, and } \Delta t>0 \text {. }
$$

Such a particle undergoes a particular kind of random walk along the bottom of the channel. It moves in a series of steps of random length, with a rest period of random duration between two consecutive steps. In all models it is invariably assumed that

$$
X^{\prime \prime}(t)=\sum_{\nu=0}^{\eta(t)} \xi_{\nu}\left(\xi_{0}=0\right)
$$

where $\xi_{\nu}>0$ is the length of $v$ th step of the particle in longitudinal direction, and $\eta(t)$ is the number of steps completed in $[0, t]$. It is clear that the fraction $F_{t}(x)$ of the tagged particles on the distance less than $x>0$ at time $t$ is approximately determined by

$$
F_{t}(x)=P[X(t) \leqslant x]
$$

where $P$ denotes probability.

In Crickmore and Lean's version of the random walk, steps are nonrandom and all are the same length $L$. In addition to this, the time to travel $L$ is a constant $T$ and the probability that the motion takes place at any time $k T$ is a constant $p$. Hence we have

$$
X(t)=\eta(t) \cdot L
$$

where $t=n T$

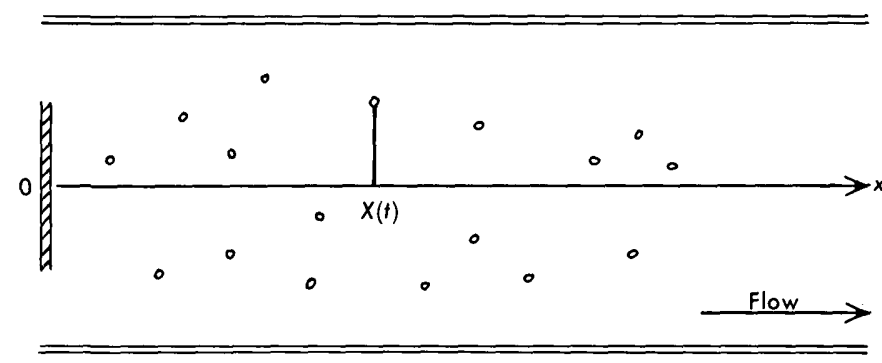

Figure 1.-Schematic presentation of dispersion of tagged particles on the bottom.

${ }^{1}$ Ecole Polytechnique, Montreal, Canada. 
and for any $k=0,1, \ldots, n$,

$$
P[X(t)=k L]=P[\eta(n T)=k]=\left(\begin{array}{c}
n \\
k
\end{array}\right) p^{k} q^{n-k}
$$

where $p+q=1$.

Einstein (1937) hypothesized that the step-lengths $\xi_{1}, \xi_{2}, \ldots$ were mutually independent random variables with the common distribution function

$$
P\left(\xi_{\nu} \leq x\right)=\left[\begin{array}{ll}
1-\mathrm{e}^{-\lambda_{2} x}, & x \geqslant 0 \\
0, & x<0
\end{array}\right.
$$

and independent of $\eta(t)$, while for every $t>0$

$$
P[\eta(t)=n]=\mathrm{e}^{-\lambda_{1} t} \frac{\left(\lambda_{1} t\right)^{n}}{n !} .
$$

On the basis of these assumptions we have

$$
\begin{aligned}
F_{t}(x) & =P\left(\sum_{\nu=0}^{\eta(t)} \xi_{\nu} \leq x\right)=P\left\{\sum_{\nu=0}^{\eta(t)} \xi_{\nu} \leq x, \bigcup_{n=0}^{\infty}[\eta(t)=n]\right\} \\
& =\sum_{n=0}^{\infty} P\left(\sum_{\nu=0}^{n} \xi_{\nu} \leq x\right) P[\eta(t)=n] .
\end{aligned}
$$

Since

$$
P\left(\sum_{\nu=1}^{n} \xi_{\nu} \leq x\right)=\frac{\lambda_{2}{ }^{n}}{\Gamma(n)} \int_{0}^{s} u^{n-1} e^{-\lambda_{2} u} \mathrm{~d} u
$$

after transformation, the distribution function of equation 7 becomes

$$
F_{t}(x)=\mathrm{e}^{-\lambda_{1} t}\left[1+\sqrt{\lambda_{1} t} \int_{0}^{\lambda_{2} t} I_{1}\left(2 \sqrt{\lambda_{1} t u}\right) \frac{\mathrm{e}^{-u}}{\sqrt{u}} \mathrm{~d} u\right]
$$

where

$$
I_{p}(x)=\sum_{n=0}^{\infty} \frac{\left(\frac{x}{2}\right)^{2 n+p}}{n !(n+p) !}
$$

is the modified Bessell function of the first kind and order $p=0,1, \ldots$ The distribution function has a discontinuity at $x=0$ and therefore the corresponding density function does not exist.

The most general form of the distribution $F_{t}(x)$ (assuming that $\eta(t)$ and $\mu(x)$ are independent random variables for every $x \geqslant 0$ and $t \geq 0)$ is

$$
F_{t}(x)=P\left(E_{o}^{t}\right)+\sum_{n=1}^{\infty} \sum_{\nu=n}^{\infty} P\left(E_{n}{ }^{t}\right) P\left(G_{\nu}^{x}\right)
$$

(Todorovic, 1970) where $P\left(E_{n}{ }^{t}\right)=P[\eta(t)=n]$, $P\left(G_{\nu}{ }^{x}\right)=P[\mu(x)=\nu]$ and $\mu(x)$ denotes the number of steps of the particle in $[0, x]$.

Another way to study the movement is to consider the first passage time of the process $X(t)$. With regard to the definition of equation $2, X(t)$ is a stochastic process step (nondecreasing) sample function (fig. 2).

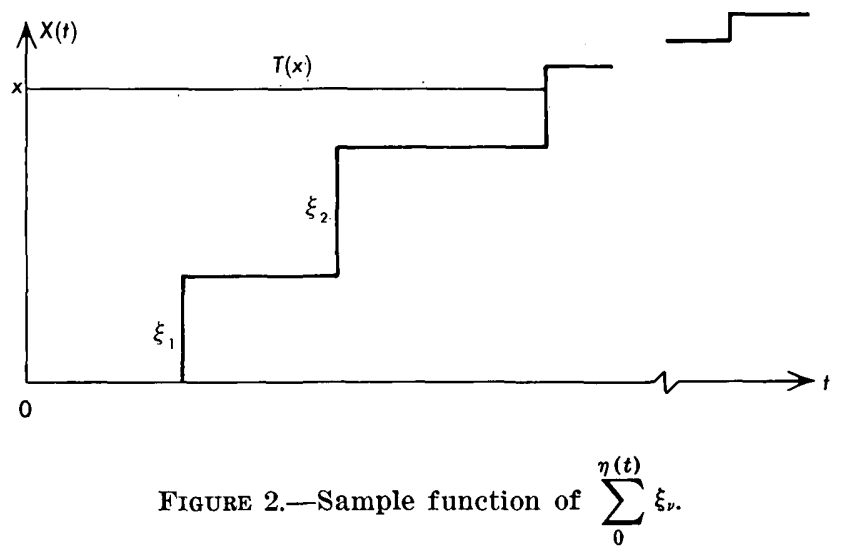

The first passage time $T(x)$ of the level $x$.is defined as

$$
T(x)=\inf [s ; X(s)>x]
$$

and has the property (Todorovic, 1967) that

$$
Q_{x}(t)=P\left[T^{\prime}(x) \leq t\right]=P[X(t)>x]=1-F_{t}(x) .
$$

The first approach is frequently called Lagrangian while the second one is termed Eulerian. Equation 10 relates these two descriptions. In contrast to the previous model, the distribution function $Q_{x}(t)$ is differentiable for every $t$, and its density function $q_{x}(t)$ is

$$
q_{x}(t)=\lambda_{1} \exp \left[-\left(\lambda_{1} t+\lambda_{2} x\right)\right] I_{0}\left(2 \sqrt{\lambda_{1} \lambda_{2} t x}\right) .
$$

\section{SOME REMARKS ON THE PREVIOUS MODELS}

If we denote by $\xi(t)$ the longitudinal velocity of the particle, then bearing in mind that it moves along the bed in a series of transport and rest periods, the velocity $\xi(t)$ represents a nonnegative intermittent stochastic process (fig. 3) positive on random intervals of time. Denote by $\tau(k)$ the right end of the $k$ th interval (as in the previous section $\eta(t)$ is the number of steps, or equivalently the number of $\tau(k)$ in $[0, t])$. Since physical intuition is not violated by assuming $\xi(t)$ to be stochastically continuous, it represents a separable and measurable random function (Skorokhod, 1965). Thus, the following integrals exist:

$$
\begin{aligned}
X(t)=\int_{0}^{t} \xi(s) \mathrm{d} s \text { and } \xi_{k}=\int_{\tau(k-1)}^{\tau(k)} \begin{array}{l}
\xi(s) \mathrm{d} s \\
{[\tau(0)=0] .}
\end{array}
\end{aligned}
$$

The first integral represents the distance traveled by the particle at time $t$, and $\xi_{k}$ is the length of $k$ th step. Write $X(t)$ as

$$
\int_{0}^{t} \xi(s) \mathrm{d} s=\sum_{k=0}^{\eta(t)} \xi_{k}+\int_{\tau[\eta(t)]}^{t} \xi(s) \mathrm{d} s \quad\left(\xi_{0}=0\right) .
$$

This clearly implies that the sum in equation 2 represents an approximation of the actual traveled distance. From the relation of equation 13, it easily follows that (see fig. 3) 


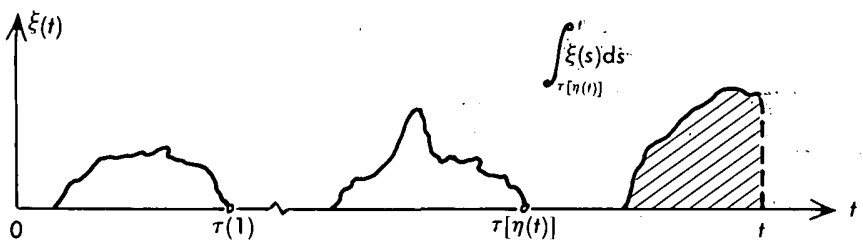

Figure 3.-Sample function of the process $\xi(t)$.

$$
\sum_{k=0}^{\eta(t)} \xi_{k} \leq \int_{0}^{t} \xi(s) \mathrm{d} s<\sum_{k=1}^{\eta(t)+1} \xi_{k}
$$

The inequality (eq. 14) is very important because, although we do not know how to determine the distribution function

$$
P\left[\int_{0}^{t} \xi(s) \mathrm{d} s \leq x\right]
$$

the distribution functions of the sums in equation 14 are readily available. The distribution of $\sum_{0}^{\eta(t)} \xi_{i}$ is given by equation 9 . The distribution of

$$
F_{t}{ }^{*}(x)=P\left(\sum_{k=1}^{\eta(t)+1} \xi_{k} \leq x\right)
$$

can be determined in the same way as $F_{t}(x)$. After a simple transformation we have

$$
F_{t}^{*}(x)=\sum_{n=0}^{\infty} \sum_{k=n+1}^{\infty} P\left(E_{n}{ }^{t}\right) P\left(G_{k}^{x}\right)
$$

On the basis of equation 14, it follows that

$$
F_{t}(x) \supseteq P\left[\int_{0}^{t} \xi(s) \mathrm{d} s \leq x\right] \supseteq F_{t}^{*}(x) .
$$

In figure 4, a graphical presentation of the inequalities (eq. 14) is given. Finally; by use of equation 16, we have

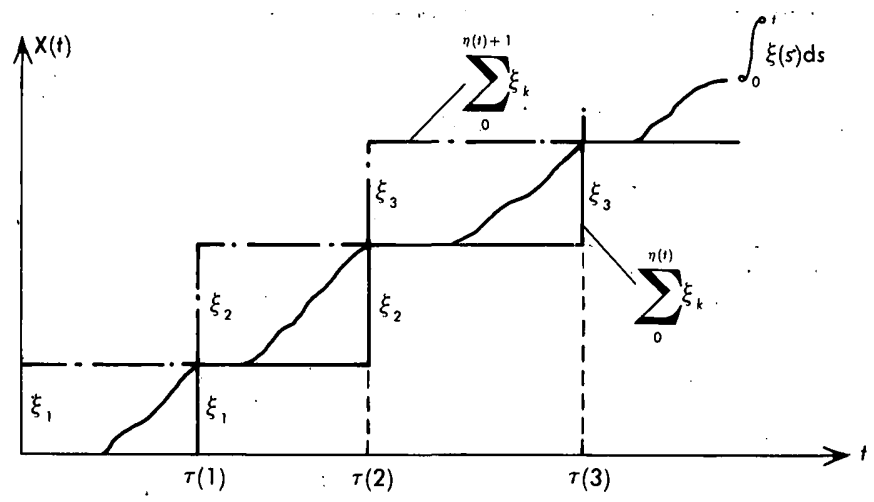

Figure 4.-Sample functions of the processes $\sum_{0}^{\eta(t)} \xi_{k}, \sum_{0}^{\eta(t)+1} \xi_{k}$,

$$
\text { and } \int_{0}^{t} \xi(s) \mathrm{d} s
$$

$$
\begin{gathered}
\max \left\{F_{t}(x)-P\left[\int_{0}^{t} \xi(s) \mathrm{d} s \leq x\right], P\left[\int_{0}^{t} \xi(s) \mathrm{d} s \leq x\right]-\right. \\
\left.F_{t}^{*}(x)\right\} \leq F_{t}(x)-F_{t}{ }^{*}(x)=\sum_{n=0}^{\infty} P\left(E_{n}{ }^{t}\right) P\left(G_{n}{ }^{x}\right) .
\end{gathered}
$$

\section{ASYMPTOTIC PROPERTIES OF THE MODELS}

On the basis of the previous analysis it follows that not the sum (eq. 2) but the integral $\int_{0}^{t} \xi(s) \mathrm{d} s$ represents the exact distance traveled by the particle at time $t$. Unfortunately, to our knowledge, the distribution function of the stochastic integral is not available. However, as we have seen, the distribution functions of the boundary sums in equation 14 are known and (provided certain regularity conditions hold) can be easily computed.

With regard to the inequality (eq. 16), either $F_{t}(x)$. or $F_{t}{ }^{*}(x)$ can be used as an approximation of $P\left[\int_{0}^{t} \xi(s) \mathrm{d} s<x\right]$. This immediately raises two questions: (1) Which of these two distributions represents the better approximation? (2) What error do we make utilizing either of these approximations?

An answer to the first question may be obtained from figure 4 . It seems to us that the sum (eq. 2) approximates better the stochastic integral (eq. 13) than the sum $\sum_{0}^{\eta(t)+1} \xi_{k}$ because for most applications, a particle will spend more time at rest than in movement. The answer to the second question is contained in the inequality of equation 17 .

In what follows we shall determine the error in Einstein's equation and investigate its asymptotic behavior as $t \rightarrow \infty$. To this end, notice that for every $x \supseteq 0$

$P[\mu(x)=\nu]=P\left(G_{\nu}{ }^{x}\right)$ and $P[\mu(x) \supseteq n]=P\left(\sum_{1}^{n} \xi_{\nu} \leqslant x\right)$.

From this and equation 8 , we have

$$
\begin{aligned}
& P[\mu(x) n]=P\left(\sum_{1}^{n} \xi_{\nu} \leqslant x\right)-P\left(\sum_{1}^{n+1} \xi_{\nu} \leqslant x\right) \\
& =\frac{\lambda_{2}{ }^{n}}{\Gamma(n)} \int_{0}^{x} u^{n-1} \mathrm{e}^{-\lambda_{2} u} \mathrm{~d} u-\frac{\lambda_{2}{ }^{n+1}}{\Gamma(n+1)} \int_{0}^{x} u^{n} \mathrm{e}^{-\lambda_{2} u} \mathrm{~d} u .
\end{aligned}
$$

Because

$$
\frac{\lambda_{2}{ }^{n}}{\Gamma(n)} \int_{0}^{x} u^{n-1} \mathrm{e}^{-\lambda_{2} u} \mathrm{~d} u=1-\mathrm{e}^{-\lambda_{2} x} \sum_{\nu=0}^{n-1} \frac{\left(\lambda_{2} x\right)^{\nu}}{\nu !}
$$

it follows that $P\left(G_{n}{ }^{x}\right)=\mathrm{e}^{-\lambda_{2} x} \frac{\left(\lambda_{2} x\right)^{n}}{n !}$. 
We are now in position to evaluate the sum (eq. 17). On the basis of equations 6 and 18, we have

$$
\sum_{n=0}^{\infty} P\left(E_{n}{ }^{t}\right) P\left(G_{n}{ }^{x}\right)=\mathrm{e}^{-\left(\lambda_{1} t+\lambda_{2} x\right)} \sum_{n=0}^{\infty} \frac{\left(\lambda_{1} t\right)^{n}}{n !} \frac{\left(\lambda_{2} x\right)^{n}}{n !}
$$

and by virtue of Holder's inequality (Loève, 1960) it follows that

$\sum_{n=0}^{\infty} \frac{\left(\lambda_{1} t\right)^{n}}{n !} \frac{\left(\lambda_{2} x\right)^{n}}{n !} \leqslant\left[\sum_{n=0}^{\infty} \frac{\left(\lambda_{1} t\right)^{2 n}}{(n !)^{2}}\right]^{1 / 2}\left[\sum_{n=0}^{\infty} \frac{\left(\lambda_{2} x\right)^{2 n}}{(n !)^{2}}\right]^{1 / 2}$ $=\left[\begin{array}{lll}I_{0}\left(2 \lambda_{1} t\right) & I_{0} & \left(2 \lambda_{2} x\right)\end{array}\right]^{1 / 2}$.

Therefore, if $t$ is large enough,

$$
\begin{aligned}
\sum_{n=0}^{\infty} P\left(E_{n}{ }^{t}\right) P\left(G_{n}{ }^{x}\right) \leqslant & \mathrm{e}^{-\left(\lambda_{1} t+\lambda_{2} x\right)}\left[I_{0}\left(2 \lambda_{1} t\right) I_{0}\left(2 \lambda_{2} x\right)\right]^{1 / 2} \\
& \leq \mathrm{e}^{-\lambda_{1} t}\left[I_{0}\left(2 \lambda_{1} t\right)\right]^{1 / 2} \approx \frac{1}{\left(4 \pi \lambda_{1} t\right)^{1 / 4}}
\end{aligned}
$$

because for large $t, I_{0}\left(2 \lambda_{1} t\right) \approx \mathrm{e}^{2 \lambda_{1} t}\left(4 \pi \lambda_{1} t\right)^{1 / 4}$. Hence,

$$
\begin{aligned}
& \max \left\{F_{t}(x)-P\left[\int_{0}^{t} \xi(s) \mathrm{d} s \leq x\right], P\left[\int_{0}^{t} \xi(s) \mathrm{d} s \leq x\right]\right. \\
&\left.-F_{t}^{*}(x)\right\}<\frac{1}{\left(4 \pi \lambda_{1} t\right)^{1 / 4}} \rightarrow 0
\end{aligned}
$$

as $t \rightarrow \infty$ uniformly with respect to $x$.

Before we conclude this section, we shall investigate the asymptotic behavior of the distribution function (properly normalized and centralized) of $\sum_{0}^{\eta(t)} \xi_{k}$ as $t \rightarrow \infty$. Here we assume that $\left[\xi_{k}\right]_{1}^{\infty}$ is independent, identically distributed, independent of $\eta(t)$, and $\eta(t) \rightarrow \infty$ in probability as $t \rightarrow \infty$. If

$$
0<\operatorname{var}\left(\xi_{k}\right)=\dot{\sigma}^{2}<\infty \text { and } \alpha=E\left(\xi_{k}\right)
$$

then the simplest case of the central limit theorem asserts that

$$
P\left(X_{n} \leq x \sigma \sqrt{n}+n \alpha\right) \rightarrow \frac{1}{\sqrt{2 \pi}} \int_{-\infty}^{x} \mathrm{e}^{-1 / 2 u^{2}} \mathrm{~d} u
$$

as $\mathrm{n} \rightarrow \infty$, where $X_{n}=\sum_{k=1}^{n} \xi_{n}$.

$$
\text { Consider } \begin{aligned}
P\left[\sum_{0}^{\eta(t)} \xi_{k}\right. & \leq x \sigma \sqrt{\eta(t)}+\alpha \eta(t)] \\
= & \sum_{n=0}^{\infty} P\left[\sum_{0}^{n} \xi_{k} \leq x \sigma \sqrt{n}+\alpha n, \eta(t)=n\right] \\
& =\sum_{n=0}^{\infty} P\left(X_{n} \leq x \sigma \sqrt{n}+\alpha n\right) P\left(E_{n}{ }^{t}\right) .
\end{aligned}
$$

From this and the Toeplitz lemma (Hardy, 1949, p. 49) it follows that

$$
\begin{aligned}
& \lim _{t \rightarrow \infty} P\left[\sum_{0}^{\eta(t)} \xi_{k} \leqslant x \sigma \sqrt{\eta(t)}+\alpha \eta(t)\right] \\
& \quad=\lim _{n \rightarrow \infty} P\left(X_{n} \leq x \sigma \sqrt{n}+n \alpha\right)=\frac{1}{\sqrt{2 \pi}} \int_{-\infty}^{x} \mathrm{e}^{-1 / 2 u^{2}} \mathrm{~d} u .
\end{aligned}
$$

\section{ANALYSIS OF PARAMETERS IN EINSTEIN MODEL}

As we have already seen, Einstein's assumptions imply the relations of equation 7 and equation 18 . On the basis of this, we have

$$
F_{t}(x)=\exp \left[-\left(\lambda_{1} t+\lambda_{2} x\right)\right] \sum_{n=0}^{\infty} \sum_{k=n}^{\infty} \frac{\left(\lambda_{1} t\right)^{n}}{n !} \frac{\left(\lambda_{2} x\right)^{k}}{k !}
$$

and $F_{t}{ }^{*}(x)=\exp \left[-\left(\lambda_{1} t+\lambda_{2} x\right)\right] \sum_{n=0}^{\infty} \sum_{k=n+1}^{\infty} \frac{\left(\lambda_{1} t\right)^{n}}{n !} \frac{\left(\lambda_{2} x\right)^{k}}{k !}$.

Both distribution functions depend on the same two parameters $\lambda_{1}$ and $\lambda_{2}$, which on the other hand depend on the hydraulic conditions and properties of the particle. Clearly, $F_{t}(x)$ and $F_{t}{ }^{*}(x)$ are completely specified if values $\lambda_{1}$ and $\lambda_{2}$ are given.

To develop a method for evaluation of $\lambda_{1}$ and $\lambda_{2}$ using experimental data, it is necessary to determine relations between these two parameters and those parameters of the distribution functions that can be estimated with the highest possible accuracy. To this end, denote by $m(t)$ and $m^{*}(t)$ the mathematical expectation corresponding to $F_{t}(x)$ and $F_{t}{ }^{*}(x)$ respectively; then we have (see for example Todorovic, 1970)

$$
\begin{aligned}
m(t) & =E\left(\sum_{0}^{\eta(t)} \xi_{\nu}\right)=E[\eta(t)] E\left(\xi_{1}\right) \\
m^{*}(t) & =E\left(\sum_{1}^{\eta(t)+1} \xi_{\nu}\right)=E[\eta(t)+1] E\left(\xi_{1}\right) .
\end{aligned}
$$

On the basis of this and equations 5 and 6 , it follows that

$$
m(t)=\frac{\lambda_{1}}{\lambda_{3}} t \text { and } m^{*}(t)=\frac{\lambda_{1}}{\lambda_{2}} t+\frac{1}{\lambda_{2}} .
$$

In the same way one can show that

$$
V(t)=2 \frac{\lambda_{1}}{\lambda_{2}{ }^{2}} t \text { and } V^{*}(t)=2 \frac{\lambda_{1}}{\lambda_{2}{ }^{2}} t+\frac{1}{\lambda_{2}{ }^{2}}
$$

where $V(t)=\operatorname{var}\left(\sum_{0}^{\eta(t)} \xi_{\nu}\right)$ and $V^{*}(t)=\operatorname{var}\left(\sum_{1}^{\eta(t)+1} \xi_{\nu}\right)$.

From equations 14 and 22 , it follows that

$$
\frac{\lambda_{1}}{\lambda_{2}} t \leq \int_{0}^{t} E[\xi(s)] \mathrm{d} s<\frac{\lambda_{1}}{\lambda_{2}} t+\frac{1}{\lambda_{2}} .
$$

Taking into account the equality in equation 13, it follows, after a simple analysis, that we have a situation as presented in figure 5. This follows from equation 13 because

$$
\int_{0}^{t} E[\xi(s)] \mathrm{d} s=\frac{\lambda_{1}}{\lambda_{2}} t+E\left\{\int_{\tau[\eta(t)]}^{t} \xi(s) \mathrm{d} s\right\} .
$$




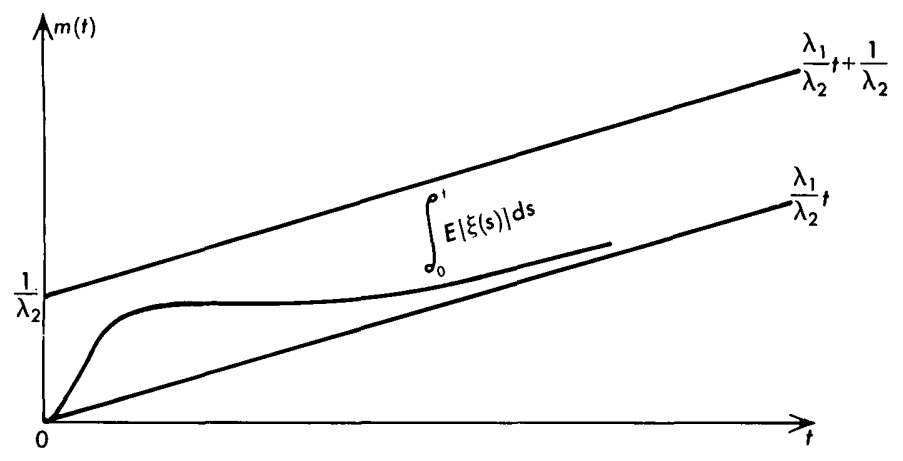

Figure 5.-Actual and approximate average traveled distances.

The second term on the right side of this relation is less than or equal to $1 / \lambda_{2}$. Equation 25 also implies that the average velocity of the particle is approximately $\lambda_{1} / \lambda_{2}$.

\section{SUMMARY}

The subject matter of interest in this paper is the movement of sediment particles. Since 1937 when H. A. Einstein developed the first stochastic model to describe longitudinal movement of such a particle, the problem area of sediment transport and dispersion has been a source of continuing interest and disagreement.

Distinguished from a Newtonian particle (that is, one where, given the present state, the future states are uniquely determined) the law of motion of a sediment particle is stochastic in the sense that only probabilities of the future states can be determined (for instance, given that at the time $t=0$ the particle was at the point $x=0$, at time $t>0$ it will be in an interval $[x, x+\Delta x]$ with probability $\left.F_{t}(x+\Delta x)-F_{t}(x)\right)$.

In this paper, a unified treatment of various approaches has been. achieved by noticing that the basic model underlying all these approaches is that of a random walk on the line defined by equation 2 . The differences among models were results of different assumptions concerning $\xi_{\nu}$ and $\eta(t)$ of this process. Because, in obtaining the distribution function (eq. 9), the only requirement was independence $\left[\xi_{k}\right]_{1}^{\infty}$ and $\eta(t)$, equation 9 represents the most general solution of the problem.

It is of interest to point out that being discontinuous at $x=0$, the distribution function $F_{t}(x)$ is not differ- entiable and the corresponding density function cannot be obtained by formal differentiation of $F_{t}(x)$. Failing to notice this fact, a number of authors have wondered why the area under the "density function" was less than 1 . We conclude this comment on the models by the remark that equation 10 relates Lagrangian and Eulerian approaches.

It follows from equation 13 that the stochastic process (eq. 2) represents only an approximation of the actual motion of the particle. (If the steps of the particle were executed instantly, then equation 2 would be the exact traveled distance.) Inequalities of equation 14 offer an evaluation of the error. (See also fig. 4.)

The following facts with respect to asymptotic properties of the modei have been established: First, the relative error made by utilizing the process of equation 2 instead of equation 13, at least in the Einstein model, tends to zero as $t \rightarrow \infty$ uniformly with respect to $x$. Second, assuming only that $\left[\xi_{k}\right]_{1}^{\infty}$ is a sequence of independent identically distributed random variables, the distribution function $F_{t}(x)$, properly normalized and centralized, tends to a normal distribution as $t \rightarrow \infty$. The same holds for $F_{t}^{*}(x)$.

Finally, some relations between parameters of the distributions $F_{t}(x)$ and $F_{t}{ }^{*}(x)$ and parameters $\lambda_{1}, \lambda_{2}$ are established in equations 22 and 23.

\section{REFERENCES CITED}

Crickmore, M. J., and Lean, G. H., 1962, The measurement of sand transport by means of radioactive tracers: Royal Soc. [London] Proc., ser. A, v. 266, p. 402-421.

Einstein, H. A., 1937, Der Gescheibetrieb als Wahrscheinlichkeitsproblem: Zurich, Verlag Rascher and Co., 111 p.

Hardy, G. H., 1949, Divergent series: Oxford, Oxford University Press, 396 p.

Hubbell, D. W., and Sayre, W. W., 1964, Sand transport studies with radioactive tracers: Am. Soc. Civil Engineers Proc., v. 90, HY3, p. 39-68.

Loève, Michel, 1960, Probability theory: Princeton, D. Van Nostrand, 685 p.

Skorokhod, A. V., 1965, Studies in the theory of random processes: Reading, Mass., Addison-Wesley, $199 \mathrm{p}$.

Todorovic, Petar, 1967, A stochastic process of monotonous sample functions: Matem. Vesnik 4(19), p. 149-158.

- 1970, On some problems involving random number of random variables: Annals of Math. Statistics, v. 41, no. 3, p. 1059-1063. 
Jour Research U.S. Geol. Survey

Vol. 3, No. 5, Sept.-Oct. 1975, p. 519-528

\title{
GEOLOGY OF PORCUPINE MOUNTAINS IN CARP RIVER AND WHITE PINE QUADRANGLES, MICHIGAN
}

\author{
By HAROLD A. HUBBARD, Reston, Va.
}

\begin{abstract}
The Porcupine Mountains are the eroded remnants of the upper limb of an anticline that is faulted along most of its southern, overturned, limb. The exposed rocks include about $5,000 \mathrm{ft}(1,525 \mathrm{~m})$ of middle Keweenawan intermediate to mafic lava flows interbedded with subordinate lithic sedimentary rocks and also include about $3,000 \mathrm{ft}(915 \mathrm{~m})$ of overlying middle and upper Keweenawan sedimentary rocks. The sediments are derived from lower Keweenawan and older rocks. The structural relief is at least $8,000 \mathrm{ft}(2,440 \mathrm{~m})$ between the crest of the Porcupine Mountains anticline and the trough of the Iron River syncline about $5 \mathrm{mi}(8 \mathrm{~km})$ to the south. The reverse fault along the southern, overturned, limb of the anticline has a displacement of about $5,000 \mathrm{ft}$ $(1,525 \mathrm{~m})$.
\end{abstract}

Porcupine Mountains State Park, comprising more than 58,000 acres (23,000 ha), is the largest of Michigan's parks. It is in the western part of the upper or northern peninsula of Michigan, about $17 \mathrm{mi}(27 \mathrm{~km})$ west of the village of Ontonagon (fig. 1). The park is one of the few wilderness areas in the Midwest; although most of the area has been logged, several square miles of virgin timber remain. About $80 \mathrm{mi}$ $(130 \mathrm{~km})$ of trails are maintained by the Michigan Department of Natural Resources.

The area mapped, shown in figure 2, is about 55 $\mathrm{mi}^{2}$, wholly within the park, and is bounded on the south by lat $46^{\circ} 45^{\prime} \mathrm{N}$., on the east by long. $89^{\circ} 37^{\prime} \mathrm{W}$., and on the north and west by Lake Superior. It includes the parts of the Carp River and White Pine 15-minute quadrangles north and west of the South Boundary Road. The investigation was done in cooperation with the Geological Survey Division of the Michigan Department of Natural Resources.

\section{PREVIOUS WORK}

Parts of the Porcupine Mountains have been mapped by several geologists, most of whom have interpreted the volcanic rocks as lava flows and the structure as an anticline; a few, however, have interpreted the felsite flows as intrusive rocks and the anticline as a laccolithic dome: The first extensive geologic examina- tion of the area was made by R. D. Irving's assistants, W. M. Chauvenet, A. C. Campbell, B. N. White, and R. McKinlay. Using their notes and samples, Irving (1883, p. 206-225) described the major features of the structure and stratigraphy. Wright (1905, p. 35-44) mapped the distribution of the bedrock in more detail and also described some of the glacial deposits. Butler and Burbank (1929, p. 169-170), on the basis of limited field work south and east of the mountains, interpreted the felsite as an intrusive rock and the structure as a laccolith. Thaden (1950) interpreted the felsite as a series of flows arched into an anticline. Meshref and Hinze (1970, pl. 2), ' in a geophysical paper, considered the felsite as an intrusive rock. Chaudhuri and Faure (1967) dated the felsite at $1,042 \pm 32$ m.y.

The stratigraphic nomenclature used in this paper is based on studies by White and Wright (1960) and on unpublished mapping by the authors of White and others (1971). Table 1 correlates the nomenclature used herein with that of earlier writers.

\section{GENERAL GEOLOGY}

The rocks exposed in Porcupine Mountains are part of the upper limb of an anticline. Although it is not obvious from exposures, the southern limb probably is overturned. A reverse fault having at least 5,000 ft $(1,525 \mathrm{~m})$ displacement is nearly parallel to and about $2 \mathrm{mi}(3 \mathrm{~km})$ south of the fold axis. The bedrock units include lava flows, sedimentary rocks, and small bodies of mafic intrusive rocks; they are assigned to the unnamed formation of Johnson and White (1969), the Copper Harbor Conglomerate, and the Nonesuch Formation, all of Keweenawan age. These rocks are part of a continuous sequence of interbedded sedimentary and volcanic rocks. The thickness of the rocks exposed in the area is more than $8,000 \mathrm{ft}(2,440$ $\mathrm{m})$. Glacial deposits almost completely cover the area. They are less than $20 \mathrm{ft}(6 \mathrm{~m})$ thick where dissected by streams on the slopes of the upland and are.thinner on the small hills of the upland where many bold outcrops occur on steep slopes. 


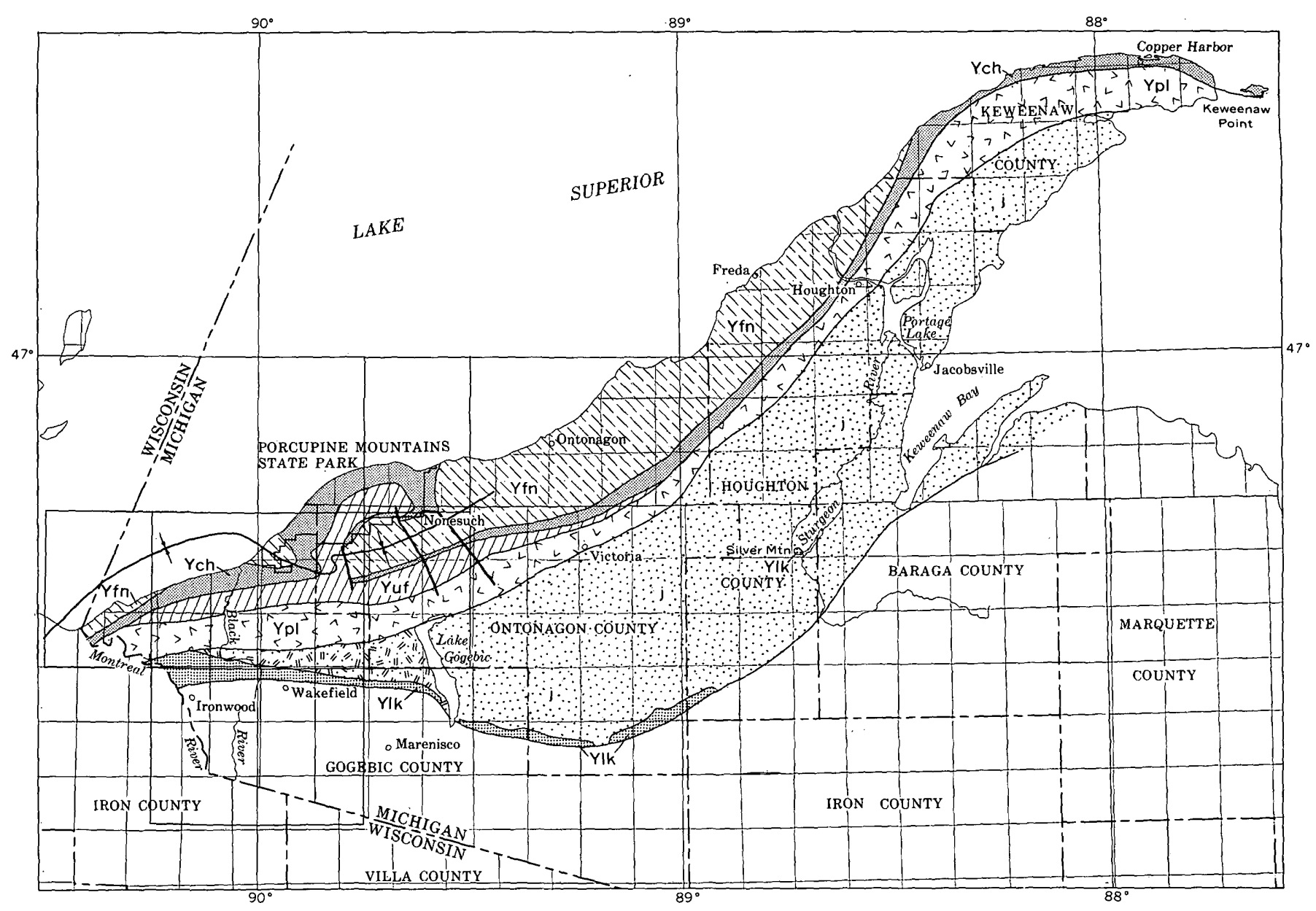

EXPLANATION
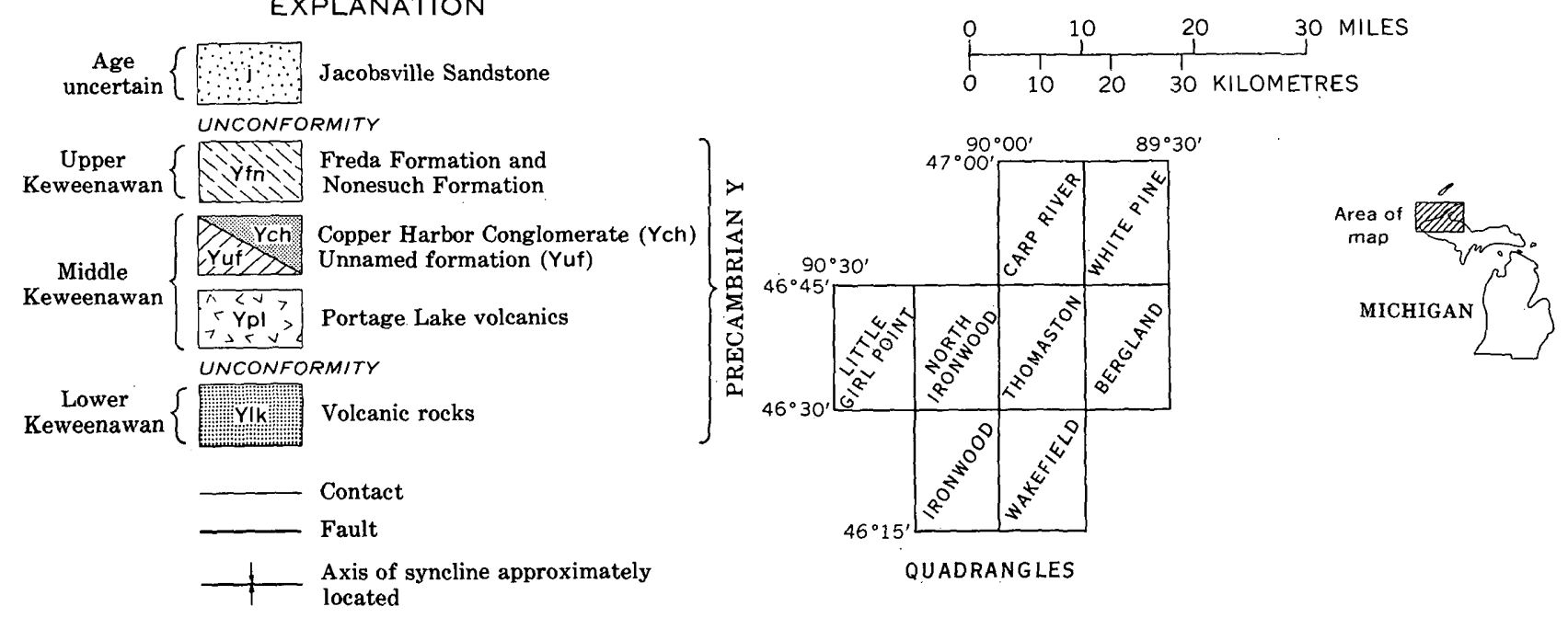

Figure 1.-Generalized geologic map of the Keweenawan rocks of Michigan, south of Lake Superior (modified from White, 1972). 


\section{UNNAMED FORMATION}

The unnamed formation is a sequence of subaerially deposited andesite, felsite, and quartz-porphyry lava flows interbedded with volcaniclastic lithic sandstone, siltstone, and conglomerate. The unnamed formation forms the knobby upland of the Porcupine Mountains. Regionally, the formation is a volcanic pile; the maximum thickness measurable at the surface is about $8,000 \mathrm{ft}(2,440 \mathrm{~m})$ in the Bergland and Thomaston quadrangles about $5 \mathrm{mi}(8 \mathrm{~km})$ south of the park. It wedges out in the Greenland quadrangle to the east and in the Little Girl Point quadrangle to the west. Only the upper $2,500 \mathrm{ft}(765 \mathrm{~m})$ of the formation is exposed in the Porcupine Mountain State Park.

The unnamed formation is conformable with the underlying Portage Lake Volcanics and is distinguishable from it by differences in rock type. The mafic volcanic rocks of the Portage Lake are predominantly basalts, whereas those of the unnamed formation are predominantly andesites. The rocks of the unnamed formation are finer grained and contain a greater proportion of porphyritic and felsic rocks than do those of the unnamed formation. The formation was first recognized by Johnson and White (1969, p. 5-8), near Oak Bluff in the Matchwood quadrangle $18 \mathrm{mi}$ $(29 \mathrm{~km})$ to the east, but they have not yet named it formally.

Most outcrops of the formation occur where streams have cut through the mantle of glacial deposits. Exposures of the felsite that underlies most of the knobby upland are most common on the steep slopes of the knobs.

Most of the andesite flows are less than $25 \mathrm{ft}(8 \mathrm{~m})$ thick and have pahoehoe tops, but some have autobrecciated tops. Flow tops generally contain sparse irregular vesicles filled with chlorite, epidote, quartz, and calcite. The rocks are fine grained, medium dark gray, grayish purple, greenish gray, and grayish red. Most are porphyritic, and contain sparse andesine phenocrysts generally less than $2 \mathrm{~mm}$ long. Thin section study shows the rocks have trachytic to felted texture. The rocks contain 50-66 percent oligoclase, either no visible pyroxene or $8-20$ percent clinopyroxene, and 10-30 percent opaque minerals including ilmenite (altered in part to leucoxene), hematite, and magnetite. A few flows contain sparse pseudomorphs after olivine. The feldspars are cloudy and contain epidote and fine-grained alteration minerals not determinable by optical methods. The pyroxenes are broken and have patchy twinning. The groundmass is nearly opaque and the minerals cannot be determined by optical methods.

An aphanitic felsite lava flow underlies the knobby upland around Mirror and Lost Lakes. Although the flow may be no more than $500 \mathrm{ft}(155 \mathrm{~m})$ thick, the outcrop belt is about $2.5 \mathrm{mi}(4 \mathrm{~km})$ wide because the flow occurs across the crest of the Porcupine Mountain anticline. Nowhere does a completely exposed section of the flow crop out, so the felsite could be two or more flows of the same rock type; no features were seen, however, to suggest that more than one flow is present.

The upper part of the felsite flow is exposed in many places; the lower part is exposed only in the southernmost part of the area (secs. 3, 4, and 5, T. 50 N., R. $43 \mathrm{~W}$, and in the valley of Lost Creek, sec. 31, T. 51 N., R. 42 W.). Massive rock forms the lower part of the flow and is interspersed with vesicular rock in the upper part, although few exposures contain more than a third vesicular rock in the upper part, massive rock predominates in exposures because it is more resistant to weathering and erosion than the vesicular rock. On lichen-covered surfaces the massive and vesicular rocks cannot be distinguished, but on clean surfaces the vesicular rock is readily distinguished from the massive rock because of color difference. The vesicular rock is grayish pink; the massive rock is pale purple to grayish purple or grayish-red purple in the upper part of the flow and grayish purple to grayish red to moderate-reddish brown in the lower part.

Vesicular felsite occurs in light-colored irregular to disk-shaped small masses in a matrix of dark massive rock and as narrow layers separated by wider layers of massive rock. In a few places vesicular felsite forms whole outcrops; most is in irregular to disk-shaped masses that range from less than $3 \mathrm{~mm}$ to about 15 $\mathrm{cm}$ across. The large masses are usually platy or diskshaped and more or less alined, giving a poorly layered to well-layered appearance to the rock. In many places the vesicular. rock was greatly stretched and compressed; the porosity was lost, and the rock now consists of alternating layers of grayish-red and light-red felsite. Few of the light bands are more than $5 \mathrm{~mm}$ thick and most are less than $3 \mathrm{~mm}$ thick. Light-colored layers are a few inches to a few feet long, and the layers overlap; consequently, in many places layered rock breaks into plates several square centimetres in area and less than a centimetre thick. The layers of rock are folded, fold axes a few metres apart vary greatly in orientation. Conspicuously layered rock is interlayered with vesicular rock in many places; layered rock is abundant in the central part of the area, east and southeast of Mirror Lake and Government Peak. An exceptionally good exposure of it occurs on Inlet Creek near Trap Falls (NW1/4 sec. 30, T. 51 N., R. 42 W.). Lithophysae 

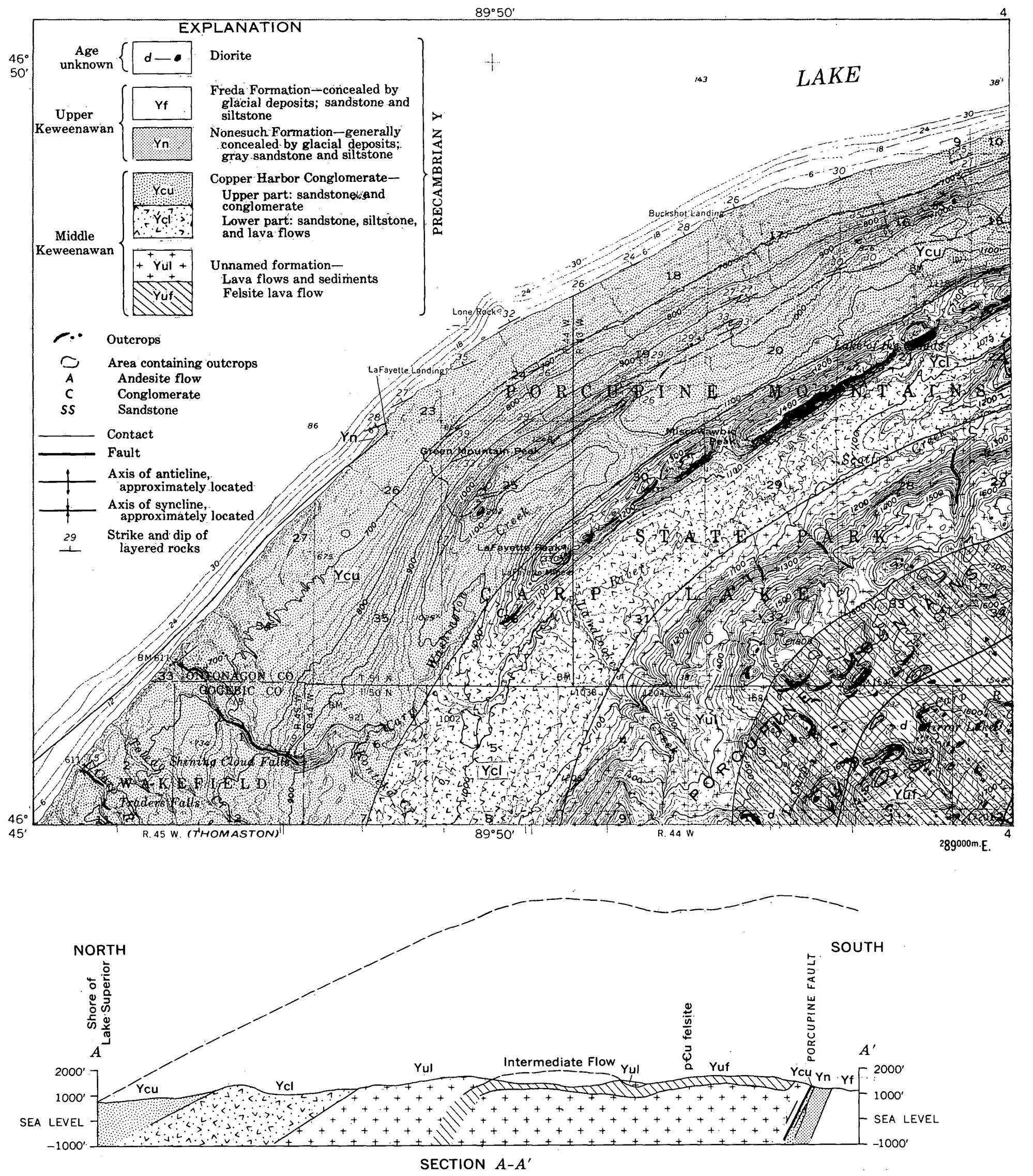

Figure 2.-Bedrock geologic map and sections of Porcupine Mountains, Mich. Geology by H. A. Hubbard: in 1970 and. 1971; geology and geology: in secs: 27 " and $: 34, T .51$. N., R. "42 W:; by "W: S. White in 1971. Base 

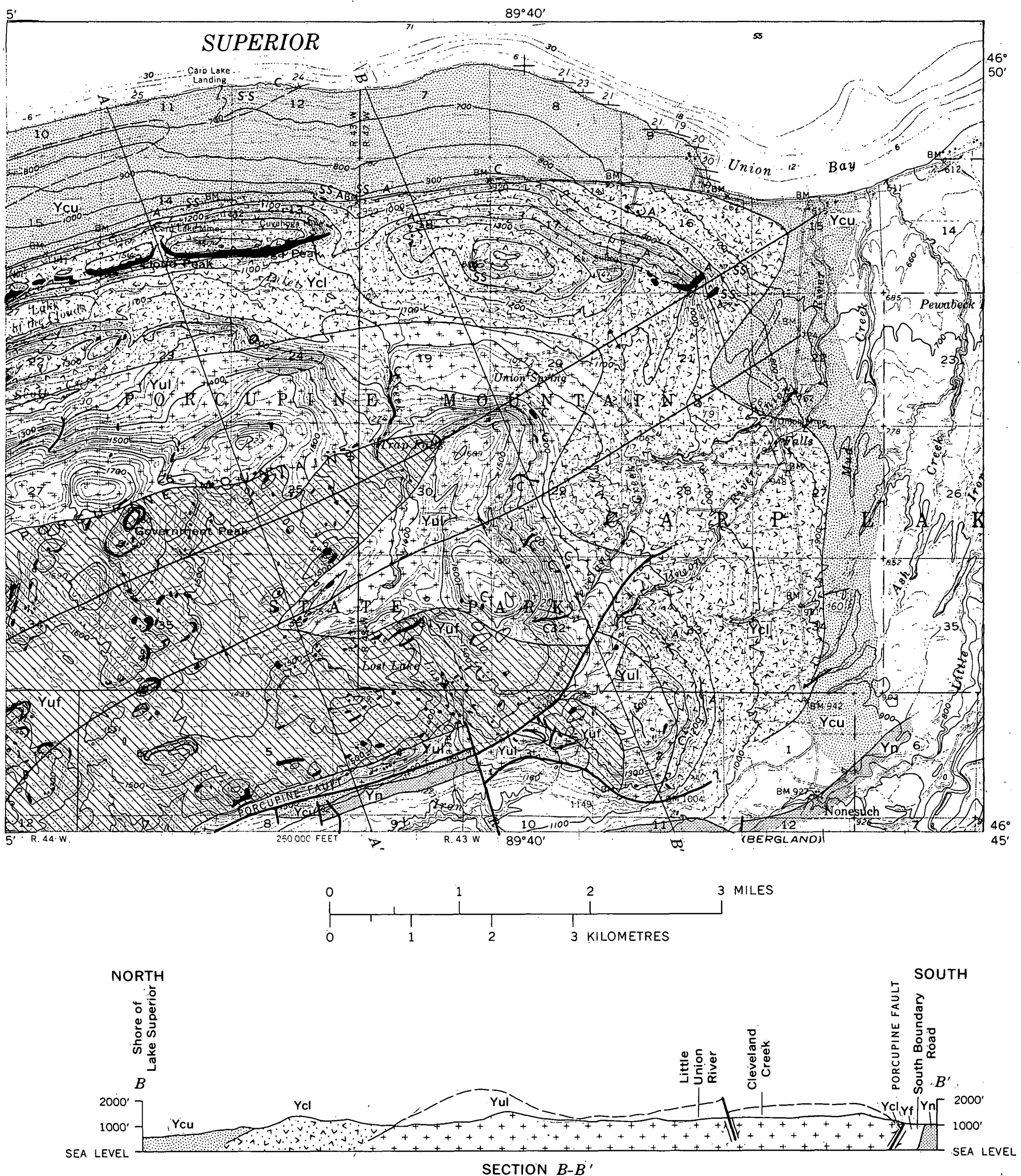

along shore of Lake Superior by White and Wright (1960); geology of Nonesuch Formation in southeast from Butler and Burbank (1929); from ,U.S.: Geological Survey, White" Pine and Càn River '15-minute quadrangles, 1956." 
TABLe 1.-Correlation of stratigraphic names used in the Porcupine Mountains, Mich.

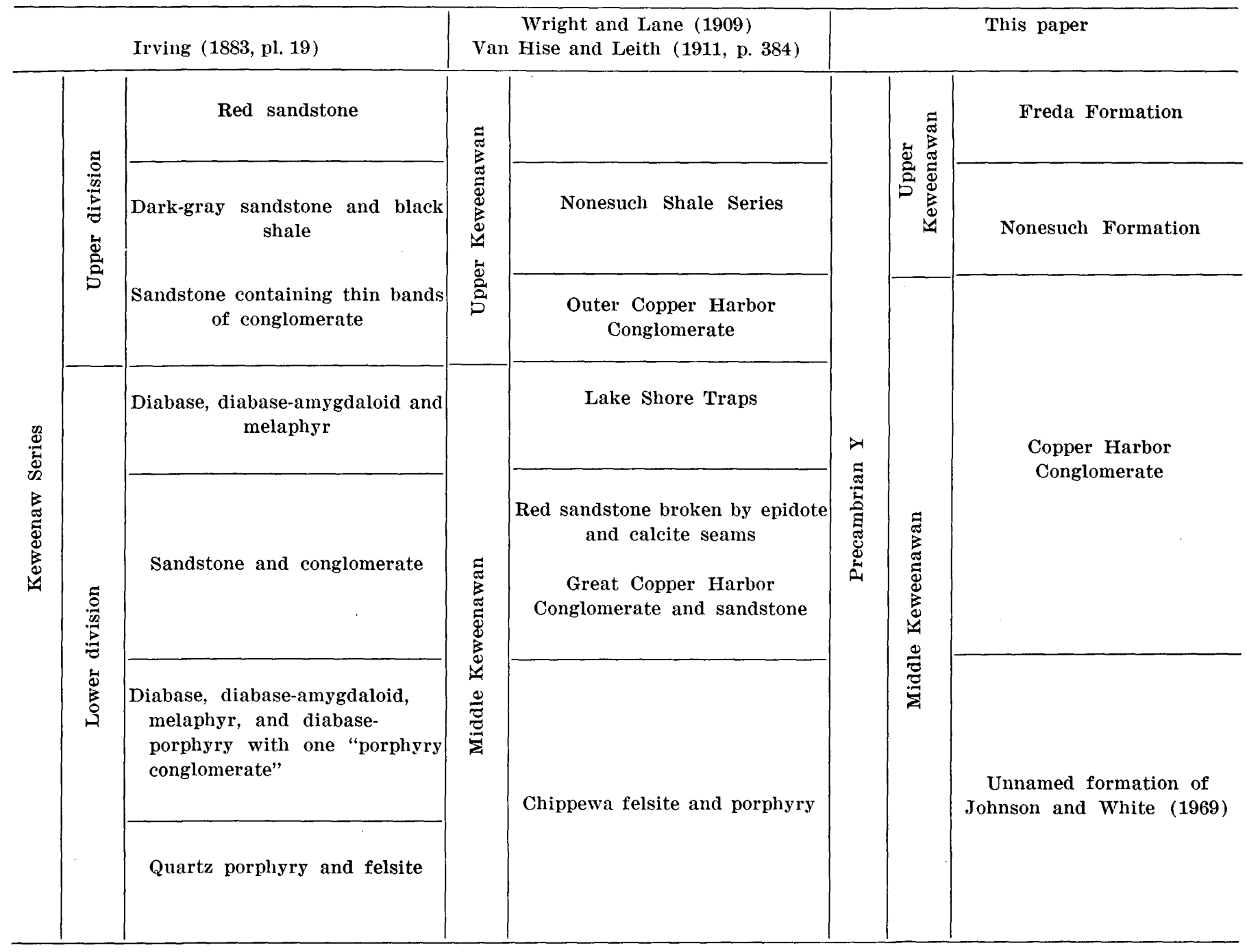

are well developed near the center of sec. 34, T. $51 \mathrm{~N}$., R. $43 \mathrm{~W}$.

The felsite contains very sparse quartz phenocrysts -in a devitrified cryptocrystalline matrix; the phenocrysts show evidence of partial resorption and are less than $0.2 \mathrm{~mm}$ across. Epidote pseudomorphs of prismatic crystals were observed in a few thin sections. Secondary quartz is abundant; it fills vesicles and forms many tiny veinlets. Some quartz in vesicles is pseudomorphic after platy crystals of tridymite.

A pale-red to moderate-reddish-brown quartz latite flow at the top of the unnamed formation crops out in three places within the area (in sec. $24, T$. 51 N., R. 43 W.; sec. 32 , T. 51 N., R. 43 W.; and sec. 2 , T. 50 N., R. 43 W.) and also in the Thomaston quadrangle to the south of the study area. The rock ranges from uniformly massive rock to rock containing sparse to abundant patches of compressed pumice. 'The flow resembles quartz latite flows in the Ironwood area to the west. Sparse broken feldspar phenocrysts generally about $2 \mathrm{~mm}$ across and rarely as large as $5 \mathrm{~mm}$ across are contained in the rock, as are sparse rounded quartz phenocrysts, commonly about $1 \mathrm{~mm}$ across.

The sedimentary rocks of the unnamed formation are similar to the coarser grained rocks of the overlying Copper Harbor Conglomerate, but the former contain more matrix and volcanic debris. Most of the exposed sedimentary rock is sandy conglomerate, usually containing pebbles and cobbles less than $10 \mathrm{~cm}$ across. Angular to subrounded boulders $3 \mathrm{ft}(1 \mathrm{~m})$ across occur in exposures in sec. 20 and north of sec. 29, T. 51 N., R. 42 W.

\section{COPPER HARBOR CONGLOMERATE}

The Copper Harbor Conglomerate in the Porcupine Mountains is composed predominantly of sandstone and siltstone and subordinate beds of conglomerate. Lava flows occur in the lower part. The Copper Harbor 
Conglomerate was named by Lane and Seaman (1907) for exposures near Copper Harbor, about $80 \mathrm{mi}(130$ $\mathrm{km}$ ) northeast of the Porcupine Mountains. They divided it into three members: The Great Conglomerate, the Lake Shore Traps, and the Outer Conglomerate. In the Porcupine Mountains, the lava flows north of the Lake of the Clouds were called the Lake Shore Traps by Wright and Lane (1909), by analogy with lava flows at Keweenaw Point. White and Wright (1960, fig. 3.2) showed that the Lake Shore Traps are not persistent and that the Outer and Great Conglomerates cannot be separated west of Portage Lake, about $60 \mathrm{mi}(95 \mathrm{~km})$ northeast of the Porcupine Mountains. Lake Shore Traps is not a useful term for the lava flows in the Porcupine Mountains because lava flows occur throughout the lower $2,800 \mathrm{ft}$ $(855 \mathrm{~m}$ ) of the formation. On the geologic map (fig. 2 ), the part of the formation containing lava flows is shown as lower Copper Harbor Conglomerate and the remainder is shown as upper Copper Harbor Conglomerate. The maximum thickness of the Copper Harbor Conglomerate in the Porcupine Mountains is about $5,000 \mathrm{ft}(1,525 \mathrm{~m})$ in the north part of the area; it thins southward and is as little as $500 \mathrm{ft}$ $(155 \mathrm{~m})$ thick about $8 \mathrm{mi}(13 \mathrm{~km})$ to the south (White, 1972, fig. 3).

The Copper Harbor Conglomerate underlies the lowland east of the mountains, the valley and ridge north of the knobby upland, and part of the lowland south of the mountains. Outcrops are common along the shore of Lake Superior and in some places on the ridge north of Lake of the Clouds; they are very sparse on the north slope of the knobby upland and are generally absent in low areas. The lava flows are poorly exposed except on the crest and south side of the ridge north of the Lake of the Clouds and locally on the ridge between Scott Creek and Lake of the Clouds in sec. 22, T. 51 N., R. 43 W.

Exposures in the region are not adequate to reveal whether the Copper Harbor Conglomerate is conformable with, interfingered with, or disconformable with the unnamed formation of Johnson and White (1969). The base of the Copper Harbor was placed at the top of the youngest quartz porphyry. Despite sparse exposures, this quartz porphyry is mappable in the White Pine, Carp River, and Thomaston quadrangles; it is not exposed to the west in the North Ironwood quadrangle where, if present, it occurs within a wide band having no exposures.

The Copper Harbor Conglomerate is a grayish-red lithic sandstone containing beds of lithic siltstone and conglomerate and six or more lava flows. Conglomerate is very subordinate in the Copper Harbor of the Porcupine Mountains; it is most abundant in the rocks above the uppermost flow but even here it probably forms less than 10 percent of the thickness. In contrast, in the Ironwood area to the west, conglomerate makes up more than three-quarters of the rock in the $2,000 \mathrm{ft}(610 \mathrm{~m})$ of section above the uppermost flow. Most of the sandstone is crossbedded. Lowangle crossbeds fill spoon-shaped scours that are generally $2-5 \mathrm{ft}(0.5-1.5 \mathrm{~m})$ across and less than 9 in. (23 $\mathrm{cm})$ deep. Some sandstone appears massive, but it generally parts into layers about $1 \mathrm{in} .(25 \mathrm{~mm})$ thick.

The sand of the Copper Harbor is angular or subangular, predominantly medium grained or finer, and moderately well sorted. The pebbles and cobbles are moderately well-rounded to very well rounded. Nearly all pebbles and cobbles are less than $8 \mathrm{~cm}$ in diameter, but cobbles $23 \mathrm{~cm}$ in diameter occur in a conglomerate bed near the mouth of the Big Carp River, sec. 33, T. 51 N., R. 44 W. Most conglomerate beds are less than $5 \mathrm{ft}(1.5 \mathrm{~m})$ thick, and some are only the thickness of a single pebble or cobble; the thickest is about $25 \mathrm{ft}(8 \mathrm{~m})$. The lithic sandstone, siltstone, and conglomerate are composed of rock fragments, quartz, feldspar, and small amounts of other minerals. The composition of the sediments varies with grain size, the relative proportion of quartz grains increasing as the grain size decreases. Quartz grains form less than 20 percent of the grains in medium-grained sandstone, but two-thirds or more of. the grains in siltstone. Plagioclase and less abundant microcline form 2-15 percent of the grains, these feldspars are somewhat more abundant in finer grained rocks. The rock fragments are predominantly intermediate and felsic volcanic rocks but also include metamorphic rocks. Epidote, amphibole, and chlorite occur but are not common. Matrix is abundant, but most of the matrix camnot be resolved by optical methods. Some quartz grains have secondary overgrowths of quartz. Calcite cement occurs in some places, and locally calcite forms veinlets and fills joints.

At least six lava flows are interbedded with the sediments. They range in thickness from about $15 \mathrm{ft}(4 \mathrm{~m})$ to about $70 \mathrm{ft}(21 \mathrm{~m})$. The rocks are fine grained, generally porphyritic, and black or brownish gray. The pahoehoe flow tops contain irregularly shaped vesicles, generally less than $6 \mathrm{~mm}$ across. The vesicles are concentrated in lenticular areas near the flow tops and are filled with chlorite, quartz, and epidote. The rocks are andesites, except one flow that is a basalt, and petrographically they resemble the flows of the unnamed formation.

The Copper Harbor Conglomerate is probably a fluviatile deposit derived from a highland to the south 
(White and Wright, 1960, p. B6). The volcanic detritus was probably derived from the lower Keweenawan volcanic rocks (Hubbard, 1972).

\section{NONESUCH FORMATION}

The Nonesuch Formation was named by Lane and Seaman (1907, p. 691). Irving (1883, p. 221-226) called these rocks the Nonesuch Shale, but because very fine to fine sandstone is more abundant than siltstone (the shale of Irving and many other writers), the name Nonesuch Formation is preferable. The Nonesuch crops out in sec. 26, T. 51 N., R. 44., within the area mapped and lies under Lake Superior north of the area. It has been penetrated in drill holes near the South Boundary Road and crops out along the Little Iron River near Nonesuch and along the Iron River about $2 \mathrm{mi}(3 \mathrm{~km})$ east of the area near Silver City (fig. 2).

The Nonesuch gradually thins from about $700 \mathrm{ft}$ $(215 \mathrm{~m})$ in thickness on Keweenaw Point, about 100 mi $(160 \mathrm{~km})$ east of the Ironwood area, to about $600 \mathrm{ft}(185 \mathrm{~m})$ thick near the Porcupine Mountains (White and Wright, 1966, p. 1171) and to about 250 $\mathrm{ft}(75 \mathrm{~m})$ thick on the Bad River, about $40 \mathrm{mi}(65 \mathrm{~km})$ to the west. The formation thins from nearly $700 \mathrm{ft}$ $(215 \mathrm{~m})$ near Silver City, about $2 \mathrm{mi}(3 \mathrm{~km})$ east of the area, to less than $500 \mathrm{ft}(155 \mathrm{~m})$ about $7 \mathrm{mi}(11$ $\mathrm{km}$ ) to the south (W. S. White, written commun., 1974). The base of the Nonesuch is not exposed in the Porcupine Mountains. In the White Pine mine (sec. 4, T. 50 N., R. 41 W.) and elsewhere, the Copper Harbor Conglomerate and the Nonesuch Formation appear to be conformable.

The Nonesuch Formation is composed of thinly laminated siltstone and very fine to fine-grained sandstone. The rocks are moderate to dark gray, light to dark-olive gray, dark-greenish gray, grayish red, and reddish brown. The finest grained rocks are the darkest and the grayest. The Nonesuch has been described from drill core by White and Wright $(1954,1966)$.

The Nonesuch is a lithic sandstone and siltstone composed predominantly of fragments of preKeweenawan rocks, fragments of schists and other fine-grained rocks, mafic, intermediate, and felsic volcanic rocks, quartz, and a small proportion of feldspar; opaque grains are abundant. Matrix, unidentifiable by optical methods, fills the interstitial spaces.

Although the Nonesuch Formation is structurally concordant with the enclosing formations, it represents a different environment of deposition. The Nonesuch sediments are dominantly massive to evenly laminated, whereas sediments of the Freda Formation and sandstone of the Copper Harbor are dominantly crossbedded. The graded beds and lack of evidence of disturbance in most of them suggest deposition in quiet water. White and Wright (1954) and Moore and others $(1969$, p. 384-386) have suggested an estuarine environment of deposition.

\section{FREDA FORMATION}

The Freda Formation is composed of crossbedded, moderately well sorted sandstone and coarse siltstone interbeded with massive to laminated siltstone. It was named by Lane and Seaman (1907, p. 680,692), who described it as red impure sandstone, locally a conglomerate interbedded with red shale. In the North Ironwood and Little Girl Point quadrangles to the west, nearly half of the Freda is inferred to be siltstone or siltstone and very fine to fine-grained sandstone. Much of the Freda is poorly exposed but where exposures occur in these poorly exposed intervals, the rock is siltstone to fine-grained sandstone. The Freda that is better exposed is very predominantly fine to medium-grained sandstone but includes more than 10 percent siltstone. Hamblin's usuage (1965, p. 951) of Freda Formation is followed in this paper.

The Freda is lithic sandstone and is a maximum of $12,000 \mathrm{ft}(3,660 \mathrm{~m})$ thick along the Montreal River, which separates Michigan from Wisconsin. The formation is concealed by glacial deposits in the area mapped but crops out and was penetrated by drill holes farther south in the Iron River syncline, the axis of which is about $3 \mathrm{mi}(5 \mathrm{~km})$ south of the area. The Nonesuch and Freda are concordant. Where the contact zone is exposed, predominantly gray siltstone grades into predominantly reddish-brown siltstone overlain by reddish-brown sandstone.

A layer of sandy conglomerate to conglomeratic sandstone occurs about 500 feet $(150 \mathrm{~m})$ above the base of the Freda in sec. 16, T. 49 N., R. 47 W., in the Ironwood quadrangle. This conglomeratic layer appears to be very extensive. It was described by Noble (1965) from drill holes near White Pine, where it ranges from 12 to $67 \mathrm{ft}(4-20 \mathrm{~m})$ in thickness, and its base is from 621 to $809 \mathrm{ft}$ (190 to $245 \mathrm{~m}$ ) above the base of the Freda.

The Freda was derived from a terrane of metamorphic rocks, lower Keweenawan volcanic rocks, and iron-formation. The abundance of strained quartz, quartzite, microcline, and sodic plagioclase suggests that most of the Freda is derived from metamorphic, plutonic, and intermediate and felsic volcanic rocks. Sedimentary structures described by Hamblin (1961) suggest the source area was to the south. The very uniform character of the sediments and the very abundant small channel scours suggest that the Freda was deposited by braided streams. 


\section{INTRUSIVE ROCKS}

Two small bodies of diorite are exposed in the area. The relations to the enclosing rock are not certain because no contacts with other rocks are exposed. One intrusive, in the north center of sec. 10, T. 50 N., R. $44 \mathrm{~W}$., was described as a gabbro by Irving (1883, p. 213). The other is at the north end of the eastern peninsula on the south side of Mirror Lake. The Mirror Lake diorite is finer grained than the section 10 diorite; plagioclase crystals of the Mirror Lake diorite range from 0.3 to $2 \mathrm{~mm}$ across, whereas those in the section 10 diorite range from 2 to $5 \mathrm{~mm}$. Modes of one thin section of each diorite show about 60 percent andesine and about 25 percent poikilitic pyroxene. The andesine and pyroxene are fractured and altered to chlorite and other optically undetermined minerals. Opaque minerals form about 10 percent of the rocks.

\section{STRUCTURE}

The Porcupine Mountain anticline is a large fold on the southern flank of the basin of the Portage Lake Volcanics beneath Lake Superior. The Iron River and Presque Isle synclines separate the anticline from the northward-dipping middle Keweenawan volcanic rocks of the unnamed formation about $8 \mathrm{mi}(13 \mathrm{~km})$ to the south of the axis of the anticline. The Porcupine Mountain anticline occurs north of a bend in the strike of the northward-dipping rocks of the south. The rocks near an axis that bisects this major bend are uplifted more than those on strike to the east and west. The Iron River and Presque Isle synclines appear to be parts of a syncline that extends nearly parallel with the shore of Lake Superior from Clinton Point, Wis., to an undetermined distance east of the Porcupine Mountains. The structural amplitude between the crest of the Porcupine Mountain anticline and the trough of the Iron River syncline is at least $8,000 \mathrm{ft}$ $(2,440 \mathrm{~m})$ and may be more than $11,000 \mathrm{ft}(3,350 \mathrm{~m})$. The Porcupine fault, a reverse fault along most of the anticline's southern limb, has a displacement of more than 5,000 ft $(1,525 \mathrm{~m})$. The Porcupine Mountain fold is much larger than folds in the Portage Lake Volcanics near Calumet, Mich., which are low swells found only during detailed mapping.

The Porcupine Mountain anticline is itself folded. An arcuate anticline axis extends from about half a mile south of Union Bay, on the north-trending segment of the South Boundary Road, across the northern part of the felsite of the unnamed formation to near Mirror Lake, where it bends southward. North of the axis, the rocks dip lakeward with small regular changes in strike and dip. South of the anticlinal axis is a shallow syncline having an axis parallel to and about $0.5 \mathrm{mi}(0.8 \mathrm{~km})$ south of the anticlinal axis. Two structures bound the south side of the shallow syncline; an anticlinal nose and a reverse fault. The southeastward-plunging nose of the anticline is east of Lost Creek. The anticline does not extend westward; instead it is bounded by a fault or a series of faults on the west and south. The fault(s) is(are) related to the Porcupine fault, a major reverse fault with a displacement of $5,000 \mathrm{ft}$ $(1,525 \mathrm{~m})$ or more, which truncates the south limb of the shallow syncline farther west. The displacement of the fault bounding the anticlinal nose decreases eastward and the fault gradually dies out. A fault of smaller displacement extends along the upper Union River drainage and westward.

Many small faults probably occur, but few were seen. Many of the faults shown on previous maps of the area were not confirmed. Earlier interpretations had followed miscorrelations of the lava flows; consequently, some topographic lows that exist because of differential erosion of sedimentary rocks were ascribed to erosion along faults.

The Porcupine Mountains anticline formed after the Freda Formation was deposited; the Freda is deformed along with the underlying older Keweenawan rocks in the Iron River and Presque Isle synclines.

\section{REFERENCES CITED}

Butler, B. S., and Burbank, W. S., 1929, The copper deposits of Michigan: U.S. Geol. Survey Prof. Paper 144, 238 p.

Chaudhuri, Sambhudas, and Faure, Gunter, 1967, Geochronology of the Keweenawan rocks, White Pine, Michigan: Econ. Geology, v. 62, no. 8, p. 1011-1033.

Doonan, C. J., and Henrickson, G. E., 1969, Ground water in Ontonagon County, Michigan: Michigan Geol. Survey Water Inv. 9, $27 \mathrm{p}$.

Hamblin, W. K., 1961, Micro-cross-lamination in upper Keweenawan sediments of northern Michigan: Jour. Sed. Petrology, v. 31, no. 3, p. 390-401.

1965, Basement control of Keweenawan and Cambrian sedimentation in Lake Superior region: Am. Assoc. Petroleum Geologists Bull., v. 49, no. 7, p. 950-958.

Hubbard H. A., 1972, Source of pebbles of volcanic rocks in the middle and upper Keweenawan conglomerates of . northern Michigan: Jour. Geology, v. 80, p. 627-629.

Irving, R. D., 1883, The copper-bearing rocks of Lake Superior : U.S. Geol. Survey Mon. 5, 464 p.

Johnson, R. F., and White, W. S., 1969, Preliminary report on the bedrock geology and copper deposits of the Matchwood quadrangle, Ontonagon County, Michigan: U.S. Geol. Survey open-file rept., $31 \mathrm{p}$.

Lane, A. C., and Seaman, A. E., 1907, Notes on the geological section of Michigan; Part I, The pre-Ordovician: Jour. Geology, v. 15, p. 680-695.

Meshref, W. M., and Hinze, W. J., 1970, Geologic interpreta- 
tion of aeromagnetic data in western upper peninsula of Michigan: Michigan Geol. Survey Rept. Inv. 12, 22 p.

Moore, L. R., Moore, J. R. M., and Spinner, E., 1969, A geomicrobiological study of the Pre-Cambrian Nonesuch Shale : Yorkshire Geol. Soc. Proc., v. 37, pt. 3, no. 17, p. 351-394.

Noble, J. H., 1965, The petrology of the conglomerate zone of the Freda Formation of northern Michigan: Ohio, Miami Univ., unpub. M.S. thesis, 120 p.

Thaden, R. E., 1950, The Porcupine Mountains Red Rock: Michigan State Univ., unpub. M.S. thesis, $99 \mathrm{p}$.

Van Hise, C. R., and Leith, C. K., 1911, The Geology of the Lake Superior region: U.S. Geol. Survey Mon. 52, 626 p.

White, W. S., 1972, The base of the upper Keweenawan, Michigan and Wisconsin: U.S. Geol. Survey Bull. 1354-F, p. F1-F23.

White, W. S., Brooks, E. R., Hubbard, H. A., Johnson, R. F. and Wilband, J. T., 1971, Keweenawan stratigraphy of westernmost Michigan [abs.], in Inst. on Lake Superior
Geology, 17th Ann., 1971, Abs. and Field Guides: Duluth, Minn., p. 71-72.

White, W. S., and Wright, J. C., 1954, The White Pine Copper deposit, Ontonagon County, Michigan: Econ. Geology, v. 49 , no. 7 , p. $675-716$.

1960, Lithofacies of the Copper Harbor Conglomerate, northern Michigan: U.S. Geol. Survey Prof. Paper 400-B, p. B5-B8.

, 1966, Sulfide-mineral zoning in the basal Nonesuch Shale, northern Michigan. Econ. Geology, v. 61, no. 7, p. 1171-1189.

Wright, Fred Eugene, 1905, Report of progress in the Porcupines: Michigan Geol. Survey Rept. 1903, p. 33-44.

Wright, Fred Eugene, and Lane, A. C., 1909, Preliminary geological map of the Porcupine Mountains and vicinity: Michigan Geol. Survey Rept. 1908, pl. 1. 


\title{
LOWER KEWEENAWAN VOLCANIC ROCKS OF MICHIGAN AND WISCONSIN
}

\author{
By HAROLD A. HUBBARD, Reston, Va. \\ Work done in cooperation with the Geological Survey Division, \\ Michigan Department of Natural Resources
}

\begin{abstract}
Unconformable sequences of Keweenawan volcanic rocks occur in Michigan and adjacent Wisconsin. The sequences differ in types of rocks, magnetic properties, metamorphic grade, and pattern of structural deformation; they had different vent areas and were deposited in basins that were only partly overlapping. The older sequence includes the Bessemer Quartzite and two newly named formations that are here assigned to the lower Keweenawan. The younger se-quence-includes-the well-known Portage Lake Volcanics and a younger unnamed formation, both of middle Keweenawan age. Formerly the older rocks were interpreted as a faultrepeated part of the Portage Lake Volcanics, but new evidence indicates that these older rocks had been metamorphosed and tilted and were being eroded in middle Keeweenawan time.
\end{abstract}

The lower Keweenawan is here redefined to include a thick sequence of intermediate and mafic volcanic rocks formerly correlated with the Portage Lake Volcanics of middle Keweenawan age. The lower Keweenawan rocks form a northward-dipping belt that extends more than $100 \mathrm{mi}(160 \mathrm{~km})$ from Sturgeon Falls in southern Houghton County, Mich., westward to Grandview, Wis. The field work on which this study is based was done in cooperation with the Geological Survey Division of the Michigan Department of Natural Resources from 1965 to 1971.

\section{TERMINOLOGY}

Keweenawan rocks have been divided in several ways, which are summarized in figure 1 . The lower Keweenawan rocks, as redefined here, include three formations: the Bessemer Quartzite, ${ }^{1}$ the Siemens Creek Formation, ${ }^{2}$ and the Kallander Creek Formation. ${ }^{2}$ The Siemens Creek and the Kallander Creek Formations make up the Powder Mill Group, ${ }^{2}$ all three of which are defined in this paper. Subdivision of Keweenawan rocks in western Michigan is shown in table 1.

${ }^{1}$ Bessemer Quartzite or Sandstone of Seaman (in Snelgrove and thers, 1944) is hereln adopted as Bessemer Quartzite for U.S. Geological Survey usage.

${ }_{2}$ New names formally proposed and adopted herein for U.S. Geological Survey usage.

\section{DISTRIBUTION}

The distribution of the lower, middle, and upper Keweenawan rocks in Michigan and adjacent Wiscon$\sin$ is shown in figure 2. Lower Keweenawan rocks extend at least $100 \mathrm{mi}(160 \mathrm{~km})$ along strike, and their western limit in Wisconsin was not determined. Their distribution east of Lake Gogebic, Mich., was based mostly on interpretation of geophysical maps.

Siemens Creek rocks crop out between Sturgeon Falls and Silver Mountain, Mich., and Mellen, Wis. Kallander Creek rocks crop out from the Black River in western Michigan to Davis Hill, south of Grandview, Wis., and may extend farther west. Structural complications occur near Mellen, Wis.; consequently, correlation of the Kallander Creek rocks west of Mellen with similar rocks to the east is tenuous.

\section{LOWER KEWEENAWAN Bessemer Quartzite}

The Bessemer Quartzite, named by Seaman (in Snelgrove and others, 1944) for exposures near Bessemer, Mich., includes thin layers of laminated sandstones and crossbedded sandstone; the formation is about $300 \mathrm{ft}(90 \mathrm{~m})$ thick. These rocks were called lower Keweenawan or lower Keweenawan sandstone by Van Hise and Leith $(1911$, p. 376). The Bessemer is exposed in sparse, small outcrops scattered from Mellen, Wis. (Aldrich, 1929, p. 230, 246) to east of Lake Gogebic, Mich. (Fritts, 1969). The Bessemer Quartzite is unconformable with the underlying Tyler Formation of Precambrian age. The two formations seem almost concordant at nearly all exposures, but regionally the Tyler is truncated. The Tyler is about $10,000 \mathrm{ft}(3,050 \mathrm{~m})$ thick at the state line and thins eastward and westward; it is completely eroded east of Wakefield, Mich., and about 10 miles $(16 \mathrm{~km})$ west of Mellen, Wis.

The Bessemer is a well-cemented quartzite composed of subangular to subrounded quartz grains in a very 


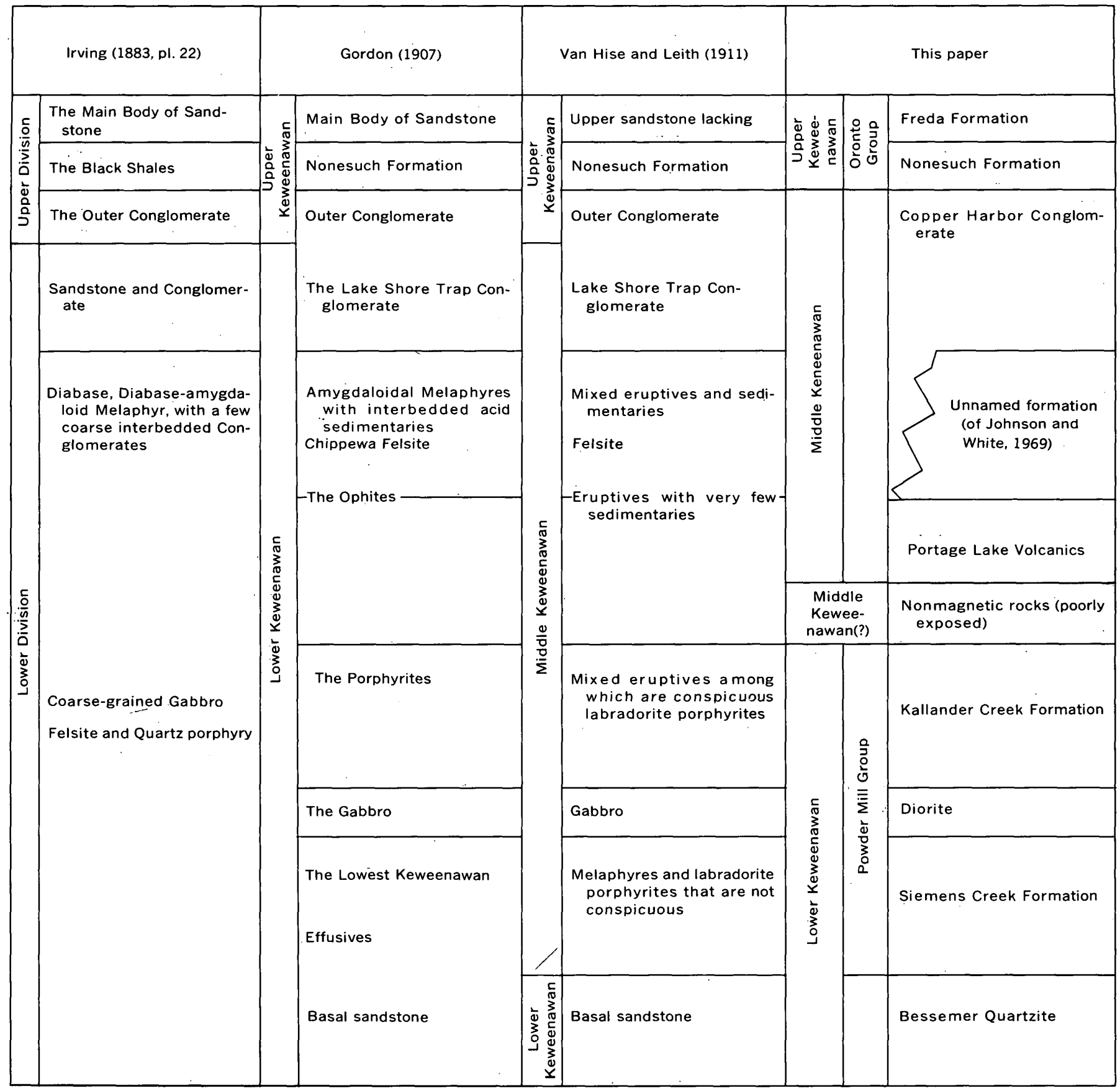

Figure 1.-Comparison of subdivisions of Keweenawan Series used for western Michigan. The Black Shales (Irving, 1883, pl. 22) are called Nonesuch shale in Irving's text, Nonesuch Belt on his plate 17, and Nonesuch Slate Belt on his plate 18.

fine grained, optically unidentifiable matrix. The matrix is not conspicuous in hand specimen, but is seen in thin section to form $35-60$ percent of the rock. Eleven thin sections showed that the sand grains are 95-100 percent quartz, 0-1 percent feldspar, and 0-4 percent lithic fragments. In crossbedded layers, more than 80 percent of the grains are fine- to medium-sand size; in thinly laminated sandstone, more than 80 percent of the grains are very fine to fine-sand size.

\section{Powder Mill Group}

The Powder Mill Group of early Keweenawan age includes two formations totaling about $20,000 \mathrm{ft}(6,100$ $m$ ) in thickness: The Siemens Creek Formation and the Kallander Creek Formation. The names are derived from streams that cross the outcrop belt of the group (fig. 3). The type locality is along the Powder Mill Creek valley and the hills to the east secs. 5 and 8, T. 47 N., R. 46 W., and sec. 33, T. 48 N., R. 44 W., 
TABLE 1.-Stratigraphic nomenclature for western Michigan

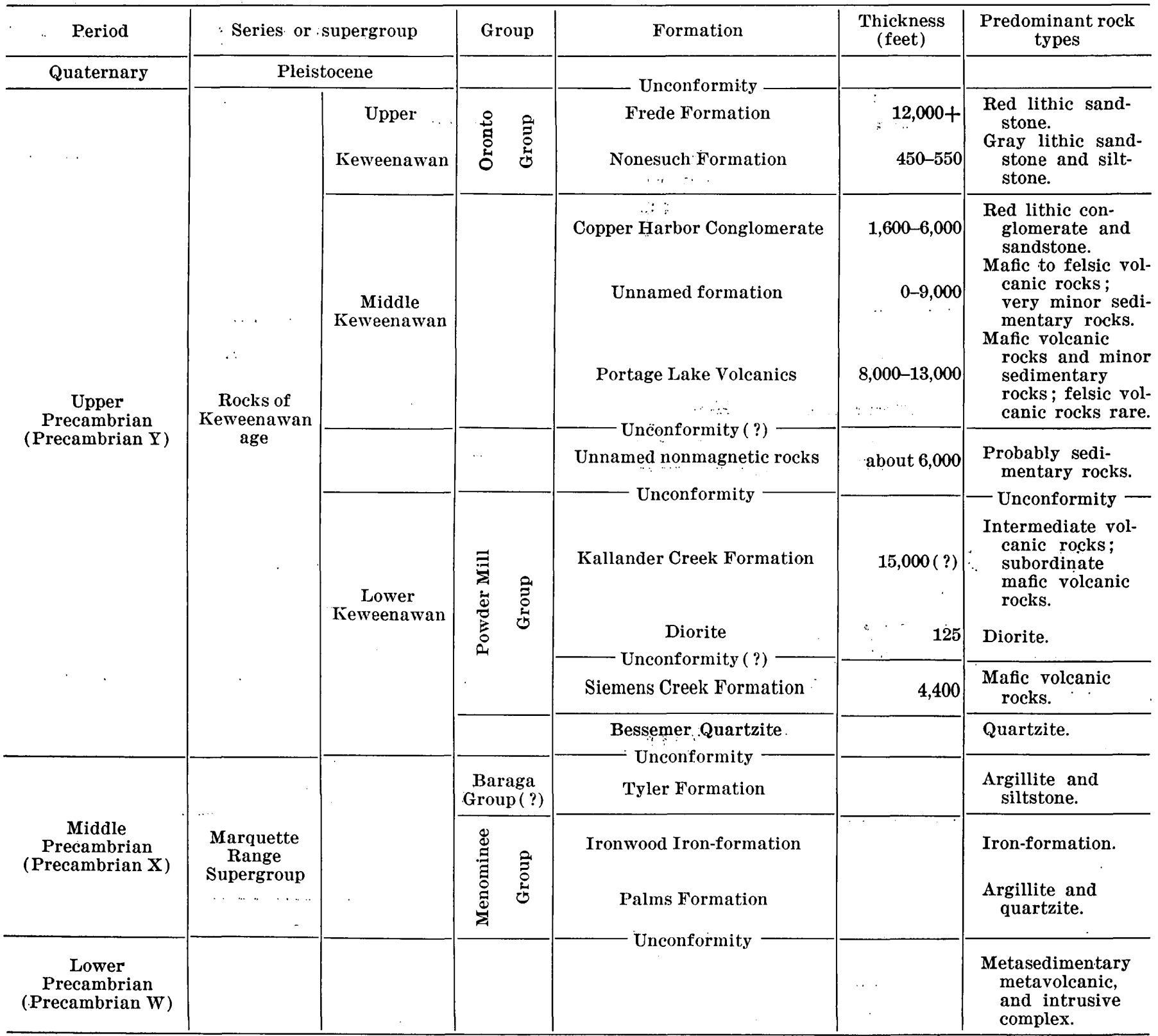

Gogebic County, Mich. Formerly the group was called the South Range Traps (Irving, 1883, p. 201) and was not distinguished from the overlying middle Keweenawan rocks (White, 1966, p. E2). The group is intruded by the Mellen Intrusive Complex ${ }^{3}$ in Wisconsin and by diorite in sec. 17, T. 47 N., R. 47 W., on the Montreal River in Michigan. Paleomagnetic studies by Books, White, and Beck (1966,p. D117-D123) suggest that the Powder Mill rocks were already steeply dipping at the time of intrusion of the Mellen Complex. Rocks of the complex do not occur in exposures of middle Keweenawan rocks in western Michigan and

\footnotetext{
${ }^{3}$ Formerly named Mellen Gabbro by Dutton and Bradley (1970).
}

were not seen in exposures of middle Keweenawan volcanic rocks in Wisconsin.

\section{Siemens Creek Formation}

The Siemens Creek Formation is composed predominantly of thin flows of fine-grained basalt. It is about $4,400 \mathrm{ft}^{\circ}(1,340 \mathrm{~m})$ thick near Ironwood, Mich., thins westward in Wisconsin, and is absent west of Mellen. East of long $90^{\circ}$, the thickness is unknown because sediments conceal the upper part. The Siemens Creek is comfortable with the underlying Bessemer Quartzite, and very rare interbeds of Bessemer sandstone occur in the lower $100 \mathrm{ft}(30 \mathrm{~m})$ of the Siemens Creek Formation. The formation underlies a prominent 


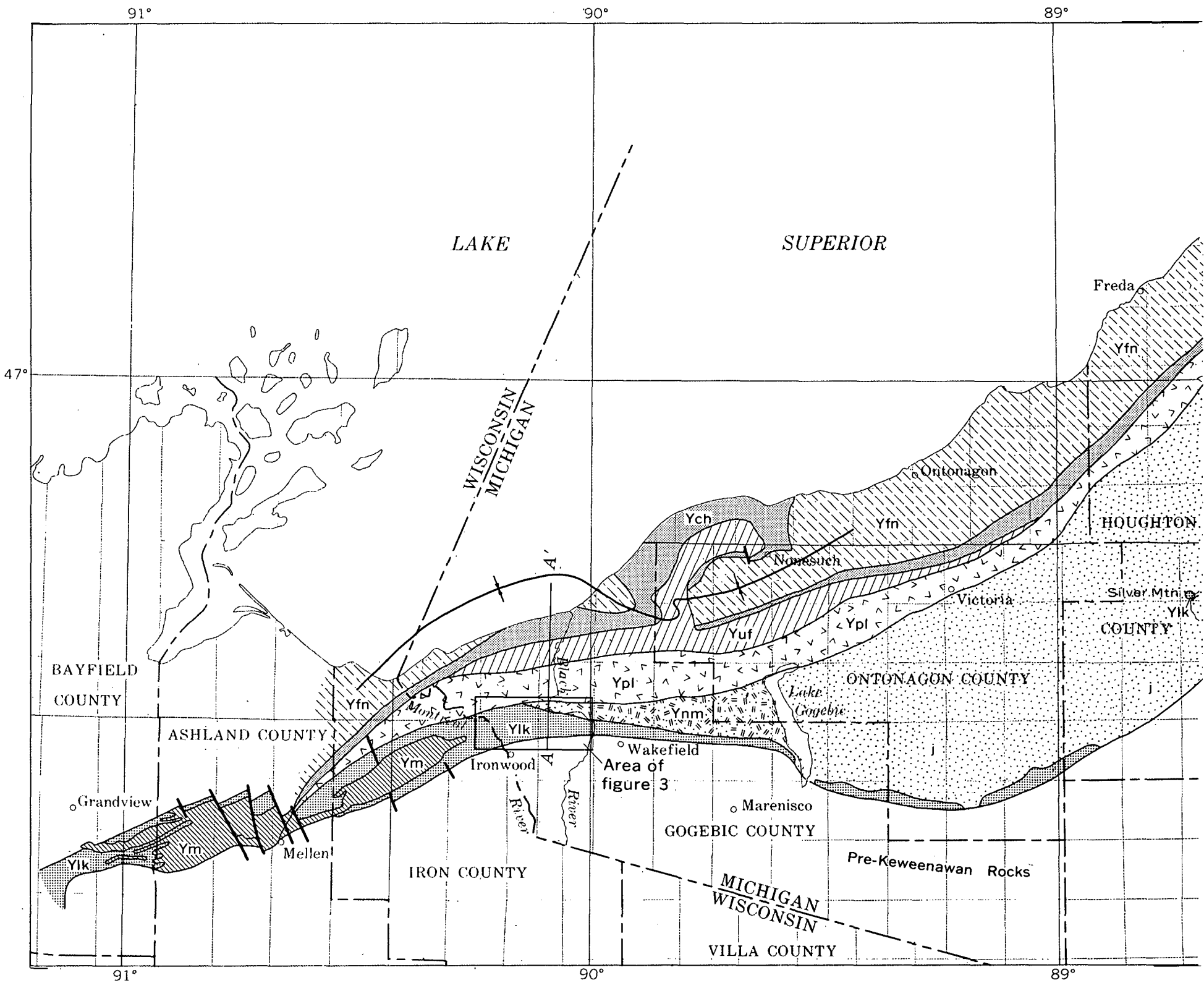

FIGURE 2.-Geologic map of westernmost Michigan and adjacent Wisconsin and section (Michigan, near the Black River) showing

east-west belt of knobby hills north of U.S. Route 2 in Michigan.

The Siemens Creek flows are thin; the average thickness is about $9 \mathrm{ft}(3 \mathrm{~m})$. They are less than $45 \mathrm{ft}(14$ $\mathrm{m})$ thick, except the basal flows which are $175 \mathrm{ft}(53$ $\mathrm{m})$ and $115 \mathrm{ft}(35 \mathrm{~m})$ thick in sec. $12, \mathrm{~T} .47 \mathrm{~N} ., \mathrm{R} .47$ W. The lower $40 \mathrm{ft}(12 \mathrm{~m})$ of the lowermost flow is pillowed. All flow tops are pahoehoe type having very low relief and containing less than 5 percent vesicles; sparse pipe vesicles occur at the base of some flows. Except for the bottom flow, all flows were subaerially extruded and were not subsequently eroded or weathered significantly.

The rocks are predominantly basalt but include ande- site (table 2). They are olive gray to dark greenish gray and mottled with irregular patches of chlorite. The lava flows are holocrystalline and have subophitic to intersertal textures; the more felsic flows are porphyritic with plagioclase phenocrysts $0.4-1 \mathrm{~mm}$ long. The minerals present include plagioclase, clinopyroxene, magnetite, and apatite; the plagioclase is saussuritized, and now most of it is albite to oligoclase, chlorite, and epidote, but some of it is represented only by chlorite and epidote. The pyroxene is less altered; it contains chlorite and actinolite. The ilmenite is commonly altered to leucoxene. The vesiclefilling minerals include quartz, epidote, chlorite, and calcite. 


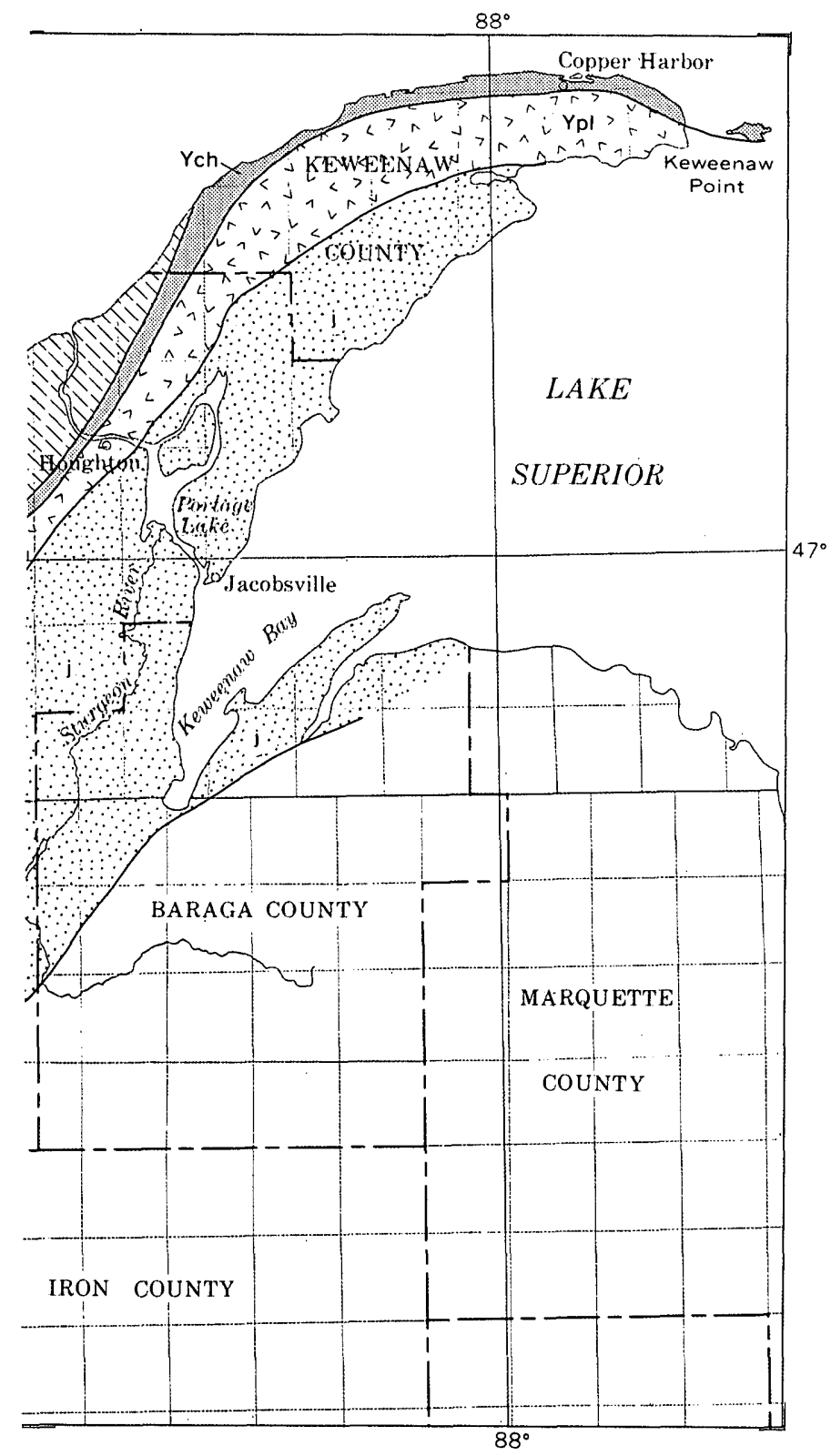

\section{EXPLANATION}
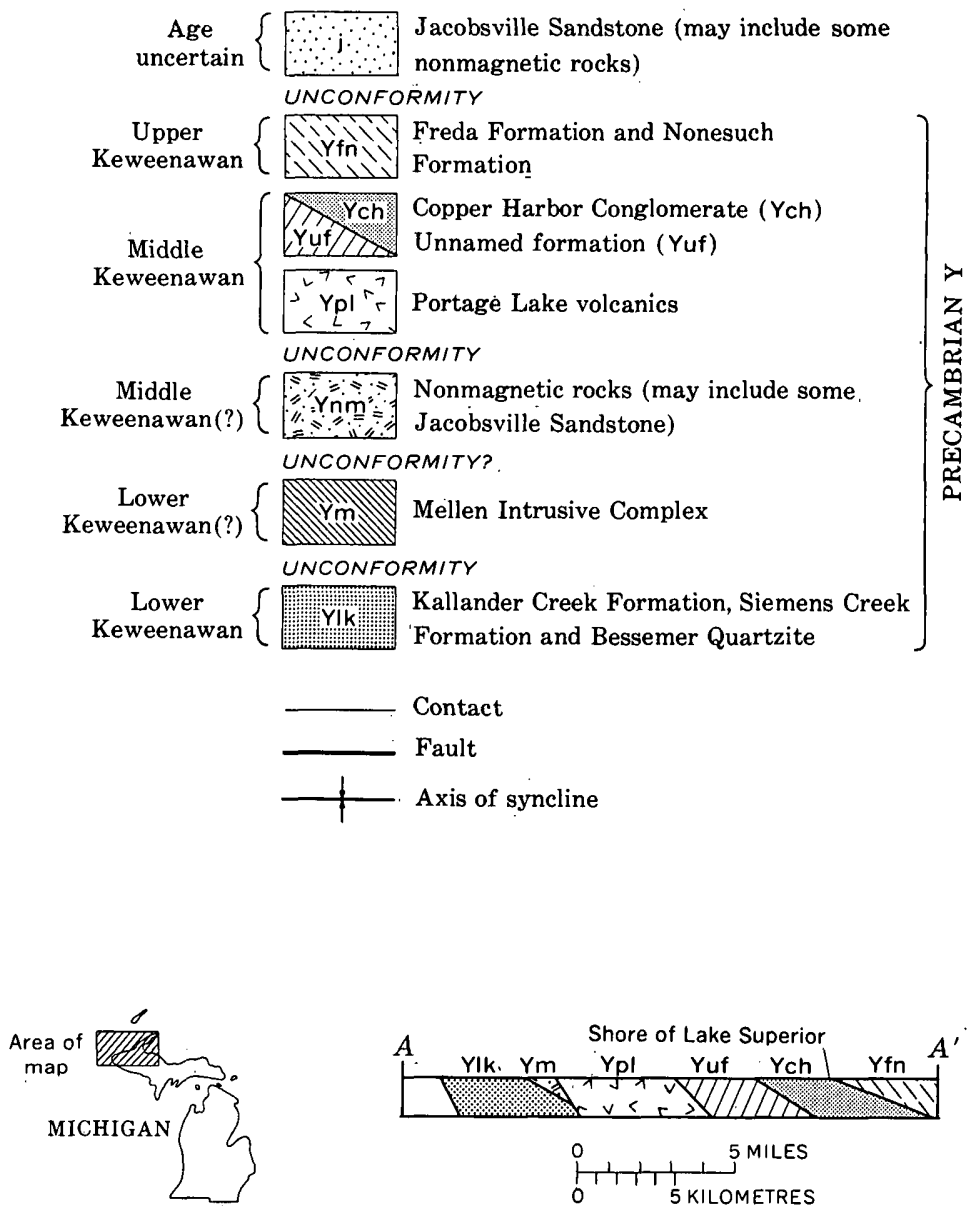

distribution of Keweenawan rocks. Geology in Michigan modified from White (1971); geology in Wisconsin modified from Aldrich (1929).

\section{Kallander Creek Formation}

The Kallander Creek Formation is composed predominantly of lava flows of intermediate composition (table 2). About 4,000 ft $(1,220 \mathrm{~m})$ of it is exposed in Michigan, but the total thickness may be about 15,000 $\mathrm{ft}(4,500 \mathrm{~m})$. Its relation to the underlying Siemens Creek Formation is not certain; Gordon (1907, p. 457458) arbitrarily placed the contact at a diorite sill. The rocks below the sill are green because of uralitization, and those above the sill are finer grained and lighter green. Exposures are very poor and sparse near this contact, which may be an unconformity because rocks above the contact dip as much as $15^{\circ}$ more than those beneath it. The rocks form a discontinuous band of hills in Michigan west of the Black River and are exposed in stream valleys in Wisconsin. No Kallander Creek rocks were seen east of the Black River.

The rocks are basalt, andesite, and quartz-bearing felsite if classified by optical methods, but are rhyodacite, trachyandesite, andesite, and basalt if classified by chemical norms (table 2, fig. 4). The rocks are chiefly aphanitic or very fine grained, and some are glomeroporphyritic. They are predominantly moderate to dark gray or bluish gray, but some are purple, dark brown, and reddish brown. The flows range from about 


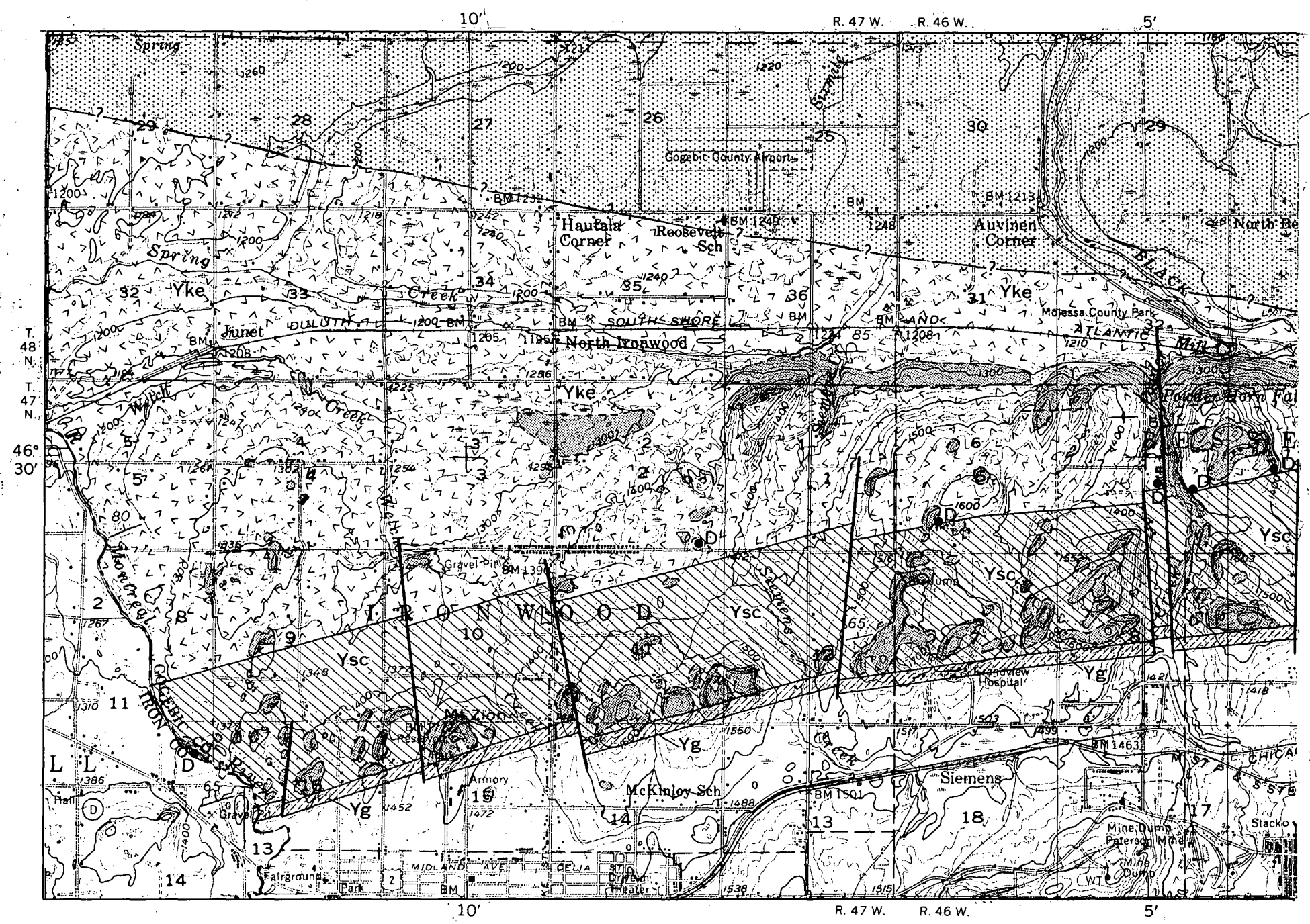

Frgure 3.-Geologic map of part of the North Ironwood and Ironwood quadrangles, Michigan, showing the type locality of the Siemens Ironwood (1956) quadrangles, U.S. Geological

30 to more than $200 \mathrm{ft}(9-60 \mathrm{~m})$ in thickness and average about $80 \mathrm{ft}(25 \mathrm{~m})$. Most flows have autobrecciated tops; some, however, especially porphyritic flows, have smoothly undulating tops and wellrounded, somewhat elongated vesicles that contain chalcedony, quartz, chlorite, calcite, and epidote.

Basalts form the lower $800 \mathrm{ft}(250 \mathrm{~m})$ of the Kallander. Creek Formation and are fine grained, equigranular, dark gray to dark bluish gray, and lack the conspicuous patches of chlorite of the basalts of the Siemens Creek. They contain oligoclase, clinopyroxene, opaque minerals, and chlorite. The intermediate rocks have felted to subtrachytic texture and contain oligoclase, generally in an opaque groundmass; clinopyroxene is seen in a few thin sections. The quartz latite flows are recrystallized and have a snowflake texture.

Sediments are very uncommon, and conglomerate composed of volcanic detritus was observed only on
Powderhorn ski hill. In contrast, in the middle Keweenawan rocks, sediments occur at every extensive exposure.

\section{Diorite}

A sill of pyroxene-bearing diorite intruding lower Keweenawan flows is exposed in five places (fig.: 3 ). The maximum observed thickness is about $125 \mathrm{ft}$ ( 38 $\mathrm{m})$. The diorite is a medium- to coarse-grained rock having a hypidiomorphic granular texture. Its age is uncertain, but it probably predates middle Keweenawan and may be related to Mellen Intrusive Complex. In Wisconsin, Powder Mill rocks are intruded by gabbro, anorthosite, and related rocks of the complex. During reconnaissance in Wisconsin, no rocks younger than early Keweenawan age were found that were intruded by the complex. 

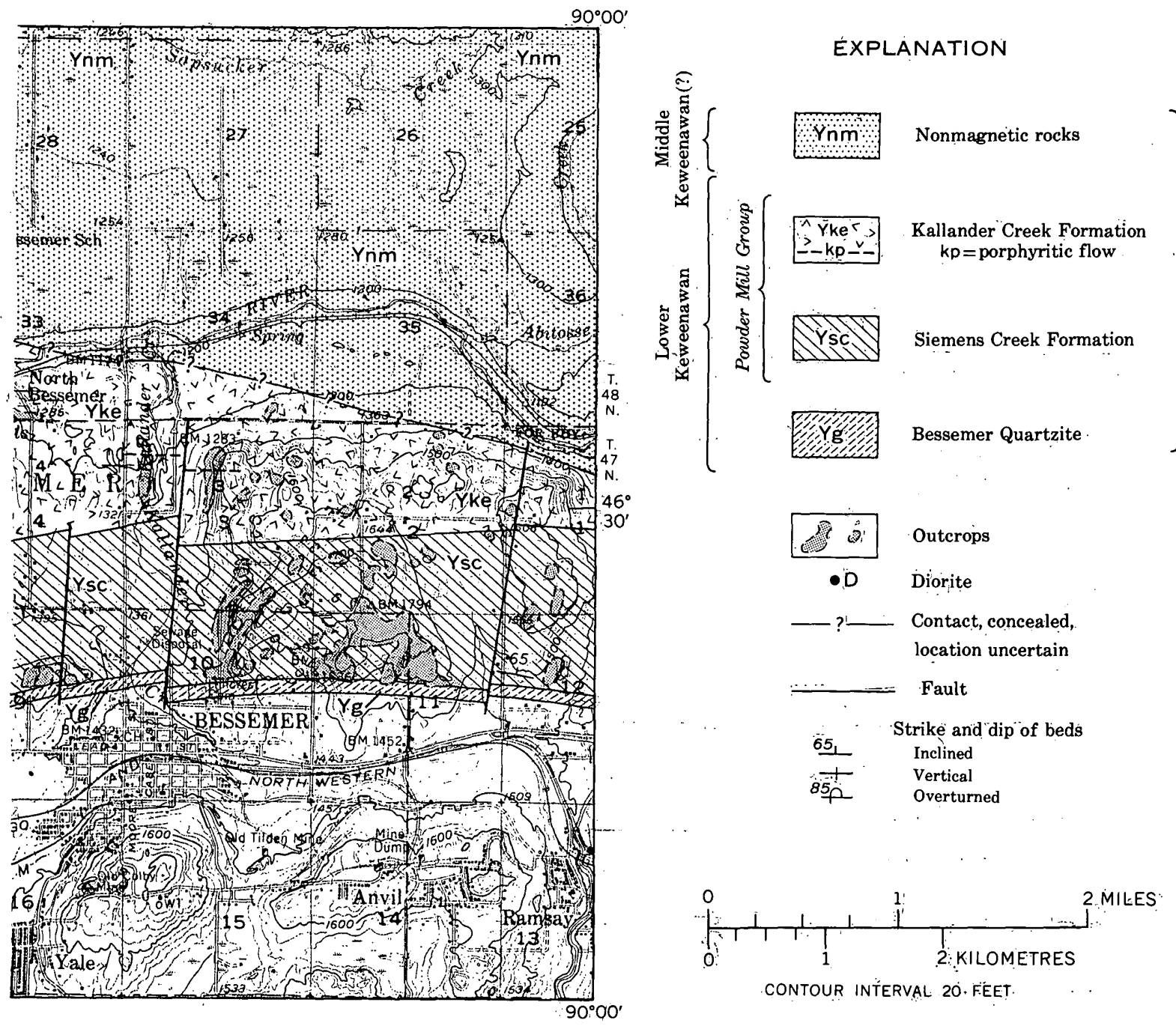

=Creek and Kallander Creek Formations of the Powder Mill Group. Base from Ironwood (1955) and North Survey; geology by H. A. Hubbard, 1965-71.

Diorite exposed in sec. 16, T. 47 N., R. 47 W., contains, at the ends of the feldspars, myrmekite that resembles the myrmekite of a diorite collected from the Mellen Intrusive Complex near Mellen, Wis.

\section{Dikes}

Several mafic dike swarms in rocks of Precambrian $\mathrm{W}$ and $\mathrm{X}$ age near Ironwood, Mich., have been known for a long time. Previously, geologists assumed that the dikes fed middle Keweenawan flows, but recent mapping (Schmidt, 1972) shows that most of these dikes are "Archean" or Precambrian W. A few intruded Precambrian $\mathrm{X}$ rocks and four intruded lower Keweenawan rocks. No dikes were found in middle Keweenawan rocks, indicating that the middle $\mathrm{Ke}$ weenawan feeders were elsewhere, probably to the north. The presence of lower Keweenawan dikes suggests that some lower Keweenawan eruptive centers were to the south. The large dike swarm near Keweenaw Bay (Balsley and others, 1949) is a probable source of some lower Keweenawan flows.

\section{MIDDLE KEWEENAWAN}

The middle Keweenawan rocks consist of four formations (in ascending order): The nonmagnetic rocks, the Portage Lake Volcanics, an unnamed formation and the Copper Harbor Conglomerate (White, 1972). The Portage Lake Volcanics and unnamed formation are described briefly from occurrences in the Ironwood area for the sake of comparison with the lower Keweenawan rocks (table 3).

\section{Nonmagnetic Rocks}

The magnetic volcanic rocks of early and middle Keweenawan age are separated by a northward-thick- 
TABLE 2.-Chemical analyses and CIPW norms of 13 lower Keweenawan volcanic rocks of the Ironwood area, Michigan [Rapid rock analysis by L. Artis, S. Botts, G. Chloe, P. Elmore, J. Glenn, J. Kelsey, L. Shapiro, and H. Smith]

\begin{tabular}{|c|c|c|c|c|c|c|c|c|c|c|c|c|c|}
\hline \multirow{4}{*}{$\begin{array}{l}\text { Rock type } \\
\text { Lab. No } \\
\text { Reference No., } \\
\text { fig. } 4\end{array}$} & \multirow{3}{*}{$\begin{array}{c}\text { Siemens } \\
\text { Basalt } \\
\text { W-169- } \\
\mathbf{9 8 8}\end{array}$} & \multirow{3}{*}{$\begin{array}{l}\text { Creek Fol } \\
\begin{array}{c}\text { Andesite } \\
\text { W-169- } \\
991\end{array}\end{array}$} & \multirow{4}{*}{$\begin{array}{c}\text { mation } \\
\text { Trachy- } \\
\text { andesite- } \\
\begin{array}{c}\mathrm{W}-169- \\
994 \\
3\end{array}\end{array}$} & \multicolumn{10}{|c|}{ Kallander Creek Formation } \\
\hline & & & & \multicolumn{3}{|c|}{ Rhyodacite } & \multirow{3}{*}{$\begin{array}{c}\text { Basalt } \\
\text { W-172- } \\
991 \\
7 \\
\end{array}$} & \multicolumn{2}{|c|}{ Trachyandesite } & \multirow{3}{*}{$\begin{array}{c}\text { Trachy- } \\
\text { basalt } \\
\text { W-169- } \\
989 \\
10\end{array}$} & \multirow{3}{*}{$\begin{array}{c}\text { Andesite } \\
\text { W-169- } \\
993 \\
11\end{array}$} & \multicolumn{2}{|c|}{ Trachyandesite } \\
\hline & & & & $\begin{array}{c}\text { W-172- } \\
994\end{array}$ & $\begin{array}{c}\mathrm{W}-172- \\
995\end{array}$ & $\begin{array}{c}\mathrm{W}-172- \\
987\end{array}$ & & $\begin{array}{c}\mathrm{W}-169 \\
996\end{array}$ & $\begin{array}{c}\overline{\mathrm{W}}-\overline{169} \\
998\end{array}$ & & & $\begin{array}{c}W-172- \\
988\end{array}$ & $\begin{array}{c}\overline{\mathrm{w}}-\overline{172} \\
996\end{array}$ \\
\hline & 1 & 2 & & 4 & 5 & 6 & & 8 & 9 & & & 12 & 13 \\
\hline \multicolumn{14}{|c|}{ Chemical analyses } \\
\hline $\mathrm{SiO}_{2}$ & 50.2 & 50.8 & 50.0 & 68.3 & 65.5 & 62.5 & 52.4 & 52.2 & 52.2 & 51.2 & 51.6 & 48.9 & 48.7 \\
\hline $\mathrm{Al}_{2} \mathrm{O}_{3}$ & 15.1 & 13.5 & 15.8 & 12.8 & 12.3 & 13.3 & 16.2 & 16.0 & 13.8 & 14.2 & 14.1 & 14.8 & 14.8 \\
\hline $\mathrm{Fe}_{2} \mathrm{O}_{3}$ & 3.0 & 4.0 & 3.3 & 6.1 & 6.9 & 5.9 & 4.1 & 5.7 & 9.4 & 6.1 & 4.7 & 8.1 & 6.6 \\
\hline $\mathrm{FeO}$ & 7.0 & 9.3 & 7.3 & .5 & 1.4 & 3.2 & 5.9 & 5.5 & 5.0 & 6.7 & 8.3 & 4.5 & 5.1 \\
\hline MgO _- - - - & 6.8 & 4.6 & 6.4 & .4 & 1.4 & 1.5 & 6.0 & 3.4 & 2.7 & 4.4 & 3.8 & 4.6 & 5.6 \\
\hline $\mathrm{CaO} \ldots \ldots$ & 10.2 & 8.0 & 8.0 & .8 & 1.4 & .9 & 7.4 & 5.2 & 5.3 & 6.2 & 7.5 & 5.4 & 5.7 \\
\hline $\mathrm{Na}_{2} \mathrm{O}$ & 2.1 & 2.7 & 3.0 & 3.7 & 2.1 & 2.2 & 2.8 & 4.0 & 3.4 & $2: 4$ & 3.0 & 3.6 & 3.3 \\
\hline $\mathrm{K}_{2} \mathrm{O}$ & .3 & .9 & 1.9 & 4.4 & 5.6 & 6.5 & 1.0 & 1.7 & 2.1 & 1.0 & .9 & 1.4 & 1.7 \\
\hline $\mathrm{H}_{2} \mathrm{O}-\ldots$ & .4 & .8 & .2 & .2 & .4 & .4 & .6 & 1.2 & 1.2 & 1.1 & .7 & .7 & .8 \\
\hline $\mathrm{H}_{2} \mathrm{O}+\ldots$ & 3.4 & 1.7 & 2.1 & .70 & 1.3 & 1.5 & 1.7 & 2.0 & 2.5 & 2.5 & 1.4 & 2.8 & 3.0 \\
\hline $\mathrm{TiO}_{2}$ & 1.2 & 2.9 & 1.5 & .8 & 1.2 & 1.0 & 1.0 & 2.3 & 0.6 & 2.8 & 2.8 & 2.7 & 2.6 \\
\hline $\mathrm{P}_{2} \mathrm{O}_{5}$ & .2 & .5 & .3 & .4 & .9 & 1.0 & .3 & .6 & 1.0 & .6 & .7 & 1.1 & 1.2 \\
\hline $\mathrm{MnO}$ & .2 & .2 & .2 & .1 & .1 & .2 & .1 & .1 & .2 & .2 & .2 & .1 & .1 \\
\hline $\mathrm{CO}_{2}$ & .05 & .05 & .05 & $<.1$ & $<.1$ & $<.1$ & $\leq .1$ & .1 & $<.1$ & $<.1$ & .2 & .4 & .3 \\
\hline Sum & 100 & 100 & 100 & 99 & 99 & 100 & 99 & 100 & 99 & 99 & 100 & 99 & 99 \\
\hline \multicolumn{14}{|c|}{ CIPW norms } \\
\hline Quartz _- & 4.6 & 7.1 & $-\cdots$ & 26.5 & 25.6 & 18.7 & 4.2 & 7.3 & 6.6 & 10.6 & 8.2 & 2.4 & 1.1 \\
\hline Corundum -- & --- & --- & -- & 1.5 & 2.6 & 2.6 & --- & --- & --- & $--\overline{-}$ & --- & --- & \\
\hline Orthoclase -- & 1.7 & 5.6 & 11.1 & 26.7 & 33.9 & 38.9 & 6.1 & 10.0 & 12.8 & 6.7 & 5.6 & 8.9 & 10.6 \\
\hline Albite & 18.3 & 23.6 & 26.2 & 32.0 & 18.3 & 19.4 & 24.6 & 34.6 & 30.4 & 21.0 & 26.2 & 32.0 & 29.3 \\
\hline Anorthite --- & 32.2 & 22.5 & 24.7 & 1.1 & $\ldots$ & --- & 29.4 & 21.1 & 16.9 & 26.1 & 22.8 & 21.1 & 21.7 \\
\hline Diopside _..- & 15.8 & 11.9 & 12.9 & --- & -- & --- & 6.3 & 1.4 & 3.0 & 2.0 & 9.2 & --- & .6 \\
\hline Hypersthene & 21.4 & 17.8 & 9.7 & 7.7 & 12.3 & 13.7 & 23.7 & 16.9 & 20.1 & 22.6 & 16.7 & 23.2 & 25. \\
\hline Forsterite -- & --- & --- & 5.0 & --- & --- & -- & --- & -- & -- & --- & -- & -- & -- \\
\hline Fayalite _...- & $\ldots$ & --- & 3.5 & --- & -- & --- & $-\infty$ & --- & --- & --- & --- & --- & --- \\
\hline Magnetite - & 3.2 & 4.4 & 3.5 & 1.9 & 2.6 & 2.8 & 3.2 & 3.0 & 6.3 & 4.2 & 4.2 & 4.2 & 3.7 \\
\hline Ilmenite _. & 2.3 & 5.8 & 2.9 & 1.5 & 1.4 & 1.8 & 1.8 & 4.4 & 1.2 & 5.5 & 5.4 & 5.5 & 5.2 \\
\hline Apatite _...- & .3 & 1.3 & .7 & 1.0 & 2.0 & 1.7 & .7 & 1.3 & 2.7 & 1.3 & 1.7 & 2.7 & 2.7 \\
\hline
\end{tabular}

1. Road west of Powder Mill Creek at north entrance to Powderville Ski village ; $S W 1 / 4 \mathrm{NE} 1 / 4$ sec. $8, T .47 \mathrm{~N}$., $R$. $46 \mathrm{~W}$.
2. Bessemer quarry about $1,000 \mathrm{ft}(305 \mathrm{~m})$ above base of formation ; . Bessemer quarry about $1,000 \mathrm{ft}(305 \mathrm{~m}) \mathrm{N}$.

3. Bessemer quarry, basal exposed flow; $\mathrm{SW} 1 / 4 \mathrm{NE} 1 / 4$ sec. 10 , $\mathrm{T}$. 46 W., R. 47 N.

4. Welch Creek; center of north line of sec. 4, T. 47 N., R. $47 \mathrm{~W}$.

5. Siemens Creek, NW $1 / 4$ NE $1 / 4$ sec. 1 , T. 47 N., R. 47 W.

6. Powder Mill Creek ; SW $1 / 4 \mathrm{NE}^{1 / 4}$
7. Pec. 5, T. 47 N., R. 46 W.

ening wedge of nonmagnetic rocks which was identified by E. R. King (this issue) by an analysis of a north-south aeromagnetic profile west of the Black River. The wedge thickens northward from a feather edge over the lower Keweenawan rocks to about 7,000 $\mathrm{ft}(2,135 \mathrm{~m})$ beneath the southern edge of the middle Keweenawan rocks; the lower surface of the nonmagnetic rocks slopes northward at about $18^{\circ}$. No nonmagnetic rocks crop out near the profile. Sedimentary rocks have similar nonmagnetic expression, and sedimentary rocks crop out on strike about 5 miles $(8 \mathrm{~km})$ to the east.

Sedimentary rocks are exposed at several places along Jackson Creek in the southern part of the Thomaston 15-minute quadrangle and more than 2,000 $\mathrm{ft}(610 \mathrm{~m})$ of sediments similar to those exposed were penetrated in a drill hole north of Marinesco (Trent, 1973). The rocks are poorly indurated sandstone and conglomerate composed principally of quartz, but they
8. Powder Mill Creek just upstream from Powderhorn Falls; 9. Powder Mill Creek below Powder Mill Falls; $N W 1 / 4 \mathrm{NE} 1 / 4$ sec. 5 ,
T. 47 N., R. 46 W.

10. Siemens Creek, NW N/4NE1/4 sec. 1, T. 47 N., R. 47 W.

12. Powder Mill Creek, flow below flow at reference no. 6 ; SW $1 / 4 \mathrm{NE} 1 / 4$, 13. Powder Mill Creek, second flow above diorite sill; NW $1 / 4 \mathrm{SE} 1 / 4$

contain clasts of iron-formation and dolomite. All rock types in the sediments exposed about $500 \mathrm{ft}$ (155 m) north of Gabbro Falls on the Black River could have been derived from the Animikie Group (W. C. Prinz, written commun., 1973).

The relationship between the sandstone of Jackson Creek and other rocks is equivocal because the relationships must be inferred from distant outcrops of incompletely described rocks. Field observations show the sediments are unconformable with the Siemens Creek Formation; the flows dip nearly vertically at Gabbro Falls, whereas the sediments dip about $30^{\circ}$ N. $35^{\circ}$ E. The sediments are folded and near Jackson Creek, west of Gogebic County Highway 519, they dip south at more than $45^{\circ}$; the sediments are more tightly folded than the enclosing volcanic rocks, which have northward homoclinal dips almost everywhere.

The sediments may be a western facies of the Jacobsville Sandstone. The Jacobsville Sandstone that is 


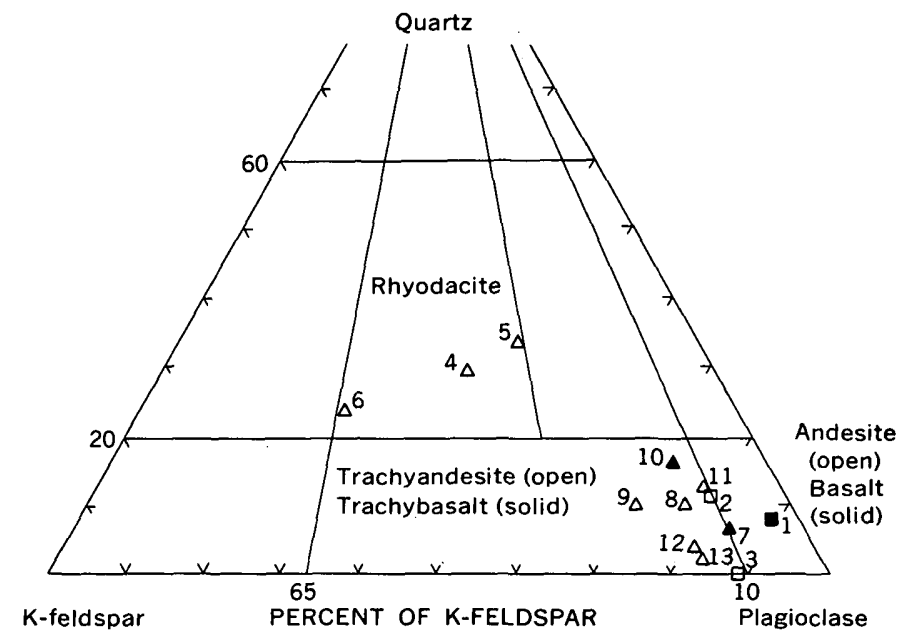

FIgURe 4.-Triangular diagram showing classification of volcanic rocks and proportions of normative quartz, K-feldspar, and plagioclase (recalculated to 100 percent) of some lower Keweenawan volcanic rocks of the Ironwood area, Michigan (classification of Streckeisen, 1967). Numbers keyed to table 2. Open symbols: $A b>A n$, color index $<40$. Solid symbols : $A n>A b$, color index $>40$. Squares: Siemens Creek Formation. Triangles: Kallander Creek Formation.

TABLE 3.-Comparison of lower and midale Keweenawan volcanic rocks in the Ironwood area, Michigan

Lower Keweenawan

Olivine basalt uncommon

Rhyodacite abundant

Ophitic rocks absent

Aphanitic rocks common

Large feldspar phenocrysts: : conspicuous, tend to be in clots.

Detrital rocks uncommon -..- Detrital rocks common.

Forms large prominent hilly Forms discontinuous hills and areas.

Exposures fairly common -.-- Exposures relatively uncommon.

Aeromagnetic anomalies gen- Aeromagnetic anomalies genererally more than 3,000 gammas.

Remanent magnetic field (cor- Remanent magnetic field (corrected for dip) has reversed rected for dip) has normal polarity, except in basal rocks.

moderately well indurated (some well enough to have been quarried for building stone) is composed of quartz sandstone and conglomerate. The Jacobsville is unconformable on lower Keweenawan rocks east of Lake Gogebic and at Sturgeon Falls in Houghton County, Mich. The Jacobsville apparently does not contain detritus of iron-formation; none is described in published papers, and I have not seen iron-formation in the outcrops I have examined. Thus the sparse data suggest the sediments of Jackson Creek are a western facies of the Jacobsville but do not preclude that the sediments might be part of a different stratigraphic unit.

The Jacobsville Sandstone has been interpreted as being younger than the middle Keweenawan rocks.
This interpretation was based on an incomplete understanding of Keweenawan stratigraphy. When the lower and middle Keweenawan volcanic rocks were not distinguished, the lower Keweenawan rocks were interpreted as a fault-repeated part of the middle Keweenawan rocks and, consequently, the unconformity between the Jacobsville sedimentary rocks and the lower Keweenawan volcanic rocks was used to demonstrate that the Jacobsville is younger than the middle Keweenawan rocks. The Jacobsville is not known to overlie any middle Keweenawan rocks, and it is beneath middle Keweenawan rocks at several places. Where exposed adjacent to the middle Keweenawan rocks, the Jacobsville is concordant, whereas near, but not adjacent to the middle Keweenawan rocks, the attitudes of the Jacobsville and middle Keweenawan rocks differ. The difference in attitude has been part of the evidence that the Jacobsville is discordant beneath the middle Keweenawan rocks because of large displacement faulting; however, the differences may be related to internal deformation of the less competent sediments during the folding of all Keweenawan rocks in post-Freda time.

\section{Portage Lake Volcanics}

The Portage Lake Volcanics is a sequence of subareally deposited lava flows containing some sedimentary interbeds. It was named by White, Cornwall, and Swanson (1953) for lava flows, mostly basalt and olivine basalt, containing 3-8 percent interbedded sedimentary rocks on Keweenaw Point. The Portage Lake has a maximum thickness of about $13,000 \mathrm{ft}$ $(3,960 \mathrm{~m})$ in the Ironwood area and more than 15,000 ft. $(4,575 \mathrm{~m})$ in the Keweenaw Peninsula. The Portage Lake differs from the underlying Kallander Creek Formation in structural attitude, geographic distribution, residual magnetic polarity and orientation, metamorphic grade, and rock type (table 3). The Portage Lake includes the rocks described by Gordon (1907, p. 441-450) as "Division VIII. The Ophites." The relationship between the Portage Lake Volcanics and the nonmagnetic rocks that overlie the Kallander Creek Formation is not known. The width of the outcrop belt varies proportionately with dip of the middle Keweenawan rocks across the North Ironwood quadrangle, suggesting little change in thickness across the quadrangle.

The basalt and olivine basalt of the Portage Lake Volcanics are fine grained but are coarser grained than the rocks of the overlying unnamed formation. Most flows are medium dark gray or dark gray, but some are olive gray or brownish gray. The flow tops are commonly grayish red to grayish-red purple. A few 
flows and flow tops are moderate yellow green to pale green. The flows are generally nomporphyritic but a few flows contain plagioclase phenocrysts, generally less than $10 \mathrm{~mm}$ although some are $30 \mathrm{~mm}$ long. In the Ironwood area less than $20 \mathrm{ft}(6 \mathrm{~m})$ of most flows is exposed; the thickest measured flow is about $90 \mathrm{ft}$ thick $(27 \mathrm{~m})$. The flows in the Ironwood area are very poorly exposed. If the exposures are representative, the flows contain a smaller proportion of ophitic rocks and are thinner than the flows on Keweenaw Point, where 41 percent of the section has ophitic rock and about 37 percent of the rock occurs in flows more than $100 \mathrm{ft}(30 \mathrm{~m})$ thick (White, 1960, p. 368).

The basalts of the Portage Lake Volcanics are generally holocrystalline with either intergranular or ophitic texture, but a few have intersertal texture. Lath-shaped plagioclase ranging from $\mathrm{An}_{55}$ to $\mathrm{An}_{20}$ and predominately 0.2 to $0.6 \mathrm{~mm}$ long constitutes one-half to two-thirds of the basalts. All feldspars contain epidote, and in some flows the plagioclase is almost completely altered to epidote. Augite, magnetite, ilmenite, and hematite are the other primary minerals. Vesicle fillings include epidote, chlorite, prehnite, pumpellyite, quartz, and albite.

Volcanic sandstone, conglomerate, and siltstone are interlayered with basalt. The only well exposed section of Portage Lake Volcanics is on the Montreal River, where a nearly $400-\mathrm{ft}(120-\mathrm{m})$ thickness of rock occurs at the top of the Portage Lake; about 40 percent of the rocks are sediments in layers $6 \mathrm{in}$. to $40 \mathrm{ft}(15 \mathrm{~cm}$ to $12 \mathrm{~m}$ ) thick. Sediments occur in all the thicker exposures, and some sediments form isolated exposures. The sediments are subangular to subrounded clasts of aphanitic to very fine grained felsic and intermediate volcanic rocks in nearly equal proportion. The sands include less than 10 percent quartz and feldspar. No clasts of rocks like the relatively coarse grained ophitic rocks of the Portage Lake flows were seen in the Ironwood area. All the rock types in the sediments occur in the lower Keweenawan formations. The lack of ophitic rock clasts suggests that the Portage Lake was not a source of the rocks in the sedimentary interbeds.

\section{Unnamed Formation}

The unnamed formation is a sequence of subaerially deposited lava flows interbedded with subordinate sedimentary rocks. It was first recognized in the Matchwood quadrangle by Johnson and White (1969, p. 5-8) but has not been named formally. It is distinguished from the conformably underlying Portage Lake by broad differences in rock type. The volcanic rocks of the unnamed formation are more felsic, finer grained, and include a greater proportion of porphyritic rock than those of the Portage Lake. The unnamed formation includes (1) the rocks described by Gordon (1907, p. 433-445) under the headings "Division VI. Amygdaloidal Melaphyres," and "Division VII. Chippewa Felsite," and (2) the uppermost rocks in "Division VIII. The Ophites."

Regionally, the unnamed formation is a volcanic pile or shield overlying the Portage Lake Volcanics, either interfingering with or overlapped by Copper Harbor Conglomerate (White, 1971, p. 9). The crest of the shield was about 15 miles $(25 \mathrm{~km})$ east of the Ironwood area. The formation has a stratigraphic thickness of about $8,000 \mathrm{ft}(2,400 \mathrm{~m})$ in the Ironwood area.

The volcanic rocks include basalts and olivine basalts, andesites, and felsites. Nearly all the exposed flows in the Ironwood area are porphyritic in contrast with those of the Portage Lake Volcanics, which have few porphyritic flows. In the better exposed rocks of the Matchwood quadrangle, porphyritic rocks are relatively common. (W. S. White, written commun., 1973). The flows range from 7 to $150 \mathrm{ft}$ (2 to $46 \mathrm{~m}$ ) thick. The ophitic flows average about $60 \mathrm{ft}(18 \mathrm{~m})$ in thickness, the nonophitic flows about $15 \mathrm{ft}(5 \mathrm{~m})$. The rocks are massive. Most tops are pahoehoe type and not very vesicular; few flows have scoriaceous or fragmental tops. Most flows are moderate to dark gray, but some are grayish red, grayish purple, dusky blue, light brownish gray, and pale red. A few flows contain brown oxidation layers about 1-2 in. $(2-5 \mathrm{~cm})$ thick that generally parallel the flow tops.

Rocks of the unnamed formation which have ophitic texture contain from 46 to 60 percent plagioclase feldspar ranging from sodic labradorite to oligoclase, 10 to 25 percent clinopyroxene, 4 to 15 percent olivine pseudomorphs (but some flows contain none), and 4 to 20 percent opaque minerals. The matrix, which includes chlorite and epidote, amounts to 10 to 20 percent. The nonophitic rocks contain 50 to 66 percent oligoclase or andesine, 1 to 15 percent clinopyroxene, 10 to 30 percent opaques, and 10 to 20 percent matrix, which includes chlorite and epidote. A few nonophitic flows contain as much as 8 percent olivine psuedomorphs. The amygdule minerals include chlorite, epidote, quartz, chalcedony, calcite, laumontite, pumpellyite, prehnite, zoisite, and clinozoisite.

Sedimentary rocks of the unnamed formation composed of clasts of volcanic rocks comprise less than 5 percent of the total thickness of the formation's exposed rocks, but sediments probably form a much greater proportion of the total thickness of rocks of the unnamed formation. Sediments are exposed in exten- 
sive exposures although they are poorly exposed even where volcanic rocks are well exposed. Sedimentary rocks are the only ones exposed within broad magnetic minima, suggesting few flows are present. The sandstones are composed mostly of well-sorted rounded to subangular fragments of volcanic rocks, but also contain some feldspar and quartz. The conglomerates are composed of aphanitic and very fine grained blue, gray, red-purple, purple-gray and reddish-brown volcanic rocks, a few of which are porphyritic. The average pebble size is about $4 \mathrm{in}$. $(10 \mathrm{~cm})$. The pebbles and sand grains include some rocks like those of the Powder Mill Group and do not include volcanic rocks as coarse grained as those of the Portage Lake. In addition, no ophites were seen. Although ophitic rocks weather more readily than nonophitic rocks, the complete absence of ophitic rocks indicates an absence in the source terrain; the modern beaches of Lake Superior have many pebbles and cobbles of ophitic rocks. This suggests that the source of the volcanic detritus of the unnamed formation was the Powder Mill Group.

\section{STRUCTURE}

The cross section in figure 2 shows the relationship between the upper and lower Keweenawan rocks about 1 mile $(1.5 \mathrm{~km})$ west of the Black River in westernmost Michigan. Here the lower Keweenawan rocks dip much more steeply than the middle Keweenawan volcanic rocks. The dips of the lower Keweenawan rocks increase upsection from about $65^{\circ} \mathrm{N}$. to slightly overturned. The dips of the middle Keweenawan volcanic rocks decrease upsection from about $45^{\circ} \mathrm{N}$. to about $20^{\circ} \mathrm{N}$. The dips of the lower and middle Keweenawan rocks also differ regionally. The attitudes of the nonmagnetic rocks and their relationship to the middle Keweenawan volcanic rocks are not known. The section was constructed by projection of surface attitudes of volcanic rocks. Exposures of the lower and middle Keweenawan volcanic rocks are very sparse and the observed attitudes may not be representative. Considerable folding could exist in the lower and middle Keweenawan rocks and not be shown by the exposed rocks. In Wisconsin, west of the cross section (fig. 2), both the lower and middle Keweenawan rocks dip steeply; in Michigan, east of the cross section, the middle Keweenawan volcanic rocks generally dip steeply northward, whereas the lower Keweenawan rocks dip less steeply (lower Keweenawan rocks dip $15^{\circ}$ or less east of Lake Gogebic). The trends of the belts of lower and middle Keweenawan volcanic rocks do not change accordingly. The belts are parallel in
Wisconsin where the dips are nearly vertical, but in Michigan the belts generally diverge eastward.

\section{METAMORPHISM}

The lower Keweenawan rocks differ in metamorphic grade from place to place. In Michigan the lower Keweenawan rocks are chlorite facies and contain sparse actinolite replacing pyroxene. In Wisconsin, rocks collected at the base of the volcanic sequence on successive township lines show a change westward from chlorite facies to amphibolite facies near Mellen (hornblende replacing pyroxene). The middle $\mathrm{Ke}$ weenawan rocks are slightly metamorphosed to pumpellyite-epidote facies throughout the region. The uniformity of the metamorphic grade of the middle Keweenawan rocks compared to the regional change of the lower Keweenawan rocks suggests that the lower Keweenawan rocks were metamorphosed before the middle Keweenawan rocks were deposited.

\section{GEOPHYSICS}

The magnetic anomalies associated with the Powder Mill Group are much larger than those of the middle Keweenawan volcanic rocks. The magnetic data were analyzed by Elizabeth King (this issue). The magnetic susceptibilities of the rocks of both sequences are similar, but the orientations and polarities of the magnetic fields differ. The Powder Mill rocks have a south-seeking polarization after correction for dip; the middle Keweenawan rocks have a north-seeking polarization. The buried surface of the Powder Mill rocks slopes northward and the surface is more than $1 \mathrm{mi}$ deep where it is beneath the base of the middle Keweenawan volcanic rocks. The magnetic minimum on the profile (King, this issue) is caused by the top of the Powder Mill rocks. This minimum can be traced eastward on the regional aeromagnetic map (Zietz and Kirby, 1971) to about long. $88^{\circ} 33^{\prime} \mathrm{W}$.

The anomaly associated with the basal part of the Powder Mill Group is well defined. The anomalies on the regional map show the limits of lower Keweenawan volcanic rocks. Anomalies associated with the exposed volcanic rocks are narrow and linear. The anomalies east of $88^{\circ} 30^{\prime} \mathrm{W}$. are broad and lack pronounced linearity and closely spaced small amplitude changes. The magnetic anomalies suggest that east of $88^{\circ} 33^{\prime} \mathrm{W}$. and south of the middle Keweenawan volcanic rocks the lower Keweenawan rocks are absent or thin.

A Bouger gravity map (Bacon, 1966, fig. 3) shows a large negative anomaly that is almost coincident with Keweenaw Bay. The anomaly is comparable with 
the largest negative anomalies in the Northern Central States. Either no mafic rocks underlie the anomaly or the mafic rocks are very thin and deeply buried. Thus, gravity as well as magnetic data suggest that lower Keweenawan volcanic rocks do not occur east of about $88^{\circ} 35^{\prime} \mathrm{W}$. and may not occur north of about $46^{\circ} 50^{\prime} \mathrm{N}$.

The linear magnetic anomalies in Baraga County are caused by dikes having a lower Keweenawan paleomagnetic field direction. The anomalies are superimposed on some of the magnetic anomalies of the Powder Mill Group, suggesting that the dikes are younger than the oldest Powder Mill flows.

\section{BASIN OF DEPOSITION}

The Powder Mill rocks probably were deposited in a basin that was south of their outcrop belt. This inference was made from the following evidence:

1. The dips of the lower Keweenawan and older layered rocks diverge or fan southward; that is, dips of the uppermost lower Keweenawan rocks are vertical to slightly overturned, and the northward dip of each older formation is slightly less than that of the overlying formation. Sparse published data show similar dip relations to the east and west of the type area (Van Hise and Leith, 1911, pl. 5, 6, 8, 10, 12). The fanning of dips is explained as the result of the area's continued subsidence to the south during deposition. An alternate interpretation is that the fanning is principally due to folding; however, the persistence of steep dips and the small differences in dips of different stratigraphic units require a nearly horizontal fold axis extending more than 50 miles $(80 \mathrm{~km})$. The older rocks to the south, in the Ironwood area, do not give evidence of such a fold axis. Instead, the whole succession seems to have tilted as one large block with little internal deformation.

2. Dikes that occur in pre-Keweenawan rocks have been assumed to be feeders for the Keweenawan flows, but only rarely do dikes cut the flows. Most dikes are Precambrian W, and some are Precambrian $\mathrm{X}$. One of the dikes that cuts the flows was tested for magnetic polarity by Books who found that it has a lower Keweenawan residual magnetic field (K. G. Books, oral commun., 1971).

3. Lower Keweenawan and older rocks provide much, if not all, of the detritus of the middle and upper Keweenawan sedimentary rocks (Hubbard, 1972). Types of rock that occur only in the Powder Mill Group are incorporated in the upper Keweenawan sedimentary rocks, whereas types that occur only in the middle Keweenawan rocks were not observed, suggesting that while the Powder Mill Group was eroded, the middle Keweenawan rocks were protected from erosion. Sedimentary structures (Hamblin and Horner, 1961) show that the source for the middle and upper Keweenawan sedimentary rocks was south of the outcrop belt. Thus, a terrane of lower Keweenawan and older rocks probably was exposed and eroded during middle and late Keweenawan time. The middle and upper Keweenawan sedimentary rocks range from 6,000 to $20,000 \mathrm{ft}(1,800-6,000 \mathrm{~m})$ in thickness and extend more than 125 miles $(200 \mathrm{~km}$ ) along strike. The volume of sediment is comparable to the volume of a large mountain range, and the volume of the source rocks must have been larger.

\section{REFERENCES CITED}

Aldrich, H. R., 1929, The geology of the Gogebic Iron Range of Wisconsin: Wisconsin Geol. and Nat. History Survey Bull. 71, Econ. Series 24, 279 p.

Bacon, L. O., 1966, Geologic structure east and south of the Keweenaw Fault on the basis of geophysical evidence, in The earth beneath the continents: Am. Geophys. Union Geophys. Mon. 10, p. 42-55.

Balsley, J. R., Jr., James, H. L., and Wier, K. I., 1949, Aeromagnetic surveys of parts of Baraga, Iron, and Houghton Counties, Michigan, with preliminary geologic interpretation: U.S. Geol. Survey Geophys. Inv. Map.

Books, K. G., White, W. S., and Beck, M. E., Jr., 1966, Magnetization of Keweenawan gabbro in northern Wisconsin and its relation to time of intrusion, in Geological Survey research 1966: U.S. Geol. Survey Prof. Paper 550-D, p. D117-D124.

Dutton, C. E., and Bradley, R. E., 1970, Lithologic, geophysical, and mineral commodity maps of Precambrian rocks in Wisconsin : U.S. Geol. Survey Misc. Geol. Inv. Map I-631.

Fritts, C. E., 1969, Bedrock geologic map of the MareniscoWatersmeet area, Gogebic and Ontonagon Counties, Michigan : U.S. Geol. Survey Misc. Geol. Inv. Map I-576, scale $1: 48,000$.

Gordon, W. C., 1907, A geologic section from Bessemer down the Black River : Michigan Geol. Survey Rept. 1906, p. 397507.

Hamblin, W. K., and Horner, W. J., 1961, Sources of the Keweenawan conglomerates of northern Michigan: Jour. Geology, v. 69, no. 2, p. 204-211.

Hubbard, H. A., 1972, Source of pebbles of volcanic rocks in the middle and upper Keweenawan conglomerates of northern Michigan : Jour. Geology, v. 80, p. 627-629.

Irving, R. D., 1883, The copper-bearing rocks of Lake Superior : U.S. Geol. Survey Mon. 5, 464 p.

Johnson, R. F., and White, W. S., 1969, Preliminary report on the bedrock geology and copper deposits of the Matchwood quadrangle, Ontonagon County, Michigan: U.S. Geol. Survey open-file rept., $31 \mathrm{p}$. 
Schmidt, R. G., 1972, Geology of Precambrian rocks, IronwoodRamsay area, Michigan: U.S. Geol. Survey open-file rept., $17 \mathrm{p}$.

Snelgrove, A. K., Seaman, W. A., and Ayres, V. L., 1944, Strategic minerals investigations in Marquette and Baraga Counties, 1943: Michigan Geol. Survey Prog. Rept. 10, p. 16.

Streckeisen, A. L., 1967, Classification and nomenclature of igneous rocks: Neues Jahrb. Mineralogic Abh., v. 107, no. 2, p. 144-214.

Trent, Virgil, 1973, Geologic map of the Marenisco and Wakefield NE quadrangles, Gogebic County, Michigan: U.S. Geol. Survey open-file rept.

Van Hise, C. R., and Leith, C. K., 1911, The geology of the Lake Superior region: U.S. Geol. Survey Mon. 52, 626 p.

White, W. S., 1960, The Keweenawan lavas of Lake Superior an example of flood basalts: Am. Jour. Sci., v. 258-A (Bradley volume), p. $367-374$
1966, Tectonics of the Keweenawan basin, western Lake Superior region: U.S. Geol. Survey Prof. Paper 524-E, 23 p.

1971, Geologic setting of the Michigan Copper District: Soc. Econ. Geologists, Guidebook for field conference, Michigan Copper District, Sept. 30-Oct. 2, 1971, Michigan Technol. Univ. Press, 82 p.

1972 , The base of the upper Keweenawan, Michigan and Wisconsin: U.S. Geol. Survey Bull. 1354-F, 23 p.

White, W. S., Cornwall, H. R., and Swanson, R. W., 1953, Bedrock geology of the Ahmeek quadrangle, Michigan: U.S. Geol. Survey Geol. Quad. Map GQ-27.

Zietz, Isidore, and Kirby, J. R., 1971, Aeromagnetic map of the western part of the Northern Peninsula, Michigan, and part of northern Wisconsin: U.S. Geol. Survey Geophys. Inv. Map GP-750, $1: 250,000$ scale. 


\title{
A TYPICAL CROSS SECTION BASED ON MAGNETIC DATA OF LOWER AND MIDDLE KEWEENAWAN VOLCANIC ROCKS, IRONWOOD AREA, MICHIGAN
}

\author{
By ELIZABETH R. KING, Reston, Va.
}

\begin{abstract}
A north-trending aeromagnetic profile of a sequence of east-striking Keweenawan volcanic rocks near Ironwood, Mich., can be matched to a calculated profile over a model consisting of a series of dipping layers. (The dips were those measured by $H$. A. Hubbard along the north-trending valley of the Black River.) Remanent and induced magnetizations of 39 oriented cores from the Black River valley were determined by K. G. Books; felsite from Chippewa Hill and basalt from Algonquin Falls of middle Keweenawan age have normal Keweenawan magnetization and lower Keweenawan Powder Mill rocks have reverse magnetization. In the model these magetizations were assigned to 26 layers which alternated with very weakly magnetized layers. The best match of the calculated composite anomalies of remanent and induced magnetization and the aeromagnetic profile occurs if a deeper block of steeply dipping Powder Mill rocks is assumed to underlie the middle Keweenawan flows.
\end{abstract}

The Ironwood area is particularly well suited for study by magnetic methods. The Keweenawan volcanic rocks produce well-defined magnetic anomalies which follow key units along strike. The persistence of the anomalies in successive magnetic profiles is shown in figure 1. The aeromagnetic maps of the area (Philbin and Vargo, 1966a, b) show a strikingly linear east-west trend which enables a geologist to map the sequence of flows that dip northward toward Lake Superior in spite of few outcrops. Individual magnetic highs can be traced for several miles with little variation in amplitude and with only slight offsets where faults cut the sequence. The regularity of the anomalies shows that the magnetic properties of the rocks are generally uniform along strike but differ considerably from layer to layer.

The Keweenawan volcanic rocks have, in addition to a moderately high magnetic susceptibility, a strong remanent magnetization which was acquired when they cooled. The lower part of the section, the Powder Mill. Group, has a remanent direction which is nearly opposite to that of the Portage Lake Volcanics and other members of the sequence above the Powder Mill (Books, 1968). These two different directions of magnetization are the main reason that the anomalies originating from the volcanic: flows of the Powder Mill
Group are much greater in amplitude than those of the rest of the section.

In order to obtain more information on the geologic relationships at depth, a typical magnetic profile was analyzed. The profile was one of the aeromagnetic profiles from which the contoured maps (Philbin and Vargo, 1966a, b) were compiled. The flightpaths were spaced one-half mile $(0.8 \mathrm{~km})$ apart and flown northsouth at approximately $500 \mathrm{ft}(150 \mathrm{~m})$ above the ground. The selected profile (fig. 2) was located along the valley of the Black River, which traverses the entire section and provides the most complete information available on the lithology and attitudes of the rocks.

A very large magnetic anomaly is associated with the Powder Mill Group. To the north, a very regular sequence of smaller magnetic highs is associated with exposed or near-surface rocks of the Portage Lake Volcanics, which underlie the "unnamed formation." Smooth magnetic profiles are associated with the relatively nonmagnetic clastic rocks of the Copper Harbor Conglomerate at the north and with the middle Precambrian sedimentary rocks upon which the Keweenawan volcanic rocks accumulated to the south. Two small, sharp magnetic highs just south of the base of the Keweenawan probably are caused by magnetic rock at the base of the Tyler Formation and by stockpiled iron ore or by mine buildings. The underlying Ironwood Iron-formation, which might be assumed to cause an anomaly, is nonmagnetic where crossed by the profile. Between the outcrops of lower and middle Keweenawan volcanic rocks, the magnetic profile is a long, smooth slope, which suggests the presence of clastic rocks or nonmagnetic igneous rocks. The glacial drift is very thick here; wells penetrate more than 200 $\mathrm{ft}(60 \mathrm{~m})$ of drift before reaching Keweenawan volcanic rocks. The lowest point on the magnetic profile over the Keweenawan rocks is caused by rock that occurs some distance north of the base of Portage Lake Volcanics.

A geologic model was constructed to conform to these magnetic constraints. The calculations were greatly 

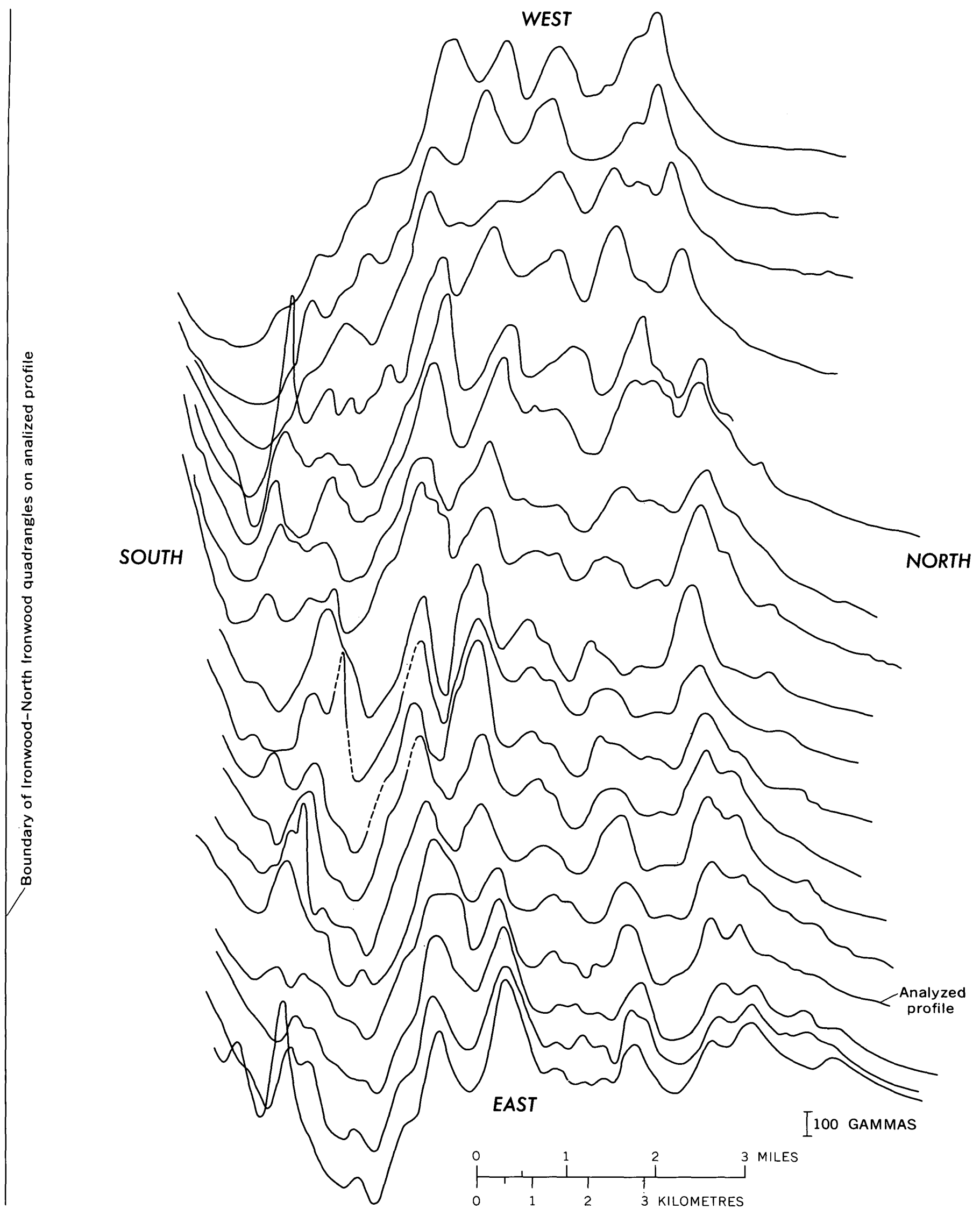

Figure 1.-Successive aeromagnetic profiles across the North I ronwood quadrangle, Michigan. The north-south flightpaths are at one-half mile intervals. Lines dashed where data were not recorded. The alinement of magnetic highs and lows shows that anomalies are persistent across the quadrangle. 
KING

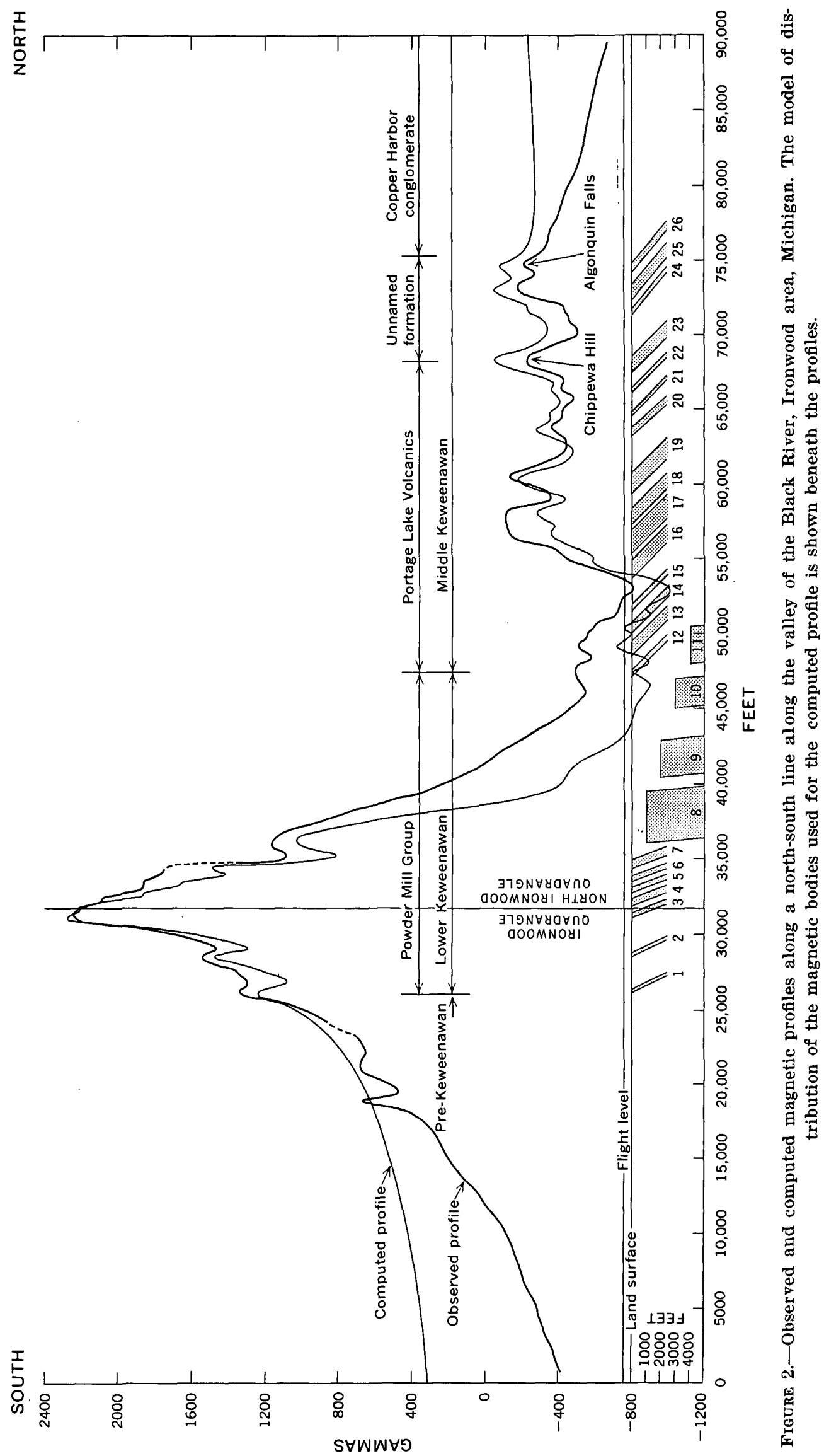


simplified because both the structure and the associated magnetic pattern are virtually linear, the profile being normal to the strike, so that a two-dimensional approach was possible. The model consists of a series of dipping layers; the dips were measured on the rocks exposed along the Black River (Hubbard, this issue). The number and thickness of the layers were determined by the number of recognizable magnetic anomalies and the width between their inflection points. Magnetic properties of 32 oriented cores from the Powder Mill rocks and 7 oriented cores from the Chippewa Hill felsite and Algonquin Falls basalt of the unnamed formation were determined by K. G. Books, U.S. Geological Survey.

The basalt cores from Algonquin Falls were found to have an average remanent magnetization of $7.5 \times 10^{-4} \mathrm{cgs}$ units with a declination of $269.7^{\circ}$ and an inclination of $40.1^{\circ}$. This is the orientation of the remanence of the rocks in their present tilted position. The magnetization of $7.74 \times 10^{-4} \mathrm{cgs}$ units induced by the present field is nearly the same magnitude as the remanence; the remanence, however, is nearly perpendicular to the plane of the airborne detector, which is oriented in the direction of the Earth's magnetic field. Most of the anomaly, therefore, is produced by the induced magnetization. The felsite cores from Chippewa Hill have a remanent magnetization of $8.1 \times 10^{-4} \mathrm{cgs}$ units, a declination of $257.5^{\circ}$, an inclination of $35.2^{\circ}$, and an induced magnetization of $11.1 \times 10^{-4} \mathrm{cgs}$ units; they, therefore, are similar in magnetic properties to the Algonquin Falls basalt cores. The Powder Mill cores have an average remanence of $49.4 \times 10^{-4} \mathrm{cgs}$ units, a declination of $10.6^{\circ}$, an inclination of $354.3^{\circ}$ or $5.7^{\circ}$ above the horizontal, and an induced magnetization of $18 \times 10^{-4} \mathrm{cgs}$ units. The remanence of the Powder Hill rocks is in nearly the same plane as the detector and generates a very large anomaly having a peak at the south edge, whereas the induced magnetization contributes relatively little to the anomaly.

In calculating the magnetic profile produced by the model, the layers were assumed to extend downward to infinity. The ertor introduced by this assumption is relatively small because the bulk of the anomaly is produced by the part of the layers closest to the detector. The calculations were performed by the U.S. Geological Survey's IBM 360-65 computer using a program which computes the total anomaly produced by both remanent and induced magnetization at the detector level. The total anomaly was calculated at 900 points.

The model and the computed profile are shown in figure 2. The similarity of the computed and observed profiles for the section from layers 16 to 26 is close in view of the fact that the magnetization of the Chip- pewa Hill felsite cores had to be used for all the layers of the model south of the Algonquin Falls basalt sequence. A better fit might have been obtained if magnetic-property data had been available for the rocks causing the anomalies over layers 17 and 18, which appear in the observed profile to have a stronger magnetization than the other layers in the sequence. In order to fit the high anomaly over the exposed Powder Mill rocks, it was necessary to consider the sequence as a number of thin layers having alternating strong and weak magnetization. Otherwise the computed anomaly falls off much too sharply to the north. The long smooth slope over the drift-covered area north of the exposed Powder Mill rocks suggests that magnetic rocks are deeply buried in this area, for calculations show that a profound low would appear just north of layer 7 if the magnetic rocks were missing. If the upper surface of the Powder Mill rocks slopes downward to the north under a thickening wedge of nonmagnetic rocks, for example clastic rocks, a smooth magnetic slope with a rather rounded anomaly over the unit farthest south would result. The model represents this section of buried Powder Mill rocks by a series of steeply dipping layers (8-11) at ever-increasing depths. The flat tops shown were for convenience in making the calculations rather than for representing the actual surface and do not significantly change the results. In reality, the layering is probably much more complex, like that of the exposed section, and the tops probably are sloping. If the Powder Mill rocks ended south of the southernmost mapped unit of middle Keweenawan rocks, model layer 12 , the lowest point on the profile would occur at this point instead of more than a mile to the north, and the anomalies over layers 12-15 would be much larger than those actually observed. The final model required Powder Mill rocks (layers 8-11) at depth under the southernmost layers (12-15) of middle Keweenawan as shown in figure 2. Therefore, a wedge of nonmagnetic material, about $7,000-8,000 \mathrm{ft}(2,130-2,440 \mathrm{~m})$ thick at the north, is indicated by the magnetic calculations.

\section{REFERENCES CITED}

Books, K. G., 1968, Magnetization of the lowermost Keweenawan lava flows in the Lake Superior area, in U.S. Geological Survey research 1968: U.S. Geol. Survey Prof. Paper 600-D, p. D248-D254.

Philbin, P. W., and Vargo, J. L., 1966a, Aeromagnetic map of parts of the Ironwood and Wakefield quadrangles, Gogebic County, Mich., and Iron and Vilas Counties, Wis.: U.S. Geol. Survey Geophys. Inv. Map GP-578.

1966b, Aeromagnetic map of parts of the Thomaston, Carp River, North Ironwood, and Little Girls Point quadrangles, Gogebic and Ontonagon Counties, Mich., and Iron County, Wis.: U.S. Geol. Survey Geophys. Inv. Map GP579. 


\title{
Jour. Research U.S. Geol. Survey \\ vol. 3 , No. 5, Sept.-Oct. 1975, p. 547-551 \\ REPLACEMENT BARITE DEPOSIT, SOUTHERN INDEPENDENCE MOUNTAINS, NEVADA
}

\author{
By KEITH B. KETNER, Denver, Colo.
}

\begin{abstract}
Allochthonous Devonian chert, metaquartzite, and greenstone in the Blue Basin quadrangle, southern Independence Mountains, Nevada, are mineralized with barite forming a deposit of possible commercial grade and size. Textural evidence indicates that the barite was deposited in the host rocks principally by replacement, to a lesser extent by a process involving displacement and expansion of the host-rock material, and to a very minor extent by fracture filling.
\end{abstract}

In the Singletree Creek and Blue Basin quadrangles (fig. 1), southern Independence Mountains, Ordovician to Devonian shaly and cherty rocks were thrust over Devonian and older carbonate rocks. The upper plate of this thrust is composed of several platelets separated

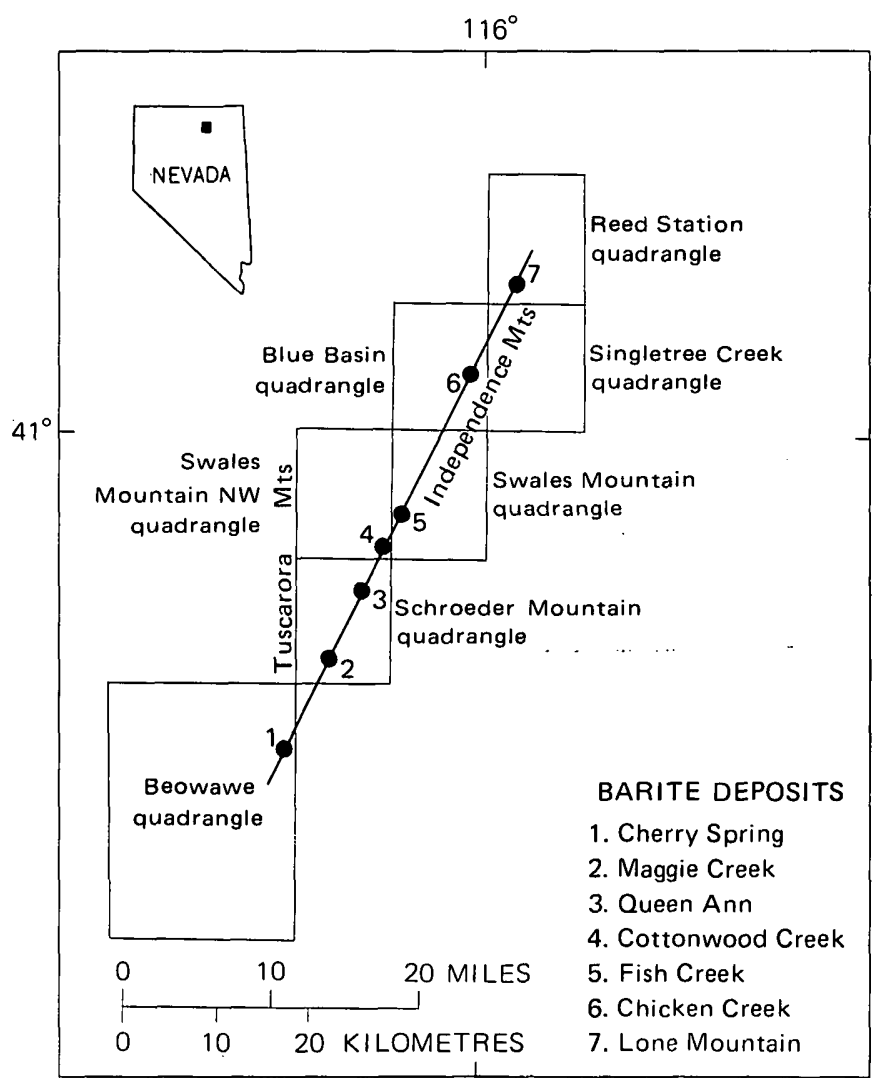

FIGURE 1.-Index map showing locations of U.S. Geological Survey quadrangles and alined barite deposits. by thrust faults (Lovejoy, 1959; Ketner, 1974). Devonian rocks in one of these platelets in the Chicken Creek drainage of the Blue Basin quadrangle are mineralized with barite. This deposit, herein called the Chicken Creek deposit, is the sixth in a remarkably straight alinement of seven known deposits in the southern Tuscarora and Independence Mountains (fig. 1). The mineralized unit, which strikes north and dips steeply west, is exposed intermittently in secs. 17, 20, and 29 , T. 37 N., R. 53 E. (fig. 2; and Ketner, 1974). It consists principally of bedded chert, recrystallized chert or metaquartzite, sandstone, limestone, and greenstone of intermediate to basic composition.

The chert is in beds a few centimetres thick separated by thin shale beds. Some of it is black finegrained radiolarian chert identical to that in allochthonous Devonian units elsewhere (Gilluly and Gates, 1965), but much of it has an unusual grainy texture in hand specimen. The grains are closely packed sporelike bodies of Tasmanites (R. M. Kosanke, oral commun., 1974) commonly found in marine beds of Devonian and younger age (fig. 3). Sporelike bodies of this type in the Devonian Woodruff Formation (Smith and Ketner, 1968) also have been identified as Tasmanites by J. M. Schopf (written commun., 1957). In places, the bedded chert has been recrystallized and bleached to form white medium-grained metaquartzite. Remnants of Tasmanites can be recognized in some of the incompletely recrystallized rock. The cause of recrystallization is not apparent. Only part of the chert and none of the other kinds of rocks are visibly affected. The sandstone is coarse grained, poorly sorted, and crossbedded. It is composed largely of detrital grains of bioclastic limestone and fossil fragments but includes grains of greenstone and, rarely, chert, quartz, and shale. The limestone is composed largely of bioclastic debris like that forming limestone clasts in the sandstone beds. The greenstone is a vesicular, evengrained rock composed largely of close-packed felted plagioclase laths (pilotaxitic texture) and lesser amounts of alteration products including calcite and chlorite (fig. 4). Calcite fills vesicles and veins and is 


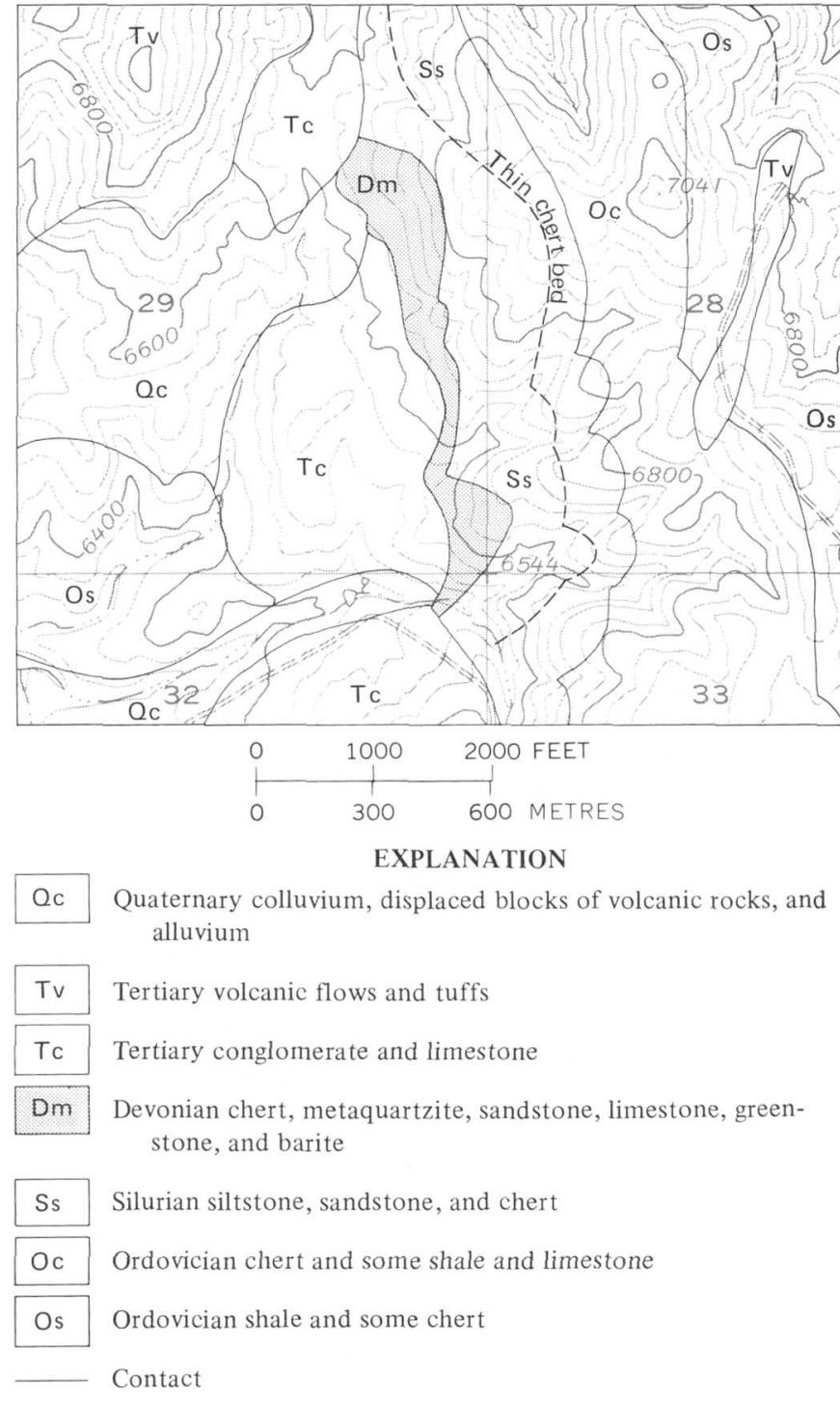

Figure 2.-Geologic map of parts of secs. 28, 29, 32, and 33, T. 37 N., R. 53 E., showing location of Devonian beds mineralized with barite. (Deposit 6 in fig. 1.) Base from U.S. Geological Survey Blue Basin topographic quadrangle, 1958.

disseminated in small grains. The greenstone is interlayered with crossbedded, coarse sandstone and black, bedded chert in units less than $1 \mathrm{~m}$ thick in one exposure. In another exposure it is closely associated with bioclastic limestone. Exposures are too poor to permit identification of pillow structures and it is impossible to determine whether the greenstone layers are extrusive flows or shallow sills.

Fragmental conodonts from sandstone in the map unit that includes the barite deposits indicate a latest Devonian age, according to Charles Sandberg. However, the Tasmanites-bearing beds in this unit are lithologically similar to Lower Devonian Tasmanites-bearing beds near the base of the Woodruff Formation

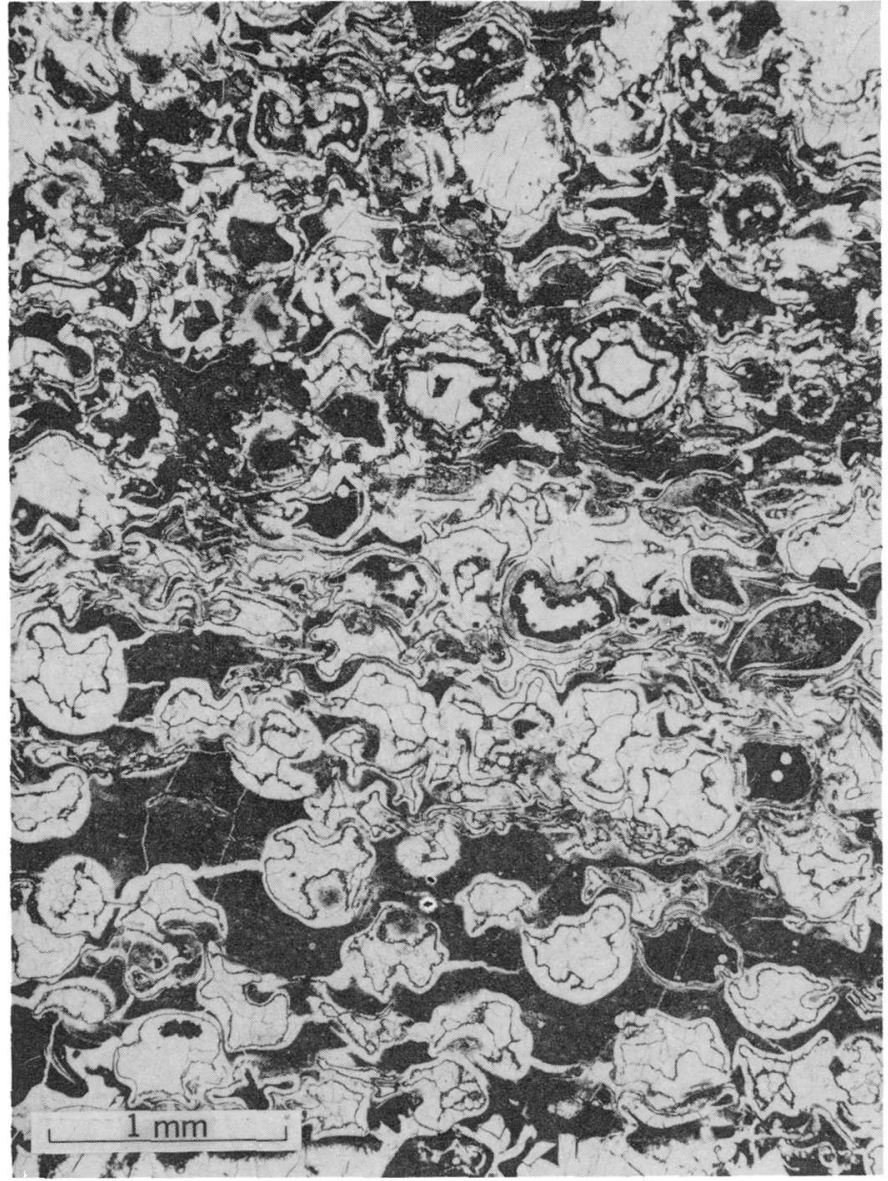

Frgure 3.-Thin section of chert showing sporelike bodies of Tasmanites filled with quartz and chalcedony (light). Extensive dark areas are organic cherty sediment. Thin dark septa are distorted original spore material. Uncrossed polarizers.

(Smith and Ketner, 1968). Considering the possibility that the fragmental conodonts may have been reworked, and uncertainty as to the age of the Tasmanites beds, the baritic map unit is regarded as probably of Devonian age. It could be younger, however.

Barite was seen only in sec. 29. The principal exposure is a prominent outcrop of white massive barite $950 \mathrm{~m}$ north-northwest from the southeast corner of sec. 29. Dark-gray barite is inconspicuously exposed about $100 \mathrm{~m}$ downslope to the west of this outcrop. A third exposure is $150 \mathrm{~m}$ north of the southeast corner of sec. 29. The third exposure consists of scattered loose pieces of barite and very inconspicuous small outcrops. Scattered small pieces of barite in the soil suggest that solid barite may underlie the surface among these exposures. Tertiary volcanic rocks, conglomerate, and limestone overlap the baritic Devonian rocks on the west. Quite possibly they conceal additional barite deposits. 


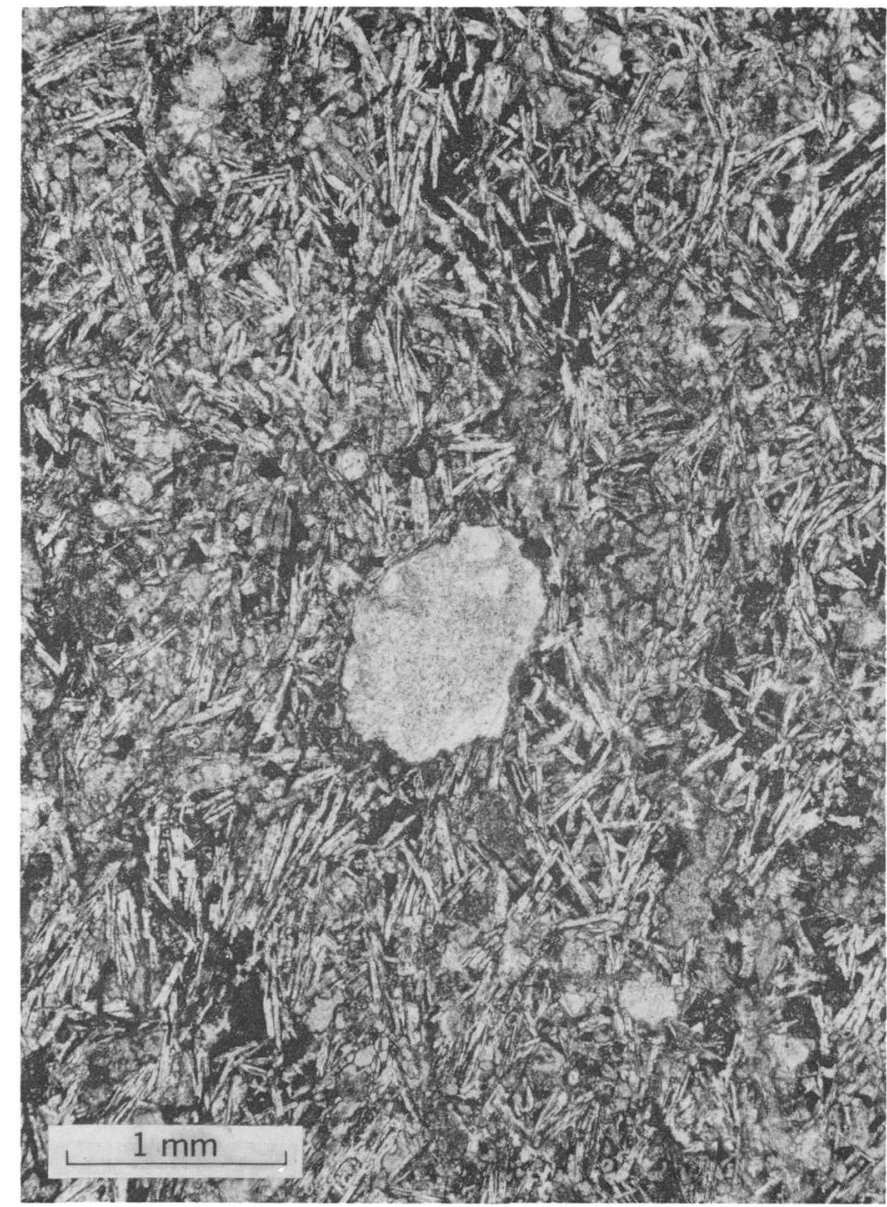

Figure 4--Thin section of greenstone showing felted plagioclase crystals and, in center, vesicle filled with carbonate. Uncrossed polarizers.

The Chicken Creek barite deposit is not of the bedded type. Barite of this deposit ranges from pure white massive rock resembling marble to dark-gray irregular mixtures of barite, white quartzite, black chert, and drab greenstone. The specific gravity of 23 samples of barite selected at random ranged from 2.9 to 4.4 and averaged 3.8. The white samples tend to have the highest specific gravity. If barite of similar quality underlies a large part of the area among the outcrops the deposit could be minable.

Abundant textural evidence indicates that the bulk of the Chicken Creek deposit was formed by replacement of host-rock material. Direct evidence of replacement is the transection of host-rock textures by blades and rosettes of barite in greenstone, chert, and quartzite (figs. 5, 6, 7). The results of all stages of this pervasive process can be seen-from rocks in which the barite forms only small isolated crystals to rocks that are composed almost wholly of interlocking crystals of barite with isolated interstitial remnants of the original host material.

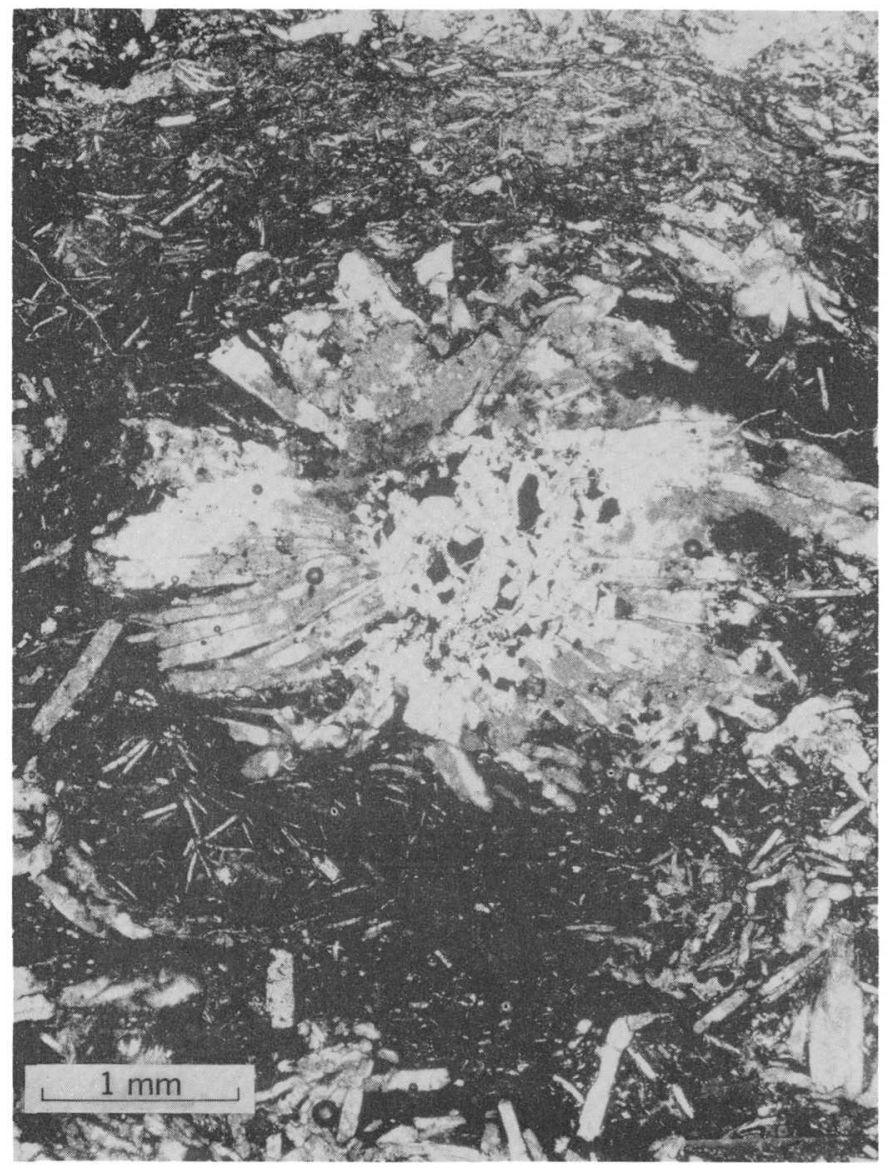

Figure 5.-Thin section of greenstone (dark with small gray and white laths) partly replaced by barite (rosette and large gray and white laths). Uncrossed polarizers.

A small part of the deposit apparently was formed by displacement rather than replacement of host-rock material. In some chert beds barite has crystallized in layers subparallel to the bedding and seems to have broken some of the beds apart by the force of crystallization (fig. 8).

A very small part of the deposit was formed by fracture filling (fig. 9).

Evidence relating to the time of mineralization is ambiguous. The disruption and displacement of some chert beds as shown in figure 8 suggest that barite was introduced immediately after deposition of the chert when the chert was still soft and overlain by only a thin cover of sediment, but this evidence conflicts with the following evidence which indicates barite was introduced after consolidation of host rocks.

Some of the chert was brittle at the time barite was introduced, inasmuch as quartz-filled fractures are offset by barite veins (fig. 9) and some chert apparently was recrystallized before barite was introduced (fig. 7). All but one (No. 2) of the deposits shown in figure 


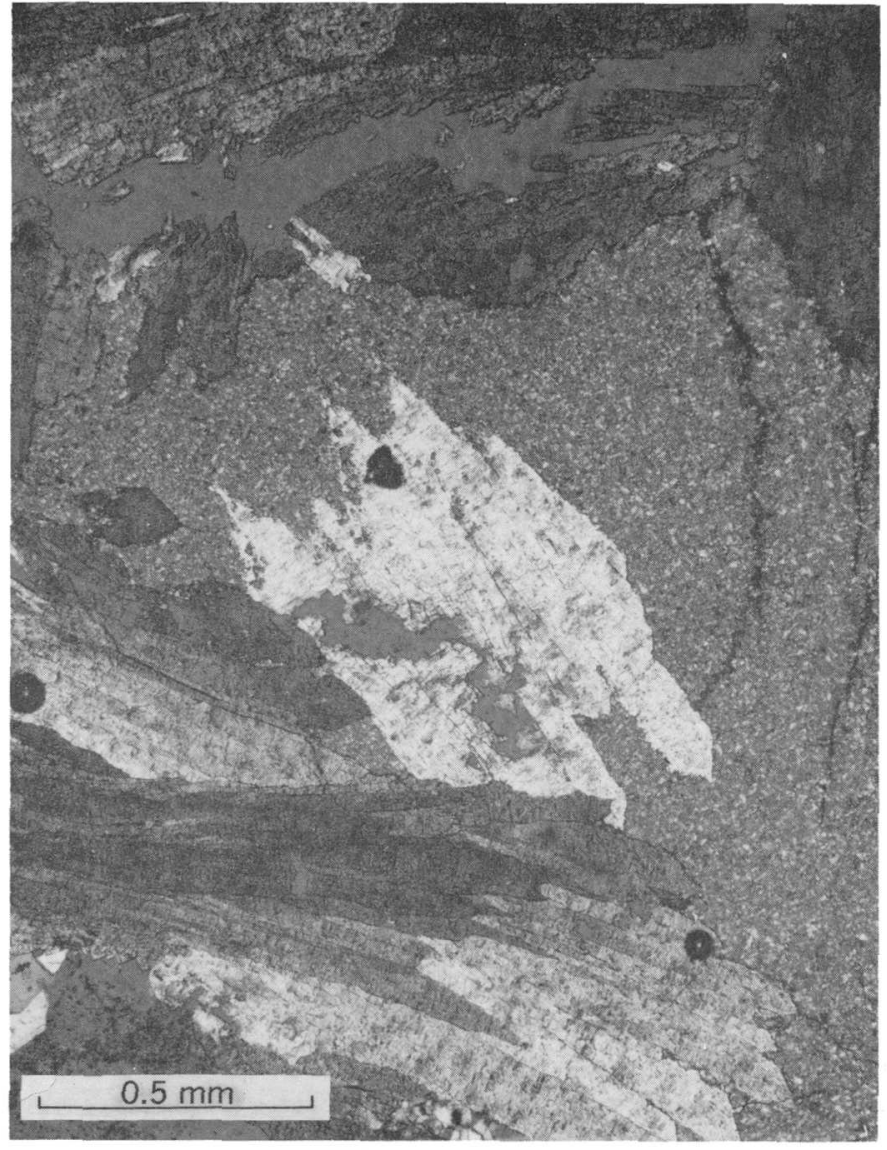

Figure 6.-Thin section of chert (fine-grained, speckled) partly replaced by barite (sheaves, gray or white). Crossed polarizers.

1 are in the upper plates of thrust faults having displacements of several kilometres. Had any of them been formed before thrusting it seems unlikely they would have come to rest in perfect alinement. Their present alinement, therefore, suggests that they were formed after the end of thrusting. The last known period of thrusting in this region was in Late Jurassic or Early Cretaceous time (Ketner and Smith, 1974).

\section{REFERENCES CITED}

Gilluly, James, and Gates, Olcott, 1965, Tectonic and igneous geology of the northern Shoshone Range. Nevada: U.S. Geol. Survey Prof. Paper 465, 153 p.

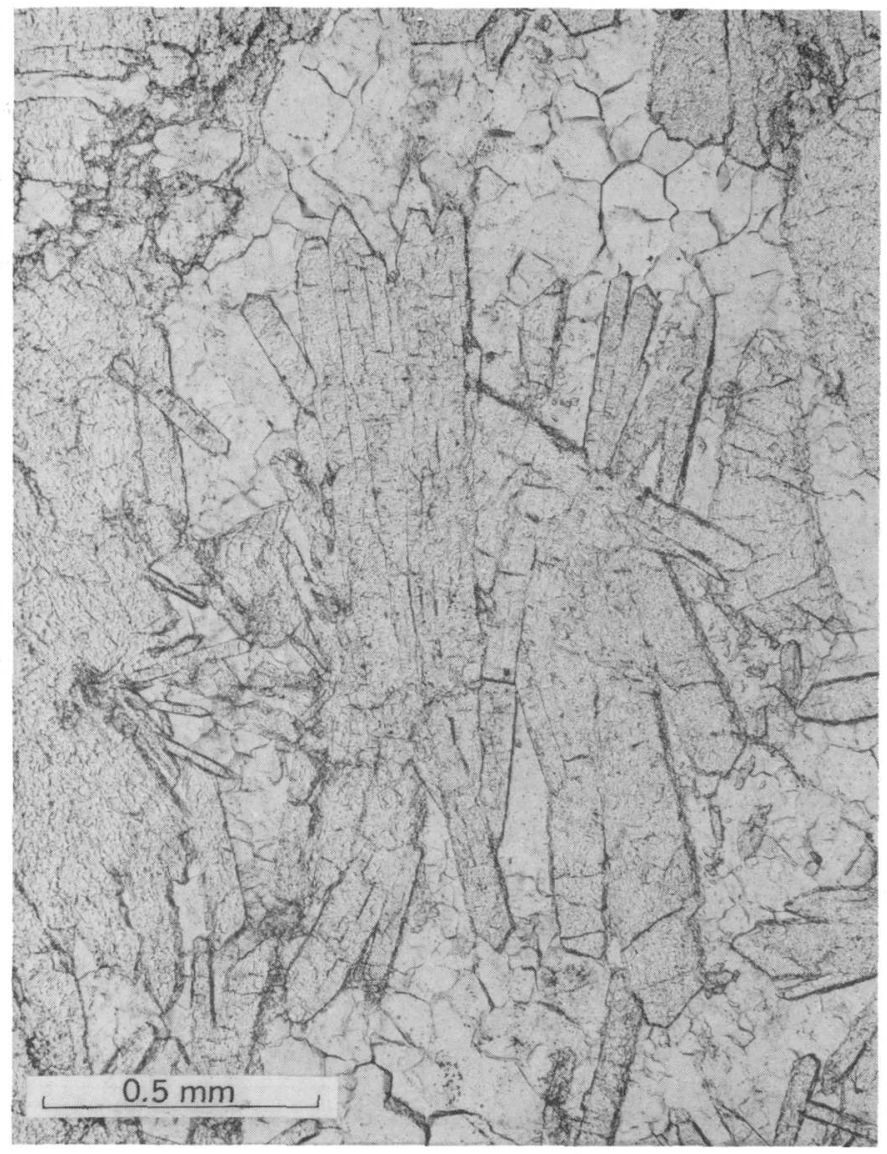

FIgURE 7.-Thin section of recrystallized chert (white mosaic of equant quartz grains) partly replaced by barite (gray laths). Uncrossed polarizers.

Ketner, K. B., 1974, Preliminary geologic map of the Blue Basin quadrangle, Elko County, Nevada: U.S. Geol. Survey Misc. Field Studies Map MF-559.

Ketner, K. B., and Smith, J. F., Jr., 1974, Folds and overthrusts of Late Jurassic or Early Cretaceous age in northern Nevada: U.S. Geol. Survey Jour. Research. v. 2, no. 4, p. 417-419.

Lovejoy, D. W., 1959, Overthrust Ordovician and the Nannie's Peak Intrusive, Lone Mountain, Elko County, Nevada: Geol. Soc. America Bull., v. 70, p. 539-564.

Smith, J. F., Jr., and Ketner, K. B., 1968, Devonian and Mississippian rocks and the date of the Roberts Mountains thrust in the Carlin-Pinon Range area, Nevada: U.S. Geol. Survey Bull. 1251-I, 18 p. 


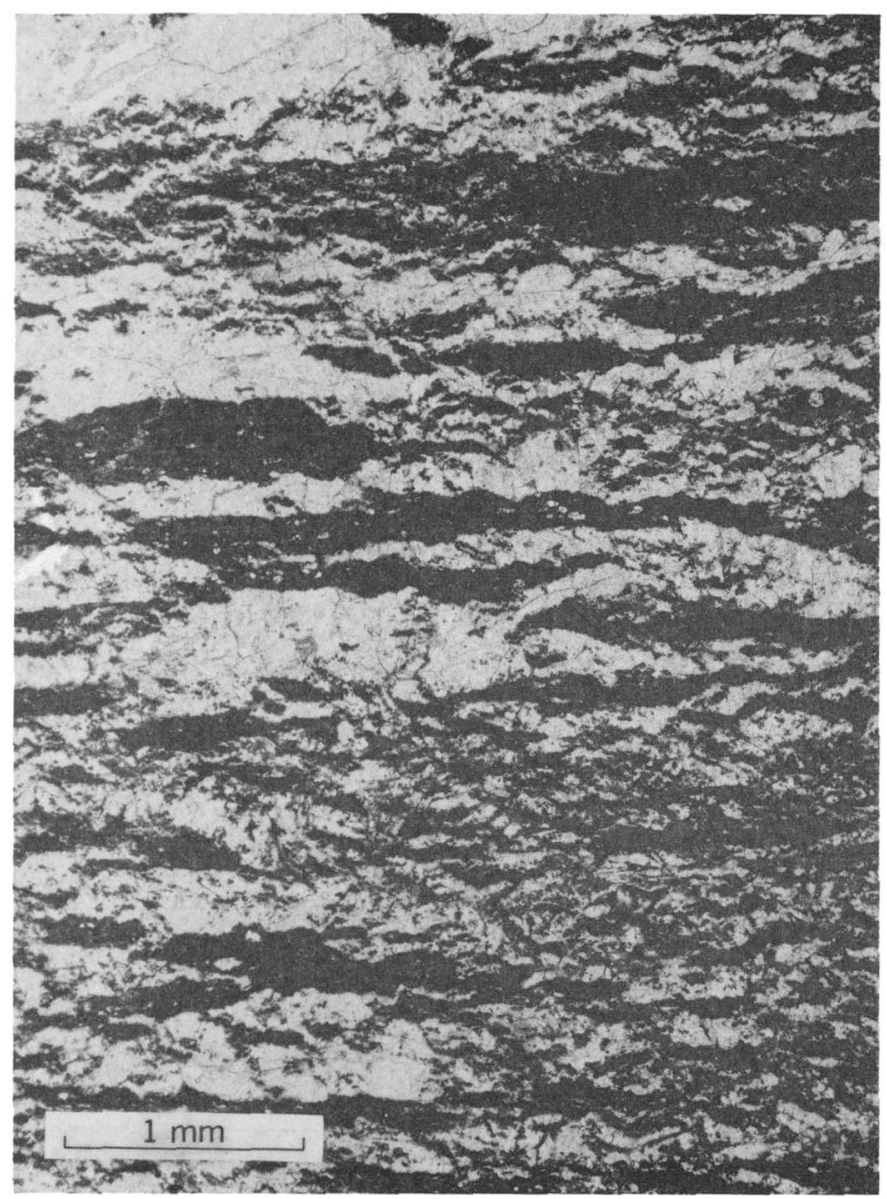

Figure 8.-Thin section of organic-rich chert (black) showing expansion of chert due to growth of barite (white) in veins roughly parallel to bedding. This relationship indicates that some barite grew within preexisting sediments under conditions of light confining pressure. Uncrossed polarizers.

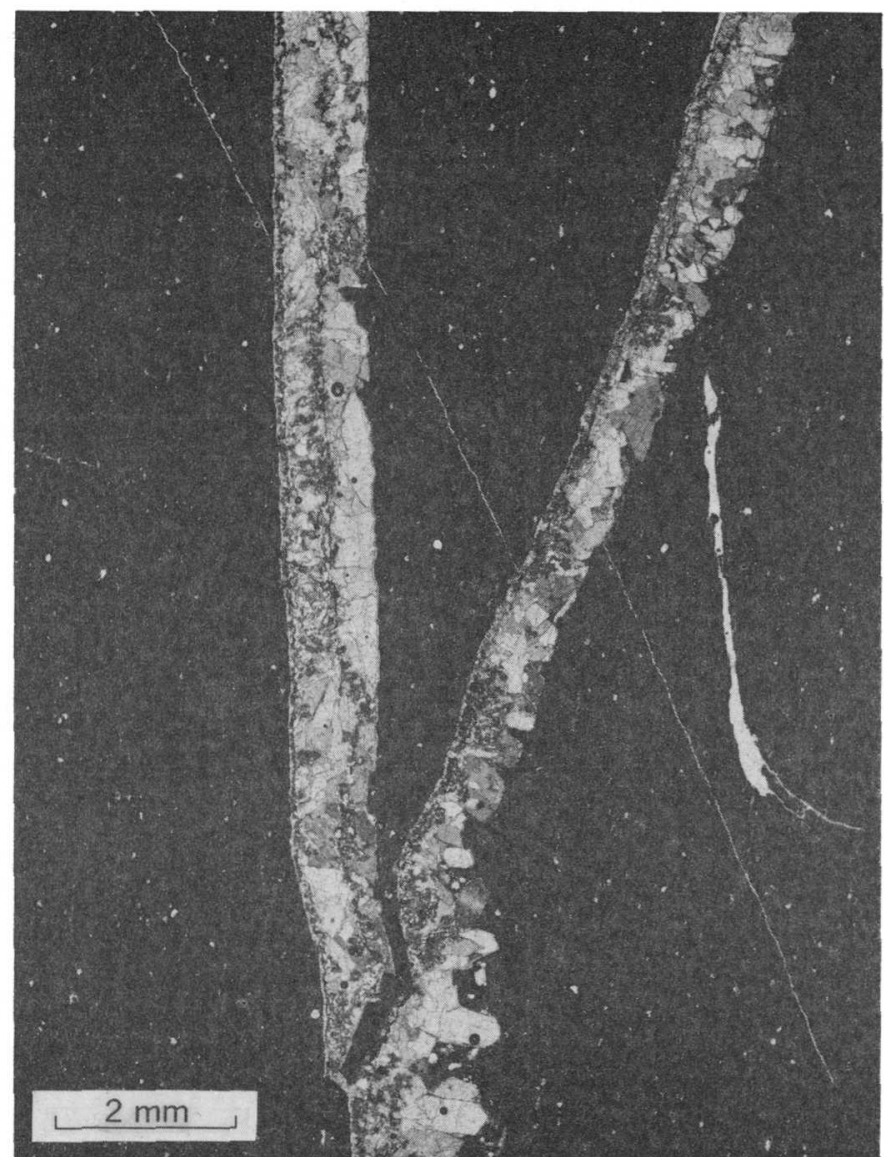

Figure 9.-Thin section of chert (dark) showing quartz vein (hairline, lower right to upper left) offset by younger barite vein (broad, gray and white). These relations indicate a history of lithification of chert, fracturing, introduction of quartz, fracturing, and, finally, introduction of barite. Uncrossed polarizers. 


\title{
DIAGENESIS OF MIOCENE SILICEOUS SHALES, TEMBLOR RANGE, CALIFORNIA
}

\author{
By K. J. MURATA and R. R. LARSON, \\ Meno Park, Calif., Reston, Va.
}

\begin{abstract}
Siliceous Monterey Shale and related shales of the Temblor Range, Calif., are subdivided into three depthcontrolled zones characterized by different forms of silica. These are, in descending stratigraphic order: (1) Biogenic opal zone, with remains of diatoms and other siliceous organisms, (2) diagenetic cristobalite zone, and (3) diagenetic quartz zone. Using the top of the youngest marine unit, the overlying Etchegoin Formation, as datum, the transition from biogenic opal to disordered cristobalite occurs within the Monterey Shale of Chico Martinez Creek at $-730 \mathrm{~m}$, and the ordered cristobalite-to-microquartz transition at about $-2,030$ $m$. Temperatures that prevailed at these transition depths while the sedimentary pile lay at the bottom of the sea are estimated at about $50^{\circ}$ and $110^{\circ} \mathrm{C}$, respectively. Diagenetic cristobalite manifests, downward through a $1,300-\mathrm{m}$ interval of section, a progressive decrease in its $d(101)$ spacing because of a gradual ordering of its internal structure through adjustments in the solid state. Diagenetic microquartz forms only from well-ordered cristobalite that provides the most appropriate concentration of dissolved silica for precipitation of microquartz. Scanning electron micrographs of the silica mineral in pores of rocks made up of disordered cristobalite show aggregates of well-formed bladed crystals, like those described from deep-sea cherts. The pore silica minerals in rocks made up of ordered cristobalite occur as dendritic growths of poorly formed stubby crystals, and the change in crystal habit could be an external expression of the internal ordering process.
\end{abstract}

The genesis of chert in the Miocene Monterey Shale and related shales of California was investigated by Bramlette (1946) through extensive field and laboratory work. He showed that metamorphism due to burial converted the diatomaceous shale first into "opaline" cristobalitic chert and porcelanite and finally into quartzose chert and porcelanite. At a few localities, such as Chico Martinez Creek in the Temblor Range, he found the entire diagenetic sequence of diatomaceous, cristobalitic, and quartzose shales exposed in a continuous stratigraphic section. We have applied techniques of $\mathrm{X}$-ray diffraction and scanning electron microscopy to samples from these localities to study in greater detail the progressive diagenetic changes.
The discovery of much chert in Miocene and older submarine sediments has been an unpleasant surprise to the Deep Sea Drilling Project (DSDP) because the chert greatly hinders the drilling of the sediments (Briggs, 1971; Deep Sea Drilling Project, 1973). The troublesome chert has been studied intensively (Rex, 1969; Calvert, 1971; Pimm and others, 1971; Berger and von Rad, 1972; Lancelot, 1973; among others), and the findings indicate that chert has formed through alteration of different metastable silicates and that its mineralogy is related to age, depth of burial, and nature of the host sediment. A widespread type of chert in submarine sediments is the one derived through alteration of biogenic opal in carbonatepoor environments, which is also the type characteristic of the Monterey Shale.

The purity of a carbonate-poor siliceous ooze is inversely related to the amount of terrigenous material that reaches the site of deposition (Gucluer and Gross, 1964; Calvert, 1966; Moore and others, 1973). Submarine diatomaceous sediments containing increasing amounts of terrigenous materials are classified into four semiquantitative categories under the names diatom ooze, clayey diatom ooze, diatom clay, and clay, according to McManus and others (1970). The field classification of comparable sediments in the Monterey Shale entails broader qualitative categories with the names diatomite, diatomaceous mudstone, and mudstone (Bramlette, 1946).

It is unlikely that mild diagenetic alteration would homogenize an originally variable siliceous sediment. Murata and Nakata (1974) suggested that diagenesis converts the purer diatomite layers into bedded chert and the less pure diatomaceous mudstone into porcelanite, thereby retaining in the converted rock much of the heterogeneity of the original sediment. Among deep-sea sediments, cristobalitic rocks comparable to porcelanites are called cristobalitic claystone (Zemmels and Cook, 1973).

The terms chert and porcelanite need to be defined here because some confusion exists as to their exact 
meaning. We follow Bramlette (1946) in our use of these terms:

"The name chert is applied to the relatively pure silica rocks of the Monterey formation that are dense and vitreous, regardless of whether they consist mainly of opal or mainly of chalcedony $* * *$."

"Porcelanite $* * *$ is adopted here for designating the silica-cemented rocks that are less hard, dense, and vitreous than chert. Such rock has minute pore spaces, which usually give it a dull or matte lustre resembling that of unglazed porcelain."

Accordingly, we subdivided diagenetically altered siliceous rocks in the field into chert and porcelanite on the basis of their texture and determined their mineralogy in the laboratory through X-ray diffraction. Both chert and porcelanite can be either cristobalitic or quartzose.

Acknowledgments.-Permission to examine the Monterey Shale on private lands was kindly granted by C. F. Twisselman of McKittrick and by officials of Johns Manville Products Corp. and of Grefco Inc. of Lompoc. For guidance on the stratigraphy of the beds we studied, we are indebted to Paul Land and J. C. Sullivan of the California Division of Oil and Gas and to several of our U.S. Geological Survey colleagues. We thank E. H. Bailey and D. W. Scholl for their very helpful reviews of the manuscript.

\section{SAMPLE LOCALITIES}

Most of the samples we studied were collected along Chico Martinez Creek and along a mountain road southwest of Taft (locs. 1 and 2, fig. 1) in the Temblor Range, where thick sections of Miocene siliceous shale are well exposed along creek valleys. Further details of the two localities are given later in the discussion of the silica mineralogy of the rocks. Supplementary material for a study of the earliest stages of chert formation was obtained from the active diatomite mines around Lompoc (loc. 3, fig. 1).

\section{METHODS OF LABORATORY INVESTIGATION}

The gross mineralogy of all samples was first established through X-ray diffractometry. For samples found to be cristobalitic, the $d(101) \mathrm{X}$-ray spacing of cristobalite was then determined by means of smears to which sufficient powdered quartz had been added to make the (10i1) peak of quartz roughly as intense as the (101) of cristobalite. Counting parameters were selected to make the generally broad (101) cristobalite peak as sharp as possible. The average of the forward and reverse scans from one peak to the other at $0.5^{\circ}$ per minute was considered a single determination, and

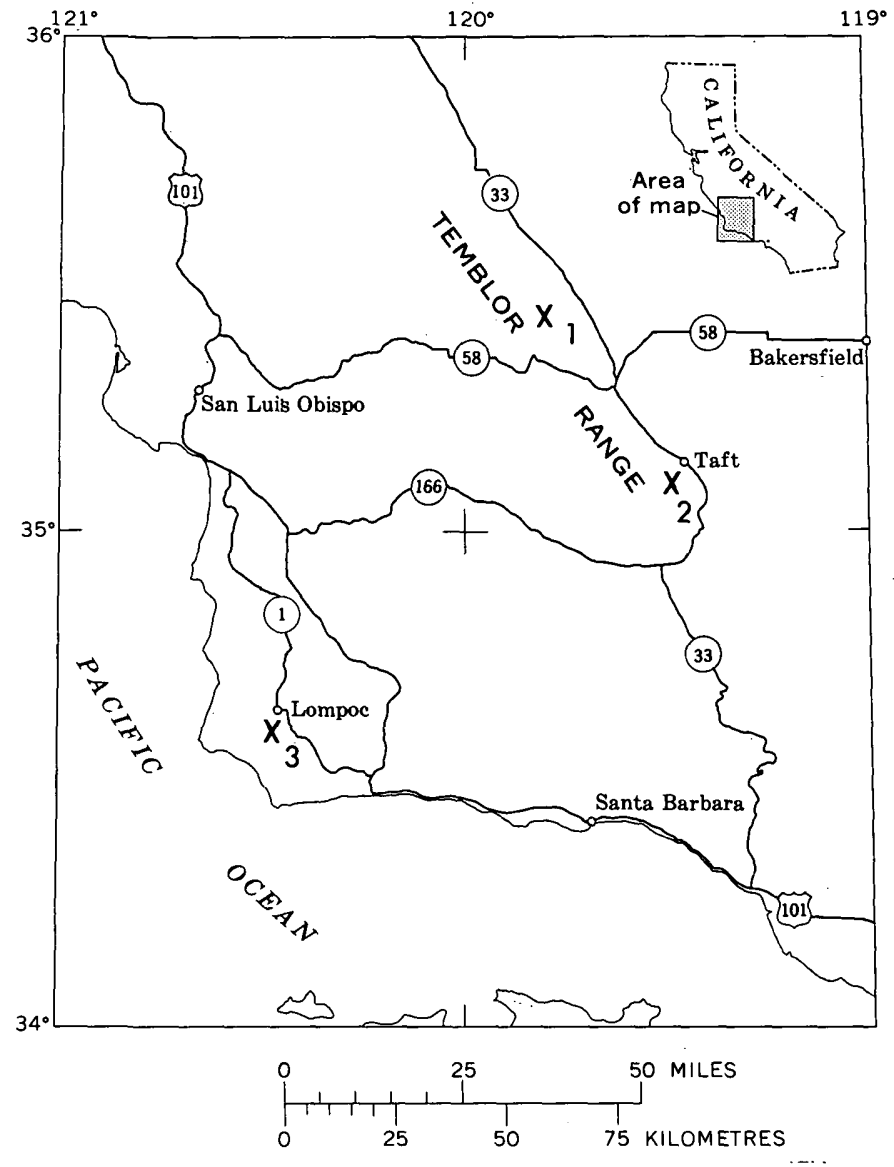

Figure 1.-Index map of part of California showing localities 1 (Chico Martinez Creek), 2 (Taft) in the Temblor Range, and 3 (Iompoc), where samples desrcibed in this report were collected. Details of locality 1 are given in figure 3 ; those of locality 2 , in figure 4 .

replicate determinations made on different days on several samples indicated an overall precision of $2 \sigma$ equal to $0.0052 \mathrm{~A}$.

Dry bulk densities of shales, cherts, and porcelanites were measured either by weighing samples that had been cut into blocks of known dimensions or by determining the loss of weight in water of irregular pieces spray-coated with acrylic plastic. Thin sections and powders of typical samples of shale, chert, and porcelanite were examined under the petrographic microscope to follow the transformation of diatom frustules into massive cryptocrystalline cristobalite and to correlate the structural ordering or "aging" of cristobalite with a progressive rise of average index of refraction.

For a more detailed morphological study, broken surfaces of chert and porcelanite were examined with the scanning electron microscope (SEM). Freshly broken surfaces were made conducting by coating with Au-Pd alloy in a vacuum evaporator provided with a sample spinner. Micrographs were taken at a tilt of 
$30^{\circ}$ using the secondary electron detector and a beam of $20 \mathrm{kV}$. Some problems occurred with charge accumulation and luminescence around microcavities in the specimens, presumably because of the difficulty of coating cavity interiors and because of the presence of fluorescent organic(?) matter in and around the cavities. Elemental composition of the phases was checked by an accompanying energy dispersive X-ray system.

Because the overall composition of the Monterey Shale is fairly well known (Bramlette, 1946), we have had analyzed only two samples of special interest, a diatomite and cristobalitic chert derived from it.

\section{BEGINNINGS OF CHERT}

The early stages of formation of chert in diatomite can be most easily studied in active diatomite mines around Lompoc (loc. 3, fig. 1). The minor amount of diagenetic chert that is present in the commercially mined material occurs as thin lenses and layers confined to certain stratigraphic horizons in beds of purest diatomite (Mulryan, 1936, p. 149). Less pure diatomaceous mudstone is virtually free of chert not only at Lompoc but elsewhere as well.

The compact first-formed chert (fig. 2A) yields a well-defined X-ray pattern of cristobalite of the type called lussatite (opal C'T) by Jones and Segnit (1971), whereas the unaltered diatom frustules of the host rock are amorphous to X-rays. Biogenic opal seems to be the only X-ray-amorphous silica in Monterey Shale, and we have found no chert comparable to some X-rayamorphous precious opals and hot-spring sinters.

Petrographic examination of the lenticular chert suggests that chert formed in layers of highly pure diatomite through dissolution of diatom frustules, deposition of cryptocrystalline cristobalite, and addition of silica from adjacent less pure diatomite. A continuation of the process enlarged the original lenses into progressively thicker and more persistent "beds" of cristobalitic chert, ranging in thickness from a few centimetres to a few metres (fig. $2 B$ ).

The gray layered chert, which contains cristobalite with $d(101)$ of $4.108 \mathrm{~A}$ and which is shown in figure $2 B$, and the host (and parental) diatomite were analyzed to determine the compositional relation between the two rocks (cols. 2 and 1 , respectively, table 1 ). The composition of chert (col. 2) can be closely approximated (col. 3) by adding 1.70 parts of hydrated silica of reasonable composition to 1 part of host diatomite. Thus, chemical data and petrographic features of the rocks both suggest an alteration-accretion mechanism for converting diatomite into cristobalitic chert.
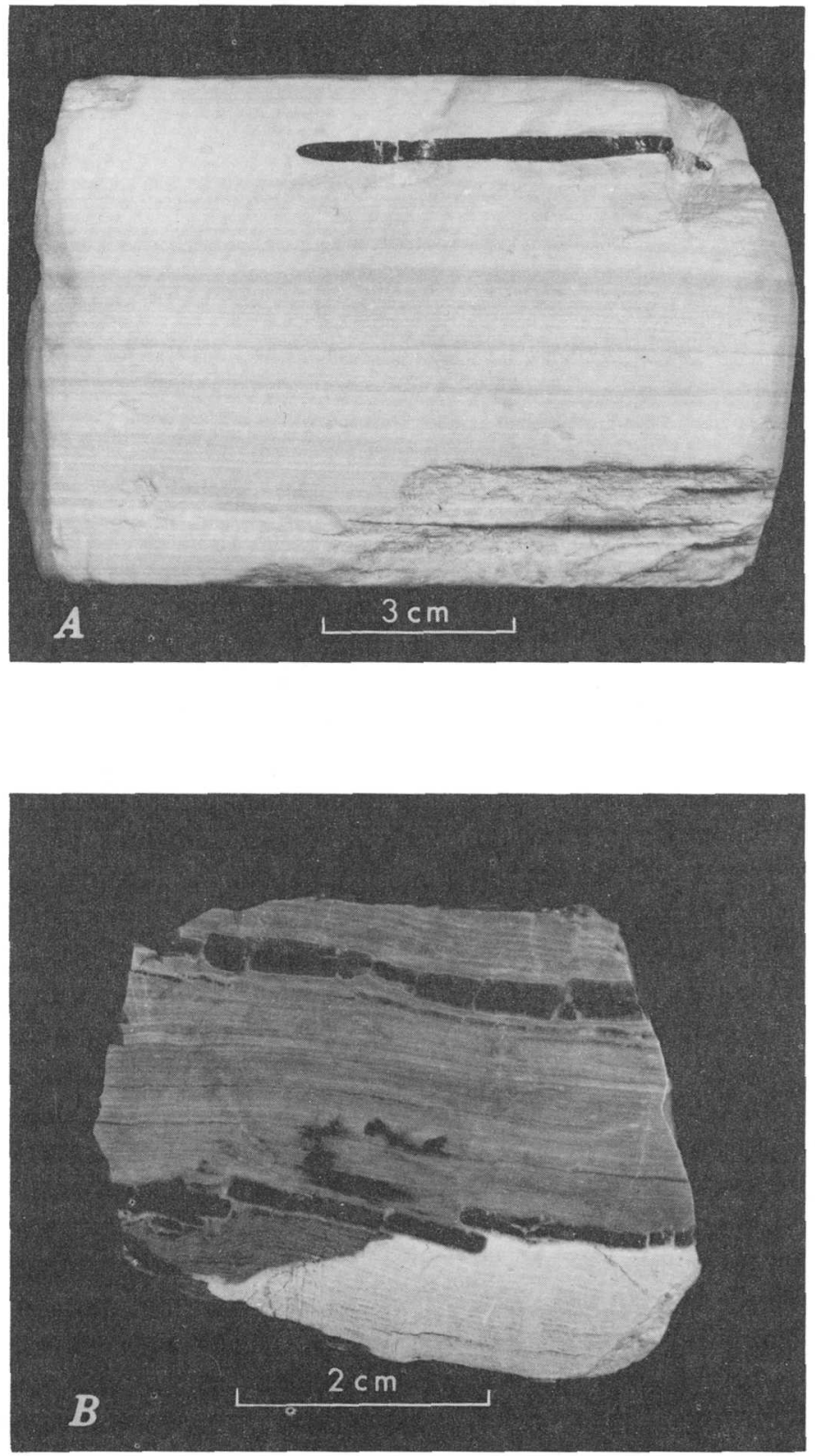

Figure 2.--Early developmental stages of cristobalitic chert in diatomite. A, Section perpendicular to the bedding of commercially mined diatomite, showing a black tabular body of first-formed chert within a thin layer of unusually pure diatomite. $B$, Similar section of an extensive bed of chert from deeper in the mine, showing development of additional chert (gray) around earlier chert (black) through alteration and impregnation of somewhat less pure diatomite represented by the white material at the bottom of the specimen.

\section{SILICA DIAGENSIS IN THE TEMBLOR RANGE- SOURCES AND GENERAL MINERALOGY OF SAMPLES}

The distribution and silica mineralogy of the samples from Chico Martinez Creek and the Taft area in the Temblor Range are shown in figures 3 and 4. At both localities, the regional dip of the beds is to the north- 
TABLE 1.-Analyses of diatomite and of associated layered chert from the lower Sisquoc Formation, and a computed com. position of the chert

[Analysts : B. P. Fabbi and M. J. Cremer]

\begin{tabular}{|c|c|c|c|}
\hline & 1 & 2 & 3 \\
\hline $\mathrm{SiO}_{2}$ & 85.11 & 89.57 & 89.64 \\
\hline $\mathrm{Al}_{2} \mathrm{O}_{3}$ & 2.33 & .84 & .86 \\
\hline $\mathrm{Fe}_{2} \mathrm{O}_{3}$ (total $\left.\mathrm{Fe}\right)$ & .46 & .17 & .17 \\
\hline MgO & .30 & $<.06$ & .11 \\
\hline $\mathrm{CaO}$ & .01 & .00 & .004 \\
\hline $\mathrm{Na}_{2} \mathrm{O}$ & .68 & .26 & .25 \\
\hline $\mathrm{K}_{2} \mathrm{O}$ & .41 & .16 & .15 \\
\hline $\mathrm{H}_{2} \mathrm{O}$ (total) & 10.30 & 8.70 & 8.73 \\
\hline $\mathrm{TiO}_{2}$ & .13 & .06 & .05 \\
\hline $\mathrm{P}_{2} \mathrm{O}_{5}$ & .05 & .06 & .02 \\
\hline MnO & .007 & .004 & .003 \\
\hline $\mathrm{CO}_{2}$ & $<.05$ & $<.05$ & ---- \\
\hline Sum & 99.79 & 99.82 & 100.00 \\
\hline
\end{tabular}

1. Diatomite from an operating mine at Lompoc, Calif.

2. Layered chert (fig. $2 B$ ) in the above diatomite.

. Composition of layered chert computed on the basis of adding 1.70 parts of hydrated silica to 1.00 part of above diatomite. The hydrated silica that yields best fit of the data has the

east, so beds to the southwest are progressively older and once were more deeply buried. The change of silica mineralogy down section, at both places where the regular sequence of biogenic opal to cristobalite to quartz is found, suggests that temperature (and pressure) as a function of depth of burial exerted the major control over rates of phase transformations. Other factors, such as variation in composition of interstitial waters, had negligible effect.

The mineralogy, the $d(101)$ spacing of cristobalite, and dry density of samples from the two localities (table 2) are closely comparable. Much of the following discussion is based on data from Chico Martinez Creek because the sedimentary section there was sampled more closely and because the thickness, petrography, and other features of the formations that make up that section are known in greater detail (Woodring and others, 1940; Elliott and others, 1968; Dibblee, 1973). The top of the youngest marine unit of the region, the Etchegoin Formation that overlies Monterey Shale, was used as datum to estimate the subbottom depth of the sampled rocks when the whole sedimentary pile lay at the bottom of the sea.

The mineralogy of these fine-grained samples is most easily discussed in terms of whole-rock X-ray diffraction patterns. A representative set of patterns of diatomaceous shales and of derivative cherts and porcelanites from the two Temblor Range localities is shown in figure 5, arranged in stratigraphic order. From top downward, the patterns show the conversion of amorphous silica of diatoms $(A, B)$ into cristobalite with increasingly ordered structure $(C-G)$ and ultimately into quartz $(H-J)$. Indications of ordering in the internal structure of cristobalite previously noted by Floerke (1955), Eitel (1958), and Jones and Segnit
(1971), such as the disappearance of the $4.08 \mathrm{~A}$ peak of tridymite, the appearance of weak peaks of cristobalite at $3.14 \mathrm{~A}$ and $2.84 \mathrm{~A}$, and the decrease in $d(101)$ spacing of cristobalite, are all clearly shown in pattern $C-G$.

Sets of diffraction patterns similar to figure 5 were published by Jones, Sanders, and Segnit (1964), who studied precious and ordinary opals from worldwide localities, and by Mizutani (1970), who carried out hydrothermal experiments to convert silica gel into quartz. Figure 5, however, seems to be the first example of details of silica transformations obtained from vertical sections of a single well-exposed formation.

Detrital quartz, usually amounting to less than 2 weight percent, is ubiquitous (patterns $A-E$, fig. 5) and should be ignored. The concentration of quartz indicated by the main peak at $3.342 \mathrm{~A}$ in patterns $E, F$. and $G$ was determined to be $1.5,5.0$, and 18 weight percent, respectively, by comparison with diffraction patterns of standard mixtures of quartz and a cristobalitic chert blank of exceptional purity. No quartz appears to have been produced diagenetically before the stage represented by pattern $F$ in figure 5 .

\section{GEOTHERMAL GRADIENTS IN SUBMARINE DIATOMACEOUS SEDIMENTS}

The transitions from biogenic opal to cristobalite and from ordered cristobalite to quartz occurred in the formations of the Chico Martinez-Zemorra Creek section at estimated depths of 730 and 2,030 m below the top of the Etchegoin, the youngest marine formation of the area (table 2). The temperatures at which these transitions took place can be deduced if the original geothermal gradient within the undisturbed sedimentary pile can be established. The average gradient in these formations in nearby oil fields is $35^{\circ} \pm 3^{\circ} \mathrm{C} / \mathrm{km}$ (locs. 5 and 6 , table 3 ). For normal heat

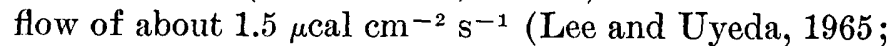
Langseth and von Herzen, 1971), the gradient to be deduced presumably lies between $35^{\circ} \mathrm{C} / \mathrm{km}$ and higher gradients of less consolidated, wetter diatomaceous sediments still underlying the sea floor. Gradients of $40^{\circ} \mathrm{C} / \mathrm{km}$ have been measured in several North Sea basins that are filled with Tertiary and Quaternary clay shales (Evans and Coleman, 1974), but diatomaceous shales would probably have somewhat higher gradients because of their generally lower heat conductivity relative to clay shales (Erickson, 1973).

Data on thermal properties of submarine diatomaceous sediments are scarce, and those from two localities (Nos. 1 and 2, table 3) indicate abnormal gradients of $138^{\circ}-250^{\circ} \mathrm{C} / \mathrm{km}$ because of excessive flow of heat. However, the measured conductivity, mostly $<2.1$ 


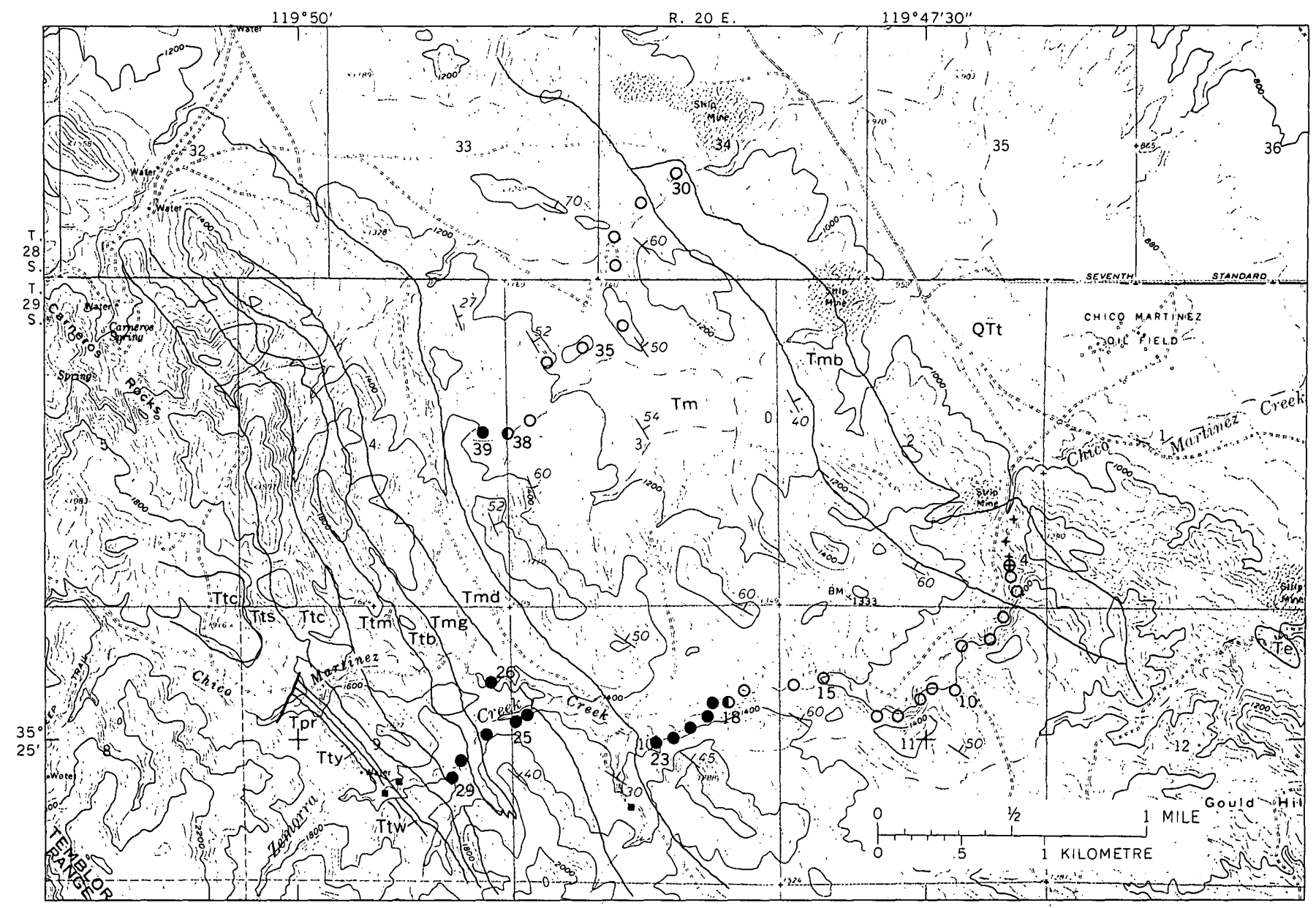

EXPLANATION

TERTIARY AND QUATERNARY

QTt, Tulare Formation TERTIARY

Te, Etchegoin Formation Tmb, Belridge Shale Member Tm, McLure Shale Member Tmd, Devilwater Shale Member

Tmg, Gould Shale Member Ttm, Media Shale Member Ttc, Carneros Sandstone Member Tts, Santos Shale Member Ttw, Wygal Sandstone Member Tty, Cymric Shale Member Tpr, Point of Rocks Sandstone

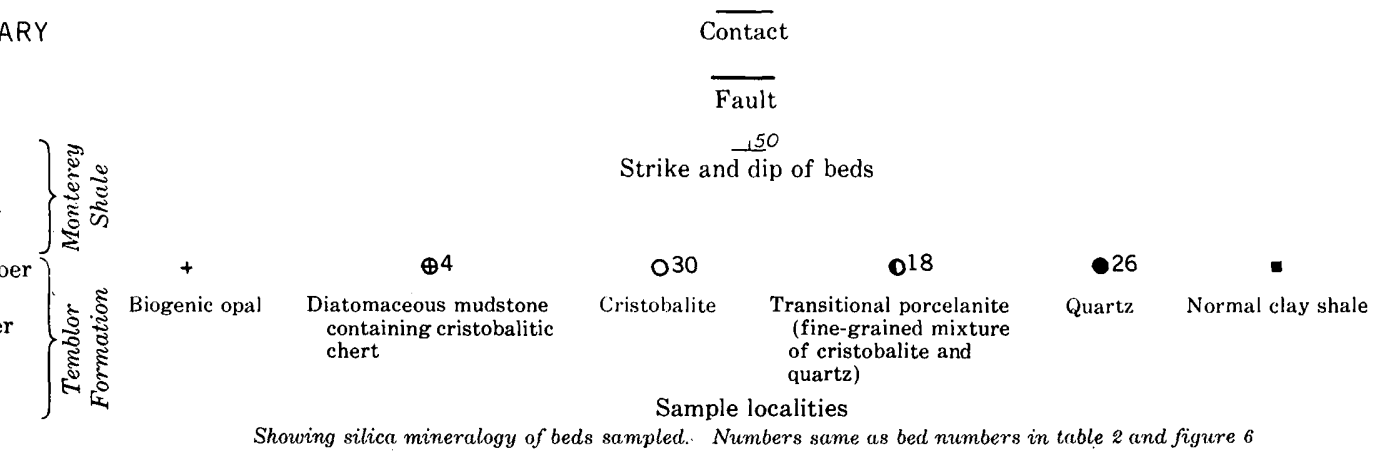

FIgure 3.-Siliceous shale beds sampled along Chico Martinez Creek and environs. Devilwater Shale Member, Buttonbed Sandstone Member, and units below the Media Shale Member are devoid of siliceous shale. Geology from Elliott, Tripp, and Karp (1968) and Dibblee (1973). Base from U.S. Geological Survey 1:24,000 Carneros Rocks, 1959.

mcal $\mathrm{cm}^{-1} \mathrm{~s}^{-1}{ }^{\circ} \mathrm{C}^{-1}$, of the sediments from these localities are typical of wet diatomaceous oozes. It may be noted in passing that despite the high gradient at locality 1, Miocene diatomaceous oozes that lay $170 \mathrm{~m}$ below the seafloor did not contain any cristobalite (Murata and Erd, 1964).

The diatomaceous sediments of the Bering Sea (locs. 3 and 4 , table 3 ) lie in a region with an average

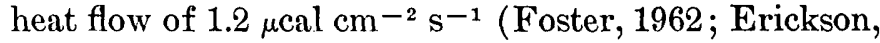
1973), and they have been drilled to a subbottom depth near $700 \mathrm{~m}$ by the Deep Sea Drilling Project (Creager, Scholl, and others, 1973). At subbottom depths of 500$700 \mathrm{~m}$ in the Bering Sea, a widespread seismic reflection horizon, the so-called bottom-simulating reflector, is coincident with an abrupt downward change in lithology from diatomaceous ooze to a harder cristo- 


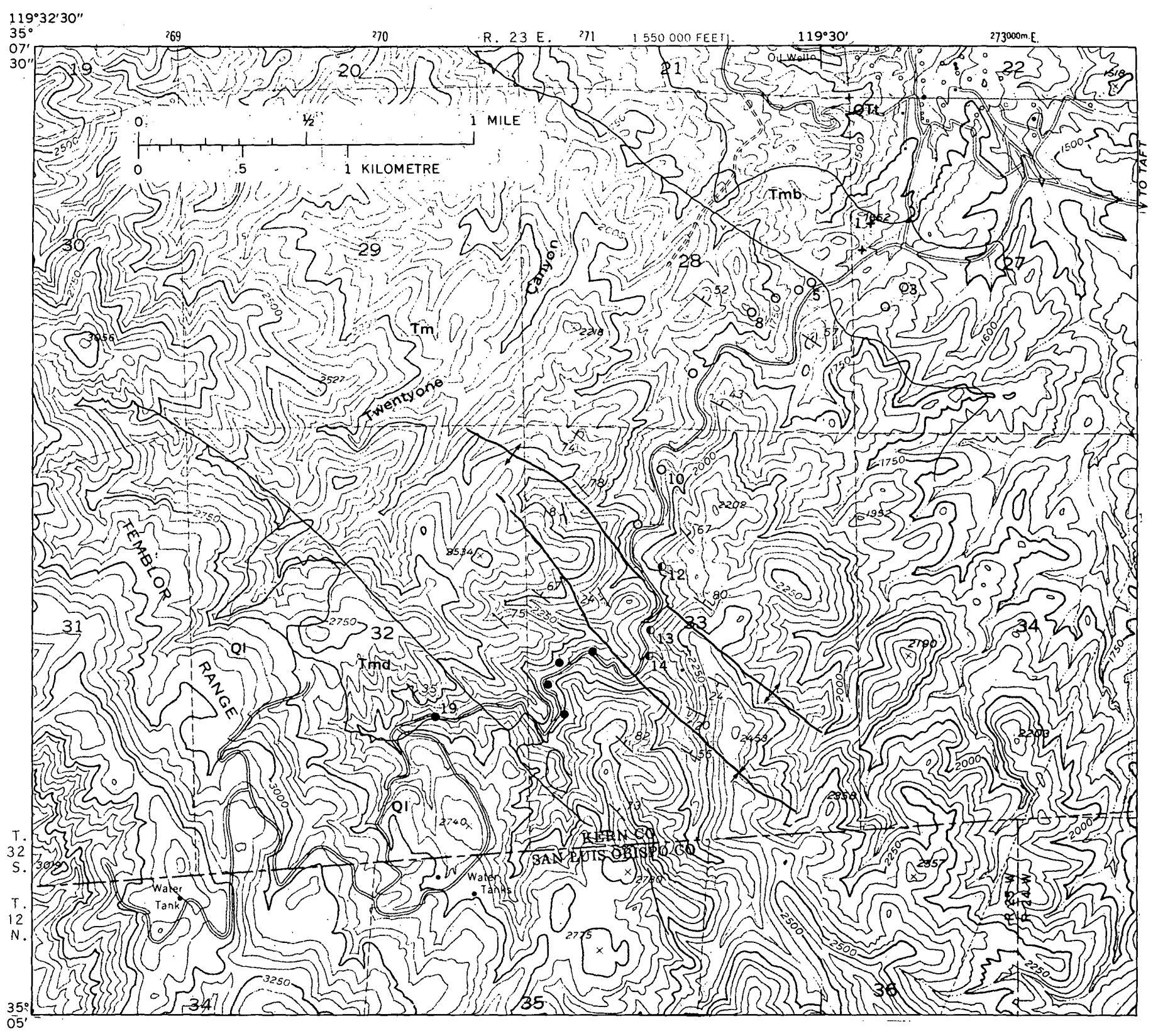

Figure 4.-Locations of samples of siliceous Miocene beds in the Temblor Range southwest of Taft. Symbols indicating the silica mineralogy are the same as those used for figure 3. Geology from Vedder (1970), and sedimentary units are the same as those at Chico Martinez Creek (fig. 3), except that QI depicts Quaternary (Holocene) landslide deposits and that Tmd here probably includes both the Gould and
Devilwater Shale Members of that locality. The interval here occupied by mixed cristobalite-quartz transitional materials seems longer than that at Chico Martinez Creek (fig. 3 ) because of repetition of beds in folds. Base from U.S. Geological Survey 1:24,000 Elkhorn Hills, 1954; Maricopa, 1951. balitic clay and claystone (Scholl and Creager, 1973). Noting that the reflection horizon apparently transgresses the bedding at several sites, these authors concluded that the horizon represents "some sort of a migratory diagenetic boundary related to the dissolution of diatoms and the formation of claystone." The reflection horizon thus corresponds closely to the shale- porcelanite transition at a depth of $730 \mathrm{~m}$ in the Chico Martinez section.

At DSDP site 185 in the Bering Sea, the product of the thermal gradient $\left(50.4^{\circ} \mathrm{C} / \mathrm{km}\right)$ and the average conductivity, 2.04 mcal $\mathrm{cm}^{-1} \mathrm{~s}^{-1}{ }^{\circ} \mathrm{C}^{-1}$, to $667 \mathrm{~m}$, indicate a heat flow of $1.04 \mu \mathrm{cal} \mathrm{cm} \mathrm{cm}^{-2} \mathrm{~s}^{-1}$ (Erickson, 1973). The bottom-simulating reflector at this site is at about 
TABLE 2.-Physical properties of Miocene siliceous shales, cherts, and porcelanites from three localities in the Temblor Range

[-., not detected or determined; $\mathrm{Sh}_{\mathrm{i}} \mathrm{Ch}$, and $\mathrm{Po}$ denote shale (or mud stone), chert, and porcelanite, respectively; $\mathrm{A}, \mathrm{Cr}$, and $Q$ denote amor-

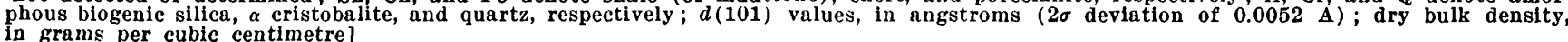

A. Section of Monterey Shale southwest of Taft (fig. 4)

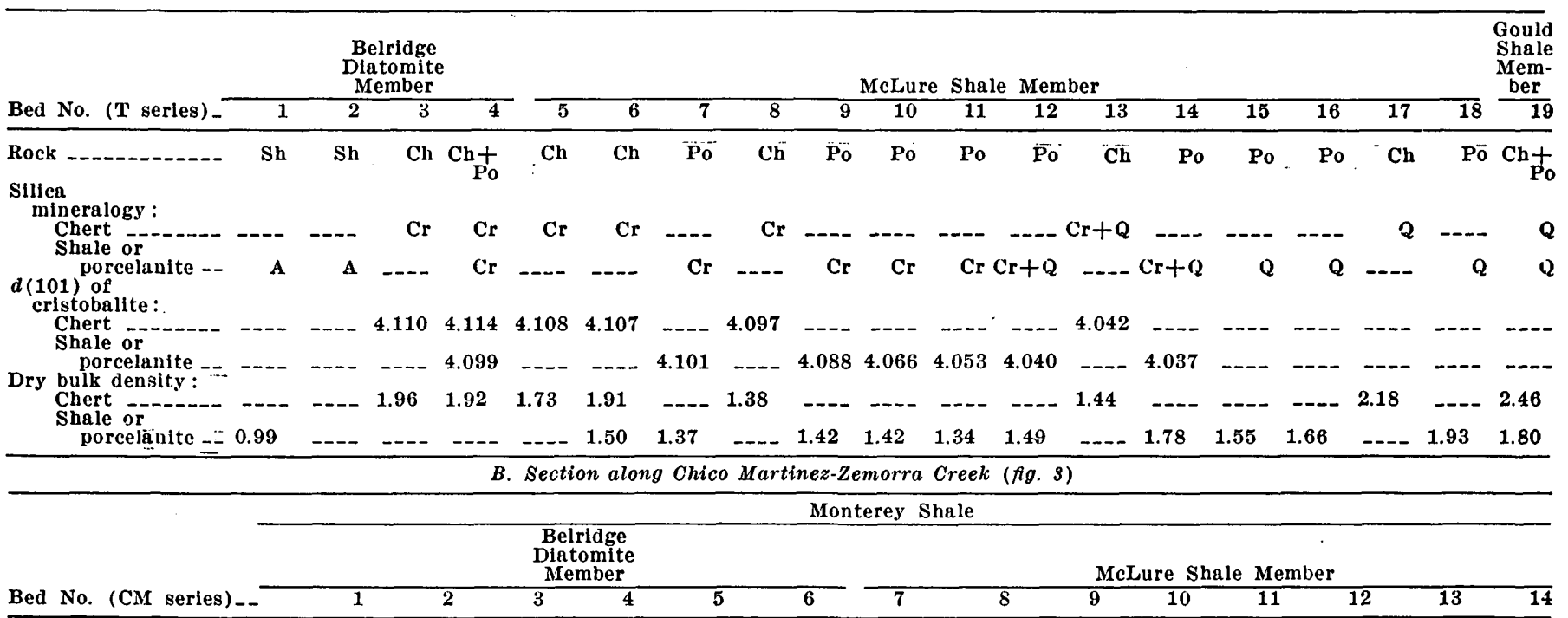

\begin{tabular}{|c|c|c|c|c|c|c|c|c|c|c|c|c|c|c|}
\hline \multicolumn{14}{|l|}{$\begin{array}{l}\text { Stratigraphic posi- } \\
\text { tion, metres below } \\
\text { top of Etcheroin }\end{array}$} & $\begin{array}{r}1,567 \\
\text { Po }\end{array}$ \\
\hline $\begin{array}{l}\text { Silica mineralogy : } \\
\text { Chert }\end{array}$ & --- & ---- & --- & $\mathrm{Cr}$ & $\mathrm{Cr}$ & $\mathrm{Cr}$ & $\mathrm{Cr}$ & $\mathrm{Cr}$ & $\mathrm{Cr}$ & --- & $\mathrm{Cr}$ & $\mathrm{Cr}$ & --- & --- \\
\hline $\begin{array}{c}\text { Snale or } \\
\text { porcelanite }=-\end{array}$ & $\boldsymbol{A}$ & $\mathbf{A}$ & A & A & Cr & $\mathbf{C r}$ & ---- & $\mathrm{Cr}$ & $\mathrm{Cr}$ & $\mathrm{Cr}$ & $\mathrm{Cr}$ & $\mathrm{Cr}$ & $\mathrm{Cr}$ & $\mathrm{Cr}$ \\
\hline Chert - & --- & --- & ---- & 4.116 & 4.117 & 4.106 & 4.103 & 4.097 & 4.098 & --- & 4.094 & 4.092 & -... & $-\ldots$ \\
\hline $\begin{array}{c}\text { Snale or } \\
\text { porcelanite } \\
\text { Dry bulk density: }\end{array}$ & --- & ---- & --- & --- & 4.106 & 4.093 & 4.089 & 4.089 & 4.090 & 4.087 & 4.087 & 4.084 & 4.079 & 4.077 \\
\hline $\begin{array}{l}\text { Chert } \\
\text { Shale or }\end{array}$ & $-\ldots$ & --- & ---- & 1.78 & 1.82 & 1.68 & 1.45 & 1.41 & 1.83 & --- & 1.32 & 1.55 &.-- & --- \\
\hline porcelanite. =- & 1.14 & 1.04 & .94 & .86 & 1.06 & 1.32 & 1.11 & 1.31 & 1.06 & 1.13 & 1.22 & 1.22 & 1.15 & 1.13 \\
\hline \multicolumn{13}{|c|}{ Monterey Shale } & \multirow{2}{*}{\multicolumn{2}{|c|}{$\begin{array}{c}\text { Temblor } \\
\text { Formation : } \\
\text { Media } \\
\text { Shale } \\
\text { Member } \\
\end{array}$}} \\
\hline & & & & & & ember & & & & Goul & d shale & Tember & & \\
\hline Bed No. (CM series) -- & $\overline{15}$ & 16 & $\overline{17}$ & 18 & $\overline{19}$ & 20 & 21 & 22 & 23 & 24 & 25 & & $\overline{28}$ & 29 \\
\hline
\end{tabular}

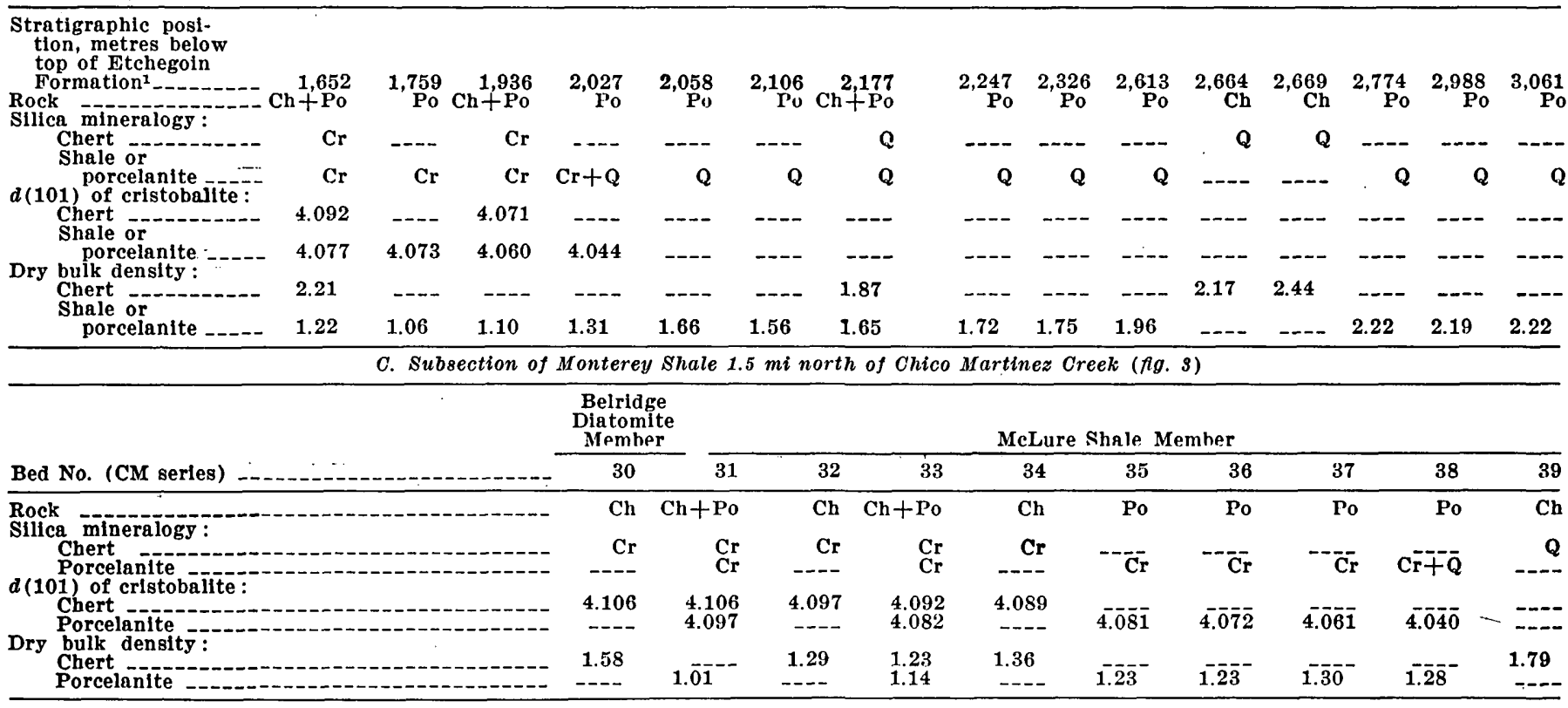

I The thickness of the uppermost $570 \mathrm{~m}(380 \mathrm{~m}$ of Etchegoln Formation and $190 \mathrm{~m}$ of Belridge Diatomite Member) of the section was estiThe thickness of the uppermost $570 \mathrm{~m}(380 \mathrm{~m}$ of Etchegoln Formation and $190 \mathrm{~m}$ of Belridge Dlatomite Member) of the section was e
mated from subsurface data of nearby oil fields (Elliott and others, 1968); the remaining thicknesses are measured values (Dibblee, 1973 ). 


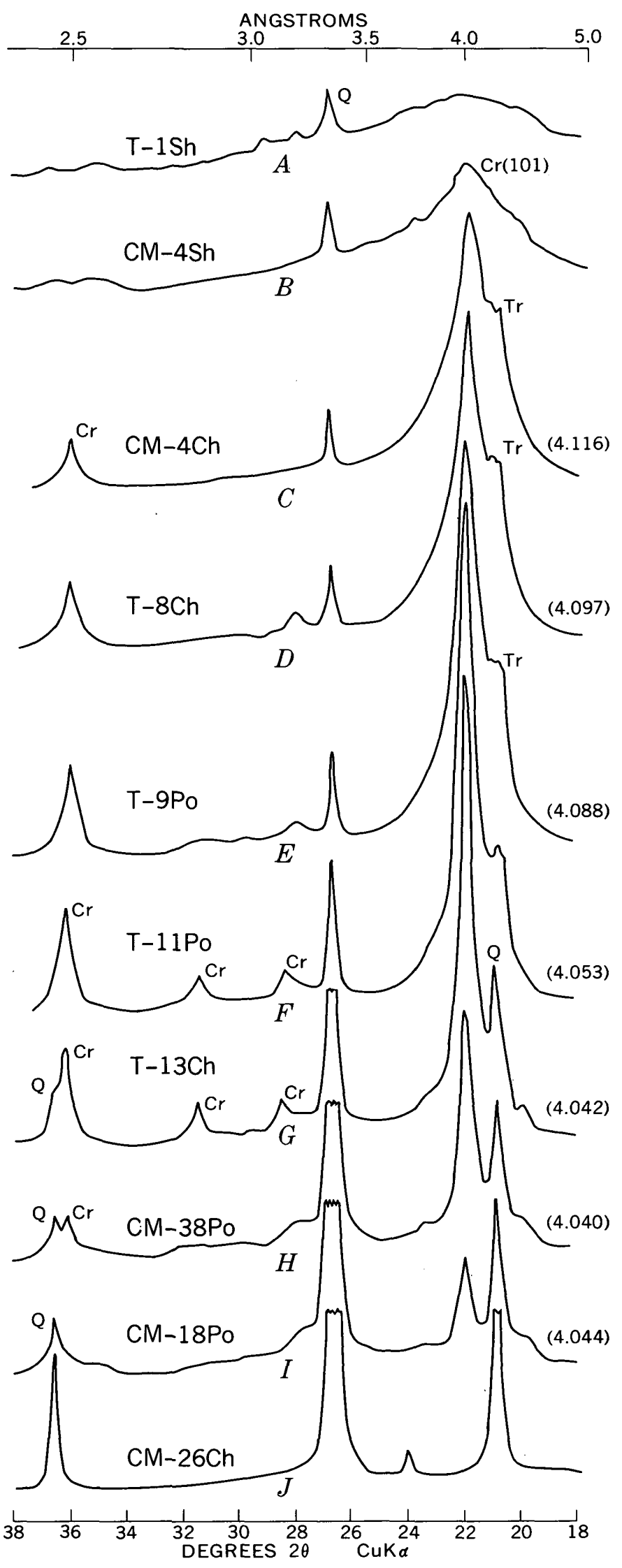

$670 \mathrm{~m}$ (Scholl and Creager, 1973); at and just below this depth Erickson (1973) found the average conductivity in diatom-bearing silty clay to be 2.82 mcal $\mathrm{cm}^{-1} \mathrm{~s}^{-1}{ }^{\circ} \mathrm{C}^{-1}$. Disturbance of some of the deeper silty clays by effervescing gases made Erickson somewhat doubtful of the significance of the higher conductivities he obtained for the clay below $670 \mathrm{~m}$. But the descriptions and photographs of many of these deep samples, notably those from cores 185-20-6, 185-21-1, 185-21-2, and 185-23-2, indicate firm, little disturbed sediments (Creager, Scholl, and others, 1973, p. 169185). We therefore infer that the higher conductivity of $2.82 \mathrm{mcal} \mathrm{cm} \mathrm{cm}^{-1} \mathrm{~s}^{-1}{ }^{\circ} \mathrm{C}^{-1}$ is a good average value for the diagenetically altered clay that very likely corresponds to porcelanite of Chico Martinez Creek.

These sparse data from site $\mathbf{1 8 5}$ in the Bering Sea are the best available for reconstructing a provisional depth-temperature curve for the Chico Martinez siliceous sediments before their uplift above sea level. On the basis of the present heat flow of $1.29 \mu \mathrm{cal} \mathrm{cm}^{-2}$ $\mathrm{s}^{-1}$ in the area of Chico Martinez Creek (table 3) and the in situ conductivity of Bering Sea deposits, the gradient of the Chico Martinez section would have been $63^{\circ} \mathrm{C} / \mathrm{km}$ to a subbottom depth of $730 \mathrm{~m}, 46^{\circ} \mathrm{C} / \mathrm{km}$ between 730 and $2,030 \mathrm{~m}$, and probably lower in the more conductive quartzose diagenetic zone below. The resultant depth-temperature curve (fig. 6F) suggests that the in situ temperature of the biogenic opalcristobalite transition at $730 \mathrm{~m}$ in the submarine section would have been $50^{\circ} \mathrm{C}$ (assuming a sea-bottom temperature of $4^{\circ} \mathrm{C}$ ) and of the cristobalite-quartz transition at $2,030 \mathrm{~m}, 110^{\circ} \mathrm{C}$.

Oxygen isotope compositions indicate a temperature of $50^{\circ} \mathrm{C}$ for the first-formed cristobalitic chert and $80^{\circ} \mathrm{C}$ for the first-formed quartoze chert, under the assumption that the water in equilibrium with the silica minerals was Standard Marine Ocean Water (Irving Friedman and J. D. Gleason, written commun., August 1974). These temperatures yield a gradient of only $23^{\circ} \mathrm{C} / \mathrm{km}$, which even if the heat flow were as low

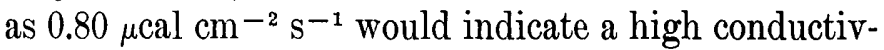
ity of $3.5 \mathrm{mcal} \mathrm{cm}{ }^{-1} \mathrm{~s}^{-1}{ }^{\circ} \mathrm{C}^{-1}$ for sediments of the

Figure 5.-Typical X-ray diffractometer patterns of diatomaceous shales and derivative cherts and porcelanites from the Temblor Range, arranged in stratigraphic order of the samples. Samples with prefix CM are from Chico Martinez Creek; those with prefix $T$, from southwest of Taft; the numbers are the same as those used in table 2. Symbols in the sample designation are Sh, shale; $\mathrm{Ch}$, chert; and Po, porcelanite. $\mathrm{Cr}, \mathrm{Q}$, and $\mathrm{Tr}$ identify diffraction peaks of cristobalite, quartz, and tridymite, respectively. Number in parentheses is overall $d(101)$ spacing, in angstroms, of cristobalite of the rock as a whole. 
TABLE 3.-Measured thermal conductivities and gradients and some computed gradients in diatomaceous sediments and rocks

\begin{tabular}{|c|c|c|c|c|c|c|c|}
\hline & Locality & $\begin{array}{l}\text { Age of } \\
\text { deposit }\end{array}$ & $\begin{array}{c}\text { Depth } \\
\text { interval } \\
\text { or maxi- } \\
\text { mum } \\
\text { depth } \\
\text { (metres) } \\
\end{array}$ & $\begin{array}{c}\text { Conductivity } \\
\left(\begin{array}{c}\text { meal } \mathrm{cm}^{-1} \\
\left.\mathrm{~s}^{-1}{ }^{\circ} \mathrm{C}^{-1}\right)\end{array}\right.\end{array}$ & $\begin{array}{l}\text { Average } \\
\text { gradient } \\
\text { o } \mathbf{C} / \mathrm{km}) \\
\end{array}$ & $\begin{array}{l}\text { Average } \\
\text { heat } \\
\text { flow } \\
(\mu \mathrm{cal} \\
\left.\mathrm{cm}^{-2} \mathrm{~s}^{-1}\right) \\
\end{array}$ & Reference \\
\hline \multicolumn{8}{|c|}{ Pacific Ocean } \\
\hline 1. & $\begin{array}{l}\text { Experimental } \\
\text { Mohole near } \\
\text { Guadalupe } \\
\text { Island, Mexico. }\end{array}$ & $\begin{array}{l}\text { Quaternary } \\
\text { to Miocene. }\end{array}$ & 170 & $1.82-2.27$ & 138 & 2.81 & $\begin{array}{l}\text { Von Herzen and } \\
\text { Maxwell, } 1964 .\end{array}$ \\
\hline & $\begin{array}{l}\text { Gulf of } \\
\text { California. }\end{array}$ & Quaternary -..--- & 5 & $1.62-1.75$ & 250 & 3.8 & $\begin{array}{c}\text { Lawver, Sclater, } \\
\text { Henyey, and } \\
\text { Rogers, } 1973 .\end{array}$ \\
\hline & $\begin{array}{l}\text { Bering Sea } \\
\text { sites 11-14b. }\end{array}$ & - - do _ & 2 & $1.5-1.7$ & 65 & 1.1 & Foster, 1962 \\
\hline & $\begin{array}{l}\text { Bering Sea } \\
\text { sites } 184-191 .\end{array}$ & $\begin{array}{l}\text { Pleistocene } \\
\text { to Miocene. }\end{array}$ & 700 & $1.88-3.03$ & 66 & 1.4 & Erickson, 1973. \\
\hline \multirow[t]{2}{*}{ 4a. } & $\begin{array}{l}\text { Bering Sea } \\
\text { site } 185\end{array}$ & ---_do - - - - & $2-667$ & 2.04 & $(63.2)^{2}$ & 1.04 & $\begin{array}{l}\text { Erickson, } 1973, \\
\text { table } 9\end{array}$ \\
\hline & & Miocene --- & $670-685$ & 2.82 & $(36.4))^{3}(45.7)^{2}$ & 1.04 & Do. \\
\hline \multicolumn{8}{|c|}{ California oil fields near Chico Martinez Creek } \\
\hline \multirow{4}{*}{\multicolumn{2}{|c|}{$\begin{array}{l}\text { 5. Western Kern } \\
\text { County fields. } \\
\text { 6. Berry well } \\
\text { 1, north } \\
\text { Belridge field. }\end{array}$}} & $\begin{array}{l}\text { Quaternary } \\
\text { and Tertiary. }\end{array}$ & 3,000 & $\ldots-\cdots$ & $35 \pm 3$ & --- & Moses, 1962. \\
\hline & & - - do - do - - & 2,700 & $2.78-5.61$ & 34.6 & 1.29 & Benfield, 1947. \\
\hline & & $\begin{array}{l}\text { Pliocene and } \\
\text { Miocene. }\end{array}$ & $190-1,610$ & 3.55 & $(36.3)^{2}$ & 1.29 & Do. \\
\hline & & Mincene & $1,610-2,700$ & 4.20 & $(30.7)^{2}$ & 1.29 & Do. \\
\hline
\end{tabular}

cristobalitic zone. Temperatures computed above on the basis of measured thermal conductivities of the Bering Sea sediments will suffice for the present study. Future selection of different value of transition temperatures will not invalidate the following discussion on transition mechanisms, which is based on relative rather than absolute solubilities of the silica phases.

\section{Transition: biogenic opal-cristobalite}

Diatomaceous rocks are restricted to the uppermost member (Belridge Diatomite Member) of the Monterey Shale throughout the Temblor Range. They are not as pure as the commercial diatomite of Lompoc (fig. $2 A$ ), and their bulk density of $0.86-1.14 \mathrm{~g} / \mathrm{cm}^{3}$ (samples $1-4$, fig. $6 E$ ) varies directly with the amount of terrigenous contaminants.

As with the previously discussed diatomites of Lompoc, conversion of diatomaceous rocks of the Temblor Range into cristobalitic cherts and porcelanites involved dissolution of the siliceous remains, limited migration of the dissolved silica, and precipitation of cryptocrystalline cristobalite. At Chico Martinez Creek, only about $20 \mathrm{~m}$ of transitional beds separates the base of the zone of diatomaceous mudstone from the top of diatom-free porcelanite. The abrupt transition suggests that, once the proper pressure-temperature conditions were attained, the conversion proceeded quickly.
The transformation of biogenic opal of siliceous shales to metastable cristobalite rather than to stable quartz can be explained in terms of the silica-rich solution (for example, up to $180 \mathrm{ppm} \mathrm{SiO}_{2}$ at $50^{\circ} \mathrm{C}$ ) that forms when amorphous biogenic opal dissolves in water with $\mathrm{pH}$ of about 7 . The solubility of chalcedony (Fournier, 1973) rather than that of macroscopic quartz is used in the following discussion because diagenetic quartz of Monterey Shale is an extremely fine grained microquartz, whose solubility is probably closer to that of chalcedony than to that of macroquartz. The silica solution that is saturated with respect to biogenic opal at $50^{\circ} \mathrm{C}$ is about 5 times supersaturated. with respect to chalcedony but only 1.4 times supersaturated with respect to disordered cristobalite (Fournier, 1973, his $\beta$ cristobalite ${ }^{1}$ ). Chalcedony (diagenetic microquartz) does not grow from such a solution probably because the deposition of silica units onto the crystal surface is too fast and the orderly rearrangement of the deposited units, too slow for continued growth. On the other hand, disordered cristobalite forms from the same solution because the kinetics of deposition and rearrangement of silica units on this more soluble and irregularly structured mineral are appropriate for its steady growth (White and others, 1956; Jones and Segnit, 1972).

${ }^{1}$ An X-ray examination of a sample of this material kindly suppiled by $\mathrm{R}$. O. Fournier showed it to be disordered a cristobalite with
$d(101)$ of $4.108 \mathrm{~A}$. 

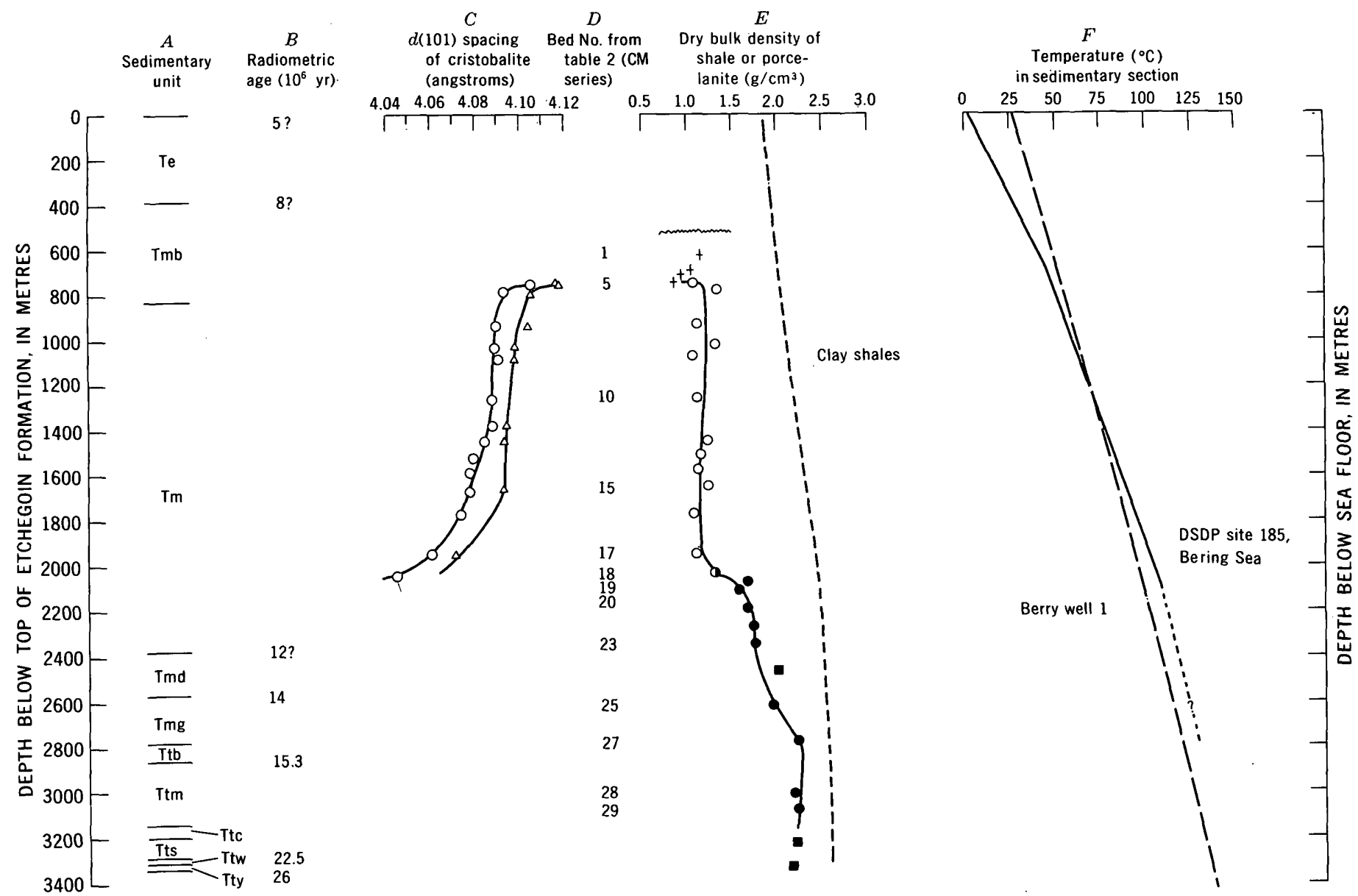

Figure 6.-Physical properties of the siliceous rocks along Chico Martinez-Zemorra Creek and subsurface temperature of a nearby oil well plotted against stratigraphic position below the top of Etchegoin Formation, and depth-related properties of comparison rocks from other localities. $A$, Names and ages of sedimentary units as given in figure 3. $B$, Radiometric ages of California Miocene and Pliocene strata as published by Evernden, Savage, Curtis, and James (1964), Bandy and Ingle (1970), Turner (1970), and J. D. Obradovich in Huffman (1972). $C$, Circles denote $d$-spacing in cristobalitic porcelanites; triangles, $d$-spacing in cristobalitic cherts (Murata and Nakata, 1974). D, Bed number in

\section{Depth-related changes in cristobalite}

As previously noted in figure 5, the progressive ordering of the structure of cristobalite is best seen in the increasing sharpness of X-ray reflections and in the decreasing $d(101)$ spacing in samples from successively deeper levels. Cristobalite porcelanite and chert have separate curves relating their $d(101)$ spacing to depth of burial (fig. $6 \mathrm{C}$ ). At any given depth, the spacing of porcelanite is $0.004-.015 \mathrm{~A}$ smaller than that of associated chert, probably because porcelanite formed later (at a higher temperature) in the thickening pile of sediments.

The bulk refractive index increases from about 1.448

CM series from Table 2. $E$, Crosses denote diatomaceous shale; open circles, cristobalitic porcelanite; half-filled circles, transitional porcelanite with both cristobalite and quartz; filled circles, quartzose porcelanite; and filled squares, normal clay shales; data from table 2; dashed line indicates densities of normal clay shales from Athy (1930) and Hedberg (1936). $F$, Data for Berry well 1 are from Benfield (1947); the top $210 \mathrm{~m}$ of nonmarine Pleistocene and Holocene deposits have been excluded; data for DSDP site 185 under the Bering sea are from table 3 and from Erickson (1973); depths are metres below the sea floor.

among poorly ordered cristobalites to about 1.478 among those well ordered. This rise in index suggests that the ordering process entails a systematic expulsion of water from the porous cristobalite aggregates and a simultaneous contraction of their volume (Taliaferro, 1935).

The bulk density of the cristobalitic rocks might be expected to throw light on the overall nature of the ordering process. The density of cristobalitic chert (table 3) is highly variable $\left(1.23-2.21 \mathrm{~g} / \mathrm{cm}^{3}\right)$ and fluctuates randomly with depth of burial, so it is not considered further. The density of cristobalitic porcelanite, a far more abundant rock, is relatively constant, 
averaging 1.16 with a range of $1.06-1.32 \mathrm{~g} / \mathrm{cm}^{3}$, throughout the 1,300-m thickness of the cristobalitic zone at Chico Martinez Creek (fig. $6 E$ ). The low values are in keeping with the highly porous nature of porcelanites (Beal and Fischer, 1969, p. 584), and the lack of any systematic variation of bulk density suggests that the depth-dependent ordering of the constituent cristobalite was mostly an internal solid-state adjustment that did not substantially change the amount of silica in a unit volume of the rock.

Fournier (1973) showed that ordered cristobalite is less soluble than disordered cristobalite by roughly $100 \mathrm{ppm}$ in the temperature range of $50-110^{\circ} \mathrm{C}$. All structurally constant phases of silica increase in solubility as the temperature rises, up to about $300^{\circ} \mathrm{C}$. But cristobalites of a cristobalitic diagenetic zone would show very little increase in solubility as the temperature rises because of the contrary trend toward lower solubility as the structural order increases. According to Fournier's data (1973), solubility of disordered cristobalite would be $130 \mathrm{ppm}$ for the $50^{\circ} \mathrm{C}$ temperature at the top of the diagenetic zone and solubility of ordered cristobalite would be $150 \mathrm{ppm}$ for the $110^{\circ} \mathrm{C}$ temperature at the bottom of the zone. Such a small range in the equilibrium concentration of silica throughout the entire zone would explain the limited variation in the density of cristobalitic porcelanite and support the idea that the ordering of cristobalite is largely a solid-state process.

Siliceous shales are often difficult to subdivide for a detailed study because they seldom have extensive marker beds. At Chico Martinez Creek, about 1,200 m of cristobalitic porcelanites had to be included in a single unit, the McLure Shale Member of the Monterey Shale (Dibblee, 1973). Studies underway indicate that the $d(101)$ spacing of cristobalite offers a means of dividing such a thick unit into three to four subunits, and that isopleths based on $d(101)$ values of many widespread samples from a given area can show details of folding and faulting of the beds.

\section{Transition: ordered cristobalite-microquartz}

The transformation of ordered cristobalite into microquartz most likely occurred through a solutionprecipitation process involving water solutions (Ernst and Calvert, 1969). In thin sections of transitional samples, microquartz is seen to have crystallized from many centers in a fine-grained cristobalitic matrix, and its continued growth disrupted the fine sedimentary layering and reduced the porosity of the rock.

Microquartz forms only at the bottom of the cristobalitic diagenetic zone, where cristobalite is well ordered (fig. 5, $F-G$ ). Why some microquartz does not form at higher levels within the cristobalitic zone can be explained in at least two ways: (1) A temperature of $110^{\circ} \mathrm{C}$ or so may be a boundary temperature for both the complete ordering of cristobalite and the precipitation of microquartz; from this view, the association of microquartz with well-ordered cristobalite in transitional samples is merely a coincidence without any genetic significance, or (2) well-ordered cristobalite is a necessary precursor for microquartz. We prefer the second explanation although it requires a mechanism by which the structural state of the cristobalite undergoing dissolution influences the nature of the polymorph that precipitates from the resultant solution.

At $110^{\circ} \mathrm{C}$, the solubility of ordered cristobalite (150 ppm) is only about half that of highly disordered cristobalite $(290 \mathrm{ppm})$, according to Fournier (1973). With respect to chalcedony (microquartz), the solution formed from disordered cristobalite is 3.0 times supersaturated whereas the one from ordered cristobalite is only 1.5 times supersaturated. As previously noted in connection with the conversion of biogenic opal into disordered cristobalite, excessive supersaturation is inimical to the growth of a silica mineral, and we believe that among cristobalites of various degrees of order, only the well-ordered one yields the moderately supersaturated solution that is most appropriate for growth of microquartz.

As shown in beds 17-19 of Chico Martinez Creek (fig. $6 E$ ), the bulk density of porcelanite rises rapidly across the 80-m-thick zone of cristobalite-quartz transition, going from an average value of $1.16 \mathrm{~g} / \mathrm{cm}^{3}$ to about $1.60 \mathrm{~g} / \mathrm{cm}^{3}$, and thence more gradually toward the bottom of the section to $2.22 \mathrm{~g} / \mathrm{cm}^{3}$. The density variations support the solution-precipitation mechanism for the phase transition and indicate that the transition was accompanied by a general reduction in porosity through introduction of silica (Heath and Moberly, 1971). In comparison to normal clay shales (dashed line, fig. $6 E$ ), the porcelanites and the three normal shales from Chico Martinez Creek are consistently less dense.

The conversion of cristobalite into quartz under hydrothermal conditions $\left(100^{\circ}-500^{\circ} \mathrm{C}, 100-2,000\right.$ bars fluid pressure) has been studied experimentally with the use of either pure water or solutions of various alkalies (Campbell and Fyfe, 1960; Ernst and Calvert, 1969; Mizutani, 1970; among others). Reaction rates determined by these studies indicate that at $110^{\circ} \mathrm{C}$ the conversion would have been completed in only 14,000 yr (Ernst and Calvert, 1969) or less. The thinness (about $80 \mathrm{~m}$ ) of the transition interval between the cristobalitic and quartzose diagenetic zones in Chico 


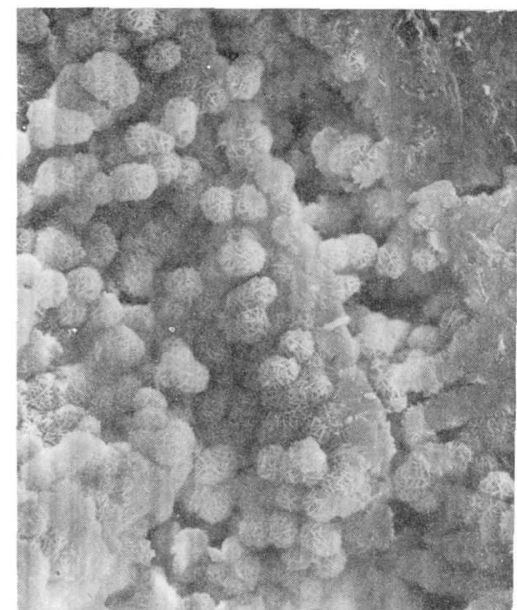

$A$

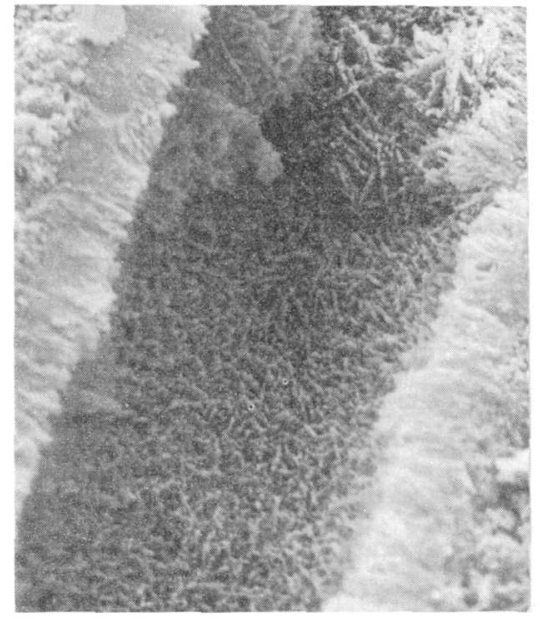

$D$
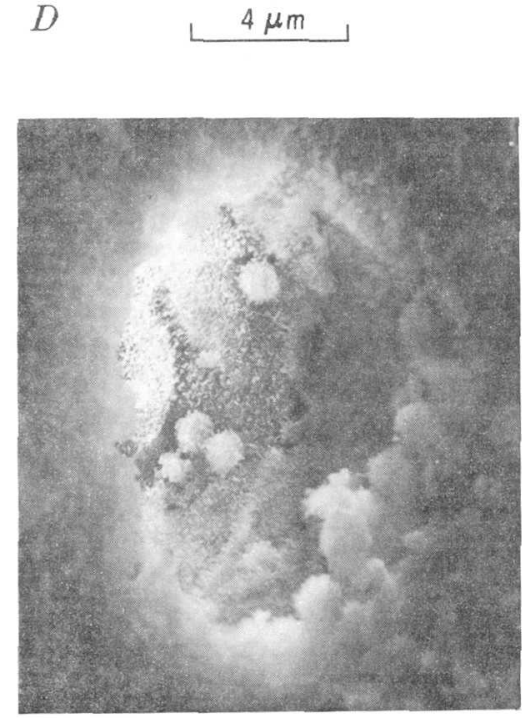

G

$10 \mu \mathrm{m}$

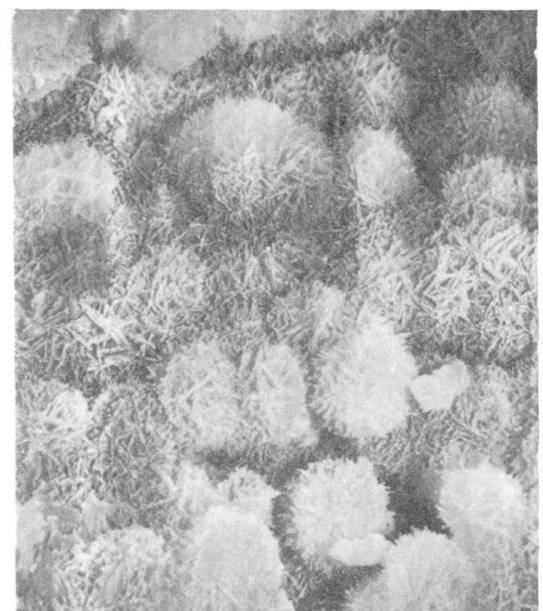

$E$

$10 \mu \mathrm{m}$

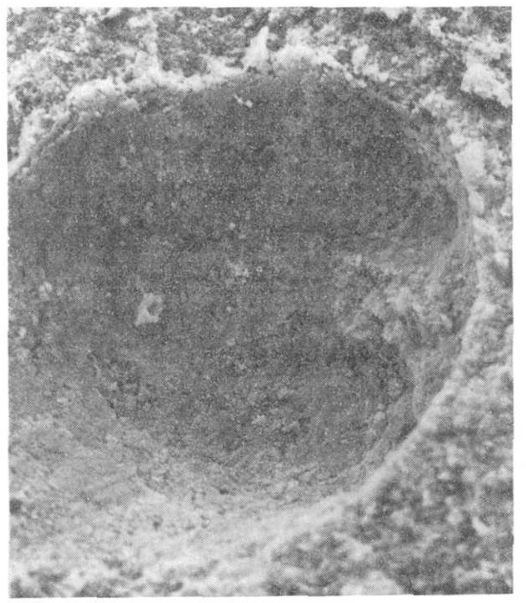

$H$

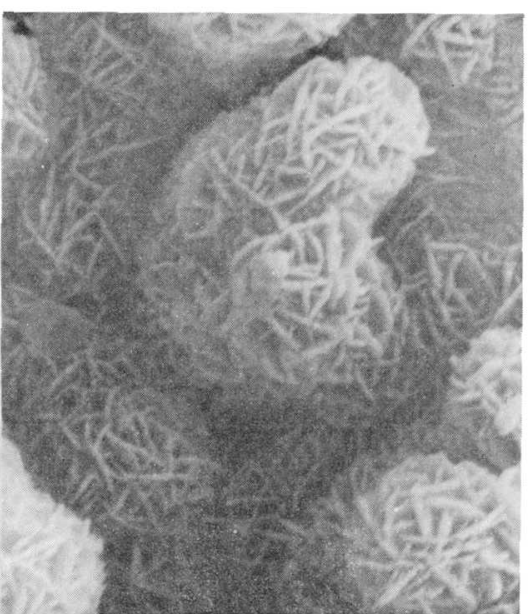

$B$

$2 \mu \mathrm{m}$
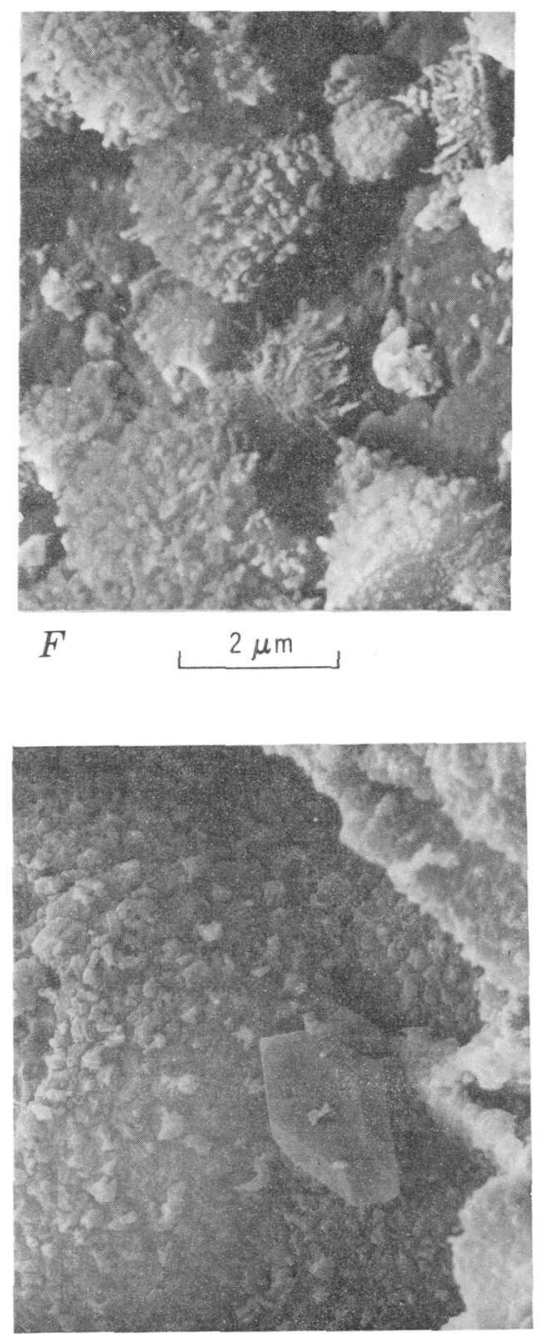

F

$I$

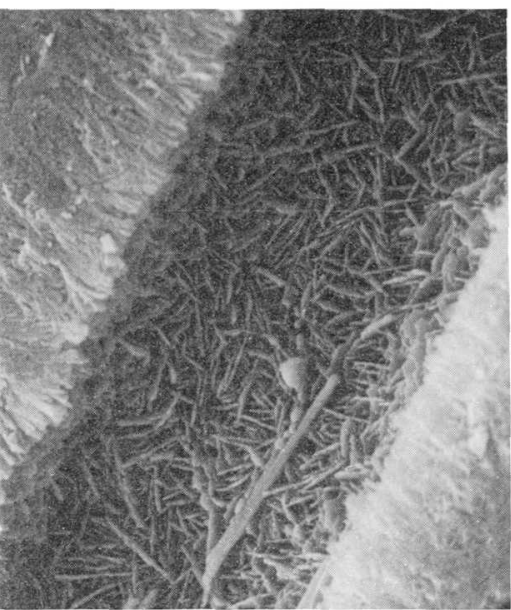

C

$4 \mu \mathrm{m}$

\section{$2 \mu \mathrm{m}$}

$10 \mu \mathrm{m}$
Figure 7.-Scanning electron micrographs of silica minerals in and around cavities in chert and porcelanite. The number in parentheses is overall $d(101)$ spacing, in angstroms, of cristobalite of the rock as a whole. A, Spherical and stubby aggregates of bladed cristobalite in vugs in chert (4.116) of bed CM-4. $B$, Enlargement of part of $A$.
$C$. Feathery aggregates of bladed cristobalite lining the wall of a tubular cavity in chert (4.106) of bed CM-30. D, Aggregates of cristobalite in porcelanite $(4,088)$ of bed $\mathrm{T}-9$; compared to similar aggregates in $C$, the crystals are more irregular and nubby rather than bladed. $E$, Spherical aggregates of bladed crystals of cristoabilte in chert (4.092) 
Martinez section is in qualitative agreement with such a rapid rate of conversion.

The laboratory experiments give no inkling that the state of structural order of cristobalite influences the transformation to quartz. These experiments are usually carried out at $200^{\circ} \mathrm{C}$ or higher because of the generally sluggish reaction of silica at lower temperature. At the higher temperatures, solubilities of the several silica ploymorphs become much alike; for example, at $300^{\circ} \mathrm{C}$ the solubility of amorphous opal is only twice that of quartz (Fournier, 1973); this fact raises the possibility of an almost direct conversion of opal into quartz with perhaps a minor role for intervening cristobalite. Only at lower temperatures do the several polymorphs (including variously ordered cristobalite) manifest substantially different solubilities that lead to the three stages of diagenesis like those seen at Chico Martinez Creek.

\section{SCANNING ELECTRON MICROSCOPIC INVESTIGATIONS}

We have used the scanning electron microscope (SEM) to determine if microcrystals of the kind found in cavities in deep-sea cherts (Pimm and others, 1971; Wise and others, 1972; Berger and von Rad, 1972; Lancelot, 1973) are present in the Monterey Shale and if progressive ordering of the internal structure of diagenetic cristobalite could be correlated with aspects of the external morphology of crystals.

Rocks consisting of poorly ordered cristobalite, with $d(101)$ spacing of $4.10 \mathrm{~A}$ or greater (fig. $7 A, B$, and $C$ ), have well-formed bladed crystals that make up spherical aggregates or feathery linings of cavities, just like those previously reported from deep-sea chert and porcelanite. Rocks with better ordered cristobalite with $d(101)$ less than $4.10 \mathrm{~A}$ (fig. $7 D, E, F$, and $G$ ) have poorly shaped cavity crystals that tend to be spiny rather than bladed. The internal structure of the host cristobalite thus seems to be reflected in the habit of crystals growing in its cavities.

Porcelanite $(4.040)$ of bed CM-38 is a transitional rock that is mostly quartz with minor cristobalite, and most of its cavities are empty (fig. $7 H$ ). In view of

\footnotetext{
Fraure 7.-Continued

of bed CM-15; compared to similar aggregates in $A$ and $B$, the crystals seem more skeletal and spiny. $F$, Spiny aggregates of cristobalite in a cavity in chert (4.071) of bed CM-17. $G$, Nubby to spiny cristobalite as cavity lining and as spherical aggregates in another sample of chert (4.071) of bed CM-17. $H$, Typical empty cavity in transitional porcelanite (4.040) of bed CM-38 whose silica is mostly quartz; such cavities probably contained spiny cristobalite aggregates like those of $G$ which were dissolved away in the cristobalite-quartz transition. I, Crystal of quartz (center) formed inside a cavity of a calcitic microfossil in quartzose chert of bed CM-26.
}

the common occurrence of filled cavities in precedent cristobalitic rocks, cavities in this porcelanite may once have contained microcrystals of cristobalite that were subsequently dissolved during the cristobalite-quartz transformation.

The occurrence of the quartz crystal of figure $7 I$ is in keeping with the quartzose nature of its host chert. The crystal lies within a test of a foraminifer, so the calcareous microenvironment may have promoted its formation. The SEM micrographs were obtained in an exploratory study so only tentative inferences can be drawn from them. The intriguing possibility of correlating the habit of cavity crystals with the structural state of the matrix cristobalite of the host rock invites further SEM studies of Monterey Shale.

\section{REFERENCES CITED}

Athy, L. F., 1930, Density, porosity and compaction of sedimentary rocks: Am. Assoc. Petroleum Geologists Bull., v. 14 , no. 1, p. 1-24.

Bandy, O. L., and Ingle, J. C., Jr., 1970, Neogene planktonic events and radiometric scale, California: Geol. Soc. America Spec. Paper 124, p. 131-172.

Beal, A. O., Jr., and Fischer, A. G., 1969, Sedimentology, in Ewing, Maurice, and others, Initial reports of the Deep Sea Drilling Project: Washington, U.S. Govt. Printing Office, v. 1, p. 521-593.

Benfield, A. E., 1947, $A$ heat flow value for a well in California: Am. Jour. Sci., v. 245, no. 1, p. 1-18.

Berger, W. H., and von Rad, Ulrich, 1972, Cretaceous and Cenozoic sediments from the Atlantic Ocean, in Hayes, D. E., Initial reports Deep Sea Drilling Project: Washington, U.S. Govt. Printing Office, v. 14, p. 787-954.

Bramlette, M. N., 1946, The Monterey Formation of California and the origin of its siliceous rocks: U.S. Geol. Survey Prof. Paper 212, $57 \mathrm{p}$.

Briggs, Peter, 1971, 200,000,000 years beneath the sea: New York, Holt, Rinehart and Winston, 228 p.

Calvert, S. E., 1966, Accumulation of diatomaceous silica in the sediments of the Gulf of California: Geol. Soc. America Bull., v. 77, no. 6, p. 569-596.

1971, Composition and origin of North Atlantic deep sea cherts : Contr. Mineralogy and Petrology, v. 33, p. 273288.

Campbell, A. S., and Fyfe, W. S., 1960, Hydroxyl ion catalysis of the hydrothermal crystallization of amorphous silica; a possible high temperature $\mathrm{pH}$ indicator: $\mathrm{Am}$. Mineraloist, v. 45 , nos. 3-4, p. 464-468.

Creager, J. S., Scholl, D. W., and others, 1973, Initial reports of the Deep Sea Drilling Project: Washington, U.S. Govt. Printing Office, v. 19, p. 169-216.

Deep Sea Drilling Project, 1973, Leg 32: Geotimes, v. 18, no. 12, p. 14-17.

Dibblee, T. W., Jr., 1973, Stratigraphy of the southern Coast Ranges near the San Andreas fault from Cholame to Maricopa, California: U.S. Geol. Survey Prof. Paper 764, $45 \mathrm{p}$.

Eitel, Wilhelm, 1958. Structural conversions in crystalline systems and their importance for geological problems: Geol. Soc. America Spec. Paper 66, 183 p. 
Elliott, W. J., Tripp, Eugene, and Karp, S. E., 1968, West side oil fields and Temblor Range outcrop area, in Guidebook; Am. Assoc. Petroleum Geologists, Soc. Econ. Geophysicists,. and Soc. Econ. Paleontologists and. Mineralogists, Pacific Secs., 43d Ann. Mtg., 1968: p. 102-114.

Erickson, A., 1973, Initial report on downhole temperature and shipboard thermal conductivity measurements, Leg 19, in Creager, J. S., and others, Initial reports of the Deep Sea Drilling Project: Washington, U.S. Govt. Printing Office, v. 19 , p. 643-656.

Ernst, W. G., and Calvert, S. E., 1969, An experimental study of the recrystallization of porcelanite and its bearing on the origin of some bedded cherts: Am. Jour. Sci., v. 267A, p. 114-133:

Evans, T. R., and Coleman, N. C., 1974, North Sea geothermal gradients: Nature, v. 247 , no. 5435 , p. 28-30.

Evernden, J. F., Savage, D. E., Curtis, G. H., and James, G. T., 1964, Potassium-argon dates and Cenozoic mammalian chronology of North America: Am. Jour. Sci., v. 262, no. 2, p. $145-198$.

Floerke, O. W., 1955, Zur Frage des "Hoch"-Cristobalit in Opalen, Bentoniten and Glaesern: Neues Jahrb. Mineralogie Monatsh. 1955 , p. 217-233.

Foster, T. D., 1962, Heat-flow measurements in the Northeast Pacific and in the Bering Sea: Jour. Geophys. Research, v. 67, no. 7, p. 2991-2993.

Fournier, R. O., 1973, Silica in thermal waters: Laboratory and field investigations, in Internat. symposium on hydrogeochemistry and biogeochemistry, Tokyo, 1970: Washington, D.C., J. W. Clarke, Proc., v. 1, p. 122-139.

Gucluer, S. M., and Gross, M. G., 1964, Recent marine sediments in Saanich Inlet, a stagnant marine basin: Limnology and Oceanography, v. 9, p. 359-376.

Heath, R. G., and Moberly, Ralph, Jr., 1971, Cherts from the Western Pacific, Leg. 7, Deep Sea Drilling Project, in Winterer, E. L., and others, Initial reports of the Deep Sea Drilling Project: Washington, U.S. Govt. Printing Office, v. 7, page 991-1007.

Hedberg, H. D., 1936, Gravitational compaction of clays and shales: Am. Jour. Sci., v. 31, no. 184, p. 241-287.

Huffman, O. F., 1972, Lateral displacement of Upper Miocene rocks and the Neogene history of offset along the San Andreas fault in central California: Geol. Soc. America Bull., v. 83, p. 2913-2946.

Jones, J. B., Sanders, J. V., and Segnit, E. R., 1964, Structure of opal : Nature, v. 204, p. 990-991.

Jones, J. B., and Segnit, E. R., 1971, The nature of opal. 1. Nomenclature and constituent phases: Jour. Geol. Soc. Australia, v. 18, no. 1, p. 57-68.

- 1972, Genesis of cristobalite and tridymite at low temperatures: Jour. Geol. Soc. Australia, v. 18, pt. 4, p. 419422.

Lancelot, Yves, 1973, Chert and silica diagenesis in sediments from the central Pacific, in Winterer, E. L., Ewing, J. E., and others, Initial reports of the Deep Sea Drilling Project: Washington, U.S. Govt. Printing Office, v. 17, p. 377405.

Langseth, M. G., Jr., and Von Herzen, R. P., 1971, Heat flow through the floor of the world oceans, in Maxwell, A. E., ed., The Sea: New York, Wiley-Interscience, v. 4, p. 299352.

Lawver, L. A., Sclater, J. G., Henyey, T. L., and Rogers, J., 1973, Heat flow measurements in the southern portion of the Gulf of California : Earth and Planetary Sci. Letters, v. 12 , p. $198-208$ :

Lee, W. J. L., and Uyeda, Seiya, 1965, Review of heat flow data, in Lee, W. H. K., ed., Terrestrial heat flow: Am. Geophys. Union Geophys. Mon. 8, p. 87-190.

MčManus, D. A., and others, 1970, Introduction, initial reports of the Deep Sea Drilling Project: Washington; U.S. Govt. Printing Office, v. 5, p. 11-14.

Mizutani, Shinjiro, 1970, Silica minerals in the early stage of diagenesis: Sedimentology, v. 15, nos. 3-4, p. 419-436.

Moore, T. C., Jr., Heath, G. R., and Kowsmann, R. O., 1973, Biogenic sediments of the Panama Basin: Jour. Geology, v. 81, p. $458-472$.

Moses, P. L., 1962, Geothermal gradients : Am. Petroleum Inst. Drilling and Production Practice, 1961, p. 57-63.

Mulryan, Henry, 1936, Geology, mining, and processing of diatomite at Lompoc, Santa Barbara County, California : California Jour. Mines and Geology, v. 32, no. 2, p. 133166.

Murata, K. J., and Erd, R. C., 1964, Composition of sediments from the experimental Mohole project (Guadulupe site) : Jour. Sed. Petrology, v. 34, no. 3, p. 633-655.

Murata, K. J., and Nakata, J. K., 1974, Cristobalitic stage in the diagenesis of diatomaceous shale: Science, v. 184, p. $567-568$.

Pimm, A. C., Garrison, R. E., and Boyce, R. E., 1971, Sedimentary synthesis, in Fischer, A. G., and others, Initial reports of the Deep Sea Drilling Project: Washington, U.S. Govt. Printing Office, v. 6, p. 1173-1218.

Rex, R. W., 1969, X-ray mineralogy studies-leg 1, in Ewing, Maurice, and others, Initial reports of the Deep Sea Drilling Project: Washington, U.S. Govt. Printing Office, v. 1, p. 354-367.

Scholl, D. W., and Creager, J. S., 1973, Geologic synthesis of leg 19 (DSDP) results; Far North Pacific, Aleutian Ridge, and Bering Sea, in Creager, J. S., Scholl, D. W., and others, Initial reports of the Deep Sea Drilling Project: Washington, U.S. Govt. Printing Office, v. 19, p. 897-913.

Taliaferro, N. L., 1935, Some properties of opal: Am. Jour. Sci., ser. 5, v. 30 , p. $450-474$.

Turner, D. L., 1970, Potassium-argon dating of Pacific Coast Miocene foraminiferal stages: Geol. Soc. America Spec. Paper 124, p. 91-129.

Vedder, J. G., 1970, Geologic map of the Wells Ranch and Elkhorn Hills quadrangles, San Luis Obispo and Kern Counties, California, showing juxtaposed Cenozoic rocks along the San Andreas fault: U.S. Geol. Survey Misc. Geol. Inv. Map I-585.

Von Herzen, R. P., and Maxwell, A. E., 1964, Measurements of heat flow at the preliminary Mohole site of Mexico: Jour. Geophys. Research, v. 69, no. 4, p. 741-748.

White, D. E., Brannock, W. W., and Murata, K. J., 1956, Silica in hot-spring waters: Geochim. et Cosmochim. Acta, v. 10, p. 27-59.

Wise, S. W., Jr., Buie, B. F., and Weaver, F. M., 1972, Chemically precipitated sedimentary cristobalite and the origin of chert: Eclogae Geol. Helvetiae, v. 65, no. 1, p. 157-163.

Woodring, W. P., Stewart, R. B., and Richards, R. W., 1940, Geology of the Kettleman Hills oil field, California: U.S. Geol. Survey Prof. Paper 195, 170 p.

Zemmels, Ivar, and Cook, H. E., 1973, X-ray mineralogy of sediments from the northern Pacific and the Bering Sea, in Creager, J. S., Scholl, D. W., and others, Initial reports of the Deep Sea Drilling Project: Washington, U.S. Govt. Printing Office, v. 19, p. 667-697. 
Jour. Research U.S. Geol. Survey

Vol. 3, No. 5, Sept.-Oct. 1975, p. 567-572

\title{
SILICA MINERALOGY AND STRUCTURE OF THE MONTEREY SHALE, TEMBLOR RANGE, CALIFORNIA
}

\author{
By K. J. MURATA and R. G. RANDALL, Menlo Park, Calıf.
}

\begin{abstract}
The $d(101)$ spacing of diagenetic cristobalite decreases regularly with depth of burial in the siliceous Monterey Shale of the Temblor Range. This relation has been used to delineate the folded structure of the Monterey Shale at a locality near Taft.
\end{abstract}

The diagenetic transformation of metastable biogenic opal into stable quartz through intermediate cristobalite was recently studied by Murata and Nakata (1974) in thick stratigraphic sections of the Monterey Shale in the Temblor Range of California. As the rates of phase transformation are mainly a function of temperature and hence of depth of burial, these sections manifest, in descending order, three zones of progressively more advanced stages of transformation: (1) A biogenic opal zone, (2) a diagenetic cristobalite zone, and (3) a diagenetic quartz zone. These zones formed while the whole sedimentary pile lay at the bottom of the sea.

In a study of the siliceous Miocene sediments of the Bering Sea by Scholl and Creager (1973), what appears to be the top of zone 2 was detected in situ as a widespread seismic reflection horizon at subbottom depths of 500-700 m. At several sites, the horizon apparently trangresses the bedding at an angle of a few degrees, which led these authors to conclude that the horizon represents "some sore of a migratory diagenetic boundary related to the dissolution of diatoms and the formation of (cristobalitic) claystone."

In Monterey Shale of the Temblor Range, zone 2 is generally more than $800 \mathrm{~m}$ thick and is of unusual interest because diagenetic cristobalite undergoes a progressive ordering of its internal structure (Floerke, 1955; Jones and Segnit, 1971) with increasing depth of burial. As a result of the ordering process, the $d(101)$ spacing of cristobalite decreases from $4.11 \mathrm{~A}$ at the top of the zone to $4.04 \mathrm{~A}$ at the bottom.

Surfaces of constant $d(101)$ spacing, derived by contouring many determinations of the spacing over a given area, probably represent isothermal surfaces that prevailed within the cristobalitic zone of the submarine pile of siliceous sediments. Since these sur- faces are approximately concordant with the bedding, they might be used to divide an otherwise indivisible pile of cristobalitic rocks into several subunits for detailed studies. The Monterey Shale at Chico Martinez Creek has a simple homoclinal structure (Dibblee, 1973), and surfaces of constant $d(101)$ spacing there are roughly concordant with the bedding (Murata and Larson, 1975).

When strata become folded and faulted, the $d(101)$ surfaces could be similarly affected so that a map based on them might accurately delineate the resultant structures. In order to test this possibility, we sampled the Monterey Shale southwest of Taft (fig. 1), where it is moderately folded and faulted (Vedder, 1970).

The average rate of variation of the $d(101)$ spacing with depth of burial in the Taft area is not the same as that at Chico Martinez Creek (fig. 2). Assuming that temperatures at the top and bottom of the cristobalitic diagenetic zone were the same in the two areas, the curves in figure 2 can be viewed as representations of two different geothermal gradients as recorded in the crystal structure of cristobalite. The need for establishing many more curves of this kind is obvious.

Acknowledgments.-We are indebted to C. L. Christ for an analysis of the X-ray diffraction pattern of quartz at high $2 \theta$ angles and to J. G. Vedder for a collation of foraminiferal data on the Monterey Shale of the Taft area.

\section{MONTEREY SHALE OF THE TAFT AREA}

The structure of the Temblor Range southwest of Taft (Vedder, 1970) is dominated by the Gonyer anticline, whose axis parallels the general northwest trend of the range (fig. 3). Landslide deposits obliterate much but not all of the geology along the crest of the anticline. The Monterey Shale is about $3 \mathrm{~km}$ thick in this region and is not only arched in the main anticlinal fold but also crumpled and broken by several secondary folds and faults. Ninety-eight samples of siliceous porcelanite were collected from the Monterey Shale on both sides of the Gonyer anticline, and their 


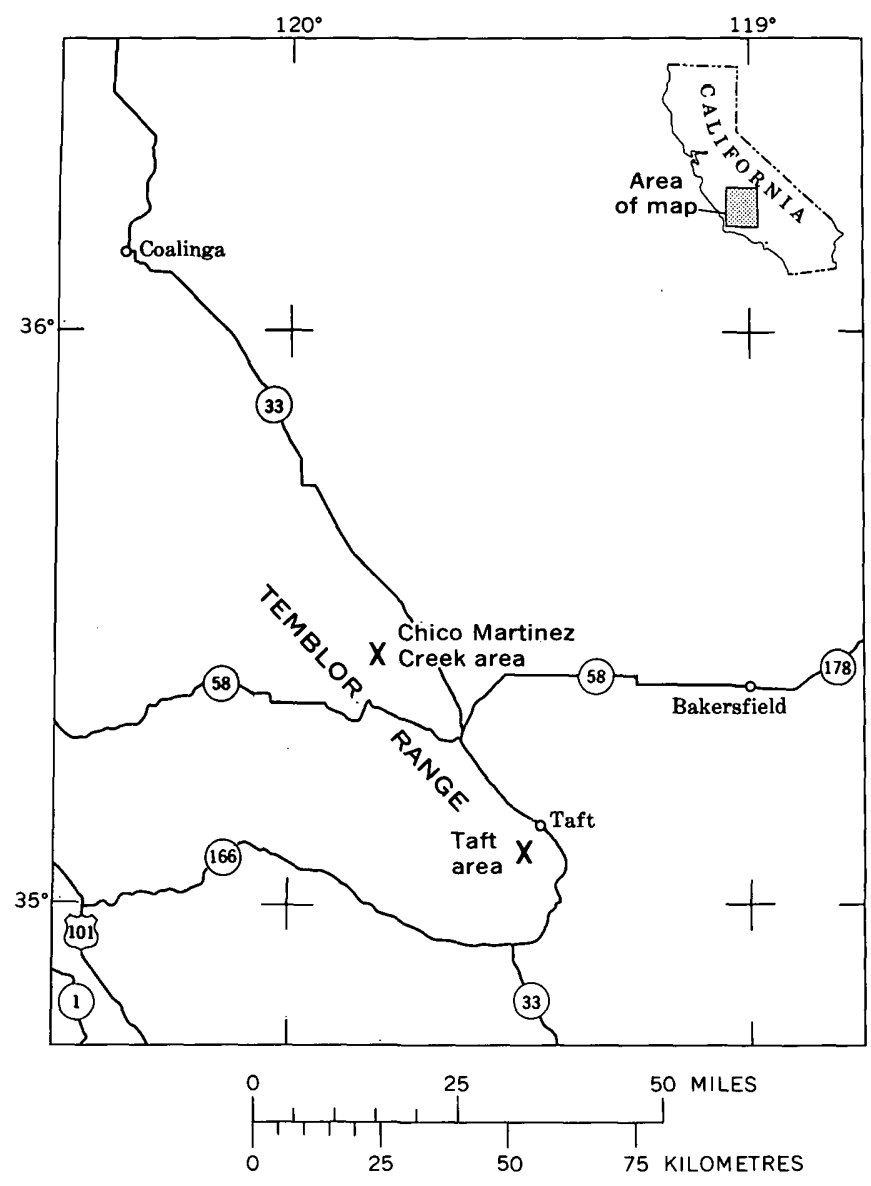

Figure 1.-Index map of part of California showing the studied area southwest of Taft and the reference area at Chico Martinez Creek.

silica mineralogy was determined by means of the $\mathrm{X}$-ray diffractometer. The $d(101)$ spacing of cristobalite in 79 samples found to be cristobalitic was then determined, using quartz as internal standard; the spacings are listed in table 1.

TABLE 1.- $\mathrm{d}(101)$ spacing, in angstroms, of diagenetic cristobalite in the Monterey Shale southwest of Taft

[Samples are plotted in fig. 4]

\begin{tabular}{cc|cc|cc|cc}
\hline Sample & $d(101)$ & Sample & $d(101)$ & Sample & $d(101)$ & Sample & $d(101)$ \\
\hline 1 & 4.110 & 21 & 4.090 & 41 & 4.075 & 61 & 4.047 \\
2 & 4.092 & 22 & 4.079 & 42 & 4.071 & 62 & 4.037 \\
3 & 4.075 & 23 & 4.092 & 43 & 4.080 & 63 & 4.042 \\
4 & 4.057 & 24 & 4.073 & 44 & 4.064 & 64 & 4.047 \\
5 & 4.049 & 25 & 4.077 & 45 & 4.064 & 65 & 4.040 \\
6 & 4.040 & 26 & 4.068 & 46 & 4.047 & 66 & 4.044 \\
7 & 4.044 & 27 & 4.055 & 47 & 4.066 & 67 & 4.051 \\
8 & 4.047 & 28 & 4.055 & 48 & 4.057 & 68 & 4.066 \\
9 & 4.046 & 29 & 4.088 & 49 & 4.046 & 69 & 4.040 \\
10 & 4.042 & 30 & 4.082 & 50 & 4.051 & 70 & 4.053 \\
11 & 4.038 & 31 & 4.071 & 51 & 4.044 & 71 & 4.080 \\
12 & 4.039 & 32 & 4.080 & 52 & 4.058 & 72 & 4.066 \\
13 & 4.047 & 33 & 4.046 & 53 & 4.042 & 73 & 4.088 \\
14 & 4.068 & 34 & 4.077 & 54 & 4.042 & 74 & 4.097 \\
15 & 4.066 & 35 & 4.075 & 55 & 4.044 & 75 & 4.101 \\
16 & 4.088 & 36 & 4.075 & 56 & 4.071 & 76 & 4.108 \\
17 & 4.092 & 37 & 4.075 & 57 & 4.051 & 77 & 4.107 \\
18 & 4.092 & 38 & 4.069 & 58 & 4.046 & 78 & 4.099 \\
19 & 4.088 & 39 & 4.066 & 59 & 4.044 & 79 & 4.110 \\
20 & 4.073 & 40 & $\mathbf{4 . 0 6 0}$ & $\mathbf{6 0}$ & 4.046 & & \\
\hline
\end{tabular}

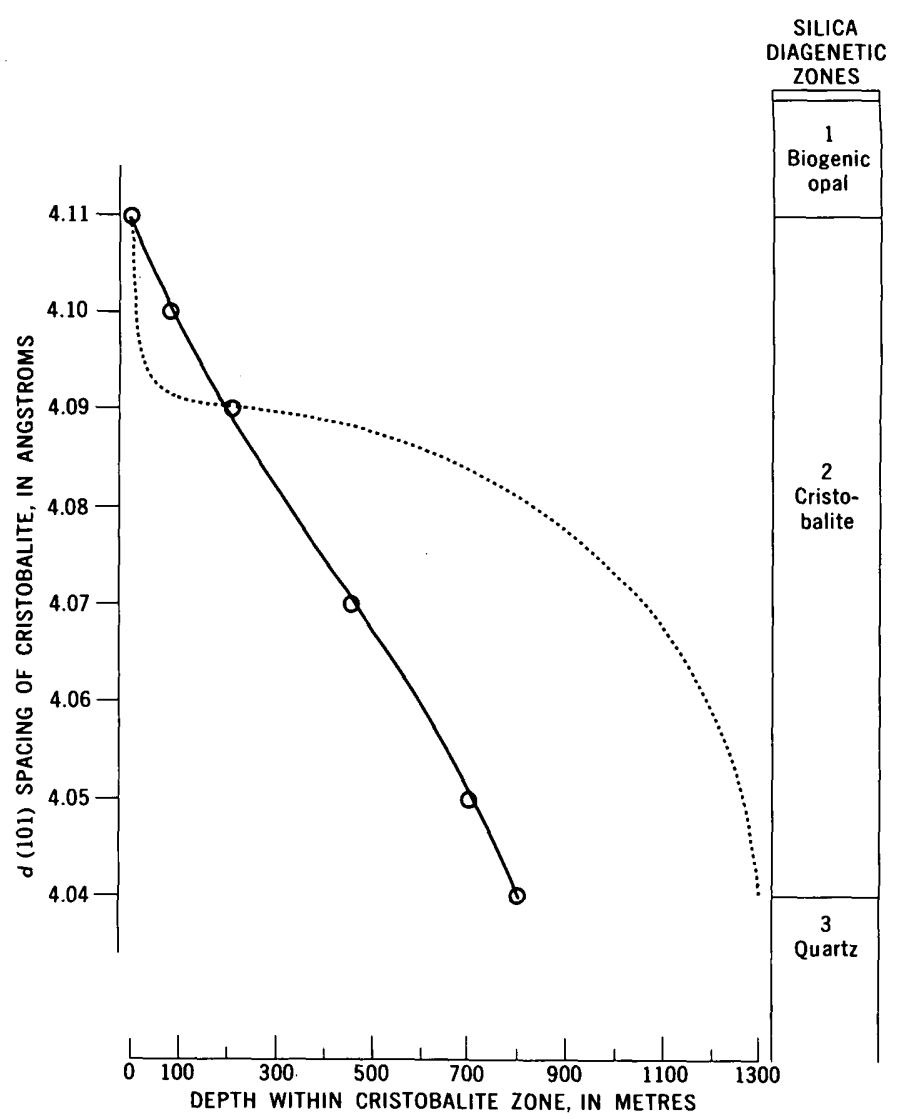

Figure 2.-The three diagenetic zones of Monterey Shale characterized by different forms of silica, and the variation with depth of the $d(\mathbf{1 0 1 )}$ spacing of cristobalite in porcelanites of the Taft area (solid line) and of Chico Martinez Creek (dotted line, from Murata and Nakata, 1974).

\section{RELATION OF THE $d(101)$ SPACING OF CRISTOBALITE TO STRUCTURE OF MONTEREY SHALE}

The mineralogy of the 98 samples of porcelanite is plotted in figure 4, and Monterey Shale is seen to be divisible broadly into cristobalitic and quartzose diagenetic zones. Contours of the $d(101)$ spacing of cristobalitic samples show a general down-section decrease of the spacing, as was noted earlier at Chico Martinez Creek. However, at the Taft area, unlike the area at Chico Martinez Creek, spacings smaller than 4.07 A give contours that deviate considerably from the regional trend of Temblor Range because of local irregularities in structure. In this preliminary study, we could not help but be influenced by the structural data given in figure 3 in contouring the $d(101)$ spacings in figure 4. However, the $d(101)$ contours do offer a new way of determining the structure of siliceous shales and seem to throw light on some structural relations that hitherto were obscure. 


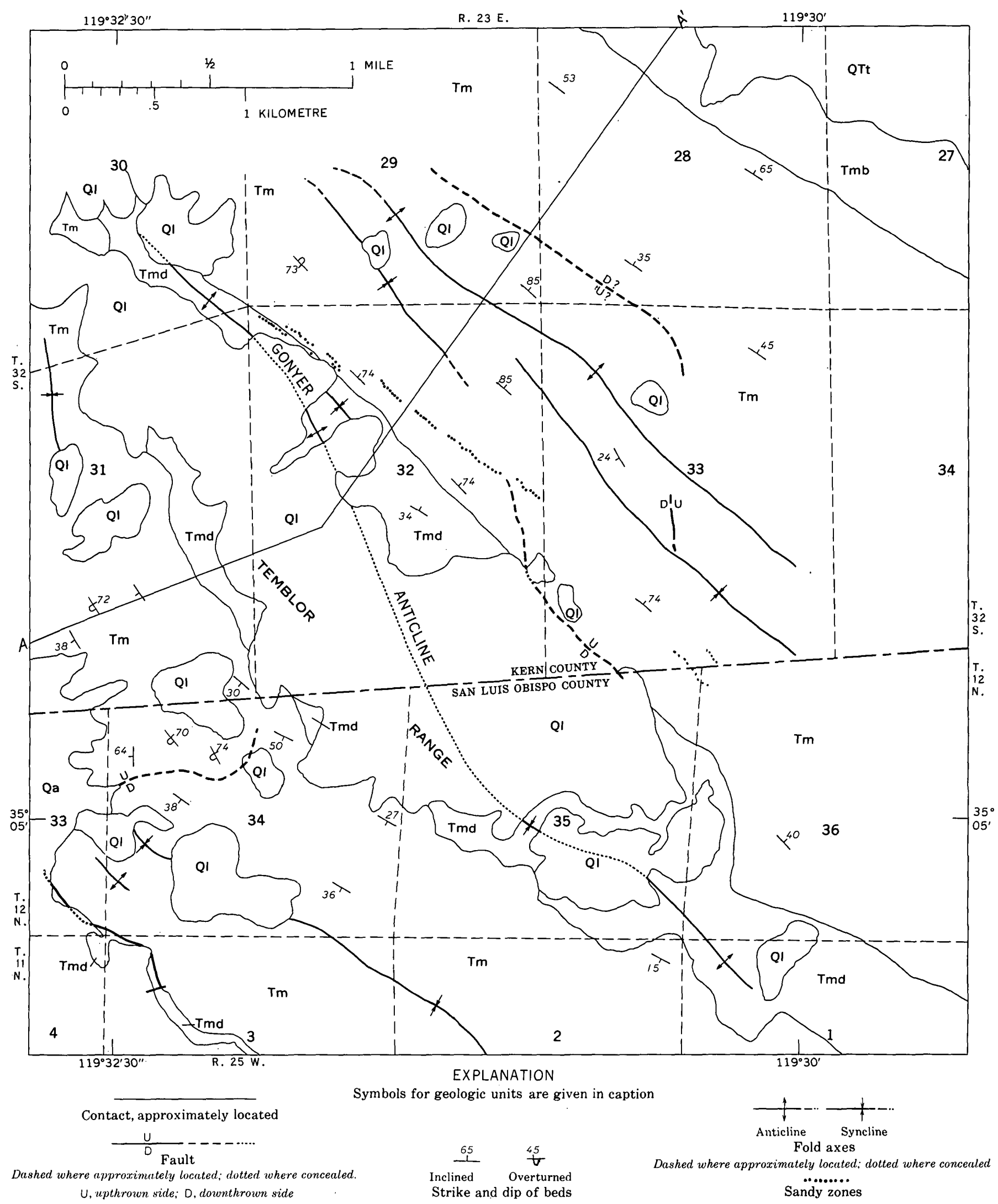

Figure 3.-Geologic map of the Temblor Range southwest of Taft, from Vedder (1970). The mapped units are QI, Holocene landslide deposits; Qa, Holocene alluvial deposits; QTt, Pliocene and Pleistocene Tulare Formation; and three members of the Miocene Monterey Shale; Tmb, Belridge Diatomite Member; Tm, McLure Shale Member; and Tmd, Devil-

water Shale Member. A structure section along line $A-A^{\prime}$ is given in figure 5. The unusual sequence of section numbers arises from the fact that the area lies along the boundary between land surveys based on Mount Diablo to the northwest and those based on San Bernardino to the southeast. 


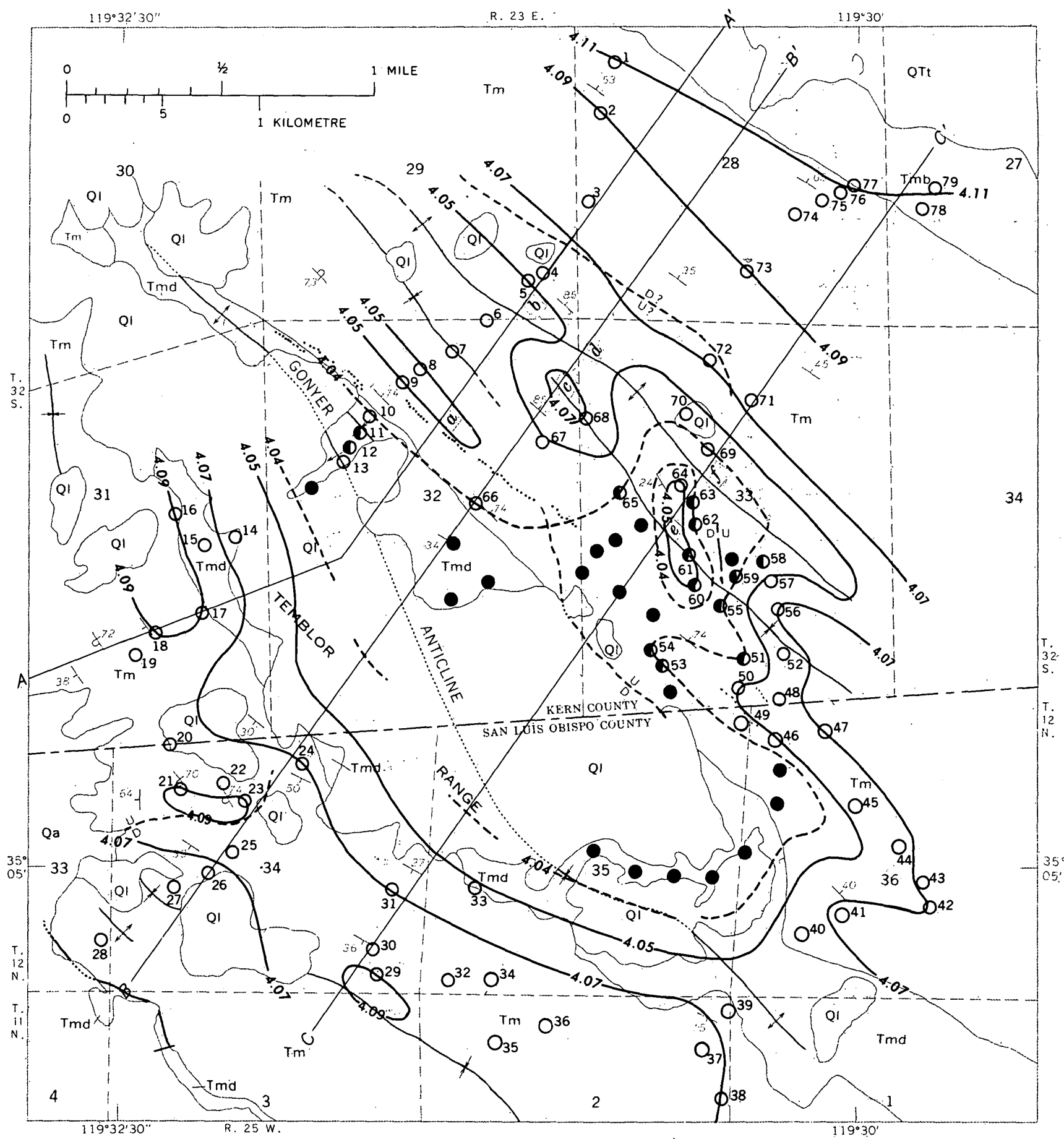

Fraure 4.-Locality and mineralogy of numbered samples. (listed in table 1) of siliceous porcelanite collected from the Monterey Shale southwest of Taft: The silica mineralogy of the samples is shown by open. circles that denote cristobalite; half-filled circles, mixed" cristobàlite-quartz; and

Figure 5.-Structure section and profiles of $d(101)$ cristobalite spacings in rocks of the Temblor Range near Taft. Formation symbols are the same as in figure 3 with the addition of Ttu, upper part of the Temblor Formation (Tertiary). Dots indicate sandier parts of the sedimentary units. $A$, Structure section along line $A-A^{\prime}$-in figures 3 and 4 , from filled circles, quartz. Values of $d(101)$ spacing of cristobalite are contoured at intervals of $0.02 \cdot \mathrm{A}$, except for the spacing between 4.05 and $4.04 \mathrm{~A}$ which is shown as a dashed line. Profiles of $d$-spacings drawn along $A-A^{\prime}, B-B^{\prime}$, and $C-C^{\prime}$ are shown in figure 5 .

Vedder (1970). B, Projections of the $d(101)$ spacings, in angstroms, above the structure section of $A . C, D$, and $E$, Profiles of $d(101)$ spacing along lines $A-A^{\prime}, B-B^{\prime}$, and $C-C^{\prime}$ in figure 4. The scale for the spacing has been inverted so that values for rocks raised from greatest depth will plot "highest in the profile. 
MURATA AND RANDALL
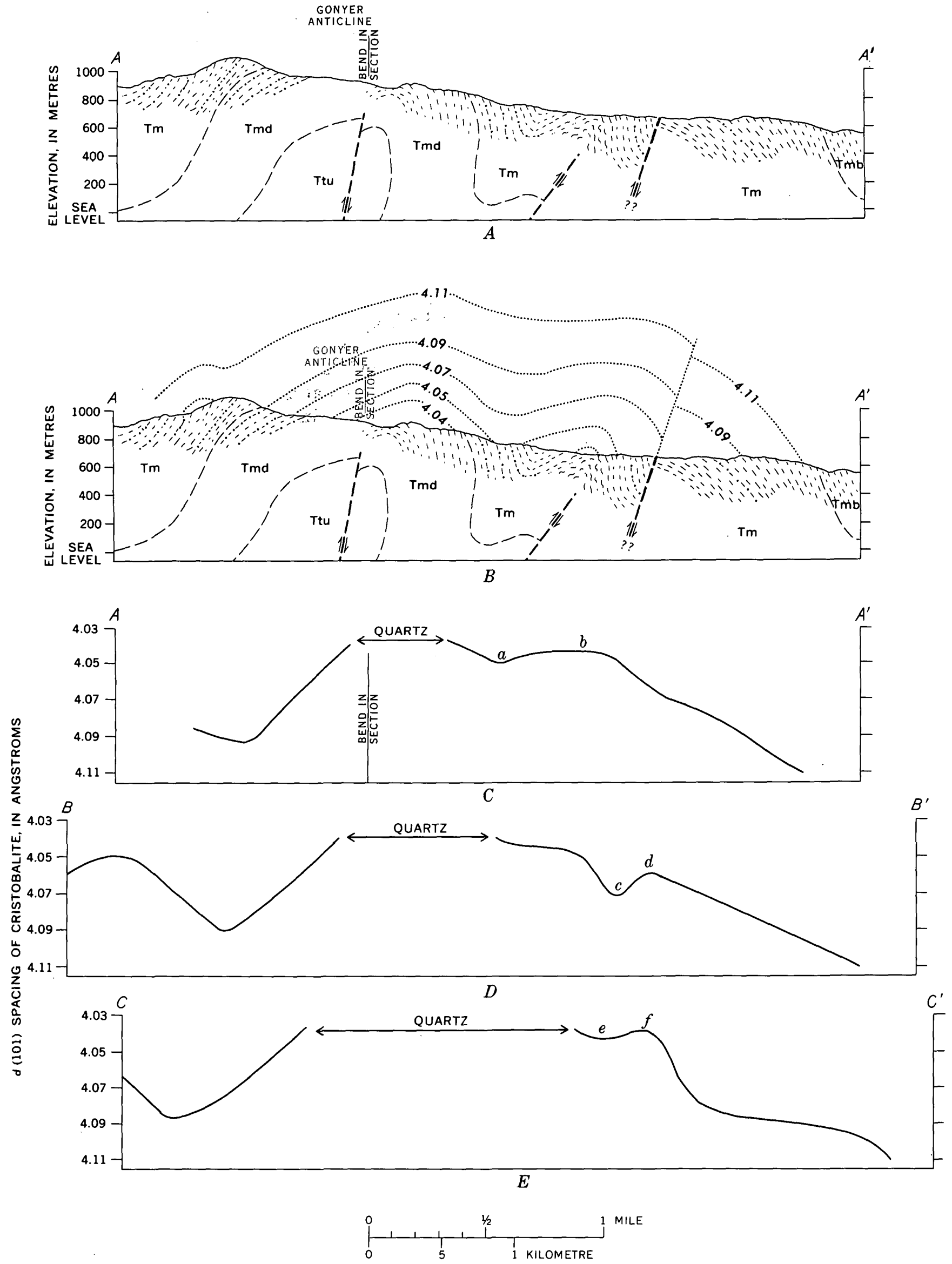
The location of Gonyer anticline is well defined by the silica mineralogy of the Monterey Shale in the Taft area (figs. 4 and 5). Strata bearing diagenetic quartz are exposed in the axial part of the fold throughout most of the area. Where only cristobalitic strata are exposed, the anticlinal axis is indicated by minimum $d(101)$ values. The disappearance of the quartz zone along the anticlinal axis in the southeastern corner of the area probably is due to the plunge of the anticline in that direction. A major syncline to the west of the Gonyer anticline appears in figure 4 as a roughly linear belt of high $d(101)$ values (4.07-4.09 A). The syncline is indicated in each $d(101)$ profile in figure 5 as a broad trough near the left margin.

Besides these major features, the $d(101)$ contours reflect the presence of smaller folds on the east limb of the Gonyer anticline. The anticline and syncline in the northeast corner of section 32 are indicated in profile $A-A^{\prime}$ (fig. $5 C$ ) by a broad peak $(b)$ and trough $(a)$, respectively. These small folds appear as somewhat more distinct peaks $(d, f)$ and troughs $(c, e)$ in profiles $B-B^{\prime}$ (fig. $5 D$ ) and $C-C^{\prime}$ (fig. $5 E$ ). In general, no direct relation between silica mineralogy and faulting can be demonstrated in the Taft area.

An uncertain aspect of this study is the locally poor correlation between silica mineralogy and the boundary between the McLure Shale Member and the underlying, more sandy, Devilwater Shale Member, both within the Monterey. For example, in the northwest corner of sec. 32 , T. 32 S., R. 23 E. (fig. 4), cristobalitic samples along this boundary have $d(101)$ values of about $4.04 \mathrm{~A}$. On the opposite flank of the Gonyer anticline in sec. 31 , samples along this boundary have $d(101)$ values of $4.07-4.09$ A. Figure $5 B$ shows that the differing values of the spacing along the Devilwater-McLure boundary on the two limbs of the anticline result from an asymmetric disposition of the lines of constant spacings, relative to the anticlinal axis.

The isothermal surfaces represented by $d(101)$ spacings of $4.05-4.09 \mathrm{~A}$ (fig. $5 B$ ) lie within the McLure to the east but are within the Devilwater to the west. This relation suggests that parts of the two members may have been deposited contemporaneously, the Devilwater part being the sandier western facies and the McLure part the more clayey eastern facies. With such transitional sediments, the generally higher thermal conductivity of sandy over clayey materials may also have been a factor in depressing isothermal surfaces to the west. Foraminiferal ages, as determined from sparse sampling in the two sedimentary units, are not sufficiently refined to prove or disprove the suggestion that the units may be partly contemporaneous (J. G. Vedder, oral commun., August 1974).

Another discrepancy between silica mineralogy and the Devilwater-McLure boundary arises from the occurrence of diagenetic quartz in the McLure in sec. 33, T. 32 S., R. 23 E., and in the northwestern corner of sec. 36 , T. 12 N., R. 25 W. (fig. 4), whereas elsewhere diagenetic quartz is apparently restricted to the Devilwater. J. G. Vedder (oral commun., August 1974) has suggested that some of the discrepancy could be removed by shifting the Devilwater-McLure boundary slightly to the northeast in this area, perhaps parallel to the sandy zones mapped by him as thin dotted lines in sec. 32 and at the bottom of sec. 33 (fig. 3).

This preliminary study suggests that the geologic structure of siliceous shale formations that contain diagenetic cristobalite can be delineated by means of the $d(101)$ spacing of the cristobalite. More information is needed on how consistently the changing crystal structure of cristobalite records the maximum temperature to which it has been subjected and what factors other than temperature might alter the rate of change of the structure.

\section{REFERENCES CITED}

Dibblee, T. W., Jr., 1973, Stratigraphy of the southern Coast Ranges near the San Andreas fault from Cholame to Maricopa, California: U.S. Geol. Survey Prof. Paper 764, 45 p.

Floerke, O. W., 1955, Zur Frage des "Hoch"-Cristobalit in Opalen, Bentoniten und Glaesern: Neues Jahrb. Mineralogie Monatsh. 1955, p. 217-233.

Jones, J. B., and Segnit, E. R., 1971, The nature of opal. 1. Nomenclature and constituent phases: Jour. Geol. Soc. Australia, v. 18, no. 1, p. 57-68.

Murata, K. J., and Larson, R. R., 1975, Diagenesis of Miocene siliceous shales, Temblor Range, California: U.S. Geol. Survey Jour. Research, v. 3. (In press.)

Murata, K. J., and Nakata, J. K., 1974, Cristobalitic stage in the diagenesis of diatomaceous shale: Science, v. 184, p. $567-568$.

Scholl, D. W., and Creager, J. S., 1973, Geologic synthesis of leg 19 (DSDP) results; Far North Pacific, Aleutian Ridge, and Bering Sea, in Creager, J. S., Scholl, D. W., and others, Initial reports of the Deep Sea Drilling Project: Washington, U.S. Govt. Printing Office, v. 19, p. 897-913.

Vedder, J. G., 1970, Geologic map of the Wells Ranch and Elkhorn Hills quadrangles, San Luis Obispo and Kern Counties, California, showing juxtaposed Cenozoic rocks along the San Andreas fault: U.S. Geol. Survey Misc. Geol. Inv. Map I-585. 


\title{
TECTONIC SETTING OF THE TERTIARY VOLCANIC ROCKS OF THE OLYMPIC PENINSULA, WASHINGTON
}

\author{
By WALLACE M. CADY, Denver, Colo.
}

\begin{abstract}
Lower and middle Eocene abyssal and Hawaiian type tholeiitic basalts form two accumulations that apparently were once far out on the east flank of the Juan de Fuca Ridge, within the Juan de Fuca plate. One of these (more than 15 $\mathrm{km}$ thick) is near the eastern and southeastern periphery of the Olympic Peninsula, and the other (about $5 \mathrm{~km}$ thick) is on the north. The tholeiites stratigraphically overlie and interfinger with Paleocene(?) and lower and middle Eocene marine turbidites and shales; one flow includes boulders that, like clasts in the sediments, were derived from the North American continental plate immediately to the east. The basalts are overlain stratigraphically by middle Eocene to middle Miocene clastic marine sedimentary rocks, which are in turn overlapped unconformably on the south and west by upper Miocene(?) and Pliocene, chiefly shallow-marine clastic rocks. These various peripheral rocks flank a middle or late Miocene structurally complex dome, or orocline convex to the east, in which originally east dipping and low angle late Eocene to late Miocene underthrusts are flexed. The outermost underthrust of the complex separates the chiefly volcanic peripheral rocks to the north, east, and south from stratigraphically correlative and comparable, though predominantly sedimentary, core rocks arranged in northwest trending arcuate belts or packets bounded by fault zones. Before underthrusting, and perhaps oroclinal folding connected with doming, the pre-middle Miocene section was possibly 150 to $200 \mathrm{~km}$ wide compared with the present Olympic Peninsula which is $120 \mathrm{~km}$ wide. The section accumulated on the ocean floor near the western margin of the continent, before and during subduction of the oceanic crust.
\end{abstract}

Perhaps the thickest known section of mafic marine volcanic rocks in the world is found in the eastern periphery of the Olympic Peninsula, Wash. (fig. 1), where an apparently unbroken section of more than $15 \mathrm{~km}$ of lower Tertiary basalt, which stands almost vertically with tops east, is exposed in the deeply cut valleys of several rivers that flow eastward toward Puget Sound. Basalts of the Olympic Peninsula are chiefly oceanic tholeiite as opposed to alkali basalt, as indicated by their contents of $\mathrm{K}_{2} \mathrm{O}<0.50, \mathrm{TiO}_{2}=2.0$ or less, $\mathrm{P}_{2} \mathrm{O}_{5}=0.36$ or less (table 1 ), and rare-earth elements (Glassley, 1974, figs. 7, 8). The ratio $\left(\mathrm{Na}_{2} \mathrm{O}+\mathrm{K}_{2} \mathrm{O}\right) / \mathrm{SiO}_{2}$ indicates that the compositions of the most of the samples collected fall in the field of Hawaiian tholeiites (fig. $2 A$ ), transitional from abyssal tholeiites to alkali basalt (fig. $2 B$ ), although plots of $\mathrm{TiO}_{2}$ versus $\left(\mathrm{Fe}_{2} \mathrm{O}_{3}+\mathrm{FeO}\right) / \mathrm{MgO}$ suggest predominance of abyssal (ridge) tholeiite (fig. $2 C$ ). High alkali-silica ratios in some of these rocks can possibly be attributed to metasomatism that may have occurred both during and after extrusion. The relatively high alkalisilica ratios of the comparatively thin basaltic units in the core rocks of the Olympic Peninsula (fig. 2A) suggest easier access of seawater in prolonged intervals during and between times of extrusion.

The basalt of the Olympic Peninsula differs from all known ridge tholeiites in that it is many times thicker, and interfingers laterally with and is underlain stratigraphically by sedimentary rocks (Cady, Sorensen, and MacLeod, 1972; Cady, Tabor, and others, 1972; Tabor and others, 1972). These rocks are most notably turbidites, whose continental provenance is shown particularly by detrital quartz including quartzite and chert, and in some places by detrital muscovite. The basalt also differs from most ridge tholeiites, except for example those of Iceland, in that its upper third ranges from a deep-to-shallow marine environment to one that is locally terrestrial, especially near the top (Cady, Sorensen, and MacLeod, 1972; Cady, Tabor, and others, 1972; Tabor and others, 1972; Rau, 1964, p. G3-G4; see also Snavely and others, 1968). The basalt's thickness, proximity to the continent, and position well east of the crest of the Juan de Fuca Ridge, at the time of extrusion, are each very significant.

Most of the volcanic rocks crop out near the periphery of the Olympic Peninsula, in a horseshoe pattern convex to the east, and surrounding the Olympic Mountains on the north, east, and south (fig. 1). This article discusses, first, peripheral rocks and then those of the core of the Olympic Mountains and to the west; finally it examines structural history and provenance of the rocks, including regional pretectonic restoration.

The progress of this and related studies have been reported almost yearly in summaries of Geological Survey research (U.S. Geol. Survey, 1963, p. A96; 1964, p. A110; 1965, p. A96; 1966, p. A87; 1969, p. 

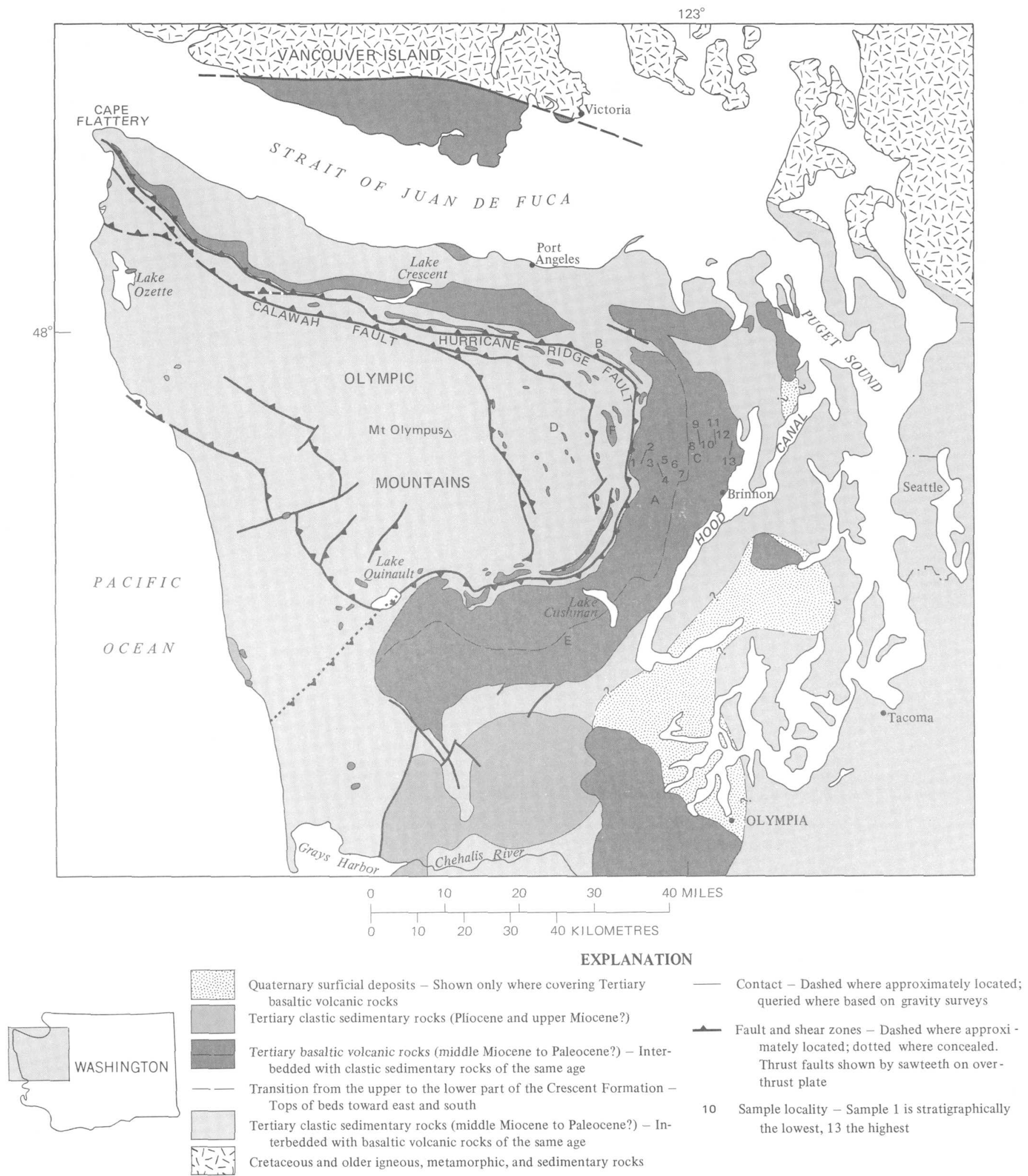

Figure 1.-Geologic map of the Olympic Peninsula, Wash., and vicinity, showing distribution and tectonic relationships of the Tertiary volcanic rocks. Letters A-F indicate locations of geographic features identified in table 1. 
TABLE 1.-Average compositions of the basalts of the Olympic Peninsula, Washington, compared with oceanic tholeiitic basalts, with alkali basalts from seamounts and islands, and with Hawaiian tholeiitic basalt

[Compositions of individual samples of Olympic mafic rocks showing probable minimum alkali metasomatism are supplied; composition of those Individual samples of Olymple mafic rocks that are most nearly like the oceanic tholelites, alkali basalts, and Hawatian , tholelites are also
supplied. D.I., differentiation index]

\begin{tabular}{|c|c|c|c|c|c|c|c|c|c|c|c|c|c|}
\hline & \multicolumn{8}{|c|}{ Olympic Peninsula } & \multirow{3}{*}{\multicolumn{2}{|c|}{$\begin{array}{c}\text { Oceanic } \\
\text { tholeilte } \\
\end{array}$}} & \multirow{3}{*}{\multicolumn{2}{|c|}{$\begin{array}{l}\text { Senmounts } \\
\text { and islunds } \\
\text { alkali } \\
\text { basalt } \\
\end{array}$}} & \multirow[b]{4}{*}{$\begin{array}{c}\text { Hawallan } \\
\text { tholelite } \\
\text { (Aver- }^{\text {age }} \\
\text { age }^{3}\end{array}$} \\
\hline & \multicolumn{4}{|c|}{ Crescent Formation : lower two-thirds } & \multicolumn{2}{|c|}{$\begin{array}{c}\text { Crescent } \\
\text { Formation : } \\
\text { upper third } \\
\end{array}$} & \multirow{2}{*}{\multicolumn{2}{|c|}{ Core rocks }} & & & & & \\
\hline & South & reast & & North & Sou & itheast & & & & & & & \\
\hline & $\begin{array}{l}\text { Average } \\
\text { of } 30 \\
\text { samples }\end{array}$ & $\begin{array}{c}\text { Lowest } \\
\text { alkall/ } \\
\text { sillca } \\
(\mathrm{BC}-65- \\
105)^{1}\end{array}$ & $\begin{array}{c}\text { Average } \\
\text { of } 7 \\
\text { samples }\end{array}$ & $\begin{array}{c}\text { Lowest } \\
\text { alkali/ } \\
\text { silica } \\
(\mathrm{RW} T-27- \\
64)^{1}\end{array}$ & $\begin{array}{c}\text { Average } \\
\text { of } 32 \\
\text { samples }\end{array}$ & $\begin{array}{l}\text { Lowest } \\
\text { alkall/ } \\
\text { silica } \\
(\mathrm{T}-12)^{1}\end{array}$ & $\begin{array}{l}\text { Average } \\
\text { of } 19 \\
\text { simples }\end{array}$ & $\begin{array}{c}\text { Lowest } \\
\text { alkali/ } \\
\text { silica } \\
\left(\begin{array}{c}\text { W } W^{\prime}-126- \\
68)^{1}\end{array}\right.\end{array}$ & $\begin{array}{l}\text { Aver- } \\
\text { age 2 }\end{array}$ & $\begin{array}{c}\text { Most } \\
\text { similar } \\
\text { sample } \\
\text { from } \\
\text { olymple } \\
\text { Peninsula } \\
(O C-891)^{1}\end{array}$ & $\begin{array}{l}\text { Aver- } \\
\text { age } 2\end{array}$ & $\begin{array}{c}\text { Most } \\
\text { similar } \\
\text { sample } \\
\text { from } \\
\text { olymple } \\
\text { Pentnsula } \\
\text { TC-6.3- } \\
208)^{1-} \\
\end{array}$ & \\
\hline 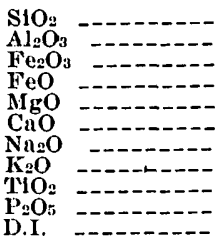 & $\begin{array}{r}49.34 \\
15.05 \\
3.14 \\
8.57 \\
8.36 \\
10.56 \\
2.82 \\
.49 \\
1.46 \\
.21 \\
26.78\end{array}$ & $\begin{array}{r}49.99 \\
13.63 \\
3.28 \\
10.86 \\
6.56 \\
11.99 \\
1.84 \\
.20 \\
1.43 \\
.22 \\
20.11\end{array}$ & $\begin{array}{r}51.41 \\
15.68 \\
4.05 \\
7.48 \\
5.71 \\
9.04 \\
4.05 \\
.45 \\
1.77 \\
.36 \\
36.94\end{array}$ & $\begin{array}{r}51.68 \\
14.32 \\
1.35 \\
10.90 \\
7.68 \\
9.03 \\
3.42 \\
.06 \\
1.45 \\
.11 \\
29.34\end{array}$ & $\begin{array}{r}49.14 \\
14.99 \\
4.27 \\
7.91 \\
7.18 \\
10.83 \\
3.02 \\
.34 \\
2.08 \\
.24 \\
27.58\end{array}$ & $\begin{array}{r}49.17 \\
14.39 \\
4.55 \\
8.07 \\
7.66 \\
11.18 \\
1.86 \\
.35 \\
2.48 \\
0.27 \\
22.20\end{array}$ & $\begin{array}{r}48.67 \\
16.15 \\
2.01 \\
9.29 \\
8.55 \\
9.61 \\
3.45 \\
.40 \\
1.58 \\
.25 \\
31.59\end{array}$ & $\begin{array}{r}51.00 \\
14.02 \\
4.05 \\
8.93 \\
5.82 \\
11.53 \\
3.32 \\
.06 \\
1.14 \\
.11 \\
28.98\end{array}$ & $\begin{array}{r}50.02 \\
17.27 \\
2.02 \\
6.91 \\
7.29 \\
11.88 \\
2.77 \\
.16 \\
1.51 \\
.16 \\
24.38\end{array}$ & $\begin{array}{r}49.41 \\
16.19 \\
3.84 \\
5.92 \\
7.78 \\
13.18 \\
2.39 \\
.15 \\
1.04 \\
.10 \\
21.66\end{array}$ & $\begin{array}{r}48.24 \\
18.34 \\
4.24 \\
5.90 \\
4.87 \\
8.80 \\
4.06 \\
1.69 \\
2.92 \\
.94 \\
43.23\end{array}$ & $\begin{array}{r}48.34 \\
17.30 \\
5.03 \\
7.13 \\
6.19 \\
7.97 \\
3.77 \\
1.68 \\
1.99 \\
.60 \\
41.65\end{array}$ & $\begin{array}{r}49.92 \\
14.11 \\
3.06 \\
8.62 \\
8.53 \\
10.52 \\
2.15 \\
.38 \\
2.52 \\
.26 \\
22.32\end{array}$ \\
\hline
\end{tabular}

1 Sample localities and distance and azimuth from a geographic feature indicated by letter symbols A-F, figure 1 , are as follows BC-65-105, near Duckabush River; $1.7 \mathrm{~km} 350^{\circ}$ from $\mathrm{St}$. Peters Dome (A). RWT-126-68, near Hayden Pass; $1.29 \mathrm{~km} 163^{\circ}$ from Mount RWT-27-64, near Deer Park; $1.13 \mathrm{~km} 166^{\circ}$ from Blue Mountain (B).

T-12, near Qullcene River; $1.2 \mathrm{~km} 40^{\circ}$ from Mount Crag (C). Claywood (D).

OC-891, near North Fork of Skokomish River; $0.7 \mathrm{~km} 46^{\circ}$ from Rock Peak (E)

TC-63-208, on The Needles; $2.6 \mathrm{~km} 358^{\circ}$ from Mount Decep-

2 Engel and others (1965, table 2, p. 721)

3

A46-A48; 1970, p. 43; 1971, p. A48; 1972, p. A47-A48; 1973, p. 62 ).

Acknowledgments.-The author is indebted especially to R. W. Tabor, whose mapping of the core rocks has been essential to the understanding of the tectonic relationships of the Olympic Peninsula. Other field associates and colleagues, some included in the list of references-W. O. Addicott, V. J. Ansfield, Dana Brasilin, R. D. Brown, F. W. Cater, R. E. Garrison, Jr., William Glassley, H. D. Gower, D. D. Hastings, A. D. Horn, N. S. MacLeod, M. S. Miller, J. D. Obradovich, W. W. Rau, P. D. Snavely, Jr., M. L. Sorensen, R. J. Stewart, and R. S. Yeats-provided valuable contributions, oral as well as written. Z. E. Peterman and Mitsunobu Tatsumoto added very profitable oral suggestions regarding the geochemistry of oceanic tholeiites. Many others have contributed, including J. R. Balsley, H. L. James, J. M. Nelson, C. F. Park, Jr., R. J. Roberts, J. W. Robinson, J. M. Straczek, and R. G. Yates, during initial studies by the Geological Survey in $1938-40$.

\section{PERIPHERAL ROCKS OF THE OLYMPIC "HORSESHOE"}

The lower and middle Eocene (Rau, 1964, p. C4; N. S. MacLeod, oral commun., 1973) Crescent Formation, which makes up a large part of the map unit called "Tertiary basaltic volcanic rock" of figure 1 , near the periphery of the Olympic Peninsula on the north, east, and south (fig. 1), contains most of the volcanic rocks of the peninsula. This formation is more than
$15 \mathrm{~km}$ thick in eastern exposures, but thins to the west and south, chiefly by tapering of the volcanic units. Associated with the volcanic rocks are small amounts of turbidites and shales that include rocks perhaps as old as Paleocene, as much as $2 \mathrm{~km}$ stratigraphically beneath the volcanic rocks in most of the eastern part of the peninsula. Gradation and interbedding at the stratigraphic upward transition from sedimentary to volcanic rocks may be studied near roads and trails northwest of Lake Cushman (fig. 1). The sedimentary rocks beneath the volcanic rocks bottom at a fault at the outer border of the core rocks of the Olympic Mountains (Cady, Sorensen, and MacLeod, 1972; Cady, Tabor, MacLeod, and Sorensen, 1972; Tabor and others, 1972). The only known ultramafic rocks in the peninsula-two very small bodies of serpentinized feldspathic peridotite (Miller, 1967, p. 35-37) - and some hornblende diorite dikes intrude the sedimentary rocks that underlie the volcanic rocks northwest of Lake Cushman.

The Crescent volcanic rocks apparently include two separate centers of accumulation, one in the eastern to southeastern part of the Olympic Peninsula and adjacent areas where the rocks are more than $15 \mathrm{~km}$ thick, and another in the northern part where rocks are only $5 \mathrm{~km}$ thick (fig. 1). At the northeastern corner of the peninsula, between these two centers, are marine turbidites and shales of the Crescent Formation that interfinger laterally with the thick accumulations of basalt. The intervening. sedimentary rocks continue 


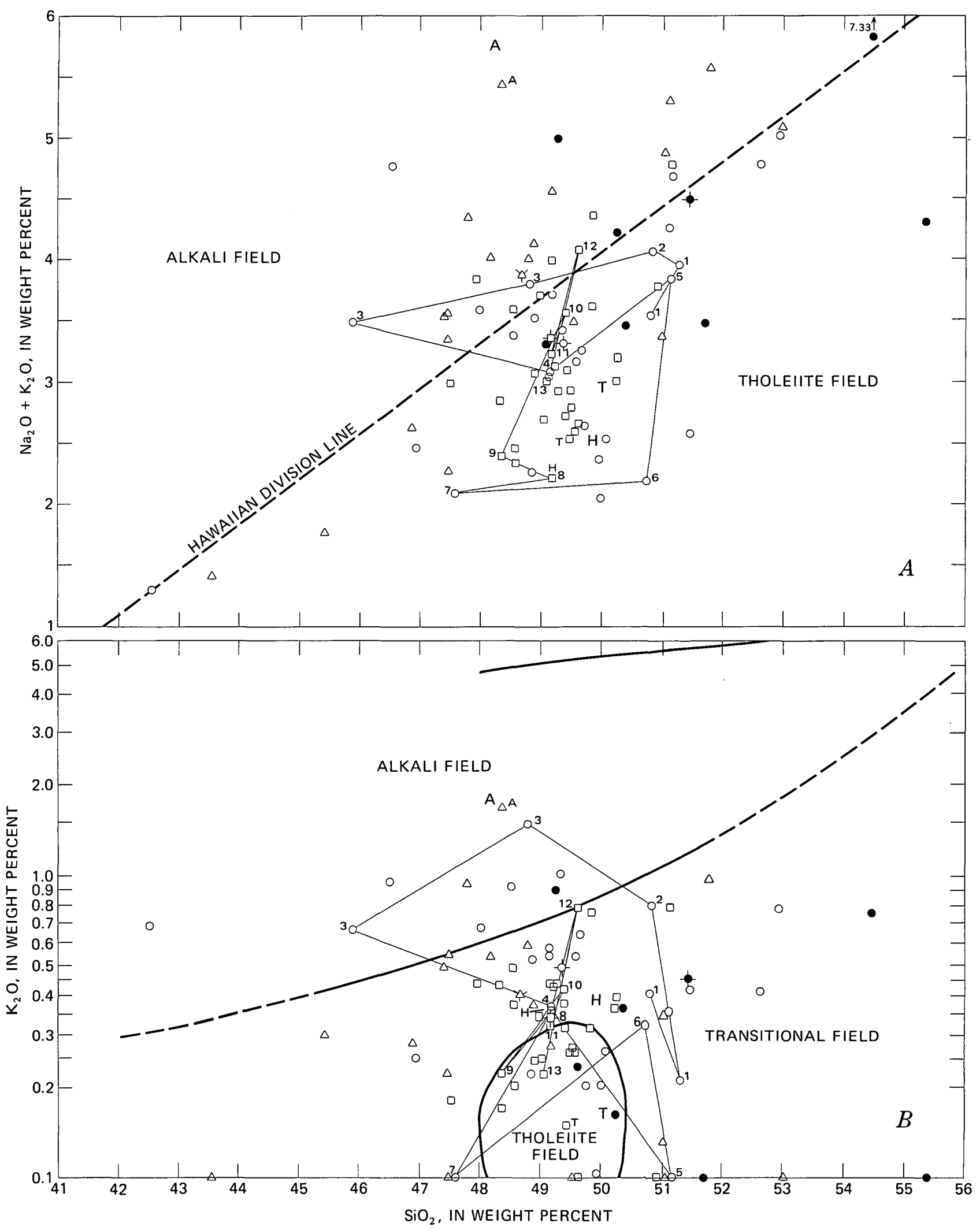

Figure 2.-Compositional diagrams of the basaltic rocks of the Olympic Peninsula, Wash., showing comparisons with abyssal oceanic tholeiitic basalts, alkali basalts from seamounts and islands, and Hawaiian tholeiitic basalts. A. Alkali versus silica; field boundary from Macdonald and Katsura (1964, fig. 1). B, Potash versus silica; field boundaries from Engel and others $\left(1965\right.$, fig. 3). $C$, $\mathrm{TiO}_{2}$ versus $\left(\mathrm{Fe}_{2} \mathrm{O}_{3}+\mathrm{FeO}\right) / \mathrm{MgO}$; field boundaries from Glassley (1974, fig. 6). 

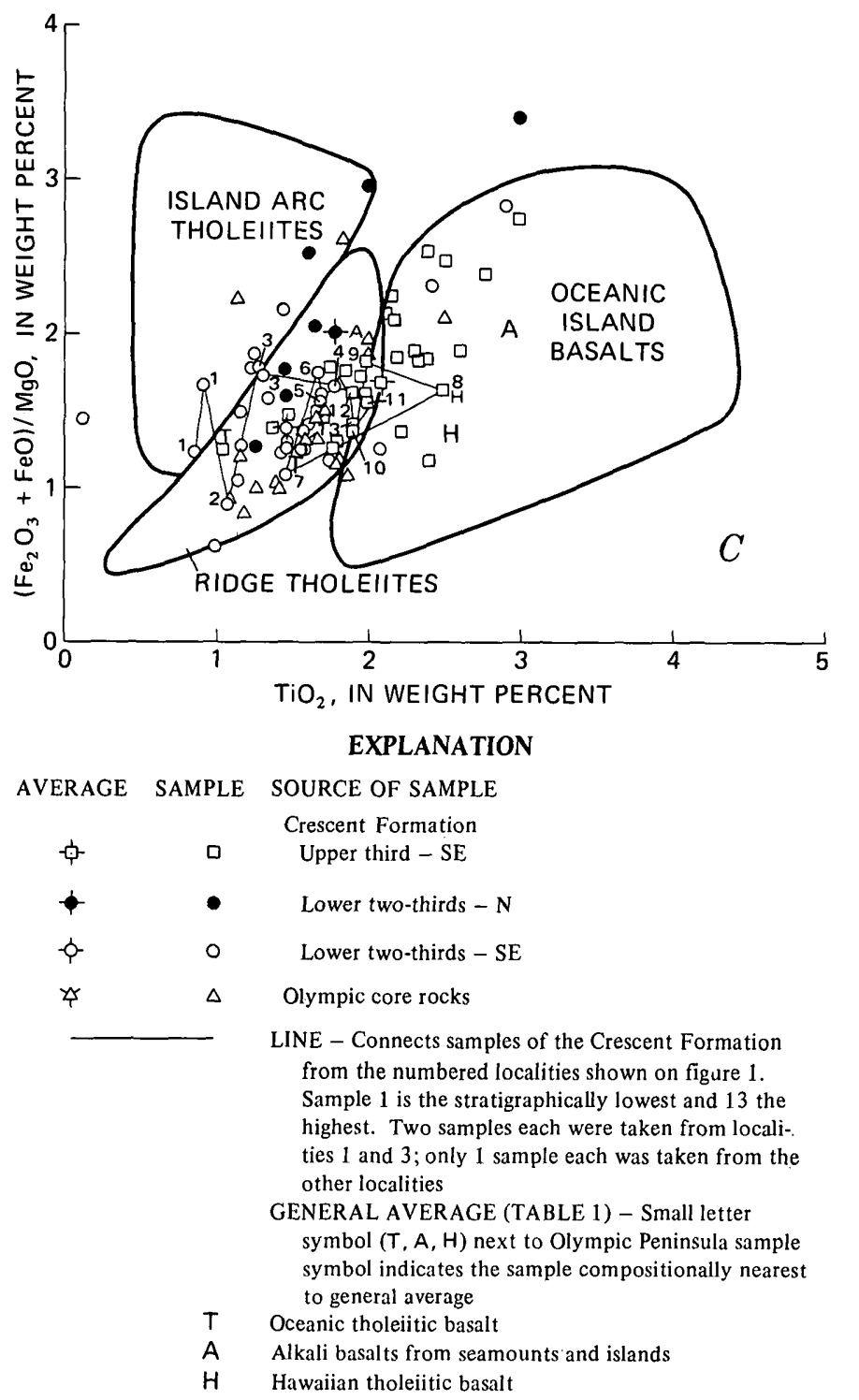

Number of samples in each fleld shown in figure 2

\begin{tabular}{|c|c|c|c|c|c|c|c|c|}
\hline \multirow[b]{2}{*}{ Rock unit } & \multicolumn{2}{|c|}{$A$} & \multicolumn{3}{|c|}{$B$} & \multicolumn{3}{|c|}{$C$} \\
\hline & $\underset{\exists}{\bar{z}}$ & 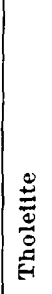 & $\underset{\mathbb{Z}}{\mathbb{Z}}$ & & 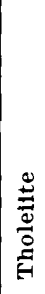 & 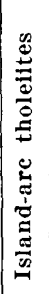 & 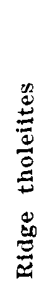 & 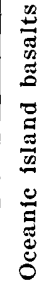 \\
\hline $\begin{array}{l}\text { Crescent Formation } \\
\text { Upper third-SE } \\
\text { Lower two-thirds-N } \\
\text { Lower two-thirds-SE } \\
\text { Olymple core rocks }\end{array}$ & $\begin{array}{r}7 \\
3 \\
6 \\
12 \\
12\end{array}$ & $\begin{array}{r}25 \\
4 \\
24 \\
7\end{array}$ & $\begin{array}{l}0 \\
1 \\
7 \\
2\end{array}$ & $\begin{array}{r}19 \\
4 \\
18 \\
15\end{array}$ & $\begin{array}{r}13 \\
2 \\
5 \\
2\end{array}$ & $\begin{array}{l}0 \\
2 \\
6 \\
2\end{array}$ & $\begin{array}{l}17 \\
4 \\
20 \\
15\end{array}$ & $\begin{array}{r}15 \\
0 \\
3 \\
2\end{array}$ \\
\hline
\end{tabular}

downward stratigraphically into those that lie beneath the basalts. This relationship is about as depicted earlier (Snavely and Wagner, 1963, fig. 2), except that the basalts are much thicker and the centers of submarine and terrestrial volcanism (seamounts and islands) that are free of nonvolcanic sediments are much less extensive. The outcrops of the two volcanic sections that interfinger with the turbidites and shales are each about $100 \mathrm{~km}$ long in the curving pattern of the peripheral rocks.

The two centers of volcanic accumulation suggest two nearly adjacent groups of volcanic seamounts, such as those that include the Cobb and Bear Seamounts off the Washington-Oregon coast (McManus, 1964, p. 67, 69, 70-71), except for three features: (1) The southeastern of the two accumulations, at least, is much thicker, than the bathymetric relief of the Cobb and Bear Seamounts, as well as of other well-known seamounts (Hamilton, 1956), (2) they interfinger laterally into the marine sedimentary rocks and hence had no bathymetric profiles, and (3) they are underlain by the turbidites and shales of the bottom of the Crescent Formation, rather than by oceanic crust. Though the thickness of the volcanic accumulations in the Olympic Peninsula may exceed the bathymetric relief of known seamounts, it possibly does not exceed the combined thickness of seamount basalts and the basalts continuous downward beneath the seamounts.

The lower $10 \mathrm{~km}$ of the southeastern volcanic section contains deep-water marine tholeiite, characterized by pillow and massive basalts with interbeds of red limestone (Garrison, 1973) holding death assemblages of early(?) to middle Eocene planktonic Foraminifera (Cady, Sorensen, and MacLeod, 1972; Cady, Tabor, and others, 1972; Rau, 1964, p. G3). This tholeiite grades upward into shallow-water marine and locally terrestrial tholeiite that comprises the upper 5 $\mathrm{km}$. The gradation, through a thickness of 500-1,000 m, is marked by a change from interbedded pillow and massive basalts, beneath, to massive basalts with closely spaced random joints, above. The upper tholeiite, characterized by the random joints, and, especially near the top, by columnar joints and scoria, contains interbeds of gray limestone with middle Eocene benthonic Foraminifera (Cady, Sorensen, and MacLeod, 1972; Cady, Tabor, and others, 1972; Rau, 1964, p. 63). The random joints appear to be cooling fractures in the thick-bedded massive basalts, inasmuch as up-section the fractures become oriented normal to the thinner upper beds of the upper tholeiite and form typical columnar joints.

The author finds neither evidence that these fractures are of tectonic origin (compare with Glassley, 1974, p. 786), nor compositional differences between the upper and lower tholeiites (p. 791-792) that are great enough to suggest anything more than simple upward lithic gradation (figs. 2-4) to rocks higher in $\mathrm{K}_{2} \mathrm{O}$ and $\mathrm{TiO}_{2}$ content. This is made especially clear 
by the fairly random compositional distribution of 15 samples collected from 13 localities in a west-east section across the eastward-topping Crescent volcanic rocks of the eastern Olympic Peninsula northwest of Brinnon (fig. 1) ; 9 of the 15 are from the lower twothirds of the Crescent basalt and the remainder from the upper third (connected by the fine lines in fig. 2).

The northern volcanic section contains chiefly deepwater marine tholeiite, but includes some shallowwater deposits near the top (Rau, 1964, p. G14).

Succeeding the Crescent Formation are middle Eocene to middle Miocene (Rau, 1964, p. G4-G6, G13; 1967 , p. 14, 17-20, 23-28), chiefly clastic, marine sedimentary rocks (Brown and others, 1960; Gower, 1960; Snavely and others, 1958 , p. 12). Interbedded with some of them are andesitic flows, tuffs, and breccias that suggest the western limits of the beginnings of Cascade volcanism (Tabor, R. W., written commun., 1972) and bespeak the end of extrusion of oceanic tholeiites. Late Eocene and late Oligocene-Miocene unconformities occur in the sedimentary section at least at basin margins (W. O. Addicott, written commun., 1971 ; P. D. Snavely, Jr. and N. S. MacLeod, written communs., 1971, 1974). The sedimentary rocks are unconformably overlapped on the south and west flanks of the peninsula (fig. 1) by upper Miocene(?) and Pliocene, chiefly shallow-water marine, sandstone and conglomerate (Rau, 1967, p. 34-38, 1973, p. 12-13; Weaver, 1937, p. 195).

The horseshoe pattern of the Crescent Formation suggests a complex dome that may have been produced by oroclinal folding. C. S. Grommé collected oriented drill-core samples from 45 localities in the Crescent volcanic rocks for study of remanent magnetism, but they failed to prove or disprove such folding, apparently because the remanent magnetization had been destroyed by metamorphism. Grommé (oral commun. 1974) reports that magnetic inclination to bedding, and hence the declination, proved random at each of these localities. Doming is well expressed only on the northeast side of the peninsula. No clear domal structure shows between the north and south sides of the "horseshoe," where stratigraphic units are less distinctive than in the Crescent Formation.

\section{CORE ROCKS}

Inside the Olympic "horseshoe" are the core rocks, mapped chiefly by R. W. Tabor. These are, in the main, slightly metamorphosed turbidites and shales-tens of thousands of metres thick-that range in age from possible Paleocene to middle Miocene (Cady, Sorensen, and McLeod, 1972; Cady, Tabor, and others, 1972, Rau,
1973, p. 5-6; Stewart, 1971, 1974; Tallyn, 1972). Interbedded and in fault contact with the sedimentary rocks are mafic volcanic rocks of Eocene age (Cady, Tabor, and others, 1972) and of essentially the same composition (table 1) as those of the Crescent Formation, but mostly less than $2 \mathrm{~km}$ thick, and commonly only a few hundred metres thick. The outer, most abundant volcanic rocks in the core are roughly concentric with the horseshoe pattern of the outlying Crescent basalts (fig. 1).

The core volcanic rocks and the interbedded turbidites and shales, which include broken formations (Tabor and others, 1970; see also Hsü, 1968, p. 10651066), from arcuate rock belts or packets bounded by fault zones. The outer fault zones, like the outer volcanic rocks of the core, conform to the horseshoe pattern, but inner faults and rock units trend northwest and are either sharply bent or truncated by shear zones along the south side of the horseshoe (fig. 1). The Hurricane Ridge fault, the outermost fault, in the north, east, and south flanks of the Olympic Mountains (Tabor and others, 1972), separates the Crescent volcanic rocks and conformably underlying sedimentary rocks (Cady, Sorensen, and MacLeod, 1972; Cady, Tabor, and others, 1972; Tabor and others, 1970) from the arcuate, faulted and sheared units of the core. This fault is commonly expressed as a nearly vertical slaty shear zone as much as $1 \mathrm{~km}$ wide, bordered on the core side by turbidites containing conspicuous detrital muscovite. Northwest of the Olympic Mountains, the Hurricane Ridge fault perhaps bifurcates to join both the Calawah fault (Gower, 1960), which immediately adjoins highly deformed core rocks to the south, and a well-defined thrust fault that dips gently northeast beneath the Crescent volcanic rocks (P. D. Snavely, Jr., and N. S. MacLeod, oral commun., 1972).

\section{STRUCTURAL HISTORY}

Two principal structural episodes can be inferred from metamorphic events radiometrically dated at 29 m.y. ago in the late Oligocene and 17 m.y. ago in the middle Miocene (Tabor, 1972; Harland others, 1964) as well as from paleontologic and structural evidence. Unconformable overlaps with little angular discordance have been recognized at the basin margins, where they reflect minor orogenic fluctuations (P. D. Snavely, Jr., and N. S. MacLeod, oral and written communs., 1973.)

Low-angle thrust faulting in the late Eocene to late Miocene was succeeded by late Miocene complex doming. By the early to middle Miocene, the rocks now exposed in the core of the Olympic Mountains, and of the same age as and younger than the Crescent Forma- 
tion, had been underthrust eastward beneath the Crescent. This thrusting produced imbricate shear zones, broken formations, and in some places melange, in the core rocks. Then, in the middle or late Miocene, or both, the bedding, faults, and shear zones in and adjoining the core terrane (most conspicuously the bedding in the Crescent and conformably overlying formations of the peripheral terrane) were warped into a dome or an orocline convex to the east.

The section in the Olympic core rocks has possibly been thickened by tectonic piling during underthrusting (N. S. MacLeod, oral commun., 1973; P. D. Snavely, Jr., written commun., 1974) piling especially of the already thick accumulation of sedimentary rocks less dense than the mafic volcanic rocks. The relative buoyancy of the subducted sedimentary rocks may also have contributed to the subsequent doming of the Olympic Mountains, with or without oroclinal folding.

\section{PROVENANCE AND PRETECTONIC RESTORATION}

The source area of detritus, as well as the depositional sites of the sedimentary and volcanic rocks of the Olympic Peninsula, must be inferred mainly from the type of clastic material. The turbidites and related sedimentary rocks of both the core and the periphery of the peninsula contain clasts eroded from the Mesozoic and perhaps Paleozoic continental terranes north of the Strait of Juan de Fuca (Ansfield, 1972; Stewart, 1970, p. 37) and east of Puget Sound. Similarly the Crescent basaltic volcanic rocks contain clasts, both in mudflow breccias and in lavas, that are believed to have been eroded from the earliest Tertiary and older terranes east of Puget Sound. These clasts, found about. $10 \mathrm{~km}$ above the base of the volcanic rocks in the eastern Olympic Mountains, are boulders of hornblendebiotite quartz diorite some as much as $3 \mathrm{~m}$ in diameter. The petrographic features and radiometric age $(65 \pm$ m.y.) are identical with those of hornblende-biotite quartz diorite at the borders of plutons in the Cascade Range to the east (F.W. Cater, oral commun., 1966; see also Cater and Crowder, 1967; Cater and Wright, 1967).

The presence of clasts of continental origin in the Eocene Crescent volcanic rocks suggests proximity to the North American continent at the time of extrusion, about 50-55 m.y. ago. At that time the continental margin was perhaps $1,300 \mathrm{~km}$ east of the Juan de Fuca Ridge or about $900 \mathrm{~km}$ east of its present position, if the Juan de Fuca and North American plates converged at a rate of about $6 \mathrm{~cm}$ per year or $60 \mathrm{~km}$ in a million years (Phillips, 1967; Vine, 1966, p. 14101413). Thus, the lower Eocene to lower Miocene section of the Olympic Peninsula, successively sedimen- tary, volcanic, and sedimentary, was deposited upon the oceanic crust and immediately became involved in subduction of the Juan de Fuca plate, well east of the crest of the Juan de Fuca ridge. This subduction accounted for the eastward underthrusting of the Olympic core rocks, already discussed, that preceded late Miocene-to-Pliocene doming or oroclinal folding, or both. It also emphasizes that the volcanic rocks, though compositionally somewhat like the oceanic ridge tholeiites, did not emerge at an active ridge crest. Instead, they were extruded upward through older volcanic rocks of the oceanic crust on the eastern flank of the ridge, as well as through an active subduction zone and through the continent-derived sedimentary rocks upon which they lie (fig. 3 ).

Before the underthrusting, the east-west span of the section of lower Eocene to lower Miocene that is included in the peripheral and core rocks of the Olympic Peninsula was probably much more (fig. 3 ) than the present 120 -km span across the peninsula (fig. 1 ) ; perhaps it was $150-200 \mathrm{~km}$. This conclusion has been reached partly because even the outermost (easternmost) volcanic rocks in the core are much thinner than those of the large volcanic centers of accumulation on the northern and southeastern peripheries of the peninsula (fig. 1); the core volcanic rocks are likely oncedistal connections of the larger center.

The core volcanic rocks may be distal western parts of the southeastern volcanic center, as suggested by the restored section (fig. 3), which shows the prethrusting distribution of the volcanic rocks. If so, the core rocks now close to the southeastern center are perhaps 50 $\mathrm{km}$ east of their original position with respect to this center. Alternatively, the core volcanic rocks, most abundant in the eastern core, may be distal southern parts of the northern volcanic center (not suggested by fig. 3). If so, they could still be $50 \mathrm{~km}$ east of their original position-southeast instead of south of the northern center. And, if the northern peripheral rocks were displaced by . oroclinal folding following underthrusting, at least the northern parts of the core volcanic rocks could have once been western distal parts of the northern peripheral volcanic center, much as proposed for the southeastern center.

The $15 \mathrm{~km}$ of Crescent basaltic rocks, which overlie $2 \mathrm{~km}$ or more of turbidite and shale and nearly fill the eastern end of the restored section, probably give way westward, with thinning of both volcanic rocks and interbedded sediments, to $5-10 \mathrm{~km}$ of turbidites and shales with which distal parts of the basalt are interbedded (fig. 3). These distal parts, as much as $2 \mathrm{~km}$ thick in the section in the eastern core of the Olympic Mountains, thin westward and disappear. 

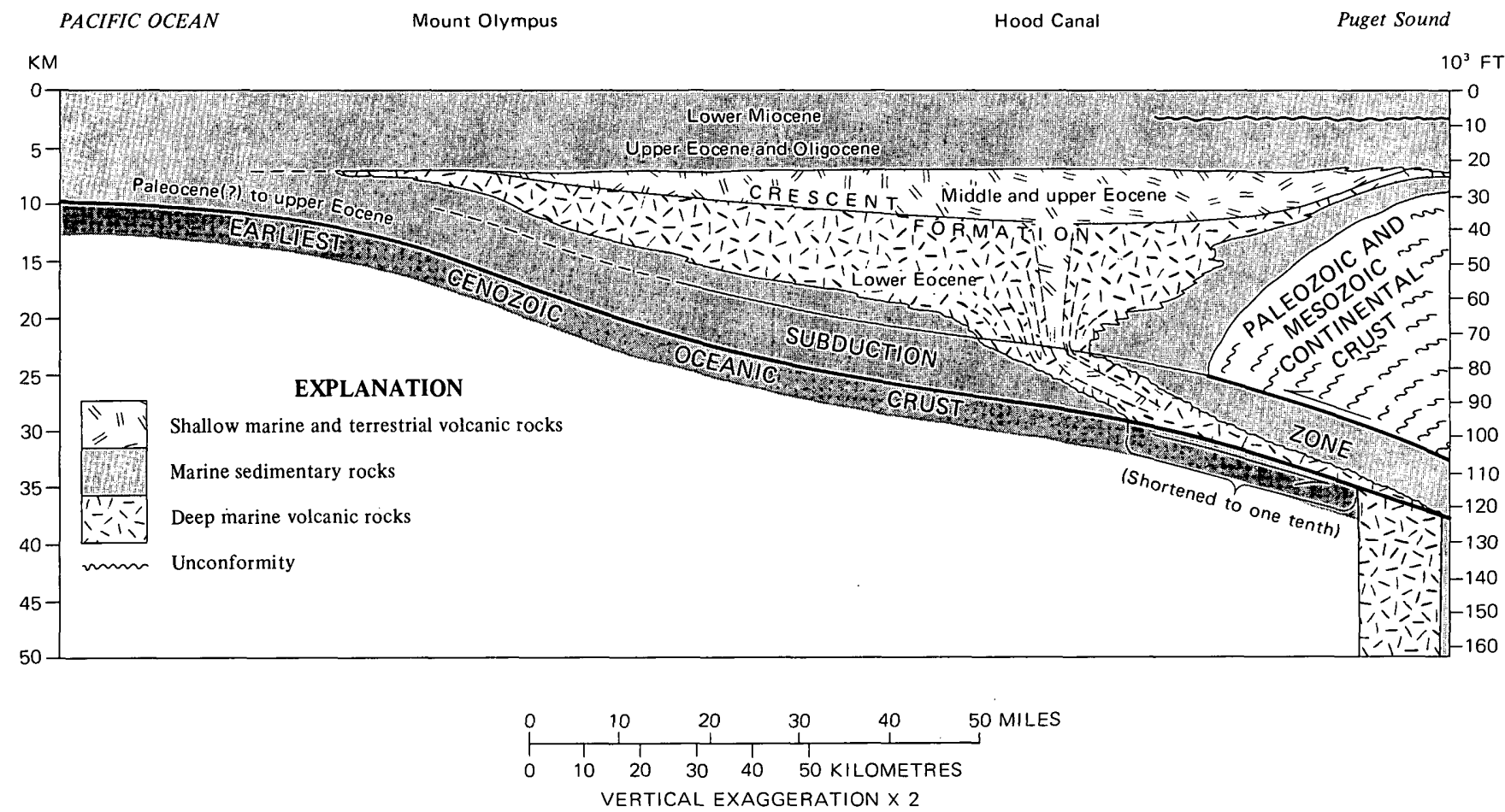

Frgure 3.-Diagrammatic restored section across the Olympic Peninsula, before late Eocene-early Miocene thrusting, showing the lower Tertiary basaltic volcanic rocks, and the clastic sedimentary rocks with which they were interbedded before thrusting occurred.

A restored section within and southward from the Olympic Peninsula appears to thin, inasmuch as comparable rocks of the same age in coastal Oregon have a total exposed thickness of less than $5 \mathrm{~km}$ (Snavely and Wagner, 1964, p. 7, fig. 3). But perhaps the difference is not great, because seismic studies suggest that the mafic volcanic rocks in Oregon are $10 \mathrm{~km}$ thick (Snavely and others, 1968, p. 456). Only the lower $1.5 \mathrm{~km}$ of the section exposed in Oregon is mafic volcanic, as compared with the $15 \mathrm{~km}$ in the thickest part of the fully exposed Crescent Formation. The sedimentary rocks probably thin north of the Olympic Peninsula toward Vancouver Island also, but the rate of thinning of both the sedimentary rocks and underlying volcanic rocks cannot be determined, because uplift was followed by erosion in that direction (fig. 1; see also Clapp, 1917, p. 277-279), and because much of the section lies beneath the Strait of Juan de Fuca.

Eastward thinning is probably abrupt against the continental terrane (fig. 3), judging from the great size of the boulders believed to be from this terrane that are incorporated in the section. Surficial deposits and the waters of Puget Sound hide the critical relationships (fig..1); especially those of the volcanic rocks to the older continental terrane. South of the sound and southeast of the Olympic Peninsula, however, pillow lavas probably of the Crescent Formation, but with base unexposed, are overlain by sedimentary rocks about $3 \mathrm{~km}$ thick-deep-water middle-to-upper Eocene siltstone succeeded in more eastern areas by upper Eocene shallow-water marine and coal-bearing nonmarine siltstone and sandstone (Snavely and others, 1958, p. 12-35). Though the base of these pillow lavas is not exposed, sedimentary rocks including quartzrich micaceous sandstone and conglomerate have been penetrated to a depth of $3,353 \mathrm{~m}$ by drilling through basalt (D. D. Hastings, oral commun., 1974) east of Puget Sound, about $30 \mathrm{~km}$ north of Seattle (Alderwood 1 well of the Standard Oil Co. of California). This basalt, whose radiometric dating places it in the early to middle Eocene, is interbedded with the sedimentary rocks at well depths of 1,709-1,722 m, 1,908$1,917 \mathrm{~m}$, and $1,981-2,149 \mathrm{~m}$.

\section{CONCLUSIONS}

The Olympic Peninsula appears to be the site of at least one and probably two centers of early to middle Eocene mafic marine volcanism, within the Juan de 
Fuca plate, that perhaps spread onto the nearby western margin at the North American plate when it was much farther east of the crest of the Juan de Fuca Ridge than at present. Proximity to the continental plate at the time of extrusion is indicated by apparently continent-derived inclusions in the marine lavas and by the fact that the volcanic rocks stratigraphically overlie and intertongue laterally with rocks whose sediments were likewise eroded from the continent to the east. Were it not for the incursion of these sediments the volcanic centers might have retained the bathymetric profiles of seamounts. Also, without incursion of the sediments tectonic piling and doming, caused by subduction of the less dense sedimentary rocks beneath the basalts, is less likely to have taken place. Erosion of the near-vertical eastward topping basalts in the east flank of the Olympic dome, or oroclinal fold, has exposed a complete 15-km section of possibly both abyssal and Hawaiian-type tholeiites. This section, which is accessible along rivers, in roadcuts, and on ridgetops above timber $10 \mathrm{~km}$ north to $20 \mathrm{~km}$ westnorthwest of Brinnon, provides unprecedented opportunities for both studies of rock relationships and for collection of samples of tholeiitic rocks that postdate, and apparently have transected, underlying rocks of the oceanic crust within the Juan de Fuca plate.

\section{REFERENCES CITED}

Ansfield, V. J., 1972, Eocene submarine cone-fan deposits and their significance, northern Olympic Peninsula, Washington: Geol. Soc. America Abs. with Programs, v. 4, no. 7, p. 435.

Brown, R. D., Gower, H. D., and Snavely, P. D., Jr., 1960, Geology of the Port Angeles-Lake Crescent area, Clallam County, Washington: U.S. Geol. Survey Oil and Gas Inv. Map OM-203.

Cady, W. M., Sorensen, M. L., and MacLeod, N. S., 1972, Geologic map of The Brothers quadrangle, Jefferson, Mason, and Kitsap Counties, Washington, U.S. Geol. Survey Geol. Quad. Map GQ-969.

Cady, W. M., Tabor, R. W., MacLeod, N. S., and Sorensen, M. L., 1972, Geologic map of the Tyler Peak quadrangle. Clallam and Jefferson Counties, Washington: U.S. Geol. Survey Geol. Quad. Map GQ-970.

Cater, W. F., and Crowder, D. F., 1967, Geologic map of the Holden quadrangle, Snohomish and Chelan Counties, Washington: U.S. Geol. Survey Geol. Quad. Map GQ-646.

Cater, W. F., and Wright, T. L., 1967, Geologic map of the Lucerne quadrangle, Chelan County, Washington: U.S. Geol. Survey Geol. Quad. Map GQ-647.

Clapp, C. H., 1967, Sooke and Duncan map areas, Vancouver Island: Canada Geol. Survey Mem. 96, 445 p.

Engel, A. E. J., Engel, C. G., and Havens, R. G., 1965, Chemical characteristics of oceanic basalts and the upper mantle: Geol. Soc. America Bull., v. 76, no. 7, p. 719-734.

Garrison, R. E., 1973, Space-time relations of pelagic limestones and volcanic rocks, Olympic Peninsula, Washington: Geol. Soc. America Bull., v. 84, no. 2, p. 583-593.
Glassley, William, 1974, Geochemistry and tectonics of the Crescent volcanic rocks, Olympic Peninsula, Washington: Geol. Soc. America Bull., v. 85, no. 5, p. 785-794.

Gower, H. D., 1960, Geologic map of the Pysht quadrangle, Washington: U.S. Geol. Survey Geol. Quad. Map GQ-129.

Hamilton, E. L., 1956, Sunken islands of the Mid-Pacific Mountains: Geol. Soc. America Mem. 64, 97 p.

Harland, W. B., Smith, A. G., and Wilcox, B., eds., 1964, The Phanerozoic time scale: Geol. Soc. London Quart. Jour., v. $120,458 \mathrm{p}$.

Hsii, K. J., 1968, Principles of melanges and their bearing on the Franciscan-Knoxville paradox: Geol. Soc. America Bull., v. 79, no. 8, p. 1063-1074.

Macdonald, G. A., and Katsura, Takaski, 1964, Chemical composition of Hawaiian lavas: Jour. Petrology, v. 5, no. 1, p. 82-133.

McManus, D. A., 1964, Major bathymetric features near the coast of Oregon, Washington, and Vancouver Island: Northwest Science, v. 38, no. 3, p. 65-82.

Miller, M. S., 1967, The bedrock geology of the southeast quarter of Mount Steel quadrangle, Washington: Seattle, Washington Univ., M.S. thesis, 78 p.

Phillips, J. D., 1967, Magnetic anomalies over the Mid-Atlantic Ridge near $27^{\circ} \mathrm{N}$ : Science, v. 157 , p. $920-923$.

Rau, W. W., 1964, Foraminifera from the northern Olympic Peninsula, Washington: U.S. Geol. Survey Prof. Paper 374G, p. G1-G33.

1967, Geology of the Wynoochee Valley quadrangle, Grays Harbor County, Washington: Washington Div. Mines and Geology Bull. 56, 51 p.

1973, Geology of the Washington coast between Point Grenville and the Hoh River: Washington State Dept. Natural Resources Bull. 66, 58 p.

Snavely, P. D., Jr., Brown, R. D., Jr., Roberts, A. E., and Rau, W. W., 1958, Geology and coal resources of the CentraliaChehalis district, Washington: U.S. Geol. Survey Bull. 1053, $159 \mathrm{p}$.

Snavely, P. D., Jr., MacLeod, N. S., and Wagner, H. C., 1968, Tholeiitic and alkalic basalts of the Eocene Siletz River Volcanics, Oregon Coast Range: Am. Jour. Sci., v. 226, no. 6, p. 454-481.

Snavely, P. D., Jr., and Wagner, H. C., 1963, Tertiary geologic history of western Washington: Washington Div. Mines and Geol. Rept. Inv. 22, 25 p.

__ 1964, Geologic sketch of northwestern Oregon: U.S. Geol. Survey Bull. 1181-M, 17 p.

Stewart, R. J., 1970, Petrology, metamorphism and structural relations of graywackes in the western Olympic Peninsula, Washington: Stanford, Stanford, Univ., Ph. D. dissert., $129 \mathrm{p}$.

1971, Structural framework of the western Olympic Peninsula, Washington: Geol. Soc. America Abs. with Programs, v. 3, no. 2, p. 201.

1974, Zeolite facies metamorphism of sandstone in the western Olympic Peninsula, Washington: Geol. Soc. America Bull., v. 85, no. 7, p. 1139-1142.

Tabor, R. W., 1972, Age of the Olympic metamorphism, Washington-K-Ar dating of low-grade metamorphic rocks: Geol. Soc. America Bull., v. 83, no. 6, p. 1805-1816. 
Tabor, R. W., Cady, W. M., and Yeats, R. S., 1970, Broken formations and thrust faulting in the northeastern Olympic: Mountains, Washington: Geol. Soc. America Abs. with Programs, v. 2, no. 2, p. 152.

Tabor, R. W., Yeats, R. S., and Sorensen, M. L., 1972, Geologic map of the Mount Angeles quadrangle, Clallam and Jefferson Counties, Washington: U.S. Geol. Survey Geol. Map GQ-958.

Tallyn, R. B., 1972, Petrology and stratigraphy of graywackes in the northwestern Olympic Mountains, Washington: Seattle, Washington Univ., M.S. thesis, $36 \mathrm{p}$.

U.S. Geological Survey, 1963, Geological Survey research 1963 : U.S. Geol. Survey Prof. Paper 475-A, 300 p.

1964, Geological Survey research 1964: U.S. Geol. Survey Prof. Paper 501-A, 367 p.

1965, Geological Survey research 1965 : U.S. Geol. Survey Prof. Paper 525-A, 376 p. [1966].
1966, Geological Survey research 1966 : U.S. Geol. Survey Prof. Paper 550-A, 385 p. [1967].

1969, Geological Survey research 1969 : U.S. Geol. Survey Prof. Paper 650-A, 425 p. [1970].

1970, Geological Survey research 1970 : U.S: Geol. Survey Prof. Paper 700-A, 426 p. [1971].

1971, Geological Survey research 1971: U.S. Geol. Survey Prof. Paper 750-A, 418 p. [1972].

1972, Geological Survey research 1972: U.S. Geol. Survey Prof. Paper $800-A, .320$ p.. [1973].

1973, Geological Survey research 1973 : U.S. Geol. Survey Prof. Paper 850, 366 p: [1974].

Vine, F. J., 1966, Spreading of the ocean floor-new evidence: Science, v. 154, no. 3755 , p. 1405-1415.

Weaver, C. E., 1937, Tertiary stratigraphy of western Washington and northwestern Oregon: Seattle, Washington Univ. Pub. Geology, v. 4, 266 p. 


\title{
TECTONICS OF THE WESTERN VALLEY AND RIDGE FOLDBELT, PENDLETON COUNTY, WEST VIRGINIA-A SUMMARY REPORT
}

\author{
By WILLIAM J. PERRY, Jr., Reston, Va.
}

\begin{abstract}
A belt of high anticlines, the Nittany anticlinorium, occupies the western Valley and Ridge foldbelt in the central Appalachians. It extends southwestward from the Nittany arch of central Pennsylvania into the Virginias. An investigation of the tectonics of this anticlinorium in Pendleton County, W. Va., rules out active basement involvement in the deformation of the area. Cross-sectional models consistent with the accumulated data show that Middle Cambrian through Middle Ordovician carbonate rocks are tectonically stacked, shingle-fashion, from southeast to northwest below predominantly folded younger strata that have undergone less lateral shortening. Differential shortening in this area is of the proper order to balance cover deformation in the Allegheny synclinorium to the west. Field relations suggest a long period of abnormally high fluid pressures in Lower Devonian and older strata during deformation. At this time, the area was under sufficient northwest, near-horizontal compressive stress for abundant quartz deformation lamellae to form. Gravity sliding is ruled out as the deforming mechanism for this part of the Appalachian foldbelt. No significant tectonism appears to have occurred prior to Pennsylvanian time in this area.
\end{abstract}

Rapid progress has been made over the last several years in the resolution of Appalachian foreland tectonics (Gwinn, 1970; Harris, 1970; Miller, 1973, Root, 1973a and b; Jacobeen and Kanes, 1974). This brief report summarizes additional related work completed during this period (Perry, 1971). The work had been undertaken to define the structural development of the Nittany anticlinorium (fig. 1) and included geologic mapping and related field studies, interpretation of more than 30 miles $(48 \mathrm{~km})$ of seismic-reflection profiles, and dynamic analysis of quartz, completed during 1967 through 1970. A study of mesoscopic deformation in the area is underway.

Acknowledgments.-The initial work was supported in part by Yale University, the West Virginia Geological and Economic Survey, and the Society of Sigma Xi. Encouragement and helpful suggestions throughout the course of this work were provided by John Rodgers, Karl Waage, and R. L. Armstrong of Yale University. Additional encouragement or suggestions were provided by N. L. Carter, State University of New York at Stony Brook; John Dennison, University of North Carolina, R. B. Erwin, State
Geologist of West Virginia, and D. H. Cardwell, West Virginia Geological Survey.

\section{GENERAL GEOLOGY}

The Nittany anticlinorium is a group of major anticlines in the western Valley and Ridge province of the central Appalachian orogenic belt. It extends southwestward from the Nittany arch of central Pennsylvania into the Virginias and is bounded on the west by the Allegheny Front and on the east by the Broadtop synclinorium. In the area studied (fig. 1), the sedi-

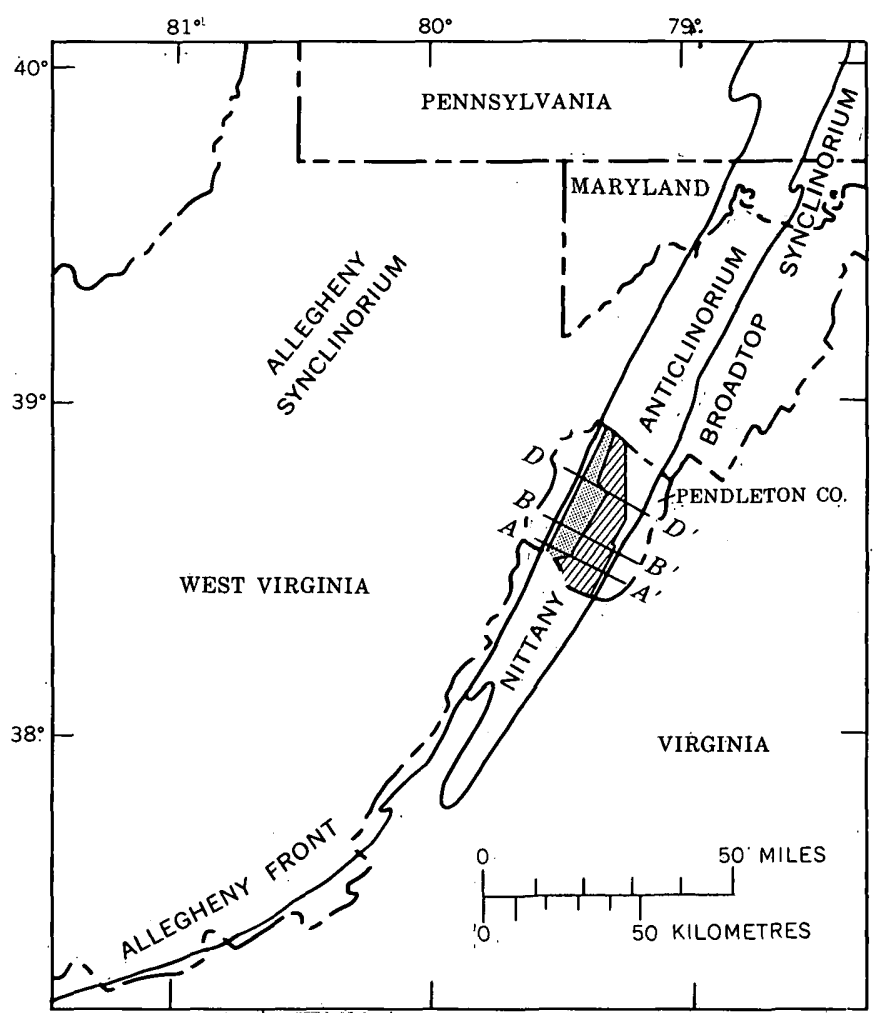

Figure 1.-Map showing the redefined southern limit of the Nittany anticlinorium, the area studied (indicated by screen and line patterns), and the location of cross-sectional models. The geology of the screened area was mapped in detail; that of the lined area was traversed in order to check previous geologic mapping (Tilton and others, 1927) to provide control for cross-sectional models (Cross sections $A-A^{\prime}$ and $B-B^{\prime}$ are discussed in Perry, 1971). 
mentary section is about $21,000 \mathrm{ft}(6,400 \mathrm{~m})$ thick and ranges in age from Cambrian to Pennsylvanian, including post-Middle Devonian beds eroded from the anticlinorium but exposed just to the west. Close examination of the stratigraphy of outcropping Middle Ordovician to Devonian beds across the anticlinorium resulted in several stratigraphic clarifications (Perry, 1972, and unpub. data, 1975). More than $9,000 \mathrm{ft}$ $(2,740 \mathrm{~m})$ of section was measured, and nearly 7,500 $\mathrm{ft}(2,290 \mathrm{~m})$ was described. Neither thickness of competent units nor facies appear to be related to structural position. Therefore, fold growth in the area is postMiddle Devonian. No pebbles or cobbles of recognizable older formations in Devonian through Lower Pennsylvanian strata were noted by Tilton, Prouty, and Price (1927), Dennison and Naegele (1963), and the writer, indicating no major structural relief formed on or near the Nittany anticlinorium in the study area during this time by growing folds or advancing thrust sheets.

The western margin of the anticlinorium contains the highest fold in this part of West Virginia, the Wills Mountain anticline, which has about 13,000 ft $(3,960 \mathrm{~m})$ of structural relief. This fold is not present below a major thrust fault encountered at a depth of $10,021 \mathrm{ft}(3,054 \mathrm{~m})$ below ground level in the United Fuel Gas Co., Sponaugle 1 well in the south-central part of Pendleton County (Perry, 1964, 1971). In the central part of the anticlinorium, the northeastplunging Jack Mountain anticlines extend into the area from Highland County, Va., just to the southwest. These give way along strike to the northeast to relatively low folds followed northeastward by the Middle Mountain syncline. Along the eastern margin of the anticlinorium, en echelon relatively narrow folds have formed in Silurian and Lower Devonian strata.

\section{GEOLOGIC MAPPING AND MEGASCOPIC STRUCTURAL FEATURES}

A generalized geologic map of the central and northern area that was mapped in detail (fig. 2) shows the Germany Valley culmination, which exposes the oldest beds in the area. No east-dipping reverse faults of major $(>300 \mathrm{~m}$ ) displacement crop out along the northwest limb of the anticline or the adjacent Allegheny Front. The Wills Mountain fault (Perry, 1964), which has more than $2 \mathrm{mi} .(3.2 \mathrm{~km})$ estimated displacement and was encountered in the Sponaugle well, does not surface along the west limb of the anticlinorium. Downplunge northeast from the Germany
Valley culmination, the Wills Mountain anticline becomes a complex fold, the Wills Mountain anticlinorium of Dennison, Travis, and Ferguson (1966), as secondary folds appear at the Upper Ordovician to Lower Devonian structural level. I submit that this area shows evidence of the same structural disharmony between Silurian and Devonian rocks and the Cambrian and Ordovician carbonate sequence that can be recognized elsewhere in the region by comparing the surface geology and seismic data.

Longitudinal faults at low angles to bedding are present on both limbs of the Wills Mountain anticline-in the Judy Gap area and northeast of Mouth of Seneca on the northwest limb and about 2 miles southeast of Riverton on the southeast limb (fig. 2). The downthrown side of these faults is closer to the axial trace of the Wills Mountain anticline than the upthrown side. These have been termed concentric faults by Gwinn (1964), who showed that their geometry tends to resolve the space problem of concentric folding. These faults also tend to thicken the fold limbs tectonically. Dynamic analysis of quartz from the Tuscarora Sandstone on both limbs of the anticline shows that the principal compressive stress during intragranular deformation was nearly parallel to bedding and the dip direction of the fold limbs. This is consistent with the shear sense of the concentric faults.

I have tentatively concluded that a sequence of faulting and folding can be established in the area. Minor folds with subhorizontal axial planes and associated longitudinal faults at low angles to dip of bedding (with shear sense opposite that of the concentric faults) on the nearly vertical northwest limb of the Wills Mountain anticline appear to predate the growth of this anticline. These faults probably originated as southeast-dipping thrust faults when the beds were nearly horizontal. Concentric (thrust) faults formed early, probably during the early stages of folding. On the northwest limb, these thrust faults were rotated about the fold axis, in some places through the vertical position, as the fold limb rotated. Consequently, the mapped longitudinal fault at Judy Gap now dips steeply southeast with a "normal" sense of throw (fig. 3).

In the Judy Gap area, northeast-trending joints or incipient joints in Lower Devonian sandstone, which probably formed before or during early stages of folding, became the loci of shear fractures at high angles to bedding on the vertical to overturned northwest limb. Similarly oriented shear fractures in the Tuscarora Sandstone (Lower Silurian) in this area cut and displace minor longitudinal faults whose orientation and shear sense is that of the mapped concentric faults. 
EXPLANATION

DEVONIAN SYSTEM

Doh Oriskany Sandstone and Helderberg Group

SILURIAN SYSTEM

EStw目 Tonoloway and Wills Creek Formations

Smrh Mifflintown and Rose Hill Formations

St Tuscarora Sandstone

ORDOVICIAN SYSTEM

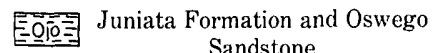

Or Reedsville Shale

Fot Trenton Group

Jost Sub-Trenton formations

---- Contact, dashed where approximate

Reverse or thrust fault, dashed wher approximate (sawteeth on upper plate)

-- Lateral fault, dashed where approximate (arrows show apparent movement direction)

U --- Normal fault, long dashed where approximate, short dashed where inferred (U, upthrown side; $D$, down thrown side)

$\uparrow-$ Anticlinal axis, dashed where approximate (arrow shows direction of plunge)

x Quarry

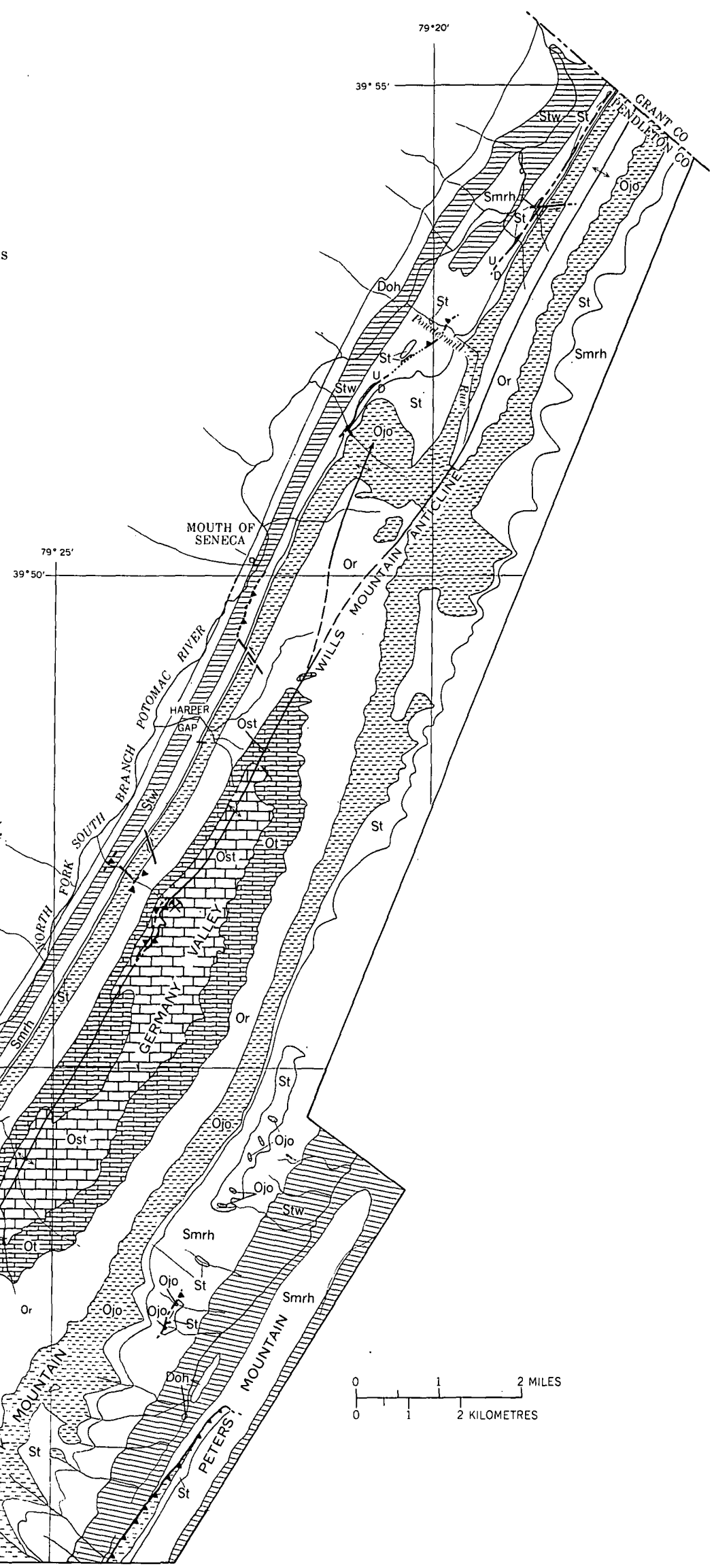

Figure 2.-Generalized geologic map of northern and central part of the Wills Mountain anticline, in Pendleton County, W. Va. 


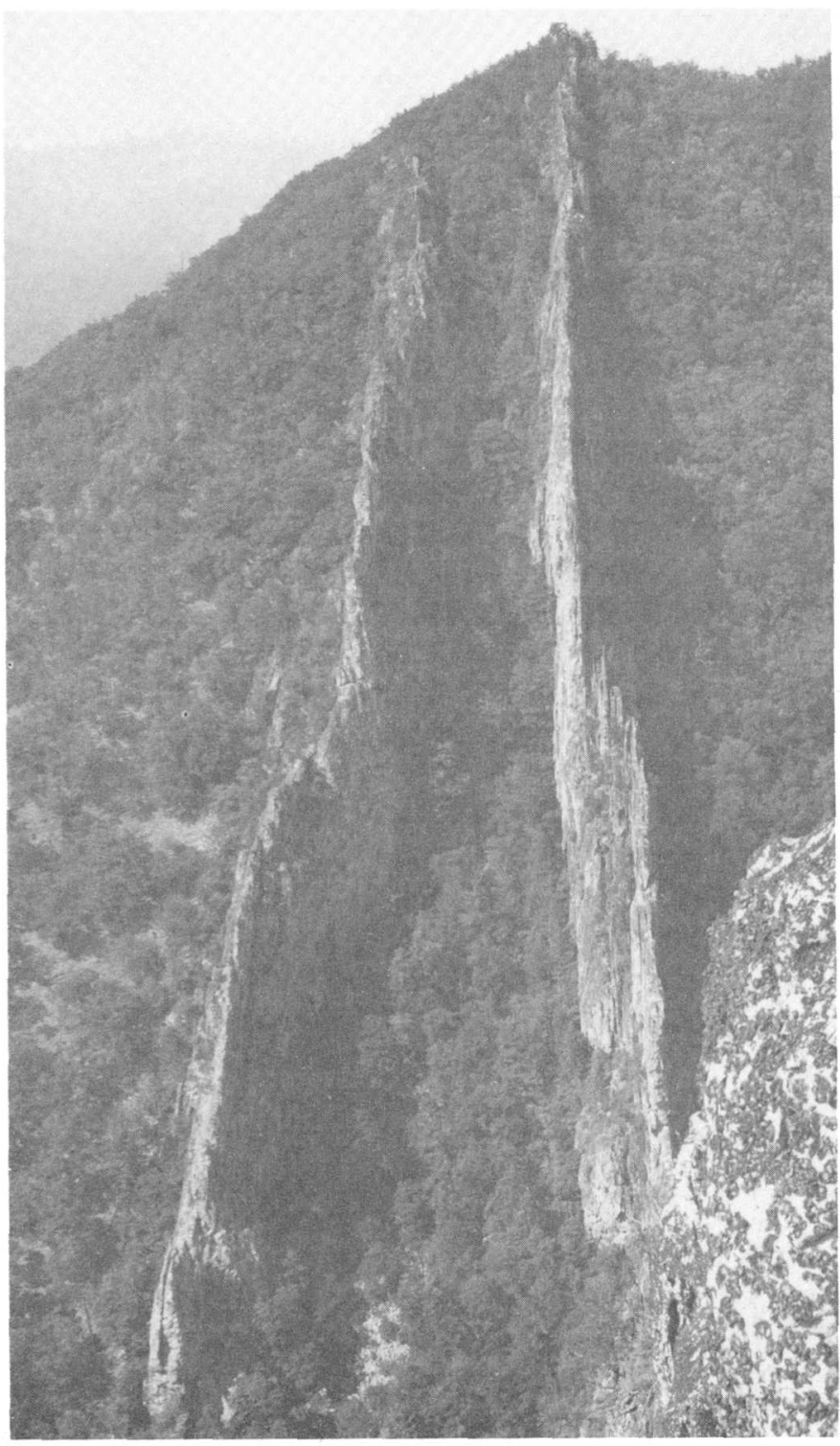

Figure 3.-Doubled outcrop belt of Tuscarora Sandstone (Lower Silurian) on the northeastern side of Nelson Gap, separated by the Judy Gap fault, which dips steeply southeast. Locality about $5,000 \mathrm{ft}(1,500 \mathrm{~m})$ southwest of Judy Gap; view northeast; side of gap about $900 \mathrm{ft}(270 \mathrm{~m})$ high.

\section{SEISMIC-REFLECTION PROFILES}

A long seismic-reflection profile across the southern part of the Nittany anticlinorium in Pendleton County (Perry, 1971, fig. 57) shows that the relatively narrow surface anticlines in the Silurian and Devonian strata at the surface are not present below the Reedsville Shale (Upper Ordovician). A group of seismic reflections and possible interformational multiples extends across the base of the profile, is inclined rather uniformly southeast, and is absent only where records are poor. The source of these acoustic events is strata of probable Early Cambrian age directly above the basement. The inclination of and traveltime to these nearbasement events must be partly attributed to structural complexity of the cover, especially where high-velocity dolostones are tectonically stacked. No unequivocal evidence of basement faulting is present, and no major faulting involving both basement and cover appears along this profile. The attitude of middle-depth events requires several thrust faults in the Cambrian and Ordovician carbonate sequence, which must join a detachment surface (décollement) in the underlying probable shaly sequence, because these faults do not displace the near-basement events. Wave-path and velocity analysis of cross-sectional models of the Wills Mountain anticline was completed, using additional seismic profiles and velocity control from the Sponaugle well. This led to the conclusion that the basement is very gently arched under the anticlinorium, the axis being east of the Wills Mountain anticline.

\section{PRINCIPAL FEATURES OF CROSS-SECTIONAL MODELS}

Three cross-sectional models were prepared across the Nittany anticlinorium, one of which is shown in figure 4. These were closely constrained by nearby seismic profiles and the Sponaugle well (Perry, 1964). Geologic mapping and additional surface traverses along the lines of section provide further constraints. These sections show three principal structural levels. The upper level, predominantly folded, is composed of Upper Ordovician, Silurian, and Lower Devonian sandstone, mudstone, shale, and limestone in relatively thin units of contrasting lithologies and apparent ductilities (based on field observations). The middle level consists of the predominantly thrust-faulted Cambrian and Ordovician carbonate sequence, chiefly massive dolostone, tectonically stacked shingle-fashion from southeast to northwest in four major thrust blocks, each approximately $7,400 \mathrm{ft}(2,250 \mathrm{~m})$ thick. The basal level consists of inferred Lower Cambrian strata which overlie a probable gneissic basement. The top of the basement surface is about 18,000-19,000 ft $(5,490-5,790 \mathrm{~m})$ below sea level, as inferred from seismic data. Each of the three levels is overlain by a relatively thick shaly sequence; the lowest shaly sequence is inferred from Great Valley stratigraphy and locally derived seismic data.

Lateral shortening is held constant in the crosssectional models from base to top of the Cambrian and Ordovician carbonate sequence and also within the upper tectonic level, a consequence of mass-conservation considerations. This would not be valid if faulting occurred during deposition of these sequences, an al- 


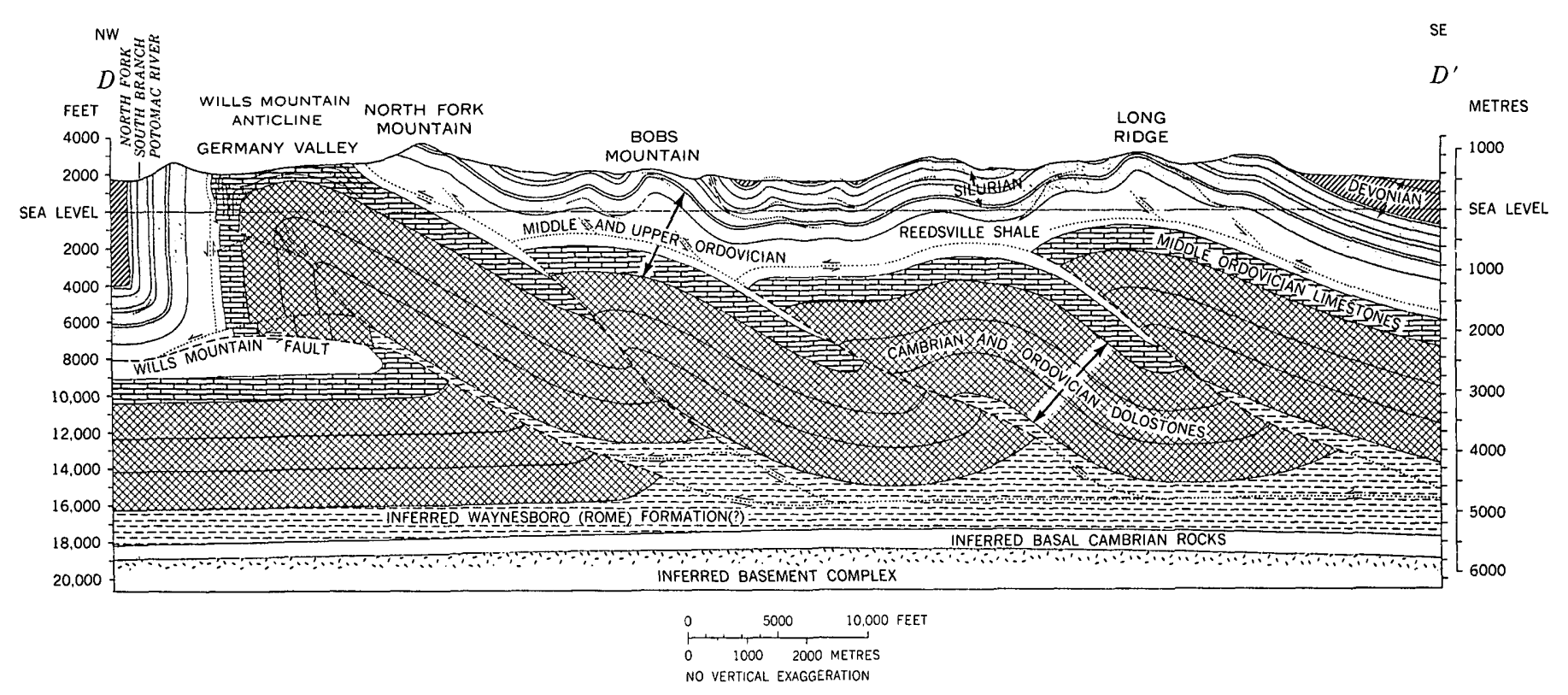

Figure 4.-Cross-sectional model $D-D^{\prime}$ across the Nittany anticlinorium. Location given in figure 1.

ternative that is unlikely in the study area. The crosssectional area of the Rome Formation and Reedsville Shale is held within bounds so that no significant mass imbalance exists between predeformational and postdeformational configurations.

\section{SHORTENING ACROSS NITTANY ANTICLINORIUM}

Tectonic shortening in the Upper Ordovician through Lower Devonian sequence in Pendleton County is $3.1 \mathrm{mi}(5 \mathrm{~km})$ on each of three cross-sectional models constructed across the entire anticlinorium, representing a shortening of 20 percent. Deformation represented by wedging and other faulting (Sites, 1973) in brittle units, penetrative deformation in shale (Nickelsen, 1966), and cleavage in mudstone and limestone, (Nickelsen, 1972) may represent an additional 10 percent shortening in these units, raising the total to about $4.1 / 2 \mathrm{mi}(7.2 \mathrm{~km})$. However, shortening in the Cambrian and Ordovician carbonate sequence is appreciably greater ( $7.6 \mathrm{mi}$ or $12.2 \mathrm{~km}$, fig. 4) and may exceed $9 \mathrm{mi}(14.4 \mathrm{~km})$, if there is an additional 10 percent shortening.

In order to conserve cross-sectional area (assuming mass-conservation during deformation) and not contradict surface, drill-hole, and seismic data, differential shortening of at least several miles must exist under the Nittany anticlinorium between the older and younger sequences and must be balanced by equal and opposite differential shortening to the southeast or northwest. In both the Broadtop synclinorium to the east (Jacobeen and Kanes, 1974) and the Allegheny synclinorium to the west (Rodgers, 1963; Gwinn,
1964), the Silurian and younger sequence has undergone greater shortening than the Cambrian and Ordovician carbonate sequence, according to the crosssectional models those anthors presented.

The shortening in the Silurian and younger sequence in the Broadtop synclinorium would appear to balance excess shortening in the Cambrian and Ordovician carbonate sequence farther east. That in the Allegheny synclinorium is of the correct order of magnitude to account for the excess shortening in the Cambrian and Ordovician carbonate sequence under the Nittany anticlinorium.

\section{INFERENCES CONCERNING CONDITIONS DURING DEFORMATION}

From the various lines of investigation, I conclude that structural development of the Nittany anticlinorium occurred as a result of lateral compression (Perry, 1971). Regional stratigraphic conditions (Colton, 1970) require that Lower Devonian and underlying beds dipped eastward to northeastward in the area at the close of the Devonian, assuming a reasonable paleoelevation for the upper surface of the Devonian clastic wedge. On the basis of published thicknesses of the upper Paleozoic rocks to the west, general dip across the region was to the southeast on the buried Lower Devonian and older beds during the late Paleozoic. Consequently, the décollement surface also dipped eastward. Proponents of gravity sliding must either reinterpret Appalachian deformation in terms of southeastward gravity gliding of cover over basement, contrary to all available evidence, or abandon this 
mechanism. As suggested independently by Root (1973b), the gravity-flow model applied by Price and Mountjoy (1970) to the structural evolution of the southern Canadian Rocky Mountains could apply also to the central Appalachians.

Dynamic analysis of quartz deformation lamellae from Tuscarora Sandstone (Lower Silurian) in the largest fold in the area indicates that the maximum principal compressive stress during intragranular flow was oriented approximately perpendicular to the axis of this (then probably incipient) fold and nearly parallel to bedding.

The presence of calcite and quartz-filled fractures (veins) on the limbs of major folds in the study area in Lower Devonian and older beds indicates that abnormal fluid pressures in the area were sufficient to fracture the beds involved or to open preexisting fractures hydraulically (Secor, 1965). Field relations indicate that abnormally high fluid pressures existed before and after mesoscopic faulting; they were evidently present for a long period during the deformation history of the area. Transition upward to normal fluid pressures in the thick blanket of Devonian shales before and during deformation may be responsible for the near absence of brittle deformation features other than joints in beds younger than Devonian in the central Appalachians of West Virginia.

\section{REFERENCES CITED}

Colton, G. W., 1970, The Appalachian basin-its depositional sequences and their geologic relationships, in Fisher, G. W., and others, eds., Studies of Appalachian geology : central and southern: New York, Interscience, p. 5-47.

Dennison, J. M., and Naegele, O. D., 1963, Structure of Devonian strata along Allegheny Front from Corriganville, Maryland, to Spruce Knob, West Virginia: West Virginia Geol. and Econ. Survey Bull. 24, 42 p.

Dennison, J. M., Travis, J. W., and Ferguson, J. H., 1966, Kittlelick thrust-A new fault in Mineral and Grant Counties, West Virginia: West Virginia Acad. Sci. Proc., v. 38, p. 177-185.

Gwinn, V. E., 1964, Thin-skinned tectonics in the Plateau and northwestern Valley and Ridge provinces of the central Appalachians: Geol. Soc. America Bull., v. 75, no. 9, p. 863900.

1970, Kinematic patterns and estimates of lateral shortening, Valley and Ridge and Great Valley provinces, central Appalachians, south-central Pennsylvania, in
Fisher, G. W., and others, eds., Studies of Appalachian geology: central and southern: New York, Interscience, p. 127-146.

Harris, L. D., 1970, Details of thin-skinned tectonics in parts of Valley and Ridge and Cumberland Plateau provinces of the southern Appalachians, in Fisher, G. W., and others, eds., Studies of Appalachian geology: central and southern: New York, Interscience, p. 161-173.

Jacobeen, Frank, Jr., and Kanes, W. H., 1974, Structure of Broadtop synclinorium and its implications for Appalachian structural style: Am. Assoc. Petroleum Geologists Bull., v. 58, no. 3, p. 362-375.

Miller, R. L., 1973, Where and why of Pine Mountain and other major fault planes, Virginia, Kentucky, and Tennessee: Am. Jour. Sci., v. 273-A, p. 353-371.

Nickelsen, R. P., 1966, Fossil distortion and penetrative rock deformation in the Appalachian Plateau, Pennsylvania: Jour. Geology, v. 74, no. 6, p. 924-931.

1972, Attributes of rock cleavage in some mudstones and limestones of the Valley and Ridge province, Pennsylvania : Pennsylvania Acad. Sci. Proc., v. 46, p. 107-112.

Perry, W. J., Jr., 1964, Geology of the Ray Sponaugle well, Pendleton County, West Virginia: Am. Assoc. Petroleum Geologists Bull., v. 48, no. 5, p. 659-669.

1971, Structural development of the Nittany anticlinorium, Pendleton County, West Virginia: New Haven, Conn., Yale Univ., Ph. D. dissert., 227 p.; West Virginia Geol. and Econ. Survey, open-file rept.

- 1972, The Trenton Group of Nittany anticlinorium, eastern West Virginia: West Virginia Geol. and Econ. Survey Circ. 13, 30 p.

Price, R. A., and Mountjoy, E. W., 1970, Geologic structure of the Canadian Rocky Mountains between Bow and Athabasca Rivers; a progress report: Geol. Assoc. Canada, Spec. Paper 6, p. 7-25.

Rodgers, John, 1963, Mechanics of Appalachian foreland folding in Pennsylvania and West Virginia : Am. Assoc. Petroleum Geologists Bull., v. 47, no. 8, p. 1527-1536.

- 1970, The tectonics of the Appalachians: New York, Interscience, $271 \mathrm{p}$.

Root, S. I., 1973a, Sequence of faulting, southern Great Valley of Pennsylvania: Am. Jour. Sci., v. 273, no. 2, p. 97-112.

$1973 \mathrm{~b}$, Structure, basin development, and tectogenesis in the Pennsylvania portion of the folded Appalachian, in De Jong, K. A., and Scholten, R., eds., Gravity and tectonies: New York, John Wiley, p. 343-360.

Secor, D. T., Jr., 1965, Role of fluid pressure in jointing: Am. Jour. Sci., v. 263 , no. 8 , p. 633-646.

Sites, R. S., 1973, Geology of the Smokehole region of West Virginia: Southeastern Geology, v. 15, no. 3, p. 153-168.

Tilton, J. L., Prouty, W. F., and Price, P. H., 1927. Pendleton County: West Virginia Geol. Survey [County repts.], 384 p., 80 pls., 2 maps. 


\title{
QUATERNARY FAULTS AT SAN DIEGO BAY, CALIFORNIA
}

\author{
By GEORGE W. MOORE and MICHAEL P. KENNEDY,' \\ Menlo Park, Calif., La Jolla, Calif.
}

Work done in cooperation with Scripps Institution of Oceanography

\begin{abstract}
Acoustic-reflection profiles of subbottom strata reveal numerous faults that cut Quaternary deposits within and directly outside of San Diego Bay. These faults, together with previously mapped onshore faults, constitute the Rose Canyon fault zone that forms the local west boundary of the Santa Ana tectonic block, which is bounded on the east by the Elsinore fault zone. The minor earthquakes that have been felt in San Diego during historic time and accurately recorded during the past $41 \mathrm{yr}$ are too infrequent to explain the observed rate of slip. The principal faulting is inferred to take place during moderate earthquakes similar to previous ones recorded along the west side of the Santa Ana block in 1933 at Long Beach, Calif., and in 1956 at San Miguel, Baja California. The known magnitudes of these previous events suggest that earthquakes in San Diego could attain a magnitude of approximately 6.5. An offset of the coast at Point La Jolla, when divided by the offset associated with previously studied earthquakes of magnitude 6.5, suggests that such events occur there at an average of approximately once every $600 \mathrm{yr}$.
\end{abstract}

The San Diego embayment contains Cretaceous, Tertiary, and Quaternary strata (Kennedy and Moore, 1971). These strata are generally nearly flat lying but are locally folded and cut by normal and right-lateral faults within a deformed belt that parallels the northwest-trending axis of San Diego Bay. This deformed belt, called the Rose Canyon fault zone, is exposed southeast of San Diego Bay in California and Baja California beside the delta of the Tijuana River (Ziony, 1973) and is especially well exposed in hilly terrain northwest of the bay (Kennedy, 1969).

In the present investigation, acoustic-reflection methods were used aboard a Scripps Institution of Oceanography vessel to map the faults under San Diego Bay and under the adjacent bight outside Silver Strand barrier beach. Navigational fixes, by horizontal sextant angles, had a maximum error of $100 \mathrm{~m}$ within the bay and $300 \mathrm{~m}$ outside the bay. The sound source for the survey was a spark array with 60 electrodes that reached a subbottom penetration of about $200 \mathrm{~m}$. Discharge of $5 \mathrm{~J}$ at each electrode reduced reverberation and allowed stratigraphic resolution of about $1 \mathrm{~m}$.

\footnotetext{
1 California Division of Mines and Geology.
}

Acknowledgments.-We are indebted to John $\mathrm{H}$. Foster, Neil F. Marshall, and Edward E. Welday, who participated in the cruise and in the analysis of the data.

\section{FAULT PATTERN}

The subbottom survey of the bay and bight revealed many faults. In fact, so many faults exist that we found it difficult to correlate the smaller ones from track to track, despite an average profile spacing of about $500 \mathrm{~m}$ in the bay and $1 \mathrm{~km}$ in the bight. The most conspicuous faults revealed by the survey are plotted in figure 1 , and selected profiles are reproduced in figure 2.

In the bight, most faults extend up to the sea floor, a truncated surface generally overlain by virtually no Holocene deposits (fig. 2, profile $C-C^{\prime}$ ). Most of the faults, which trend slightly east of north (fig. 1), show displacement downward to the east toward the San Diego structural basin, which is centered offshore near the city of Imperial Beach. Within San Diego Bay, the fault pattern includes several conspicuous northwest-trending fault strands. At some crossings of these strands as well as at some faults in the bight, the deformation bears features suggestive of strike-slip displacement, such as minor fault-bounded anticlines, chevron-shaped dilational synclines, and other complex folds that are not in harmony with dip-slip drag.

Faults such as La Nacion fault to the east of San Diego Bay (Artim and Pinckney, 1973), while possessing similar trends, have a mirror-image sense of displacement, downfaulted toward the bay and the San Diego structural basin (fig. 3). The regional array of faults in the San Diego area suggests that the pattern of the Rose Canyon fault zone broadens and becomes en echelon at the San Diego basin. The downfaulting toward San Diego Bay from both sides is clearly related to the origin of the bay and of the structural basin. We believe that the basin is an area of tension at a junction between right-stepping strands of the right-lateral fault zone. 


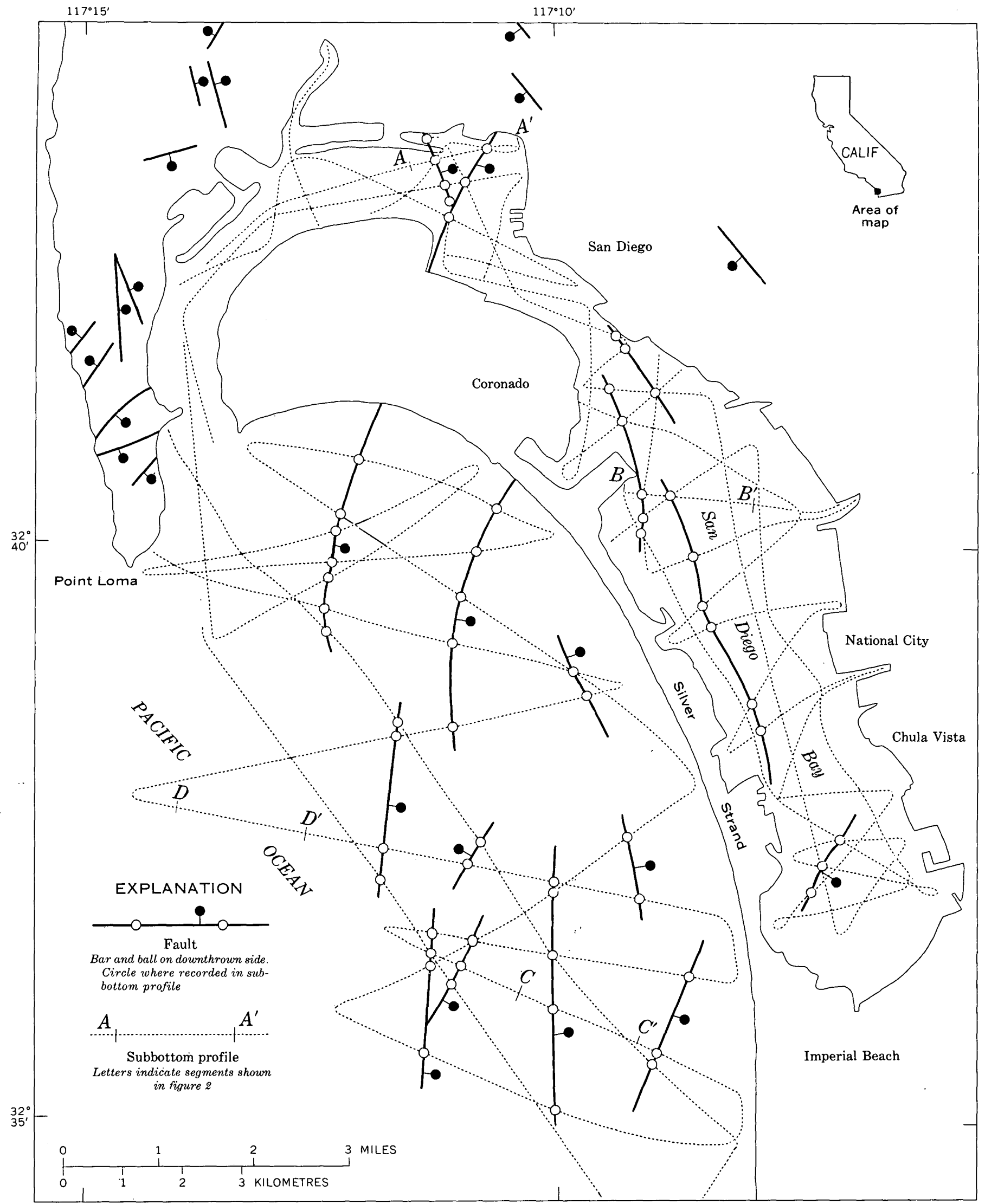

FIGURE 1.-Location of conspicuous faults: on floor: of :San:Diego Bay and adjacent areas. 
WEST

EAST

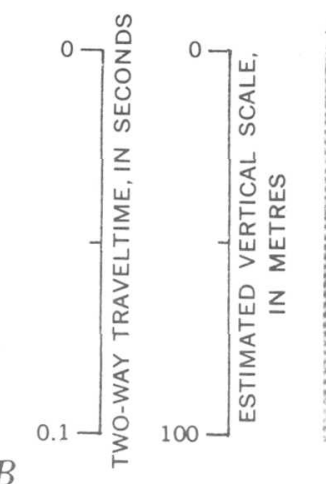

$A$

$A^{\prime}$
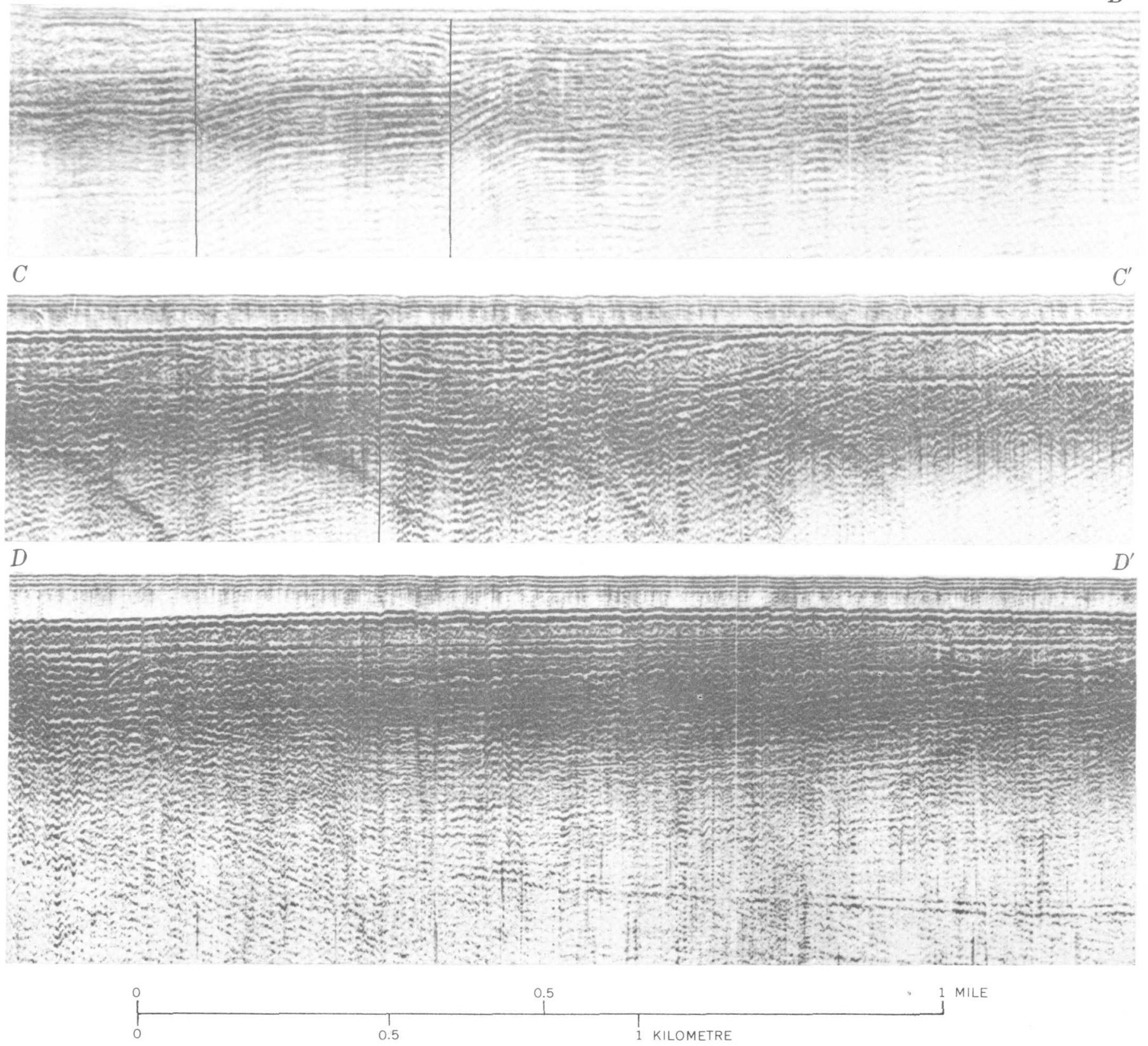

Figure 2.-Selected acoustic-reflection profiles of the floor of San Diego Bay and adjacent areas on which the larger faults have been inked. The horizontal scale is approximate owing to minor changes in vessel speed along the tracks. See figure 1 for locations. 


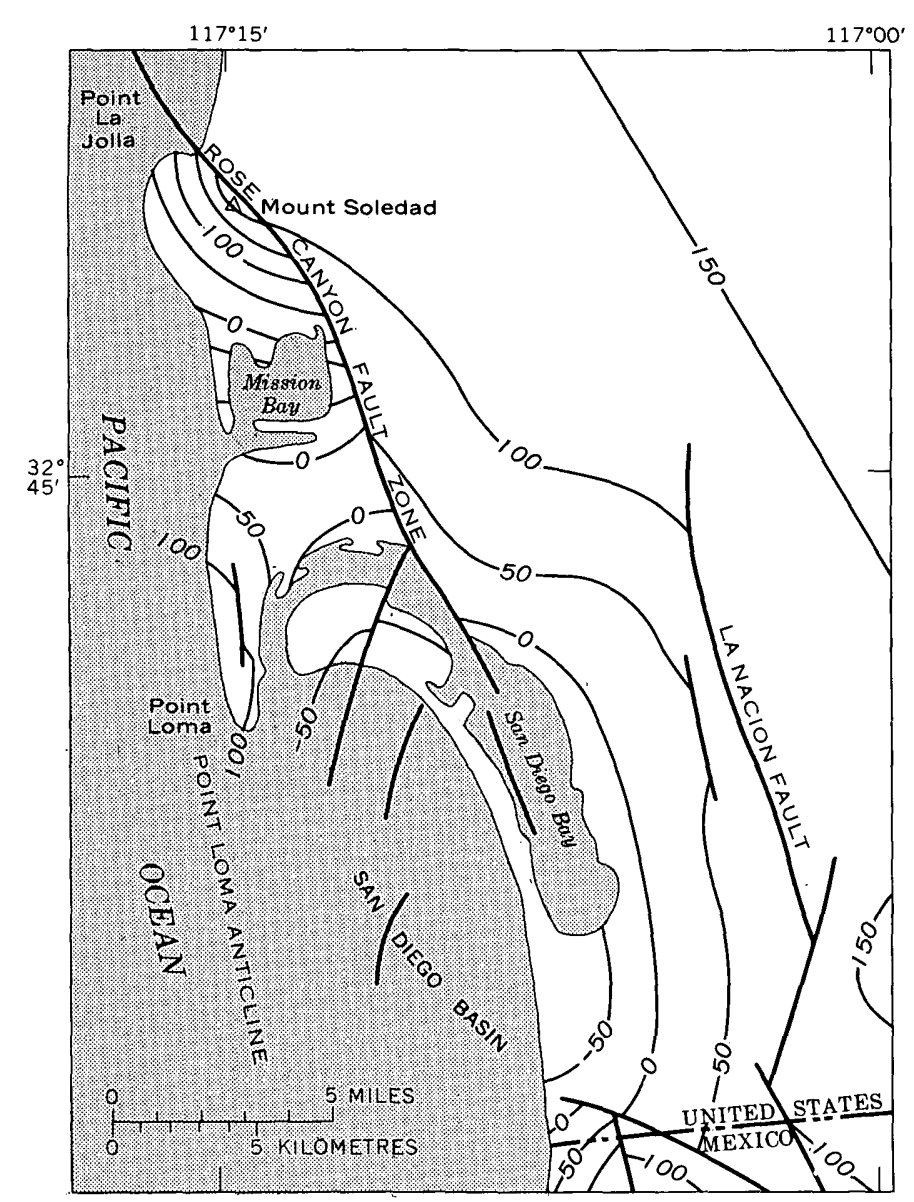

FIgURE 3.-Structure contours drawn on a wave-cut surface of early Pleistocene age at the base of the Lindavista Formation, showing offset and folding associated with major faults of the Rose Canyon fault zone, indicated by heavy lines. Contour interval, $50 \mathrm{~m}$. Datum is mean sea level.

\section{AGE OF FAULTED STRATA}

The San Diego basin contains a thick section of Pliocene and Pleistocene deposits. 'The axis of downwarping in the basin has migrated toward the west with time, and the Pliocene San Diego Formation now crops out in a crescentic belt on the east side of the basin beyond about $4 \mathrm{~km}$ east of San Diego Bay. Thick Pleistocene deposits occur farther seaward. A sample considered probably Pleistocene on the basis of contained species of pine and sunflower pollen and the absence of palynomorphs indicative of a Pliocene age occurs at a depth of $36 \mathrm{~m}$ at the bottom of a boring at lat $32^{\circ} 37.6^{\prime} \mathrm{N}$., long $117^{\circ} 06.3^{\prime} \mathrm{W}$., on the bay shoreline at Chula Vista (Jane Gray, written commun., 1968). At San Diego-Coronado Bridge Borehole No. 8, approximately in the middle of the bridge, Turritella gonostoma, a fossil gastropod known only from the Pleistocene in southern California, occurs at a depth of $47 \mathrm{~m}$ (W. J. Zinsmeister, written commun., 1974).
The Pleistocene is reported to be $91 \mathrm{~m}$ thick in an exploratory oil well near Imperial Beach (Hertlein and Grant, 1944, p. 59).

'Two Pleistocene formations occur in the San Diego basin, the Bay Point Formation of late Pleistocene age and the Lindavista Formation of early Pleistocene age. The Bay Point Formation, inferred to have been deposited approximately 100,000 yr ago during Sangamon time when sea level was about $8 \mathrm{~m}$ higher than it is now, occurs as shelly sand in thin discontinuous patches as on the flanks of Point Loma, on the landward shore of San Diego Bay, near the coast at the international border, and at the city of Coronado (Stephens, 1929). The deposit at Coronado is believed to be a former barrier beach adjusted to the higher stand of sea level and hence alined about $1 \mathrm{~km}$ landward from the axis of the present Silver Strand barrier beach. To the south of Coronado the Sangamon barrier beach is submerged in the center of the sinking basin, and on land near the axis of the actively rising Point Loma anticline the Bay Point Formation is abnormally high at about $15 \mathrm{~m}$.

The Lindavista Formation occurs as a terrace deposit a few metres thick at an average altitude of about $125 \mathrm{~m}$ over much of San Diego; locally it contains molluscan fossils (Kennedy, 1973). The formation is faulted and gently folded, slopes downward in the San Diego basin, and passes below sea level about $1 \mathrm{~km}$ east of the bay (fig. 3). Strata of the Lindavista Formation constitute the main part of the record in the acousticreflection profiles of this study. Offshore, near the east flank of the Point Loma anticline, where the Lindavista Formation lies with angular discordance on older rocks, the formation reaches a thickness of about $120 \mathrm{~m}$ (fig. 2, profile $D-D^{\prime}$ ).

All the faults mapped in this study are believed to offset the Lindavista Formation, and the faulting is therefore younger than early Pleistocene. This is in harmony with the known relation on land where the Rose Canyon, La Nacion, and other faults also offset the Lindavista Formation (Moore, 1972; Artim and Pinckney, 1973).

Within San Diego Bay, vertical offsets of the order of $10 \mathrm{~m}$ occur at a subbottom depth of about $30 \mathrm{~m}$ in strata believed to belong to the Lindavista Formation (fig. 2, profile $B-B^{\prime}$ ). Small offsets also occur in deposits of uncertain age at shallower depth. A possible Holocene age for faulting is suggested by a profile at the edge of the pre-1853 delta of the San Diego River that shows offsets of $1-2 \mathrm{~m}$ within $10 \mathrm{~m}$ of the bay floor (fig. 2, profile $A-A^{\prime}$ ).

In the San Diego Bight, where the Lindavista Formation was truncated during the Holocene trans- 
gression (approximately 10,000 yr ago), most movement on the faults there took place before the truncation. On some faults, however, steps 1-2 $\mathrm{m}$ high occur at the sea floor (fig. 2, profile $C-C^{\prime}$ ). Although differential erosion along the wave-cut platform cannot be entirely discounted, this evidence suggests that Holocene movement has taken place. Definite evidence, at least for post-Sangamon movement on this family of faults, comes from the land on nearby Point Loma where Kern (1973) reports that the fault nearest the point (fig. 1) offsets the Bay Point Formation a total of $12 \mathrm{~m}$. Also, to the north at Point La Jolla, the Bay Point Formation has been uplifted about $30 \mathrm{~m}$ adjacent to the Rose Canyon fault zone (Peterson, 1970).

\section{RATE OF DEFORMATION AND EARTHQUAKES}

Previous investigations of the Rose Canyon fault zone onshore and this offshore survey indicate a systematic relation between the maximum dip-slip offset along individual faults and the age of the displaced beds. Vertical offset is $30-130 \mathrm{~m}$ for the Lindavista Formation (approximately 1,000,000 yr), 12-30 m for the Bay Point Formation (100,000 yr), and probably 1-2 $\mathrm{m}$ for the Holocene platform (10,000 yr).

Strike-slip displacement also can be measured along the fault zone. The north edge of the San Diego basin has been offset $6 \mathrm{~km}$ right laterally, as marked by the Eocene-Pliocene unconformity at Mission Bay (Kennedy and Moore, 1971, fig. 1). The 200-m depth contour has been offset about $4 \mathrm{~km}$ right laterally where the fault zone passes out to sea near Point La Jolla. We believe that the larger part of the displacement on the fault zone is strike-slip, and that the generally more easily observed vertical displacement is an effect of it.

Near the shoreline, wave erosion that preceded deposition of the Lindavista Formation has removed topographic evidence of displacement older than approximately 1,000,000 yr. At Mount Soledad, the Lindavista Formation and underlying rocks have been uplifted $130 \mathrm{~m}$ adjacent to the Rose Canyon fault zone as a result of compression caused by strike-slip móvement at an S-shaped bend in the fault zone (Moore, 1972). The coast on opposite sides of the fault zone where it passes out to sea near Point La Jolla has rocks of similar resistance to erosion and a similar structural elevation of the Lindavista Formation. The southwest coast has been moved seaward right laterally about $1 \mathrm{~km}$ to form the point. Hence, in the Mount SoledadPoint La Jolla area, where the maximum vertical uplift is $130 \mathrm{~m}$, the vertical displacement is about 13 percent of the horizontal. To the south at Mission
Bay, a presumably similar horizontal slip, but along an oppositely curved length of the fault zone, is associated with a contrasting downward displacement of the Lindavista Formation to a position below sea level (Peterson, 1970).

The Quaternary deformation along the Rose Canyon fault zone attests to the tectonic importance of the zone. Although no major earthquakes have occurred near San Diego in historic time, several earthquakes of about magnitude $(M) 3.5$ have been recorded around San Diego Bay during the past $41 \mathrm{yr}$ of systematic earthquake data collection (fig. 4). Eleven took place near the Rose Canyon fault zone within the city of San Diego. As the magnitude of an earthquake is known to bear a systematic relation to slip along a fault (Bonilla and Buchanan, 1970), and as our field studies have revealed no fault creep in San Diego, the magnitude-slip relation can be used to evaluate whether these recorded earthquakes are sufficiently frequent to account for the observed Quaternary deformation.

Bonilla and Buchanan (1970) have shown that individual earthquakes of $M 3.5$ are associated with an offset of about $8 \mathrm{~mm}$ and a fault rupture length of $1 \mathrm{~km}$. The 1-km offset of the coast at Point La Jolla that has occurred in the approximately 1 million years since the Lindavista Formation was laid down indicates an average horizontal slip there of $1 \mathrm{~m} / 1,000 \mathrm{yr}$ or $1 \mathrm{~mm} / \mathrm{yr}$.

If this long-term rate of offset were related only to earthquakes of M 3.5, such as the eleven that occurred in San Diego during the past $41 \mathrm{yr}$, then an average of 2.5 earthquakes associated with surface offset would be expected on each $1-\mathrm{km}$ segment of the fault zone during the 41-yr period of record. The actual number is less than that by more than an order of magnitude, as an average of 0.2 earthquakes per kilometer occurred near the $50-\mathrm{km}$ length of the fault zone in San Diego, and some segments more than $10 \mathrm{~km}$ long had none. Furthermore, not all the faulting associated with earthquakes of M 3.5 would be likely to cut the surface, as that would require nonseismic creep below about $1 \mathrm{~km}$, a depth equal to their length of rupture (Brune, 1968). Assuming that the seismicity extends to a depth of at least $15 \mathrm{~km}$, as is the case elsewhere in California, nearly 1,000 earthquakes of M 3.5 would have been expected in San Diego during the past $41 \mathrm{yr}$. The great inadequacy of the 11 earthquakes that did occur to account for the indicated long-term rate of slip suggests that strain for a larger earthquake may be accumulating.

The Rose Canyon fault zone is believed to be tectonically related to the Newport-Inglewood fault zone of the Los Angeles area. Both lie in similar structural 


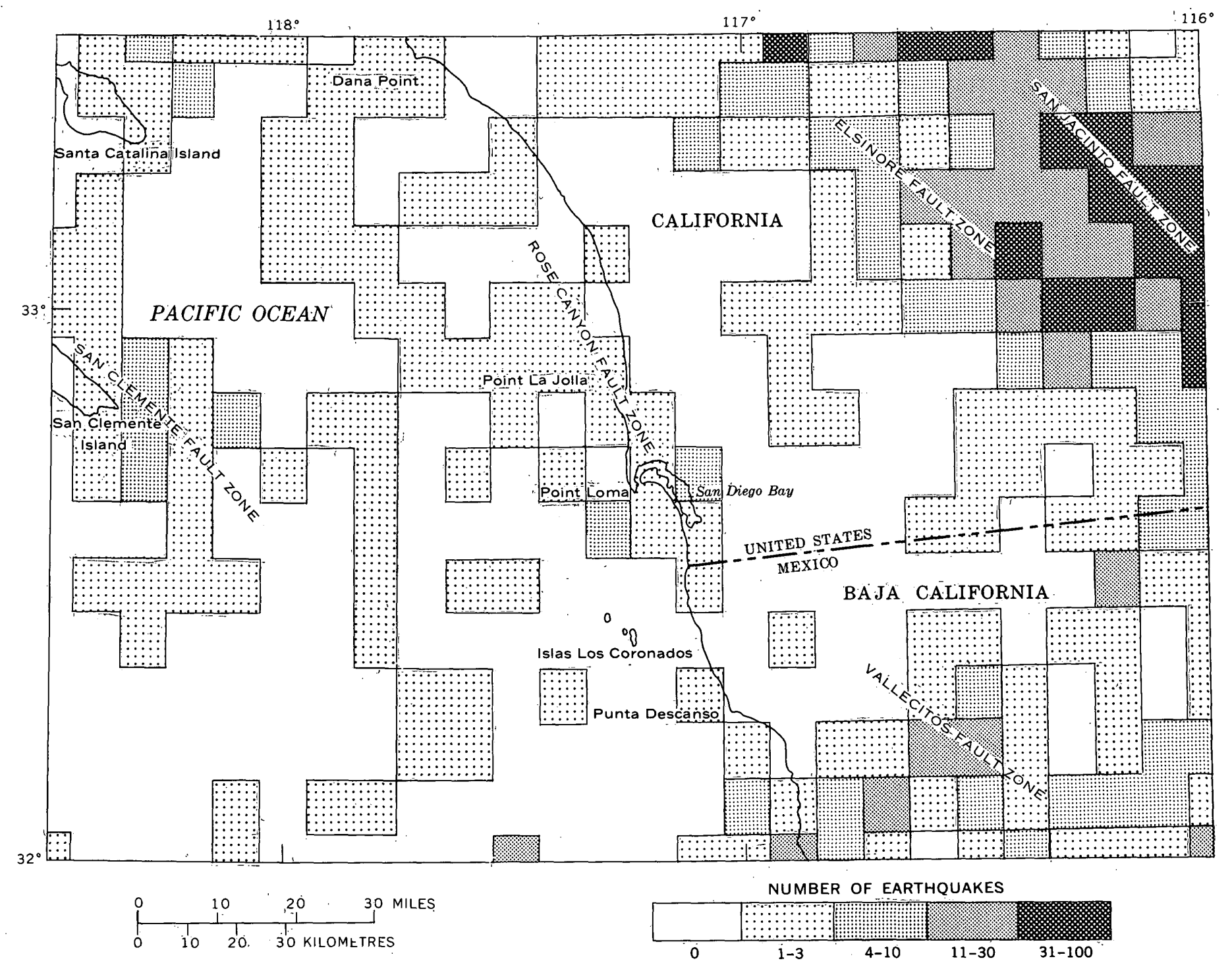

FIGURE 4.-Frequency of earthquakes of magnitude 3 and greater in each square one-tenth of a degree of latitude and longitude near San Diego Bay, 1932-72. Data from Hileman, Allen, and Nordquist (1973).

positions on the west side of the batholithic Santa Ana block (Morton and Gray, 1971), a nearly earthquakefree block that is bounded on the east by the Elsinore fault zone and that extends from the Los Angeles basin to the San Miguel fault zone in Baja California. Earthquakes of approximately M 6.5 were recorded at Long Beach, Calif., in 1933, and at San Miguel, Baja California, in 1956. If these can be inferred to be the principal earthquakes that occur along the west side of the Santa Ana block, then their expected frequency can be calculated along fault-zone segments where the rate of slip has been estimated.

Earthquakes of M 6.5 are associated with a surface rupture approximately $25 \mathrm{~km}$ long and have an offset of about $0.6 \mathrm{~m}$ (Bonilla and Buchanan, 1970). On the basis of the estimated slip rate of $1 \mathrm{~m} / 1,000 \mathrm{yr}$ at
Point La Jolla, (both this rate and the inferred magnitude are subject to uncertainties), such an event could occur there once every $600 \mathrm{yr}$. Within the city of San Diego, which lies along about $50 \mathrm{~km}$ of the fault zone, (or two M 6.5 rupture lengths), an earthquake of approximately magnitude 6.5 would be expected every $300 \mathrm{yr}$ on the average.

\section{REFERENCES CITED}

Artim, E. R., and Pinckney, C. J., 1973, La Nacion fault system, San Diego, California, in Studies on the geology and geologic hazards of the greater San Diego area, California: San Diego Assoc. Geologists Guidebook, p. 77-82.

Bonilla, M. G., and Buchanan, J. M., 1970, Interim report on worldwide historic surface faulting: U.S. Geol. Survey open-file rept., $32 \mathrm{p}$. 
Brune, J. N., 1968, Seismic moment, seismicity, and rate of slip along major fault zones: Jour. Geophys. Research, v. 73, p. 777-784.

Hertlein, L. G., and Grant, U. S., 4th, 1944, The geology and paleontology of the marine Pliocene of San Diego, California, pt. 1, Geology : San Diego Soc. Nat. History Mem. v. 2, p. 1-72.

Hileman, J. A., Allen, C. R., and Nordquist, J. M., 1973, Seismicity of the southern California region, 1 January 1932 to 31 December 1972: Pasadena, California Inst. Technology, $487 \mathrm{p}$.

Kennedy, G. L., 1973, A marine invertebrate faunule from the Lindavista Formation, San Diego, California: San Diego Soc. Nat. History Trans., v. 17, p. 119-127.

Kennedy, M. P., 1969, Preliminary geologic map of a portion of northwestern San Diego city, California : California Div. Mines and Geology open-file rept. 69-13, scale 1:9,600.

Kennedy, M. P., and Moore, G. W., 1971, Stratigraphic relations of Upper Cretaceous and Eocene formations, San Diego coastal area, California: Am. Assoc. Petroleum Geologists Bull, v. 55, p. 709-722.
Kern; J. P., 1973, Late Quaternary deformation of the Nestor terrace on the east side of Point Loma, San Diego, California, in Studies on the geology and geologic hazards of the greater San Diego area, California: San Diego Assoc. Geologists Guidebook, p. 43-45.

Moore, G. W., 1972, Offshore extension of the Rose Canyon fault, San Diego, California: U.S. Geol. Survey Prof. Paper 800-C, p. C113-C116.

Morton, D. M., and Gray, C. H., Jr., 1971, Geology of the northern Peninsular Ranges, southern California : California Univ. Riverside Mus. Contr., no. 1, p. 60-93.

Peterson, G. L., 1970, Quaternary deformation patterns of the San Diego area, southwestern California: Am. Assoc. Petroleum Geologists, Pacific Sec., Fall 1970 Guidebook, p. 120-126.

Stephens, Frank, 1929, Notes on the marine Pleistocene deposits of San Diego County, California: San Diego Soc. Nat. Hist. Trans., v. 5, p. 245-255.

Ziony, J. I., 1973, Recency of faulting in the greater San Diego area, California, in Studies on the geology and geologic hazards of the greater San Diego area, California: San Diego Assoc. Geologists Guidebook, p. 68-75. 


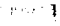


Jour. Research U.S. Geol. Survey

Vol. 3, No. 5, Sept.-Oct. 1975, p. 597-604

\title{
AGE OF VOLCANISM, INTRUSION, AND MINERALIZATION IN THE THOMAS RANGE, KEG MOUNTAIN, AND DESERT MOUNTAIN, WESTERN UTAH
}

\author{
By DAVID A. LINDSEY; CHARLES W. NAESER, and DANIEL R. SHAWE, \\ Reston, Va.; Denver, Colo.
}

\begin{abstract}
Twenty-six new age determinations by the fissiontrack method establish a chronology for volcanism, intrusion, and mineralization in the Thomas Range, Keg Mountain, and Desert Mountain, in western Utah. The fission-track ages confirm D. R. Shawe's three-fold classification of igneous rocks. The oldest group of rocks consists of flows, agglomerates, and some ash-flow tuffs that were deposited 38-39 m.y. ago. The middle group contains widespread rhyolitic ash-flow tuffs that originated from local volcanic centers $30-32$ m.y. ago. A dike emplaced along the probable ring-fracture zone of the Keg caldera about 31 m.y. ago indicates that caldera collapse occurred soon after eruption of ash-flow tuffs. Rocks believed to belong-to the middle group also were intruded by the quartz monzonite of Desert Mountain 27-30 m.y. ago. Little or no igneous activity took place within the next 20 m.y., during which time the region was strongly broken by Basin-and-Range faulting. Rhyolites of the youngest group were extruded 8-10 m.y. ago in the Keg Mountain area and 6-7 m.y. ago in the Thomas Range. The beryllium-fluorite mineralization at Spor Mountain occurred after the rhyolitic volcanism in the Thomas Range.
\end{abstract}

Volcanic rocks in the Thomas Range, Keg Mountain, and Desert Mountain (fig. 1) are an important part of the Tertiary rock sequence of western Utah. These rocks constitute a thick sequence of lava flows and ashflow tuffs overlain by extensive flows of alkali rhyolite. Beryllium, fluorspar, manganese, and uranium deposits are associated spatially, and probably genetically, with the volcanic pile. The topaz-bearing rhyolites of the Thomas Range have been the subject of scientific interest for nearly a century (Cross, 1886, p. 436-438), and the beryllium deposits at Spor Mountain are the largest known economically recoverable resources of this metal in the world (Griffitts, 1964, p. 71-74). Until recently, data on the age of the volcanic rocks have been inadequate to delineate the history of volcanism, intrusion, and mineralization. This report provides new age data that establish the broad outline of igneous evolution and mineralization.

Acknowledgments.-We thank Gary Lenz and Ezekiel Rivera for their assistance in preparing min- eral separates. E. H. McKee provided a K-Ar date on the topaz-bearing rhyolite of the Thomas Range.

\section{DESCRIPTION OF IGNEOUS ROCKS}

The igneous rocks of the region can be divided into three groups (termed "assemblages" by Shawe, 1972). They will be described only briefly here, and the reader is referred to Staatz and Carr (1964) and Shawe (1972) for detailed descriptions of their petrography and structural setting.

The oldest group of rocks consists of dark flow rocks and agglomerates of andesitic basalt, andesite, latite, and rhyodacite. Tuffs of intermediate and silicic composition are interbedded with flows and agglomerates. Much of the oldest group in the Keg Mountain area consists of olive to gray flows that were called the Keg Spring andesite and latite by Erickson (1963, p. 26). Two samples of these flows were selected for dating the onset of extensive volcanism. A rhyolitic ash-flow tuff that crops out east of Topaz Mountain also was sampled; this rock unit had been classified as a variant of porphyritic rhyolite by Staatz and Carr (1964, p. 83) and correlated with rocks of the middle group by Shawe $(1972$, p. B71), but age data presented in this report clearly place the rhyolitic tuff in the oldest group.

The middle group consists mainly of ash-flow tuffs of dacitic to rhyolitic composition. A gray dacitic to quartz-latitic tuff occurs at the base of the middle group at the north end of the Drum Mountains and at the northwestern part of the Keg Mountain area. This tuff is probably the plagioclase crystal tuff of Staatz and Carr (1964, p. 78-79) in the Thomas Range. It is overlain by an extensive unit of pink to brown rhyolitic tuff which contains abundant quartz and sanidine crystals (the sanidine crystal tuff and the quartz-sanidine crystal tuff of Staatz and Carr, 1964, p. 79-81). Because of the wide extent of the rhyolitic tuff, four samples for dating were collected from the Thomas 


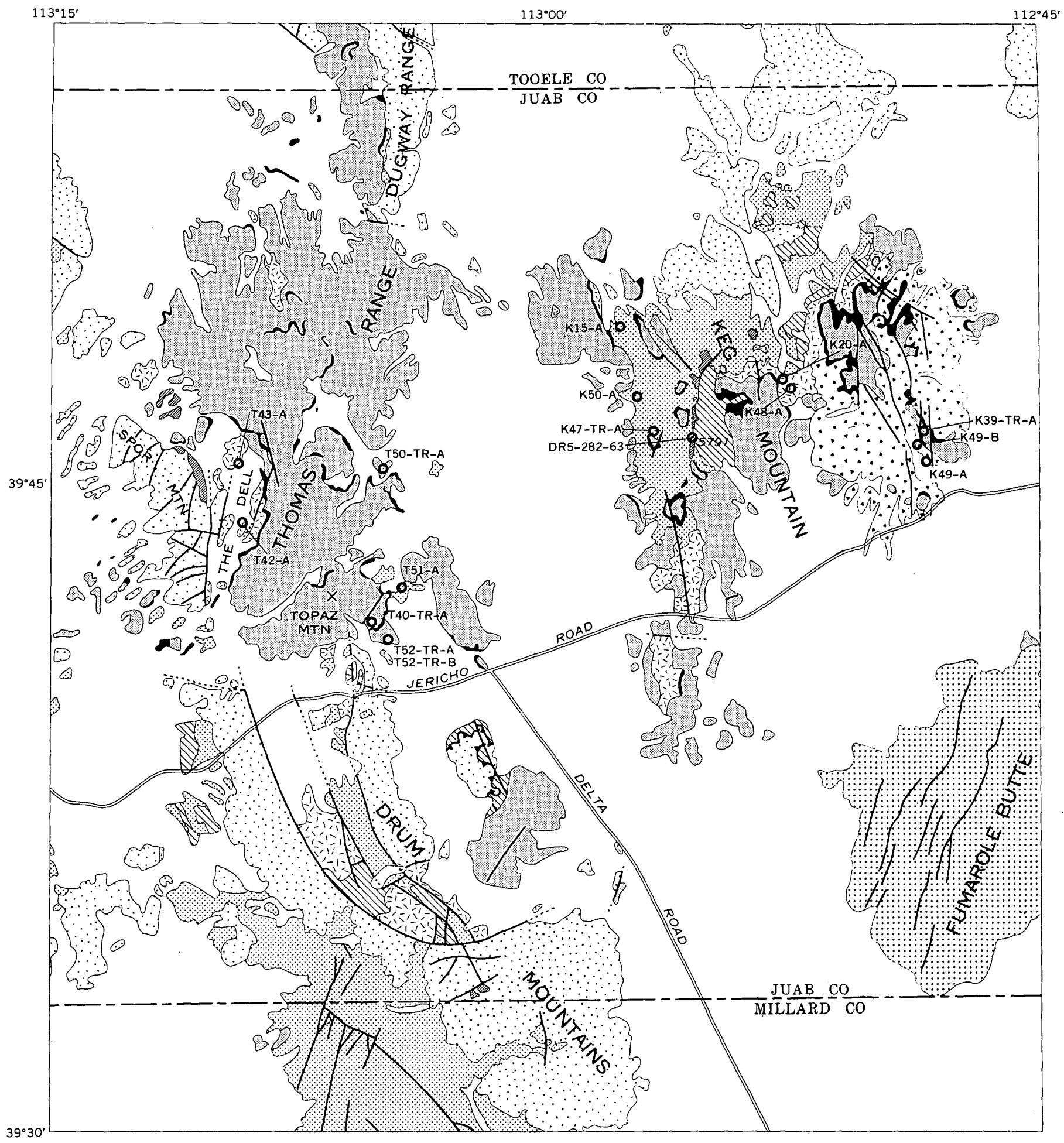

Range and the Keg Mountain area. Two samples from the Thomas Range are hydrothermally altered quartzsanidine crystal tuff from. The Dell; they were selected to examine the possibility that apatite contained in the tuff might have been annealed by the hydrothermal activity at Spor Mountain. The youngest ash-flow unit of the middle group is a light-brownish-gray quartz- latitic to rhyolitic tuff in the northern part of the Drum Mountains; no sample was collected for dating. Ash-flow tuffs which probably belong in the middle group are also present on the east flank of Desert Mountain, where they are intruded by the quartz monzonite of Desert Mountain. A sample of quartz monzonite was collected to provide a crosscheck between 

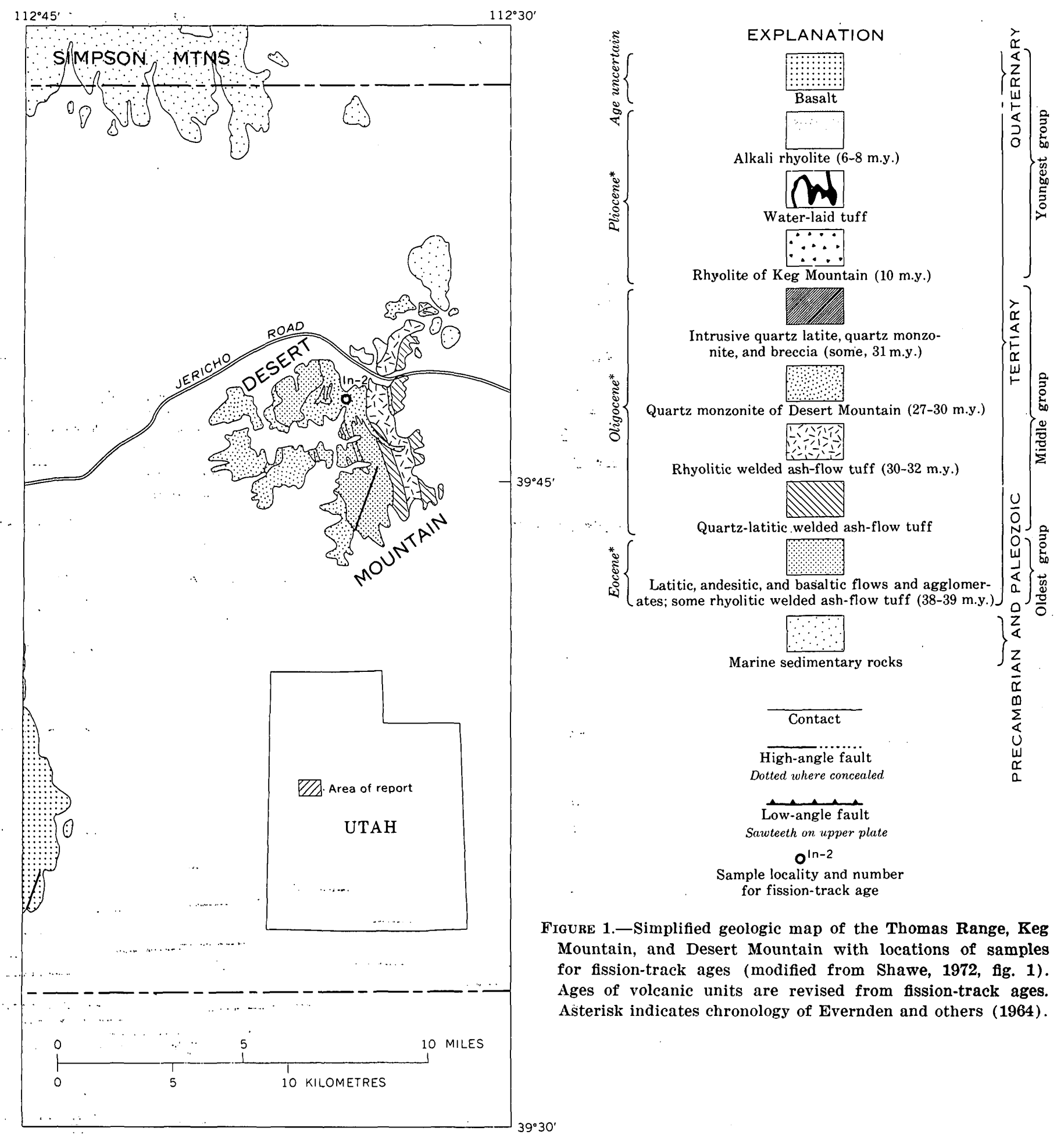

Figure 1.-Simplified geologic map of the Thomas Range, Keg Mountain, and Desert Mountain with locations of samples for fission-track ages (modified from Shawe, 1972, fig. 1). Ages of volcanic units are revised from fission-track ages. Asterisk indicates chronology of Evernden and others (1964).

our fission-track ages and ages previously obtained by Armstrong (1970; table 3) by the K-Ar method.

Quartz latite porphyry forms dikes and small plugs which are thought to follow the trend of the ring-fracture zone of the $\mathrm{Keg}$ caldera (Shawe, 1972, p. B72$\mathrm{B} 73)$. If so, the intrusions were emplaced during or after development of the Keg caldera. A sample from a dike of quartz latite porphyry was obtained to fix the minimum age of the caldera.

The youngest group of volcanic rocks consists entirely of rhyolite flows, water-laid tuff, and the basalt of Fumarole Butte. The lowermost flow is the rhyolite of Keg Mountain, a distinctive porphyritic rock containing abundant large plagioclase phenocrysts and 
clusters of quartz, plagioclase, biotite, and magnetite phenocrysts. This unit was described by Shawe (1972, p. B71) as the uppermost unit of the middle group of igneous rocks, but age data presented in this report clearly associate it with the youngest group. It is overlain by as much as $100 \mathrm{ft}(30 \mathrm{~m})$ of water-laid tuff and by extensive flows of alkali rhyolite. Both the rhyolite of Keg Mountain and the overlying alkali rhyolite were sampled to date the onset and duration of rhyolitic volcanism in the Keg Mountain area. The Thomas Range contains at least five sequences of waterlaid tuff overlain by alkali rhyolite (Staatz and Carr, 1964, p. 86-102). The rhyolites of the Thomas Range are distinctive in that they contain abundant topaz and rare garnet, beryl, bixbyite, and pseudobrookite in lithophysal cavities (Staatz and Carr, 1964, p. 102109). Numerous samples were examined from the various flows, but only those from the third flow in the eastern part of the range and the fourth and fifth (uppermost) flows on Topaz Mountain yielded accessory zircon that could be dated. As will be discussed later, the age of the flows on Topaz Mountain is critical to dating the beryllium and fluorspar mineralization at Spor Mountain.

\section{DESCRIPTION OF ACCESSORY MINERALS}

Distinctive assemblages of accessory heavy minerals are present in the volcanic rocks. Three of these minerals-sphene, zircon, and apatite- were used to determine the fission-track ages reported here. The paragenesis and individual characteristics of the accessory minerals have a direct bearing on interpretation of the ages.

Most rocks of the oldest and middle groups contain magnetite, hematite, allanite, sphene, colorless zircon, and apatite. Sphene, zircon, and apatite generally occur as microphenocrysts that are associated with one another. All are abundant within or along the margins of biotite and magnetite grains and apatite is especially concentrated in biotite phenocrysts. All three minerals also occur in the groundmass of the volcanic rocks, and they are present both as broken and euhedral crystals in the ash-flow tuffs. The textural relationships of these three accessory minerals establish that they crystallized within the parent magma and were not derived from exotic sources.

Uranium in both sphene and apatite of the oldest and middle groups tends to be uniformly distributed within individual grains. In many zircon grains, however, uranium and the resulting fission tracks are zonally distributed. Such grains are unsuited for fission-track dating, and age determinations were made only on relatively unzoned grains. The problem of zoning is most severe in the case of zircons from the Keg Spring andesite and latite of Erickson (1963) in the oldest group. The resulting fission-track ages of individual zircon grains from the Keg Spring unit thus show more variation than the ages measured on zircons of other rock units.

The quartz monzonite of Desert Mountain contains abundant magnetite and lesser amounts of hematite, pink zircon, sphene, and apatite. Microphenocrysts of pink zircon and sphene were recovered in sufficient amounts for dating. The dike of quartz latite porphyry that was sampled northwest of Keg Mountain contains abundant magnetite and lesser quantities of allanite, pink zircon, and apatite; the zircon was used for dating.

The rhyolite of Keg Mountain contains a distinctive assemblage of accessory heavy minerals consisting of magnetite, lesser hematite, large (60-mesh) euhedral crystals of pink zircon, and colorless and red-brown varieties of apatite. Only trace amounts of sphene are present. Both zircon and apatite occur as microphenocrysts in clusters of quartz, plagioclase, biotite, and magnetite phenocrysts, as inclusions in phenocrysts of biotite and magnetite, and in the groundmass of the rock. The clusters of phenocrysts have delicate shapes and consist of resorbed euhedral to subhedral grains which formed early during crystallization of the magma, and under conditions different from those that prevailed when the rhyolite magma was extruded. Many zircon grains are relatively unzoned and contain less uranium (230-240 ppm) than does zircon from most of the other volcanic rocks in this area. Much of the apatite contains numerous inclusions that preclude the counting of fission tracks.

The main accessory mineral in the alkali rhyolites of Keg Mountain is specular hematite. No topaz was identified. Of four samples examined, only one contained small microphenocrysts of pink to colorless zircon. Sphene is not normally present in the rhyolite, but sphene-rich inclusions are present at the base of the rhyolite in the western part of the range, where the rhyolite overlies the Keg Spring andesite and latite of Erickson (1963). The inclusions show various stages of assimilation. The sphene grains are very ragged and have thick, darkened rinds that suggest reaction with the rhyolite lava.

The alkali rhyolites of the Thomas Range contain abundant specular hematite and topaz. Small (200mesh) euhedral to subround microphenocrysts of zircon are present in the matrix of the rhyolite and were recovered from a few samples. Some are pale pink, but most are colorless to translucent gray. The zircon is 
commonly zoned and has the highest uranium content ( $\approx 5,000 \mathrm{ppm}$ and more) of all zircon examined; many grains are metamict. Only those few grains containing uniformly distributed uranium were utilized for fission-track dating.

\section{TECHNIQUES OF FISSION-TRACK DATING}

Fission tracks are the defect paths that result when heavy charged nuclei pass through a crystal lattice. The tracks utilized in dating accessory minerals in geologic materials result from the spontaneous fission of ${ }^{238} \mathrm{U}$. The density of tracks in a crystal is a function of its uranium content and age. If the crystal is irradiated by thermal neutrons in a reactor, a new set of tracks is formed. The induced fission-track density can then be used to compute the uranium content and the age. Fission tracks are preserved over geologic time unless annealed by later heating. For thermal events of a million years duration, apatite is completely annealed at $170^{\circ} \mathrm{C}$, sphene at $420^{\circ} \mathrm{C}$, and zircon at nearly $500^{\circ} \mathrm{C}$ (Naeser and Faul, 1969; Fleischer and others, 1965a). A comprehensive discussion of fission-track theory and application is given by Fleischer, Price, and Walker (1965b).

A fission-track age is calculated from the following equation:

$$
A=\frac{1}{\lambda_{\mathbf{D}}} \ln \left(1+\frac{\rho_{8} \lambda_{\mathrm{D}} \sigma I_{\phi}}{\rho_{i} \lambda_{F}}\right)
$$

where $A=$ age in years,

$\rho_{s}=$ fossil-track density,

$\rho_{i}=$ induced-track density,

$\lambda_{D}=$ total decay constant for ${ }^{238} \mathrm{U}$ $\left(1.54 \times 10^{-10} \mathrm{yr}^{-1}\right)$

$\lambda_{F}=$ decay constant for spontaneous fission of ${ }^{238} \mathrm{U}\left(6.85 \times 10^{-17} \mathrm{yr}^{-1}\right)$,

$\sigma=$ thermal neutron fission cross section for ${ }^{235} \mathrm{U}\left(582 \times 10^{-24} \mathrm{~cm}^{2}\right)$,

$I=$ ratio of ${ }^{235} \mathrm{U} /{ }^{238} \mathrm{U}\left(7.26 \times 10^{-3}\right)$, and

${ }_{\phi}=$ neutron dosage in neutrons $/ \mathrm{cm}^{2}$.

The standard deviations of ages determined from sphene and zircon were computed as the Poissonian statistic:

where

$$
\sigma=\sqrt{\alpha^{2}+\beta^{2}}
$$

$\sigma=$ percent standard deviation,

$$
\begin{gathered}
\alpha=\frac{100}{\sqrt{N_{s}}} \text {, and } \\
\beta=\frac{100}{\sqrt{N_{i}}} .
\end{gathered}
$$

$N_{s}$ is the number of fossil tracks counted and $N_{i}$ is the number of induced tracks counted. This method of cal- culation includes counting error only; it also assumes that counting error associated with determination of the neutron dosage is negligible. Because the age of apatite is determined by counting two populations of grains, the standard deviation for apatite ages was not calculated by this method. Replicate determinations made on apatite from a single sample indicate that the standard deviation is about \pm 10 percent of the age (Naeser and Dodge, 1969, p. 2204).

Concentrates of sphene, zircon, and apatite were prepared by standard heavy-liquid and electromagnetic techniques for mineral separation. Accessory minerals were concentrated from the -60 to +120 mesh fraction; owing to its fine grain size, zircon from the alkali rhyolite was concentrated from the -60 to +230 mesh fraction. About 100-200 grains from each concentrate were mounted in clear epoxy resin on glass slides and were ground and polished to expose interior surfaces for etching (Naeser, 1967, p. 1524). After mounting and polishing, each of the minerals was treated differently.

Epoxy wafers containing ground and polished sphene were removed from the glass slides and etched for $1 \mathrm{~h}$ in $50 \mathrm{~N} \mathrm{NaOH}$ at $135^{\circ} \mathrm{C}$. Zircon was etched by a modification of the technique described by Naeser (1969). Wafers of zircon were removed and etched for $1-3 \mathrm{~h}$ in $135 \mathrm{~N} \mathrm{NaOH}$ at $270^{\circ} \mathrm{C}$. Because the wafer is decomposed during etching of zircon, the grains were recovered from the solution and mounted in lexan. The epoxy wafers containing sphene and the lexan wafers containing zircon were washed and a freshly cleaved plate of muscovite was taped to them in order to record fission tracks induced by radiation (Naeser and Dodge, 1969, p. 2203). After irradiation, the muscovite plate was removed and etched $11 \mathrm{~min}$ in 48 percent HF to expose the induced fission tracks. The wafers and corresponding muscovite detectors were mounted open-book fashion on a glass slide so that fossil and induced tracks of the same grain could be located and counted.

Apatite was treated by a modification of the method described by Naeser $(1967$, p. 1524) and Naeser and Dodge (1969, p. 2202). Concentrates of apatite were split into two groups of several hundred grains. One group was mounted and polished as described. The second group was wrapped in aluminum foil and heated overnight at $600^{\circ} \mathrm{C}$ to anneal the fossil fission tracks. This group was then irradiated, mounted, and polished in the usual fashion. The resulting two slides were etched in 7 percent $\mathrm{HNO}_{3}$ for $25 \mathrm{~s}$ to expose the fission tracks. The unheated apatite in the first slide contained fossil tracks, whereas the annealed apatite in the second slide revealed only induced tracks. Fis- 
sion tracks from 50 grains in each slide were counted to determine the fossil-track density and the inducedtrack density.

The neutron dosage was monitored by placing glass standards at the top and bottom of the radiation tube. The samples to be irradiated were placed between the standards and their positions were recorded. Glass standards containing a known amount of uranium were supplied by the National Bureau of Standards. Mica detectors were taped to the standards prior to irradiation. After irradiation, the detectors were etched $1 \mathrm{~h}$ in 48 percent $\mathrm{HF}$ and the fission tracks were counted to determine the neutron dosage. The dosage for each sample was determined by interpolation.

\section{DISCUSSION OF RESULTS}

The fission-track ages (table 1) provide a coherent chronological scheme that may be used as a basis for comparison with previously determined ages. The fission-track ages of 28.2 m.y. on sphene and 32.4 m.y. on zircon from quartz monzonite of Desert Mountain are similar to the K-Ar ages of $26.5 \mathrm{~m}$.y. on orthoclase and 28.5 m.y. on biotite reported by Armstrong (1970, table 3). The fission-track age of 6.1 m.y. for the uppermost rhyolite flow of Topaz Mountain agrees quite well with the K-Ar ages of 6.0 m.y. obtained by Armstrong (1970, table 3) and 6.1 m.y. obtained by E. H. McKee (oral commun., 1975) ; these ages do not agree with that of 16.2 m.y. reported by Park (1970, p. 23), indicating that the age reported by Park is probably in error. None of the previously determined $\mathrm{Pb}-\alpha$ ages (Jaffe and others, 1959, p. 71; Odekirk, 1970, p. 33) agree closely with the fission-track and $\mathrm{K}$-Ar ages (table 1 ); the $\mathrm{Pb}-\alpha$ ages are very approximate at best and are subject to major sources of error, so that their poor correlation with other ages is not significant. The fission-track ages are internally consistent, and ages determined on individual minerals from the same sample generally are within 10 percent of the average age. Ages determined on more than one sample from the same rock unit also indicate a similar degree of consistency.

The three-fold grouping of igneous rocks proposed by Shawe (1972) is supported by the fission-track chronology. The oldest group, consisting of flows and agglomerates of intermediate composition and some silicic ash-flow tuffs, is 38-39 m.y. old. This group probably corresponds to a thick sequence of flows and volcaniclastic rocks in the northern part of the Little Drum Mountains (south of the Drum Mountains), dated at $37.3 \mathrm{~m}$.y. by the K-Ar method (Leedom, 1974, p. 85). Dated rocks from the middle group, consisting mainly of ash-flow tuffs of intermediate to silicic composition, are 30-32 m:y. old. The ages of the oldest and youngest tuffs in the middle group have not been determined. Rocks that probably belong to the middle group were intruded by the quartz monzonite of Desert Mountain, which was dated as 26.5-28.5 m.y. old by the K-Ar method (Armstrong, 1970, table 3) and 28.232.4 m.y. by the fission track method. Fission-track dates from the youngest group, consisting mainly of rhyolite, range from 10 m.y. to 6 m.y. old. Rhyolite at Smelter Knoll, southeast of the Thomas Range, was dated by Armstrong (1970, table 3) as 3.4 m.y. old by the K-Ar method, indicating an even wider range in age for the youngest group. An apatite age of $\mathbf{1 3 . 6}$ m.y. from ash-flow tuff of the middle group at Keg Mountain probably resulted from partial annealing of the apatite during the eruption of rhyolite flows $8-10$ m.y. ago.

Several important revisions in the grouping of volcanic rocks of the Thomas Range and Keg Mountain are required by the fission-track ages. The oldest group contains more rhyolitic ash-flow tuff than previously thought. The tuff that crops out east of the Thomas Range had been correlated with the middle group (Shawe, 1972, p. B71; fig. 1), but fission track ages of 37.5 m.y. on sphene and 39.0 m.y. on apatite clearly place the unit at this locality in the oldest group. The numerous rock units defined and mapped by Staatz and Carr (1964, p. 73-86) in the Thomas and Dugway Ranges probably should be reexamined and dated in order to assign them with confidence to the grouping described here. The rhyolite of Keg Mountain (Shawe, 1972 , p. B71) was originally assigned to the middle group. Fission-track ages of 10.3 m.y. and 9.6 m.y. on zircon, however, place the rhyolite of Keg Mountain in the youngest group.

The fission-track chronology reported here clarifies the igneous and structural evolution and the history of mineralization of this part of the Basin and Range province. Following emplacement of the oldest group of volcanic rocks mostly as intermediate-composition central volcanoes (38-39 m.y. ago), the Desert, Keg, and Thomas calderas formed as a result of eruption of voluminous silicic ash-flow tuffs (30-32 m.y. ago). Emplacement of silicic magmas in resurgent domes and ring-fracture zones of the calderas followed closely; quartz monzonite of the Desert Mountain resurgent dome was emplaced 27-30 m.y. ago and quartz latite porphyry of the Keg ring-fracture zone was emplaced 31 m.y. ago. After a hiatus of about 20 m.y., rhyolite was extruded at Keg Mountain (8-10 m.y. ago) and topaz-bearing rhyolite and basalt flows were formed (6-7 m.y. ago and later). 


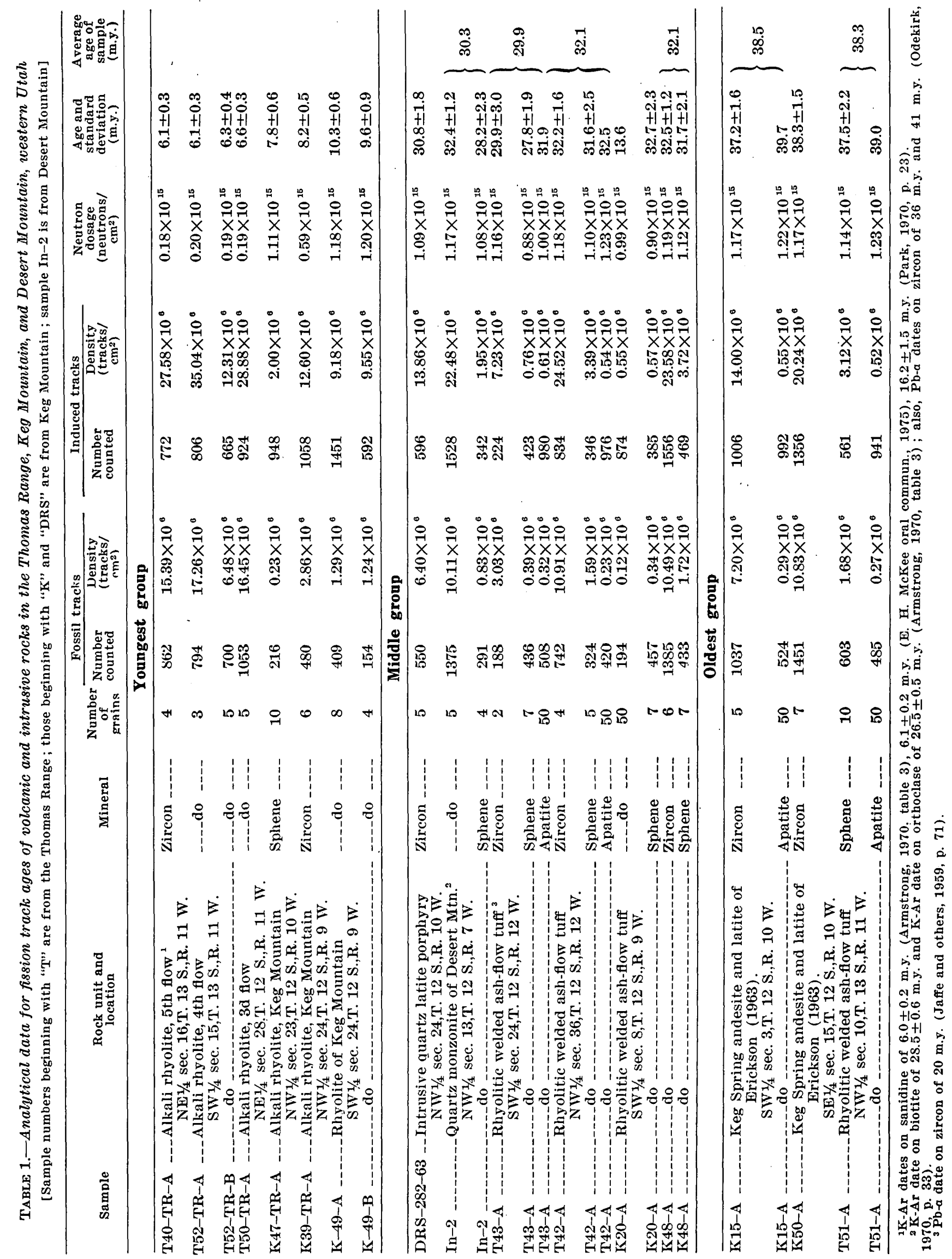


Fault-block structure that is characteristic of the Basin and Range province developed largely during the 20-m.y. interval between caldera collapse and extrusion of the youngest group of volcanic rocks. Volcanic rocks of the oldest and middle groups are extensively faulted, whereas the youngest group is cut by only a few faults (Staatz and Carr, 1964, p. 116, 128129). The interval coincides with, but is much longer than, the hiatus at 17-20 m.y. ago that is known to be present throughout the Basin and Range province (McKee and others, 1970).

The age of the topaz rhyolite probably indicates the age of beryllium-fluorite mineralization at Spor Mountain as well. A genetic relationship between the rhyolite and the beryllium and fluorspar deposits is suggested by the presence of anomalous beryllium and fluorine in the rhyolites (Staatz and Griffitts, 1961, p. 948-949; Lindsey and others, 1973, p. A18-A19), and the mineral deposits probably were formed during or shortly after extrusion of the topaz rhyolite. Along the south side of Topaz Mountain, water-laid tuff between the fourth (6.2 m.y.) and fifth (6.1 m.y.) rhyolite flows contains large dispersion halos of beryllium and other trace elements; isolated fluorite nodules are also present near the base of the tuff along the south side of Topaz Mountain (Lindsey, 1975). The mineralization that affected this tuff unit thus is younger than 6.1-6.2 m.y. An attempt to date the mineralization directly from apatite in altered ash-flow tuff of the middle group in The Dell was unsuccessful; apatite ages from this rock proved to be concordant with the ages obtained from sphene and zircon. The critical temperature necessary to anneal apatite $\left(170^{\circ} \mathrm{C}\right.$ for 1 m.y.) evidently was not approached.

\section{REFERENCES CITED}

Armstrong, R. L., 1970, Geochronology of Tertiary igneous rocks, eastern Basin and Range province, western Utah, eastern Nevada, and vicinity, U.S.A.: Geochim. et Cosmochim. Acta, v. 34, no. 2, p. 203-232.

Cross, C. Whitman, 1886. On the occurrence of topaz and garnet in lithophysae of rhyolite: Am. Jour. Sci., 3d ser., v. 31, p. $432-438$.

Erickson, M. P., 1963, Volcanic geology of western Juab County, Utah, in Sharp, B. J., and Williams, N .C., eds., Beryllium and uranium mineralization in western Juab County, Utah: Utah Geol. Soc. Guidebook to the Geology of Utah, no. 17 , p. 23-25.

Evernden, J. F., Savage, D. E., Curtis, G. H., and James, G. T., 1964, Potassium-argon dates and the Cenozoic mammalian chronology of North America: Am. Jour. Sci., v. 262 ,no. 1, p. 145-198.
Fleischer, R. L., Price, P. B., and Walker, R. M., 1965a, Tracks of charged particles in solids: Science, v. 149 , no. 3682 , p. 383-393.

- 1965b, Effects of temperature, pressure, and ionization on the formation and stability of fission tracks in minerals and glasses: Jour. Geophys. Research, v. 70, no. 6, p. 14971502.

Griffitts, W. R., 1964, Beryllium, in Mineral and water resources of Utah: Utah Geol. and Mineralog. Survey Bull. 73, p. 71-75.

Jaffe, H .W., Gottfried, David, Waring, C. L., and Worthing, H. IV., 1959, Lead-alpha age determinations of accessory minerals of igneous rocks $(1953-57)$ : U.S. Geol. Survey Bull. 1097-B, p. 65-148.

Leedom, S. H., 1974, Little Drum Mountains, an Early Tertiary shoshonitic volcanic center in Millard County, Utah : Brigham Young Univ. Geology Studies, v. 21, p. 73-108.

Lindsey, D. A., 1975, Mineralization halos and diagenesis in waterlaid tuff of the Thomas Range, Utah: U.S. Geol. Survey Prof. Paper 818-B. (In press.)

Lindsey, D. A., Ganow, Harold, and Mountjoy, Wayne, 1973, Hydrothermal alteration associated with beryllium deposits at Spor Mountain, Utah: U.S. Geol. Survey Prof. Paper 818-A, $20 \mathrm{p}$.

McKee, E. H., Noble, D. C., and Silberman, M. L., 1970, Middle Miocene hiatus in volcanic activity in the Great Basin area of the western United States: Earth and Planetary Sci. Letters, v. 8, p. 93-96.

Naeser, C. W., 1967, The use of apatite and sphene for fission track age determinations: Geol. Soc. America Bull., v. 78 , no. 12 , p. $1523-1526$.

1969, Etching fission tracks in zircons: Science, v. 165, no. 3891 , p. 388.

Naeser, C. W., and Dodge, F. C. W., 1969, Fission-track ages of accessory minerals from granitic rocks of the central Sierra Nevada batholith, California: Geol. Soc. America Bull., v. 80, no. 11, p. 2201-2211.

Naeser, C. W., and Faul, H., 1969, Fission-track annealing in apatite and sphene: Jour. Geophys. Research, v. 74, no. 2, p. $705-710$.

Odekirk, J. R., 1970, Desert Mountain granite, in Whelan, J. A., compiler, Radioactive and isotopic age determinations of Utah rocks: Utah Geol. and Mineralog. Survey Bull. 81, p. 33.

Park, G. M., 1970, Volcanics, Thomas Range, in Whelan, J. A., compiler, Radioactive and isotopic age determinations of Utah rocks: Utah Geol. and Mineralog. Survey Bull. 81, p. 23.

Shawe, D .R., 1972, Reconnaissance geology and mineral potential of Thomas, Keg, and Desert Calderas, central Juab County, Utah, in Geological Survey research 1972: U.S. Geol. Survey Prof. Paper 800-B, p. B67-B77.

Staatz, M. H., and Carr, W. J., 1964, Geology and mineral deposits of the Thomas and Dugway Ranges, Juab and Tooele Counties, Utah: U.S. Geol. Survey Prof. Paper 415, $188 \mathrm{p}$.

Staatz, M. H., and Griffitts, W. R., 1961, Beryllium-bearing tuff in the Thomas Range, Juab County, Utah: Econ. Geology, v. 56, no. 5, p. 941-950. 


\title{
THE OLIGOCENE VOLCANIC CENTER AT EUREKA, NEVADA
}

\author{
By M. C. BLAKE, Jr., ${ }^{1}$ E. H. McKEE, ${ }^{1}$ RICHARD F. MARVIN, ${ }^{2}$ \\ MILES L. SILBERMAN, ${ }^{1}$ and THOMAS B. NOLAN, ${ }^{3}$ \\ Menlo Park, Calif., ${ }^{1}$ Denver, Colo., ${ }^{2}$ Reston, Va. ${ }^{3}$
}

\begin{abstract}
A volcanic center covering an area of about 80 $\mathrm{km}^{2}$ near Eureka, Nev., and active in the early Oligocene, is characterized by rhyolitic, rhyodacitic, and andesitic pyroclastic rocks, lava flows, and shallow intrusive bodies. These rocks were emplaced as intertonguing and interpenetrative units during a 5-m.y. interval; most of the volcanism was in the last 3 million years of this period ( 36 to 33 m.y. ago).
\end{abstract}

Detailed mapping of Cenozoic volcanic rocks near Eureka, Nev., indicates the existence of a complex volcanic field of middle Tertiary age. The rocks consist of a succession of intertonguing and interpenetrative andesite flows and hypabyssal bodies and rhyolite domes, flows, and pyroclastic deposits. The volcanic field was active for about 5 m.y., but most of the rocks were emplaced during a 3-m.y. interval about 36 to 33 m.y. ago (early Oligocene). This volcanic complex is similar to others in the Western United States in size, variety of rock types, eruptive duration, and history.

Ash-flow sheets of about the same age but erupted from sites far removed from Eureka spread across the area and are interbedded with the local flows. They are not a part of the Eureka volcanic center. Only rocks from the Eureka center are discussed in this report. It does not consider the genesis of the volcanic rocks nor does it compare them with rocks of the same age elsewhere in eastern Nevada.

This study draws principally on the geologic mapping of the Eureka quadrangle by Nolan, Merriam, and Brew (1971) and the map of the Pinto Summit quadrangle by Nolan, Merriam, and Blake (1974). Regions to the south and east were mapped by Hose and Blake (1970) for the geologic map of White Pine County. Potassium-argon dating was done by R. F. Marvin, E. H. McKee, and M. L. Silberman in conjunction with the field studies. We are indebted to $R$. L. Smith and C. A. Anderson who visited the area and aided in the interpretation of the volcanic history.

\section{GEOLOGIC SETTING}

Cenozoic rocks in the Eureka area lie unconformably on, or intrude, a variety of faulted and folded Paleo- zoic and Mesozoic rocks, the youngest of which are Cretaceous.

The oldest Tertiary rocks from the Eureka volcanic center are flows, breccias, and shallow intrusive bodies that make up the Ratto Spring Rhyodacite (Nolan and others, 1974). These rocks are confined to a narrow, north-trending belt in the western part of the area (fig. 1).

Unconformably overlying the Ratto Spring Rhyodacite is a complex unit of rhyolitic composition, the Pinto Peak Rhyolite, comprising several lithologic types that include the Pinto Basin and Sierra Springs Tuff Members and several unnamed members (Nolan and others, 1974). The most distinctive and widespread unit is the Pinto Basin Tuff Member, which consists of white to gray air-fall vitric-crystal tuff, lithic pumice breccia, and tuffaceous sandstone. This tuff crops out over an area of at least $1,600 \mathrm{~km}^{2}$ and has a maximum thickness of about $150 \mathrm{~m}$. The tuff was erupted from a number of vents alined in a northerly direction that lie a short distance east of the older Ratto Spring Rhyodacite. These vents were filled by typical endogenous and exogenous domes, each circumscribed by a broad apron of fine-grained tuff that grades toward the vent into a coarse breccia of pumice and intrusive rhyolite. The vent breccias encircle domes of porphyritic rhyolite from which lavas locally spread over the pumice breccias and pyroclastic apron. Domes at the south end of the belt have pronounced laminated flow structure and contain a different phenocryst population from the domes at the north end.

In the southwestern part of the Pinto Summit quadrangle (lat $39^{\circ} 15^{\prime}-39^{\circ} 30^{\prime} \mathrm{N}$.; long $115^{\circ} 45^{\prime}-116^{\circ} 00^{\prime} \mathrm{W}$.) and farther west is a rhyodacitic welded ash-flow tuff called the Sierra Springs Tuff Member. This tuff consists of three cooling units with a combined maximum thickness of about $200 \mathrm{~m}$ and an estimated outcrop area of about $130 \mathrm{~km}^{2}$. The lower two cooling units in this ash-flow sheet are very similar; the upper one is more mafic. In places the Sierra Springs overlies the 


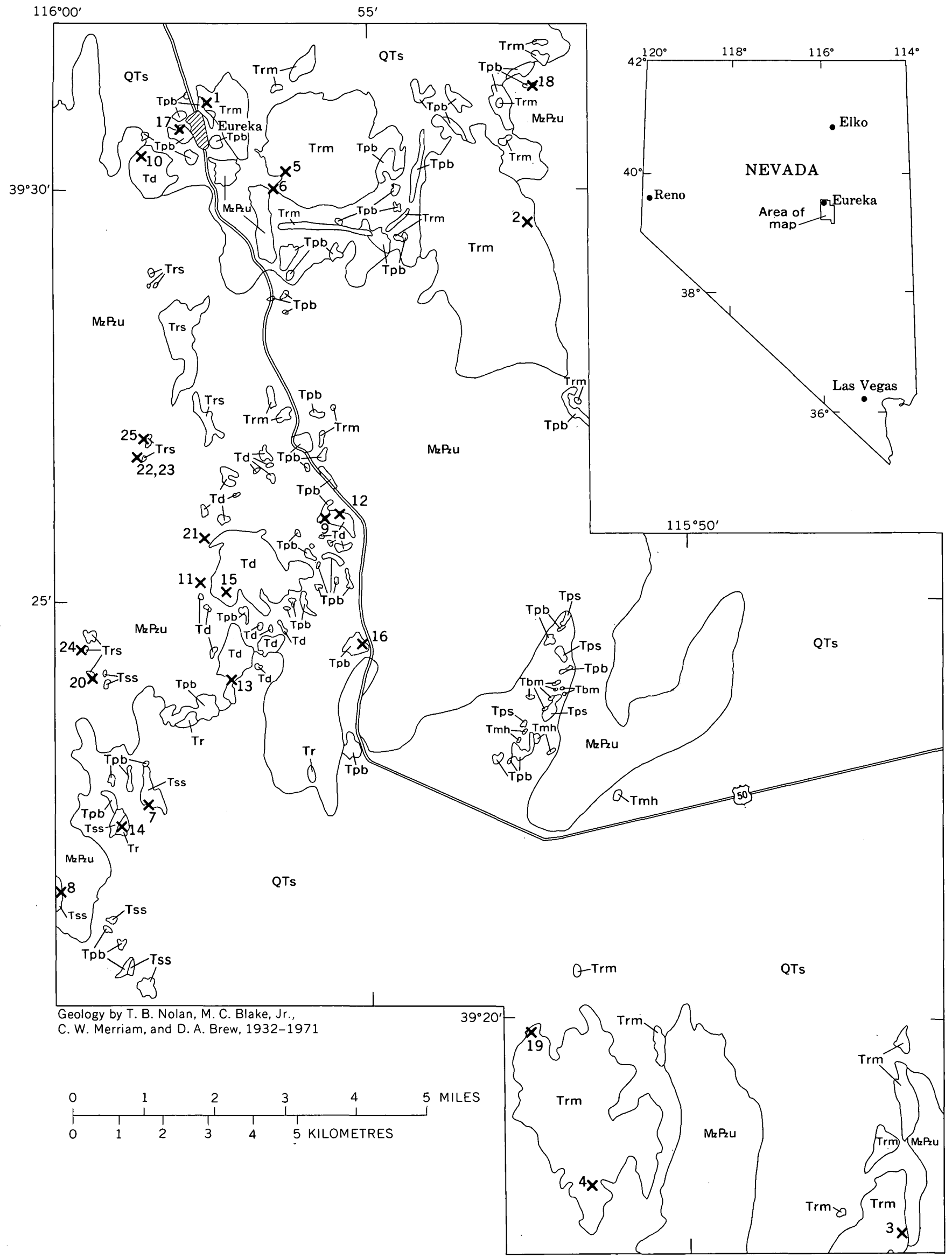




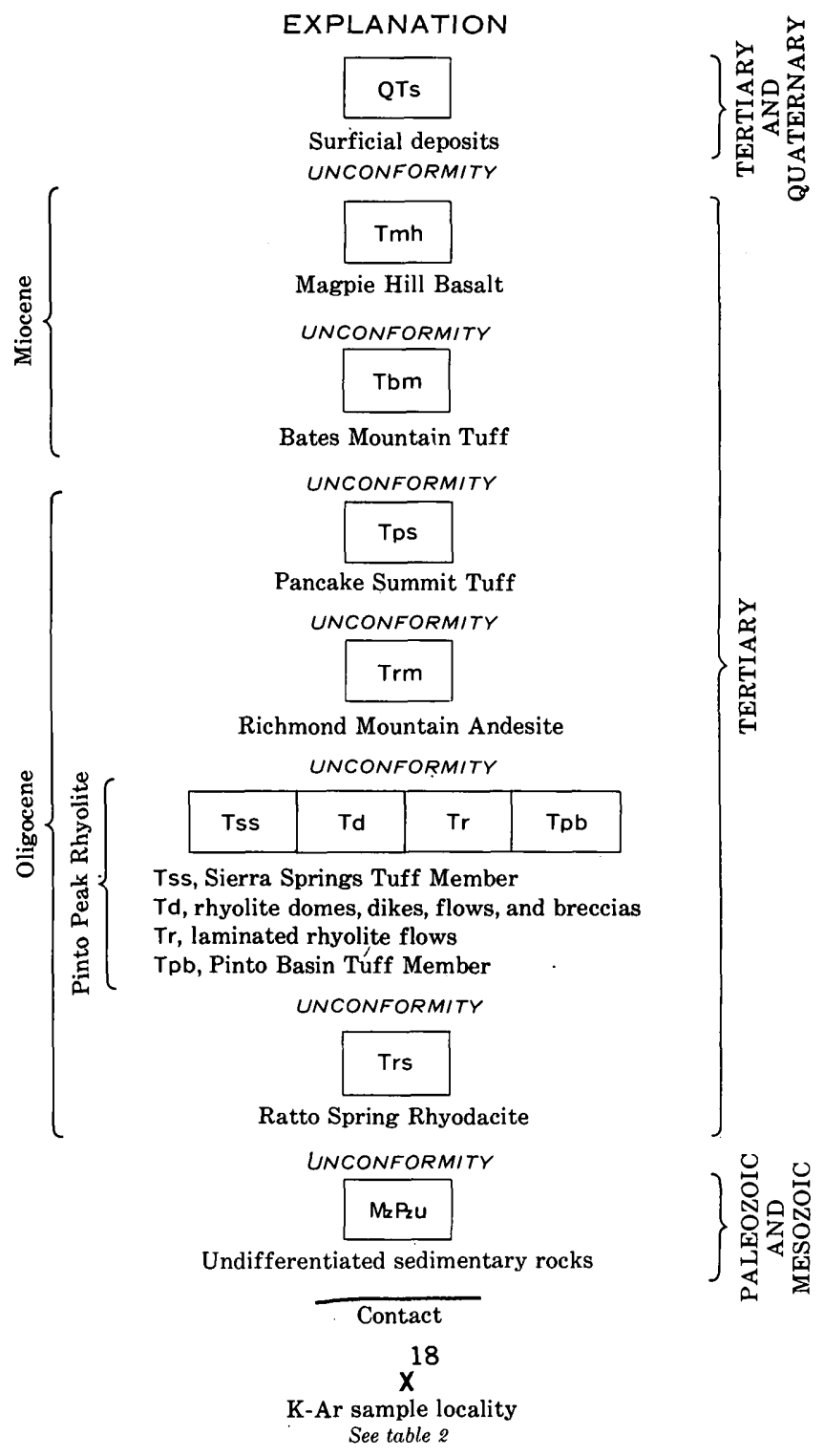

Figure 1.-Geologic map of the Eureka area outlining the Oligocene volcanic rocks of the Eureka volcanic center.

Pinto Basin 'Tuff Member, and at one place the Sierra Springs is intruded by a laminated Pinto Peak rhyolite dome. Fourteen $\mathrm{K}$-Ar ages from a variety of Pinto Peak rhyolitic rocks and Sierra Springs tuff show complete overlap and average about $35 \mathrm{~m} . \mathrm{y}$.

The Richmond Mountain Andesite (Nolan and others, 1974) contains the youngest rocks of the Oligocene Eureka volcanic center. This andesite generally overlies or intrudes the more silicic rocks of the volcanic field, but fragmental debris of andesitic composition, a fairly common constituent of some of the pyroclastic rhyolite units, as in the Pinto Basin Tuff Member at Black Point (K-Ar locality 19, fig. 1), indicates that some andesite is older. Potassium-argon ages on the Richmond Mountain Andesite are the same as those of the rhyodacites and rhyolites, thus verifying the contemporaneous nature of most of the volcanism in the area.

\section{PETROLOGY}

Ratto Spring Rhyodacite.-The flows and intrusive rocks of this formation are all porphyritic, containing about 30 to 40 percent phenocrysts of hornblende, plagioclase, biotite, and scarce quartz in a fine-grained, generally flow-banded groundmass that is gray to light brown in fresh specimens but reddish brown in weathered specimens. Other less common types are darkgray to black autobrecciated vitrophyre and thin, water-laid tuffaceous sandstone.

Pinto Peak Rhyolite.-The Pinto Basin Tuff Member, which is the most widespread rhyolitic unit, consists of vitric-crystal tuff, lithic pumice breccia, and tuffaceous sedimentary rocks. The overlying porphyritic flow and intrusive rocks are white to gray with phenocrysts of biotite, sanidine, quartz, and some plagioclase in a fine-grained flow-banded groundmass. Small pink garnets are a common and distinctive accessory mineral. The distinctively laminated rhyolite in the southern outcrops of the Pinto Peak Rhyolite differs from the northern ones by having fewer total phenocrysts of biotite, plagioclase, and scarce quartz; sanidine is not present.

The lower two cooling units in the Sierra Springs Tuff Member are similar in compacting and welding profiles as well as in lithology and show the typical upward gradation from a nonwelded base through a eutaxitic densely welded zone into a nonwelded top. The average phenocryst population, which makes up about 15 percent of the rock, includes about 60 percent plagioclase, 20 percent mafic minerals (mostly biotite with some hornblende, augite, hypersthene, and magnetite), 15 percent quartz, and a few percent sanidine. Four chemical analyses of samples collected from the densely welded parts of both cooling units are listed in table 1 (last four columns), and normative minerals from the analyses are plotted on a variety of triangular diagrams (fig. 2) to illustrate the chemical characteristics of these ash flows.

The upper ash flow is more mafic than the lower ones and is characterized by a glassy eutaxite near its base. This member contains abundant phenocrysts of pyroxene that distinguish it from the lower members. A chemical analysis (PS66B-59, table 1) shows that it contains less silica and more total iron, magnesium, and calcium than the underlying units.

Richmond Mountain Andesite.-Rocks called Richmond Mountain Andesite are generally darker than 


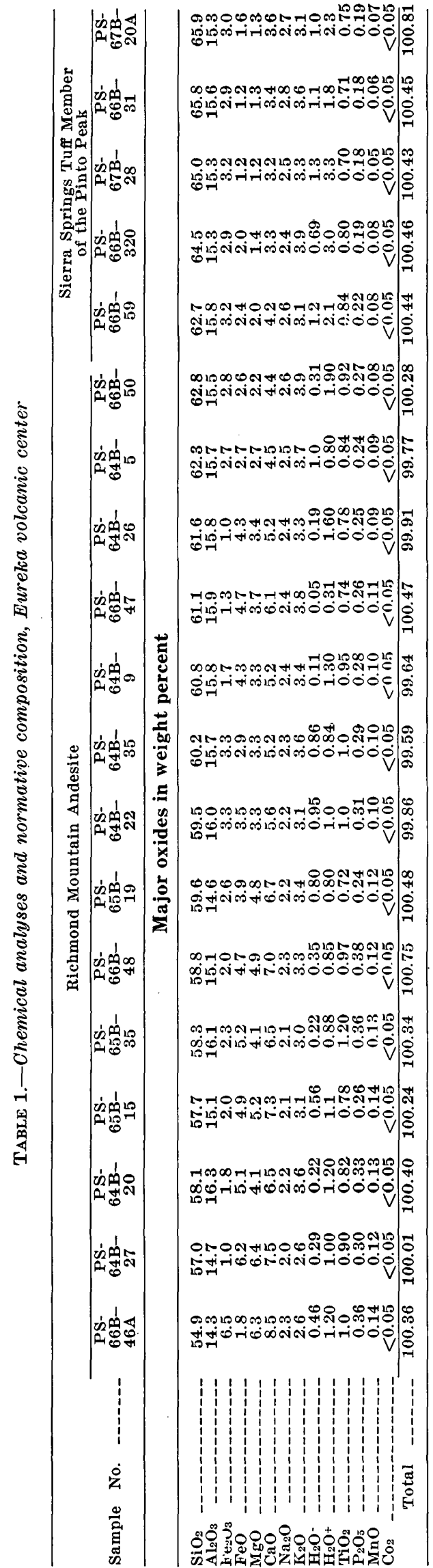

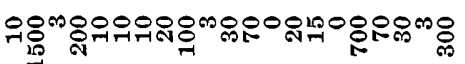

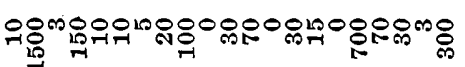

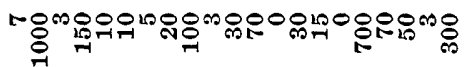

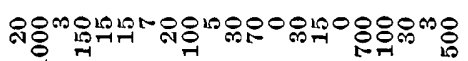

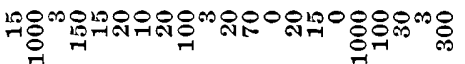

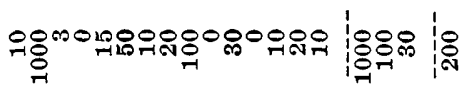

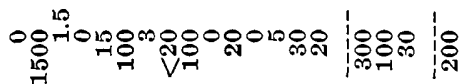

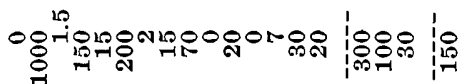
ค윰 윰ำ ○ 암ำ ○ᄋำ 욤ำ

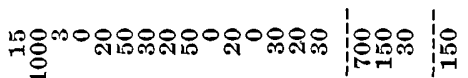

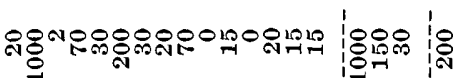
음 ํํㅇำ

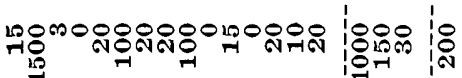

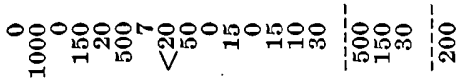
믐임

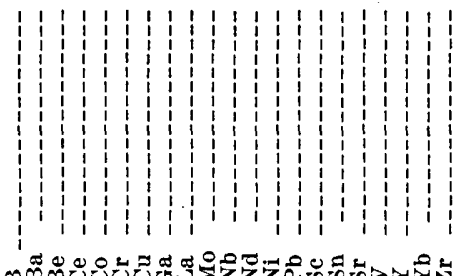

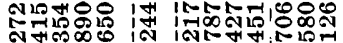

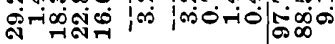

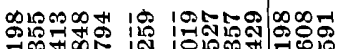
专

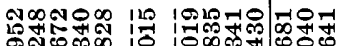

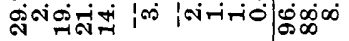

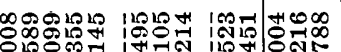

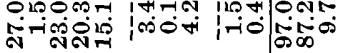

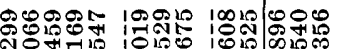

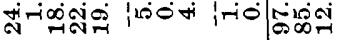

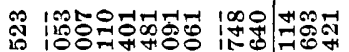

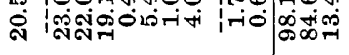

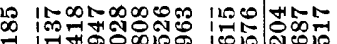

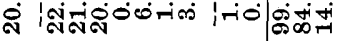

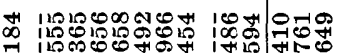

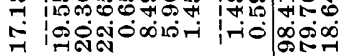

- 1-

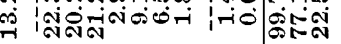

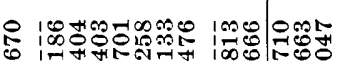
-

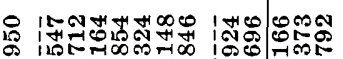
त

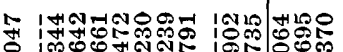
को

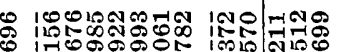
虽

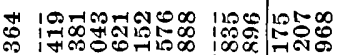

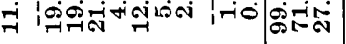
颌

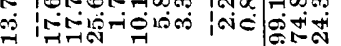

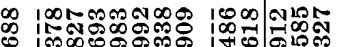
:

잉

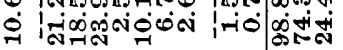

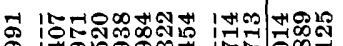

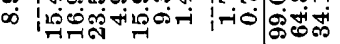

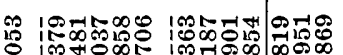

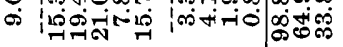
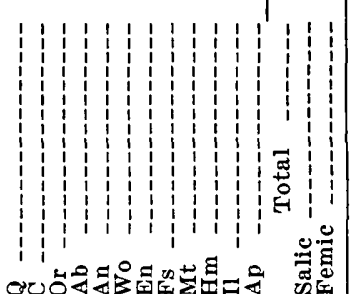


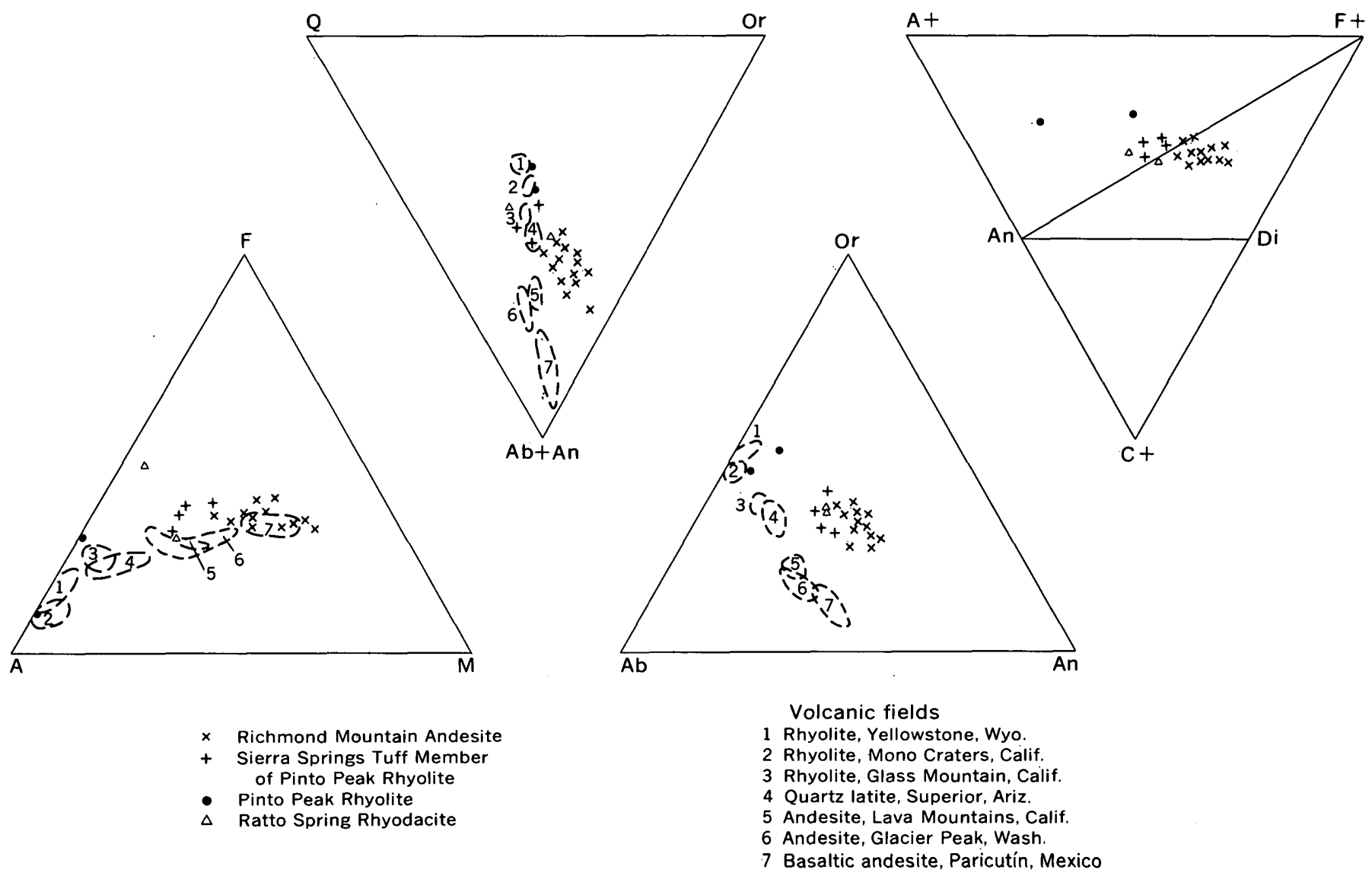

Figure 2.-Triangular diagram showing composition of rocks of the Oligocene volcanic center, Eureka, Nev., compared with the composition of rocks of volcanic fields (dashed areas) of the Western United States and Mexico. All oxides recalculated minus $\mathrm{H}_{2} \mathrm{O}$ and $\mathrm{CO}_{2}$, and $\mathrm{Fe}_{2} \mathrm{O}_{3}$ plus $\mathrm{FeO}$ is total $\mathrm{Fe}$ in $\mathrm{FeO}$.

the rhyolitic and rhyodacitic rocks of the Eureka volcanic center and are mapped on this basis. These darker rocks are also petrologically and chemically distinct although they exhibit a wide variation in texture, mineralogy, and chemistry. The most mafic varieties, including all the dikes, are massive and subaphanitic with a few small $(\leqslant 1 \mathrm{~mm})$ pyroxene or plagioclase phenocrysts. These rocks are usually very dark gray but in places are oxidized to brick red. They have a pilotaxitic or trachytic texture defined by alinement of microphenocrysts of hypersthene, augite, and plagioclase in a groundmass which is either brown glass or a fine-grained intergrowth of sanidine, cristobalite, and tridymite. The most siliceous varieties of the Richmond Mountain Andesite are characterized by more abundant (25 percent) and larger (1-3 mm) phenocrysts of hypersthene, augite, and plagioclase, as well as some hornblende and biotite. Fourteen chemical analyses including most of the lithologic types of the Richmond Mountain Andesite are listed in table 1, and normative mineral plots are shown in figure 2. This rock is a high-potassium andesite in the usage of Taylor $(1969$, p. 45$)$ at the Andesite Conference of 1968.

\section{CHEMISTRY}

Chemical analyses and CIPW norms for 19 samples from the Eureka volcanic center are listed in table 1. These include 14 for the Richmond Mountain Andesite, five for the Sierra Springs Tuff Member. These analyses plus four analyses of the Pinto Peak Rhyolite and Ratto Spring Rhyodacite listed by Hague (1892 analyses $2-4,6$, p. 264) in his study of the Eureka district were used in the triangular diagrams (fig. 2) and silica variation diagrams (fig. 3 ).

In order to compare the Eureka rocks with those of other well-known petrographic provinces in the western Cordillera, we have included the rocks of several volcanic fields from western North America on three of the triangular diagrams. These are (1) rhyolite from Yellowstone, Wyo. (Hamilton, 1963, 11 analyses), (2) rhyolite from Mono Craters, Calif. (Loney, 1968, eight analyses), (3) rhyolite from Glass Mountains, Calif. (Anderson, 1933, eight analyses), (4) 

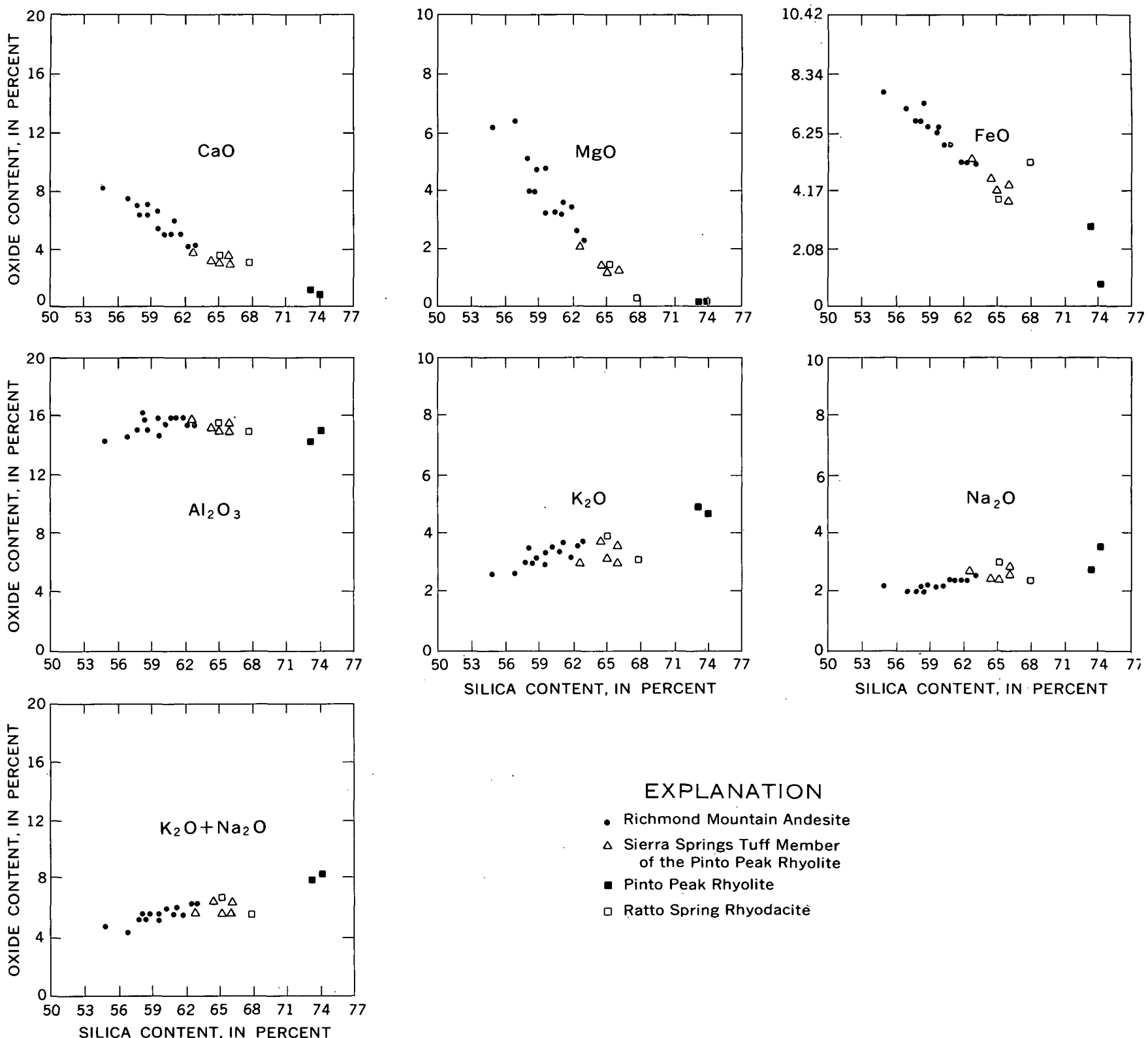

\section{EXPLANATION}

- Richmond Mountain Andesite

$\Delta$ Sierra Springs Tuff Member of the Pinto Peak Rhyolite

- Pinto Peak Rhyolite

口 Ratto Spring Rhyodacite

Figure 3.-Diagrams showing variation between silica and other major oxides in rocks from the Oligocene Eureka volcanic center.

quartz latite from Superior, Ariz. (Peterson, 1961, 12 analyses), (5) andesite from Lava Mountains, Calif. (Smith, 1964, 10 analyses), (6) andesite from Glacier Peak, Wash. (Tabor and Crowder, 1969), and (7) basaltic andesite from Paricutín, Mexico (Wilcox, 1954, 22 analyses). The high-potassium character of the Eureka rocks, particularly the andesites, compared with that of the other volcanic suites, is clearly shown on the orthoclase-albite-anorthite and the quartz-albite plus anorthite-orthoclase diagrams (fig. 2). The trace-element contents of the rocks, like some of the major oxides, show differences from most of the listed andesites and rhyolites, mainly in having much higher $\mathrm{Ba}, \mathrm{Be}, \mathrm{La}, \mathrm{Nb}$, and $\mathrm{Y}$, and lower $\mathrm{Ni}$.

\section{AGE}

Analytical procedure.-The K-Ar analyses reported here were done in the laboratories of the U.S. Geological Survey in Menlo Park, Calif., and Denver, Colo., by McKee, Silberman, and Marvin. Analysis was by standard isotope dilution techniques (see Dalrymple and Lanphere, 1969) on Neir-type $60^{\circ}$ sector, 6-in. mass spectrometers or on a Reynolds-type $60^{\circ}$-sector, $41 / 2$-in. mass spectrometer, both types op- 
erated in the static mode. Potassium. was determined by flame photometry using a lithium internal standard. The estimated analytical uncertainties of the $\mathbf{K}-\mathbf{A r}$ ages are indicated at one standard deviation and are based on statistical analysis of replicate argon determinations and repeated potassium determinations on a large number of samples analyzed during the course of this study (McKee and Silberman, 1970). The KAr ages for each unit are listed in table 2 and shown graphically in figure 4. Locations are plotted on the geologic map (fig. 1).

Ratto Spring Rhyodacite.-Six samples of the Ratto Spring Rhyodacite yielded ages from $38.0 \pm 0.8$ to $35.3 \pm 0.7 \mathrm{~m} . \mathrm{y}$. (table 2$)$. The oldest date $(38.0 \pm 0.8$ m.y.) and the youngest $(35.3 \pm 0.7 \mathrm{m.y.}$ ) do not overlap within their analytical uncertainty, suggesting that these rocks are of different age. Considering the six samples that were dated from different places, we suggest that eruption of Ratto Spring Rhyodacite may have taken place during a period of about $3 \mathrm{~m} . \mathrm{y}$.

Pinto Peak Rhyolite.-Four samples of the Pinto

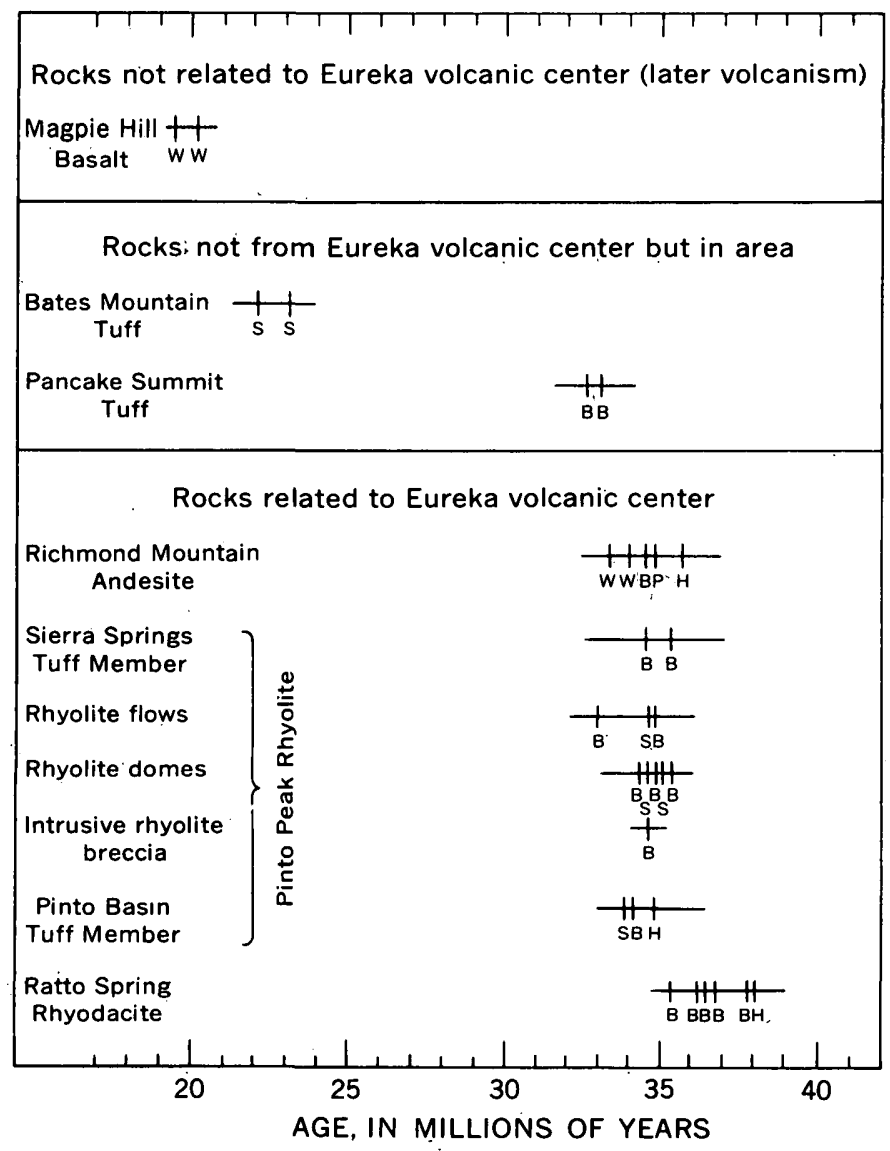

Frgure 4.-Potassium-argon ages of minerals and rocks from the Tertiary volcanic center near Eureka, Nev. Length of horizontal bar is the analytical uncertainty. B, biotite; $H$, hornblende; $P$, plagioclase; $S$, sanidine; and $W$, whole rock.
'TABLE 2.-Summary of $\mathrm{K}-\mathrm{Ar}$, ages of volcanic rocks in the Eureka area, Nevada

\begin{tabular}{|c|c|c|c|c|c|c|}
\hline Map unit & Description & $\begin{array}{l}\text { Loce } \\
\text { ity N } \\
\text { in } \\
\text { fig. }\end{array}$ & $\begin{array}{l}\text { Sam- } \\
\text { ple } \\
\text { No. }\end{array}$ & Mineral & Age & $\begin{array}{c}\text { Refer- } \\
\text { ence } \\
\text { sampl } \\
\text { No.1 }\end{array}$ \\
\hline \multirow[t]{2}{*}{ Trm } & $\begin{array}{l}\text { Richmond } \\
\text { Mountain }\end{array}$ & 1 & E-12 & Whole rock & $33.2 \pm 1.0$ & 120 \\
\hline & & $\begin{array}{l}2 \\
3 \\
4 \\
5 \\
6\end{array}$ & $\begin{array}{l}\text { E-8 } \\
\text { E-21 } \\
\text { PS658-35 } \\
\text { PS886 } \\
\text { HG434 }\end{array}$ & $\begin{array}{l}\text { Biotite } \\
\text { Plagioclase } \\
\text { Hornblende } \\
\text { Plagioclase }\end{array}$ & $\begin{array}{l}33.8 \pm 1.0 \\
34.3 \pm 0.7 \\
34.7 \pm 1.9 \\
35.6 \pm 1.3 \\
39.8 \pm 1.6\end{array}$ & $\begin{array}{l}114 \\
127 \\
126 \\
113\end{array}$ \\
\hline Tss & $\begin{array}{l}\text { Sierra } \\
\text { Springs } \\
\text { Tuff } \\
\text { Member of } \\
\text { Pinto Peak } \\
\text { Rhyolite. }\end{array}$ & 7 & PS66B-31 & Biotite & $\begin{array}{r}39.8 \pm 1.6 \\
34.3 \pm 1.9\end{array}$ & $\overline{100}$ \\
\hline \multirow[t]{3}{*}{$T d$} & Rhyolite & $\begin{array}{l}8 \\
9\end{array}$ & $\begin{array}{l}\text { PS66B-59 } \\
\text { PS64B-18 }\end{array}$ & $\begin{array}{l}\text { Hornblende } \\
\text { Biotite }\end{array}$ & $\begin{array}{l}35.3 \pm 1.9 \\
35.0 \pm 0.8\end{array}$ & $\begin{array}{r}98 \\
110\end{array}$ \\
\hline & & $\begin{array}{l}10 \\
11 \\
12 \\
12\end{array}$ & $\begin{array}{l}\text { E64B3 } \\
\mathrm{E}-14 \\
\mathrm{E}-19 \\
--\mathrm{do}--\end{array}$ & $\begin{array}{l}\text { Sanidine } \\
\text { Biotite } \\
\text { Sanidine }\end{array}$ & $\begin{array}{l}34.5 \pm 1.4 \\
34.6 \pm 0.7 \\
35.5 \pm 0.7 \\
35.0 \pm 0.7\end{array}$ & $\begin{array}{l}117 \\
105 \\
107 \\
107\end{array}$ \\
\hline & $\begin{array}{c}\text { Intrusive } \\
\text { rhyolite } \\
\text { breccia. }\end{array}$ & 13 & $\mathrm{E}-13$ & Biotite & $34.7 \pm 0.7$ & 101 \\
\hline \multirow[t]{2}{*}{$\operatorname{Tr} \ldots-\cdots$} & $\begin{array}{l}\text { Laminated } \\
\text { rhyolite } \\
\text { flows. }\end{array}$ & 14 & PS66B-55 & --do_- & $34.8 \pm 1.4$ & 99 \\
\hline & $\begin{array}{l}\text { Rhyolite } \\
\text { flows }\end{array}$ & 15 & E-15 & $--d o \_-$ & $33.0 \pm 1.0$ & 106 \\
\hline \multirow[t]{2}{*}{ Tpb } & $\begin{array}{l}\text { Pinto. Basin } \\
\text { Tuff } \\
\text { Member of } \\
\text { Pinto Peak } \\
\text { Rhyolite. }\end{array}$ & $\begin{array}{l}15 \\
16\end{array}$ & $\overline{\mathrm{P}}-\mathrm{do} 66 \overline{\mathrm{B}}-81$ & $\begin{array}{l}\text { Sanidine } \\
\text { Blotite }\end{array}$ & $\begin{array}{l}34.7 \pm 0.7 \\
34.6 \pm 1.9\end{array}$ & $\begin{array}{l}106 \\
102\end{array}$ \\
\hline & Ratto & $\begin{array}{l}17 \\
18 \\
19 \\
20\end{array}$ & $\begin{array}{l}\text { E-32 } \\
\mathrm{E}-27 \\
\mathrm{PS} 683 \\
\mathrm{E}-29\end{array}$ & $\begin{array}{l}\text { Sanidine } \\
\text { Biotite } \\
\text { Hornblende } \\
\text { Biotite }\end{array}$ & $\begin{array}{l}33.7 \pm 0.7 \\
33.9 \pm 0.7 \\
34.7 \pm 1.3 \\
35.3 \pm 0.7\end{array}$ & $\begin{array}{l}119 \\
115 \\
125 \\
103\end{array}$ \\
\hline Trs & & $\begin{array}{l}21 \\
22 \\
23 \\
24 \\
25\end{array}$ & $\begin{array}{l}\text { E-16 } \\
\text { PS682 } \\
\text { PS681 } \\
\text { PS685 } \\
\text { PS64B-17 }\end{array}$ & 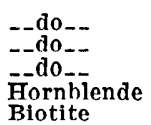 & $\begin{array}{l}36.2 \pm 0.7 \\
36.4 \pm 1.3 \\
36.8 \pm 1.3 \\
37.8 \pm 1.3 \\
38.0 \pm 0.8\end{array}$ & $\begin{array}{l}111 \\
116 \\
112 \\
104 \\
109\end{array}$ \\
\hline
\end{tabular}

1 Samples reported by McKee, Silberman, Marvin, and Obradovich (1971).

Basin Tuff Member, the most widespread member in the Pinto Peak Rhyolite, were dated (table 2): the ages range from $34.7 \pm 1.3$ to $33.7 \pm 0.7$ m.y. and overlap within their analytical uncertainty. The four dates taken as a group and compared with the six dates of the Ratto Spring Rhyodacite suggest that the Pinto Basin is younger. Geologic relations clearly show this to be true. A sample of rhyolite in the Pinto Peak Rhyolite yielded an average age of $33.9 \mathrm{~m} . \mathrm{y}$. (average of the mineral-pair ages of 33.0 and 34.7 m.y.), and a second sample, $34.8 \pm 1.4$ m.y. Five samples of porphyritic rhyolite from various domes give ages ranging from $35.5 \pm 0.7$ to $34.5 \pm 1.4$ m.y. A single sample of intrusive rhyolite breccia from one dome gave an age of $34.7 \pm 0.7 \mathrm{~m}$.y. The age range of 33.1 to $35.5 \mathrm{~m}$.y. from the rhyolite dome complexes suggests that these domes were being emplaced during a period of time of about 2 m.y. The age of emplacement of an individual dome and its pyroclastic products would have been considerably less.

Two samples of tuff from the Sierra Springs Tuff Member gave ages of $35.3 \pm 1.9$ and $34.3 \pm 1.9$ m.y. Richmond Mountain Andesite.-Six samples of var- 
ied lithology from this formation yield $\mathrm{K}-\mathrm{Ar}$ ages from $39.8 \pm 1.6$ to $33.2 \pm 1.0$ m.y. The $39.8 \pm 1.6-$ m.y. age is significantly older than the other five samples, which average $34.5 \mathrm{~m} . \mathrm{y}$. and which overlie rocks that yield ages of about $35 \mathrm{~m} . \mathrm{y}$, and is not considered here to be a geologically significant age for the formation. The age data (excluding the 39.8-m.y. age) suggest that the Richmond Mountain Andesite volcanism spanned a period of about 2 to 3 m.y. Geologic relations indicate, however, that most of the andesites were emplaced during the younger part of this suggested age span: in most places the andesites overlie or intrude more silicic rocks with $34-$ to 36 -m.y. ages.

\section{REFERENCES CITED}

Anderson, C. A., 1933, Volcanic history of Glass Mountain, northern California: Am. Jour. Sci. v., 26, p. 485-506.

Dalrymple, G. B., and Lanphere, M. A., 1969, Potassium-argon dating, principles, techniques and applications to geochronology : San Francisco, W. H. Freeman and Co., 258 p.

Hague, Arnold, 1892, Geology of the Eureka district, Nevada: U.S. Geol. Survey Mon. 20, 419 p.

Hamilton, Warren, 1963, Petrology of rhyolite and basalt, northwestern Yellowstone Plateau, in Geological Survey research, 1963: U.S. Geol. Survey Prof. Paper 475-C, p. C78-C81.

Hose, R. K., and Blake, M. C., Jr., 1970 Geologic map of White Pine County, Nevada: U.S. Geol. Survey open-file map, scale 1:250,000.
Loney, R. A., 1968, Flow structure of the southern Coulee, Mono Craters, California-a pumiceous rhyolite flow: Geol. Soc. America Mem. 116, p. 415-440.

McKee, E. H., and Silberman, M. S., 1970, Geochronology of Tertiary igneous rocks in central Nevada: Geol. Soc. America Bull., v. 81, p. 2317-2328.

McKee, E. H., Silberman, M. L., Marvin, R. E., and Obradovich, J. D., 1971, A summary of radiometric ages of Tertiary volcanic rocks in Nevada and eastern California ; Part Icentral Nevada: Isochron/West, no. 2, p. 21-42.

Nolan, T. B., Merriam, C. W., and Blake, M. C., Jr., 1974, Geology of the Pinto Summit quadrangle, Eureka and White Pine Counties, Nevada: U.S. Geol. Survey misc. Geol. Inv. Map I-793.

Nolan, T .B., Merriam, C. W., and Brew, D. A. 1971, Geology of the Eureka quadrangle, Eureka and White Pine Counties, Nevada: U.S. Geol. Survey Misc. Geol. Inv. Map I-612 with text, $8 \mathrm{p}$.

Peterson, D. W. 1961, Origin of the dacite near Superior and Globe, Arizona: Stanford, Calif., Stanford Univ. Ph. D. thesis, $130 \mathrm{p}$.

Smith, G. I., 1964, Geology and volcanic petrology of the Lava Mountains, San Bernardino County, California: U.S. Geol. Survey Prof. Paper 457, 89 p.

Tabor, R. W., and Crowder, D. F., 1969, On batholiths and volcanoes-intrusion and eruption of late Cenozoic magmas in the Glacier Peak area, North Cascades, Washington: U.S. Geol. Survey Prof. Paper 604, 67 p.

Taylor, S. R., 1969, Trace element chemistry of andesites and associated calc-alkaline rocks : Andesite Conf. Proc., Internat. Upper Mantle Project Sci. Rept. 16, Bull. 65, p. 43-64.

Wilcox, R. E., 1954, Petrology of Parícutin volcano, Mexico: U.S. Geol. Survey Bull. 965-C, p. 281-353. 


\title{
GEOMORPHIC EVIDENCE FOR LATE HOLOCENE TILTING IN SOUTHERN SAN MATEO COUNTY, CALIFORNIA
}

\author{
By DAVID P. ADAM, Menlo Park, Calif.
}

\begin{abstract}
Relations between the stream channels and the alluvial deposits along Bradley Creek and the lower part of Butano Creek suggest that the area has been tilted very recently, and localized swampy conditions supply additional supporting evidence. Radiocarbon dates show that some of the valley alluvium along Butano Creek was deposited no more than 750-800 $\mathrm{yr}$ ago, and tilting must have occurred since that time.
\end{abstract}

Areas along the Pacific coast in southwestern San Mateo County, Calif., south of San Francisco, are presently being considered for development. Prominent elevated beach terraces indicate that Pleistocene uplift occurred along the coast in nearby areas (Bradley, 1957, 1958, 1965; Jack, 1968; Smith, 1960 ; Palmer, 1967; Bradley and Addicott, 1968), and LaJoie, Weber, and Tinsley (1972) demonstrated that, in the area described in this report, the terraces have been tilted as well as uplifted. The observations reported here indicate that, at least in the vicinity of Pescadero, this tilting is still active. The evidence presented suggests no particular cause for the tilting, but it may be related to movement on the San Gregorio fault, a branch of the San Andreas fault system that passes through the area (Cooper, 1971, and fig. 1).

\section{DESCRIPTION OF AREA}

The drainages of Butano Creek and Bradley Creek cross the San Gregorio fault zone in southwestern San Mateo County, Calif. (fig. 1). Both valley floors are alluviated for several kilometres above their mouths. The alluviation is at least partly a response to the rise of sea level to its present position during the Holocene and is thus probably not older than $5000-6000 \mathrm{yr}$. No further information is available for the alluvium of Bradley Creek but two radiocarbon dates from Butano Creek deposits demonstrate that alluviation in that valley was still active between 750 and $800 \mathrm{yr}$ ago (see below). A young age for the deposits is also indicated by poorly developed soils that lack B horizons. Older stream terrace deposits, such as those found along Pescadero Creek, have soils that include B horizons (Soil Conservation Service, 1961).
The paths followed by the channels of the two creeks and the pattern of stream incision as they cross their alluviated valleys suggest that the depositional environment of the alluvium has been altered by local or regional tilting that forced the stream channels to the west sides of their valleys. The gradient of Butano Creek, which flows northward, was increased and caused incision, whereas the gradient of Bradley Creek, which flows in the opposite direction, decreased. The tilting therefore had northerly and westerly components toward the ocean.

\section{BUTANO AND LITTLE BUTANO CREEK}

Along reach $A-B$ (Little Butano Creek) and along reaches $C-D$ and $G-H$ (Butano Creek), the stream channel follows the extreme west edge of the alluvial fill as the stream flows northward (fig. 2). If the path of the stream had been controlled only by fluvial processes acting upon unconsolidated sediments, it is extremely unlikely that the channel would have been forced against one side of the valley so conspicuously. The channel is presently incised into the alluvium along reach $A-E$, and it appears that at the time the incision began the valley had been tilted enough to force the stream to flow along the west side of the valley. The depth of incision increases steadily upstream from 2 to $3 \mathrm{~m}$ at point $E$ to a spot about $100 \mathrm{~m}$ upstream from the confluence of Butano and Little Butano Creeks, where the depth of incision of Little Butano Creek reaches about $10 \mathrm{~m}$ at the base of a waterfall over bedrock. Above the waterfall the depth of incision does not exceed $3 \mathrm{~m}$. The depth of incision of Butano Creek also decreases above its confluence with Little Butano Creek.

Because the drainage area supplying sediment to the lower reaches of Butano Creek is asymmetrical, with greater area on the east side of the valley, it is possible that the stream channel could be forced against the west side of the valley by excess sediment contributed from the east side. I consider this unlikely because along some reaches there are no streams to contribute sediment from the east, but the stream nevertheless 


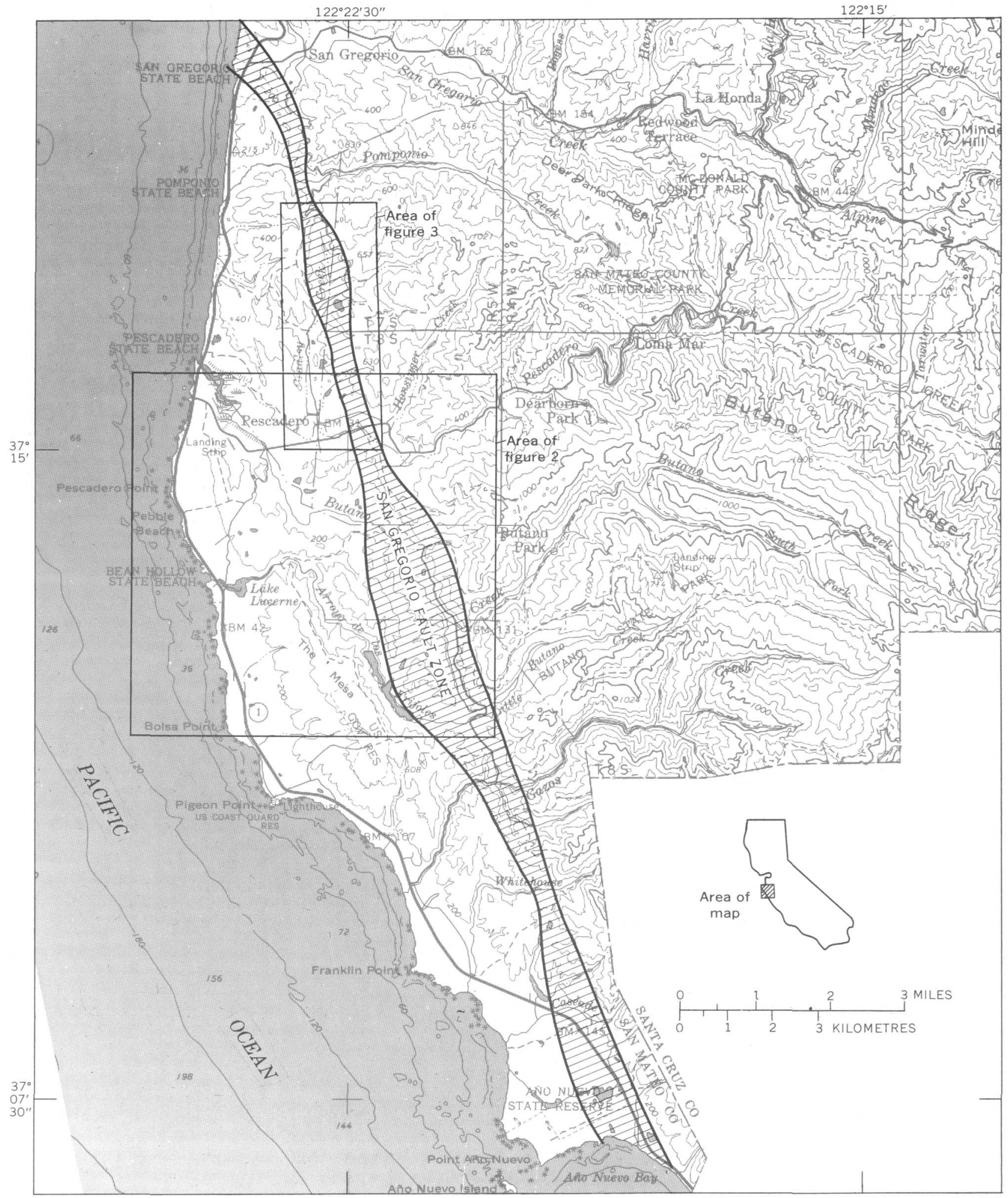

Figure 1.-Index map of southern San Mateo County, Calif., showing the San Gregorio fault zone as mapped by Brown (1972) and the areas of figures 2 and 3. Base from U.S. Geological Survey 1:125,000 San Francisco Bay region, sheet 3,1970 . 


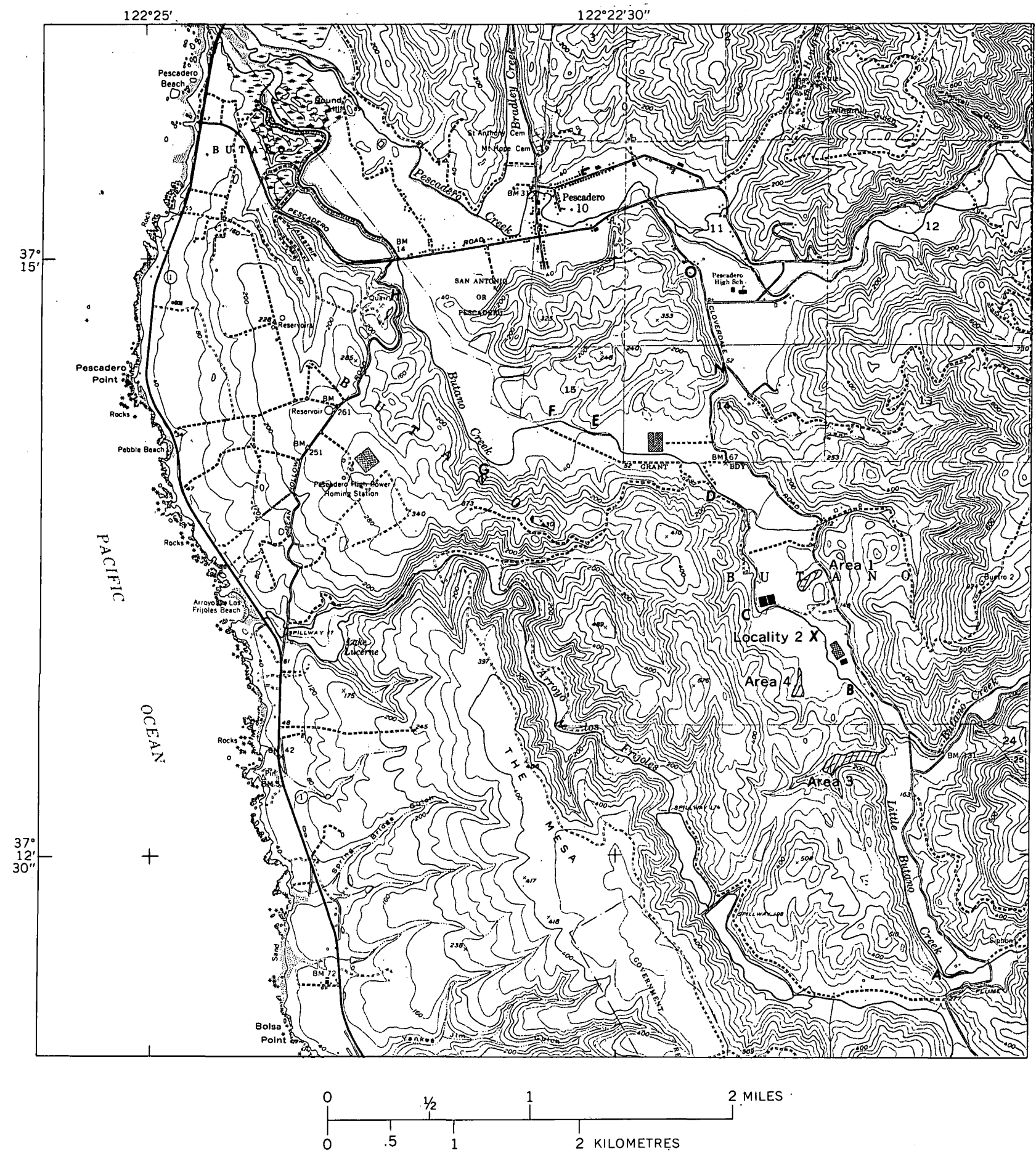

Figure 2.-Locations of swampy ground and stream channels along the lower alluviated reaches of Butano Creek and Little Butano Creek. Distribution of alluvium shown by areas of widely spaced contours along the valley bottoms in figures 2 and 3 ; letters indicate particular stream reaches discussed in this report. Base from U.S. Geological Survey 1:24,000 San Gregorio and La Honda, 1961; Pigeon Point and Franklin Point, 1955; all photo revised in 1968.

follows the west side of the valley. (for example, straight reach immediately downstream from point $A$ ).

Additional evidence for westward tilting appears at areas 3 and 4 (fig. 2), where dense thickets are found on the west side of the valley. At area 3 , the mouth of an eastward-draining tributary valley appears to have been elevated relative to the lower reaches of the stream, and this has caused ponding. In the wet month 
of December, 1972, there was standing water with an estimated maximum depth of about $50 \mathrm{~cm}$ at this area. The damming of the valley at area 3 could be the result of a natural levee built by Little Butano Creek at the mouth of the tributary. However, the same situation exists in area 4 where there is no stream to form a damming levee, therefore tilting seems to be the best explanation of the ponding.

Below point $E$ (fig. 2), Butano Creek is aggrading, probably because the creek is approaching sea level (the altitude at point $E$ is only about $13 \mathrm{~m}$ ). If the postulated tilting had been instantaneous, the stream channel would probably follow a meandering path across any alluvium deposited after the tilting. Instead, the stream follows the west edge of the valley along reach $G-H$, suggesting that some tilting may still be occurring.

The incision of the upper alluviated reaches of Butano Creek may be the result of a regional climatic change rather than an increase in stream gradient produced by tilting. However, if this were true, other local streams should be similarly incised, but the channel and valley bottom deposits of Bradley Creek are not.

\section{BRADLEY CREEK}

The alluviated valley of Bradley Creek (fig. 3) extends about $3 \mathrm{~km}$ north of the town of Pescadero. The valley is approximately parallel to the Butano Creek valley along reach $A-D$ (fig. 2), but Bradley Creek flows to the south.

Unlike the Butano Creek channel, the Bradley Creek channel is fairly shallow, with a maximum depth of incision of about $2 \mathrm{~m}$. This would be expected if the region were tilting to the northwest; the gradient of Butano Creek, which flows northwest, has steepened, whereas the gradient of Bradley Creek, which flows south, has decreased.

Two eastern tributaries of Bradley Creek follow paths that are consistent with the proposed tilting. The streams that issue from Tahana Gulch and Chandler Gulch both veer sharply to the north as they emerge onto their alluvial fans, as they should if northwestward tilting is occurring. However, the bends in the two channels line up with a similar bend in the stream in Shaw Gulch and may possibly be fault controlled. Somewhat less equivocal in nature is the stream channel in Chandler Gulch, which is confined along the north edge of the alluvial fill as the stream flows westward before it emerges from the hills onto the valley fill.

In the headward part of the drainage, along reach $K-L$ (fig. 3), the channel of Bradley Creek is located at the west edge of the valley fill. However, at this locality the position of the main stream may be controlled by a high sediment load coming from the east.

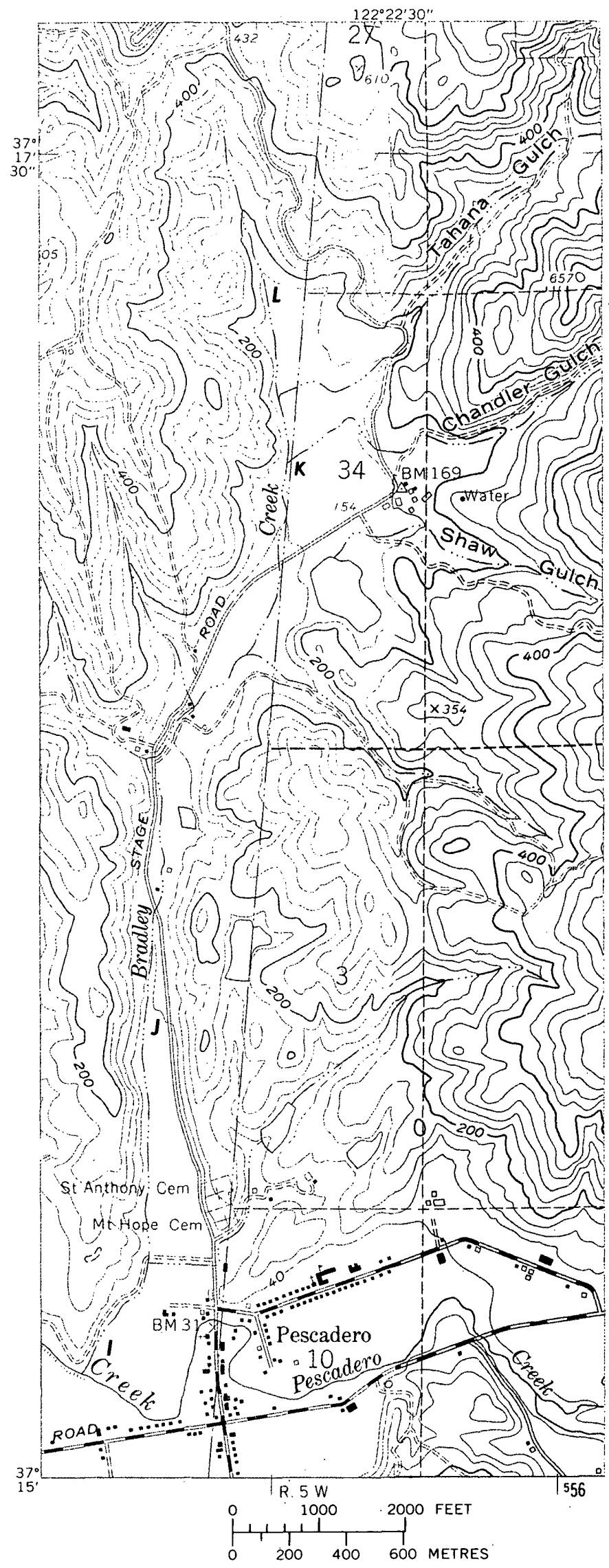

Figure 3.-Location of the channel of Bradley Creek. Base from U.S. Geological Survey 1:24,000 San Gregorio and La Honda, 1961, photorevised in 1968. 
A similar situation prevails south and west of Pescadero High School along Cloverdale Road, where the drainage follows a channel at the far west edge of the alluvium (fig. 2, reach $M-O$ ).

One should note that large local streams such as Pescadero Creek do not show the constrained stream channel patterns described above for Butano and Bradley Creeks. The path followed by a stream is the result of both hydraulic forces and external constraints such as tilting, and for the larger streams the effects produced by gentle tilting are relatively less important than for smaller streams. A large stream may thus show no record of tilting that has strongly affected lesser streams.

\section{AGE OF TILTING}

Two radiocarbon dates suggest that some of the observed tilting is geologically very young. The first date (I-6493) is from a perched bog that fills a small tributary valley in area 1 (fig. 2). A spring at the head of the valley has created wet conditions, and the valley is presently choked with swampy vegetation. A sediment core $10 \mathrm{~cm}$ in diameter and $215 \mathrm{~cm}$ long was removed from the upper end of the bog, and a sample of the mud from a depth of 137 to $147 \mathrm{~cm}$ yielded a radiocarbon age of $765 \pm 90 \mathrm{yr}$ B.P.

The second date (I-6678) is from scattered charcoal fragments collected by Andrei Sarna from the wall of the stream channel in fine-grained sediments at a depth of $1.5-3 \mathrm{~m}$ at locality 2 (fig. 2). This sample provided an age of $795 \pm 90 \mathrm{yr}$ B.P.

The two ages are remarkably consistent and very young. They indicate that the valley in the vicinity of the samples was still alluviating $750 \mathrm{yr}$ ago; alluviation may well have continued for some time after that. Alluviation must have occurred in response to normal fluvial processes, and the present unusual position of the stream channel must postdate the alluvium. If tilting is indeed the cause for the channel pattern, then the tilt within the past several hundred years has been of sufficient magnitude to affect the course and sediment transport mechanisms of both Butano and Bradley Creeks.

\section{DIRECTION OF TILTING}

The general direction of tilting may be approximated by the direction that the streams follow where they are not confined against the valley walls. Along Butano Creek, reaches $B-C$ and $D-E$ appear to be unconfined, and the streams emerging from Tahana and Chandler Gulches pursue similar directions where they bend to the north as they enter the heads of their alluvial fans. The direction of tilting measured from these stream courses is between N. $45^{\circ}$ W., and N. $65^{\circ}$ $W$. Whether the direction of tilting is uniform over the study area has not been determined.

\section{OTHER STREAMS}

Other streams in the vicinity of Pescadero, except for the small unnamed stream draining into Pescadero Creek from the valley just south of Pescadero High School, do not display the unusual stream channel patterns observed in Butano and Bradley Creeks. This is attributed to two causes: (1) Some streams, such as the Arroyo de los Frijoles, do not have much alluvium in their valleys, and (2) alluviated valleys such as Pescadero Creek and Scott Creek to the south (beyond the area shown in fig. 1) have larger drainage areas and stream flows and are thus able to override the controls that affect the channels of the smaller Butano and Bradley Creeks.

Alternative explanations exist for most of the data described in this paper. However, it has been demonstrated clearly that the study area has been tilting fairly steadily during the Pleistocene (LaJoie and others, 1972), and the purpose of the present paper is not to prove that the region has tilted but to show that tilting is still continuing. All the evidence presented here suggests modern tilting, and no evidence to refute such a hypothesis has been found.

\section{REFERENCES CITED}

Bradley, W. C., 1957, Origin of marine terrace deposits in the Santa Cruz area, California: Geol. Soc. America Bull., v. 68, p. $421-441$.

1958, Submarine abrasion and wave-cut platforms: Geol. Soc. America Bull., v. 69, p. 967-974.

- 1965, Marine terraces on Ben Lomond Mountain, California in Morrison, R. B., and Wahrhaftig, Clyde, eds., Guidebook for Field Conference 1 : Internat. Assoc. Quaternary Research 7th Cong. p. 148-150.

Bradley, W. C., and Addicott, W. O., 1968, Age of first marine terrace near Santa Cruz, California: Geol. Soc. America Bull., v. 79, p. 1203-1209.

Brown, Robert D., Jr., 1972, Active faults, probable active faults, and associated fracture zones, San Mateo County, California: U.S. Geol. Survey, Misc. Field Studies Map MF-355, scale 1:62,500.

Cooper, Allan, 1971, Structure of the continental shelf west of San Francisco, California: San Jose, Calif. State Univ. M.S. thesis, $65 \mathrm{p}$.

Jack, R., 1968, Quaternary sediments of the Montara Mountain area, San Mateo County : Berkeley, California Univ., M.A. thesis, 131 p.

Lajoie, K. R., Weber, G. E., and Tinsley, J. C., 1972, Marine terrace deformation-San Mateo and Santa Cruz Counties, in Progress report on the U.S. Geological Survey Quaternary studies in the San Francisco Bay area : Guidebook for Friends of the Pleistocene, October 6-8, 1972, p. 100-113.

Palmer, L. A., 1967 Marine terraces of California, Oregon, and Washington: Los Angeles, California Univ., Ph. D. thesis, 379 p.

Smith, D. D., 1960, Geomorphology of the San Francisco Peninsula : Stanford, Calif., Stanford Univ., Ph. D. thesis, $433 \mathrm{p}$.

Soil Conservation Service, 1961, Soil Survey San Mateo area, California : U.S. Dept. Agriculture, Soil Conserv. Service, Ser. 1954, no. 13, 35 p. 


\title{
FOSSIL FISHES FROM THE PLIOCENE OR PLEISTOCENE CACHE FORMATION, LAKE COUNTY, CALIFORNIA
}

\author{
By RICHARD W. CASTEEL and MICHAEL J. RYMER, \\ Menlo Park, Calif.
}

\begin{abstract}
The remains of fossil fishes comprising three species were found in the Cache Formation in Lake County, Calif. The rocks containing the fossils are considered to be late Pliocene or early Pleistocene. The species are all freshwater and primarily quiet-water types that now live in Clear Lake and the waters of the surrounding area, suggesting continuity between the present lake and a lake represented by the rocks of the Cache Formation.
\end{abstract}

In one of the earliest works on the geology of the Clear Lake area, Becker (1888) named and described the Cache Lake beds, from which he collected numerous pelecypods and gastropods. He noted that the mollusks were types presently known to live in or near Clear Lake. Becker also recovered a few fragmentary terrestrial mammal remains, which were forwarded to Dr. O. C. Marsh and tentatively identified as those of a horse, a camel, and an elephant or mastodon, suggesting a very late Pliocene age for the deposits.

Becker's Cache Lake beds was renamed the Cache Formation by Anderson (1936, p. 633) because, although part of the formation was undoubtedly lacustrine, it also contained a fluvial facies. From imprints of rushes found in the Cache west of the North Fork of Cache Creek, Anderson inferred that the Cache Formation was deposited in a subsiding basin. The deposits along the east side of the southern arm of present Clear Lake were described as lacustrine diatomite and limestone. Numerous freshwater mollusks and diatoms were reported. Anderson (1936, p. 638) believed that the topography during deposition of the Cache Formation was markedly different from that of the present. Study of the diatoms by G. D. Hanna indicated no connection between the lakes of Cache time and the present Clear Lake. Anderson also reported the identification by V. L. VanderHoof of Elephas sp. of Pleistocene age.

A later collection of fossil vertebrates of late Pliocene or early Pleistocene age from Anderson's Cache Formation, made at the University of California $\mathrm{Mu}$ seum of Paleontology locality V-6421 (lat $39^{\circ} 59^{\prime} 45^{\prime \prime}$
N., long $122^{\circ} 31^{\prime} 45^{\prime \prime}$ W.), included Equus, Canidae, Procyon, Titanotylopus, Nothrotherium, Cervidae, and Geochelone (J. H. Hutchison, oral commun., December 1974).

The age of the Cache Formation has been established as late Pliocene or early Pleistocene. See Anderson (1936) for a brief summary of reported fossil evidence bearing on the age of the Cache.

There are two interpretations of the history of Clear Lake and its relation to the Cache Formation. The first maintains that the present Clear Lake occupies the structural depression in which the Cache Formation was deposited (Becker, 1888; Brice, 1953; Hodges, 1966) and that the histories of the two depressions are continuous. The second argues that present Clear Lake occupies a flooded intermontane basin with its outlets dammed. Previous drainage of the basin was supposedly divided with the western part tributary to the Russian River and the eastern part tributary to the Sacramento River (Davis, 1931, 1933; Hinds, 1952; Goldman and Wetzel, 1963; Stetson, 1957; Lallatin and Wood, 1966). Proponents of the second interpretation see a discontinuous relation between the Cache Formation and Clear Lake. (See also Anderson, 1936.)

\section{DESCRIPTION OF FOSSIL FISHES}

The remains of fossil fishes were found by M. J. Rymer in a roadcut $0.3 \mathrm{~km}(1,000 \mathrm{ft})$ north of the intersection of State Highway 53 and the Lower Lake Road (fig. 1). They were recovered from a bed of diatomaceous, tuffaceous claystone that dips $65^{\circ} \mathrm{N}$. Associated with the fish remains are freshwater gastropods, pelecypods, ostracods, and diatoms. This is the first reported occurrence of fossil fishes from the Cache Formation. The fish remains belong to three species, as described below.

\section{Family CYPRINIDAE}

Orthodon cf. O. microlepidotus (Ayres) (Sacramento blackfish)

Referred material (USNM 1840'\%). - The only recovered material of this species is a pharyngeal tooth, broken at its base below the enamel (fig. $2 A$ ). The 


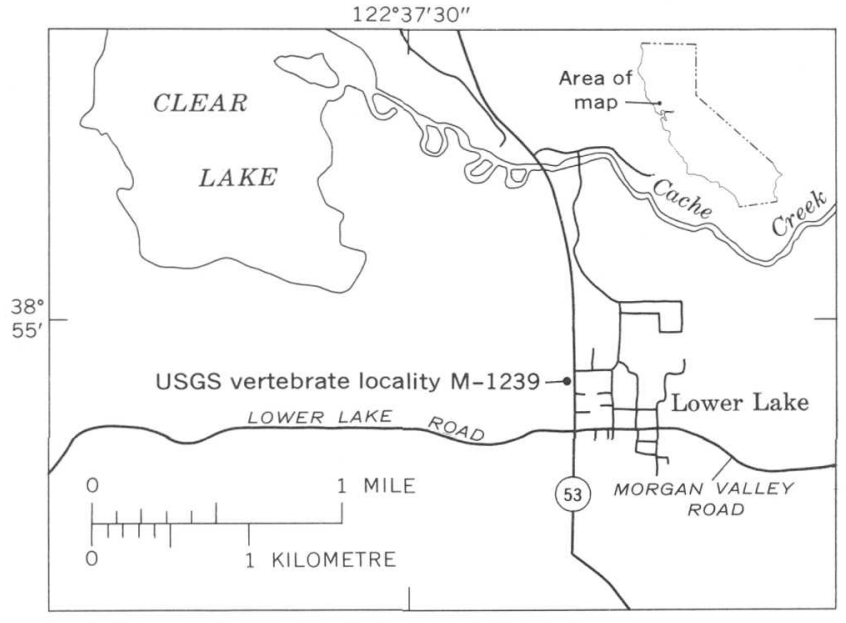

Figure 1.-Map showing location of vertebrate fossils (USGS vertebrate loc. M-1239) near town of Lower Lake, Calif.

pharyngeal teeth of Orthodon microlepidotus are highly distinctive. They are compressed, lancet shaped, and nearly straight, and possess a long, narrow, and well-developed grinding surface on the dorsal side. Other fossil remains of this species, referred to as
Orthodon sp., have been reported from central California and range in age from Pliocene (Hemphillian) to late Pleistocene (Rancholabrean) (Casteel and Hutchison, 1973). This species is a highly specialized, microphagus cyprinid (Hopkirk, 1974, p. 63) endemic to the modern California freshwater fish fauna. It is presently a native constituent of the ichthyofaunas of the Clear Lake, Russian River, and Sacramento River systems (Hopkirk, 1974). Jordan and Gilbert (1894, p. 139) stated that O. microlepidotus was the most common fish in Clear Lake before the turn of the century, and Cook, Moore, and Conners (1966, p. 151) reported that it still occurs in large numbers in the lake. It, like the other species described below, is most commonly found in the Hitch zone (Hopkirk, 1974). This zone is defined as a distinctive assemblage of resident native freshwater fishes presently occupying the fast- to slow-moving and standing waters in the Lower Sonoran and, occasionally, the Upper Sonoran life zones of central California. This zone is characterized by the occurrence of O. microlepidotus (Ayers) (Sacramento blackfish), Pogonichthys macrolepidotus (Ayres) (splittail), Gila crassicauda (Baird and
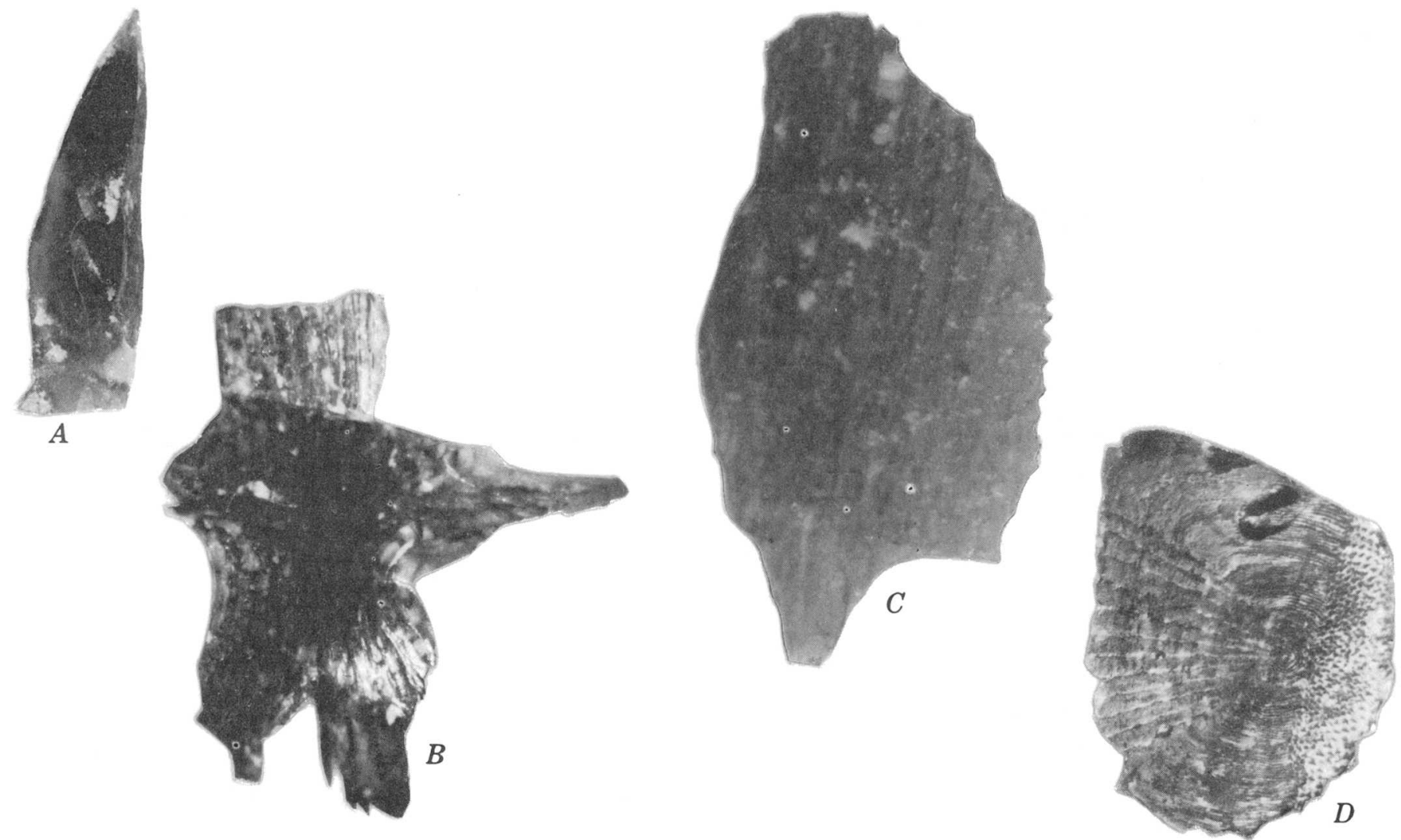

FIgure 2.-Fossil fish remains from the Cache Formation (USGS vertebrate loc. M-1239). All illustrations $\times 10$. A, Pharyngeal tooth of Orthodon cf. O. microlepidotus (Ayres) (USNM 184072). B, Fragment of central part of right-lateral scute of Gasterosteus cf. G. aculeatus Linnaeus (USNM 184073). C, Fragment of scute of Gasterosteus cf. G. aculeatus Linnaeus USNM 184074). D, Ctenoid scale of Archoplites cf. A. interruptus (Girard) (USNM 184075). Anterior field of scale is to left. 
Girard) (thicktail chub), Hysterocarpus traski Gibbons (Tule perch), Archoplites interruptus (Girard) (Sacramento perch), Cottus asper Richardson (prickly sculpin), and Gasterosteus aculeatus Linnaeus (threespine stickleback).

\section{Family GASTEROSTEIDAE}

Gasterosteus cf. G. aculeatus Linnaeus (three-spine stickelback)

Referred material (USNM 184073 and USNM 1840\%4).-The remains include a fragment of the central part of a right-lateral scute with its posterior projection and another scute fragment (figs. $2 B, C$ ). These elements show the same pattern of radiating ridges with projecting spines along the outer surface of the striae as is found in recent examples of Gasterosteus aculeatus. Fossil occurences of the genus Gasteroteus have been noted for Nevada (Jordan, 1908; Mural, 1973) and are dated as early Pliocene (Hay, 1907; Uyeno and Miller, 1963).

$G$. aculeatus is primarily a member of the fish fauna of the Hitch zone. It appears to have been a member of the present native ichthyofauna of the Clear Lake, Russian River, and Sacramento River systems (Cook and others, 1966; Jordan and Gilbert, 1894; Murphy, 1951), but there is some doubt as to its continued presence in Clear Lake (Cook and others, 1964, 1966).

\section{Family CENTRARCHIDAE}

\section{Archoplites cf. A. interruptus (Girard) (Sacramento perch)}

Referred material (USNM 1840\%5).--One ctenoid scale from Archoplites interruptus (fig. $2 D$ ) was recovered from the fossil locality. See Casteel (1972) for characteristics of the scale of this species. Remains of the genus Archoplites have been reported from the central valley of California (Hansen and Begg, 1970), dated at 103,000 $\pm 6,000$ years; from the Pliocene and Pleistocene Glenns Ferry Formation, Idaho (Miller, 1965; Miller and Smith, 1967); and from the early or middle Pleistocene at Moses Lake, Wash. (Miller 1965). A scale of this species was identified by Jordan (1927, p. 96) from a probable Pleistocene deposit at Tulare Lake, Calif.

Archoplites is presently a monotypic genus endemic to the California freshwater fish fauna (Miller, 1959; Hopkirk, 1974). It is native to the Clear Lake, Russian River, and Sacramento River systems (Hopkirk, 1974; Cook and others, 1966; Murphy, 1951; Jordan and Gilbert, 1894). Like the other fishes discussed above, A. interruptus is primarily a member of the Hitch zone.

\section{DISCUSSION}

Mammal remains indicate a late Pliocene or early Pleistocene age for Anderson's (1936) Cache Forma- tion. The fish remains are referrable to species presently living in and around Clear Lake, in the immediate vicinity of the Cache Formation. The fish species described here are primarily resident members of the Hitch zone, an assemblage of freshwater fishes characteristic of deep channel areas with sluggish currents (Hopkirk, 1974).

The fact that these fish species are still present in Clear Lake, combined with their preference for lacustrine or slow-current fluvial environments, argues in favor of Becker's (1888) view regarding continuity between the lacustrine environment of the Cache Formation and Clear Lake. At the very least these remains indicate similar depositional environments in the present Clear Lake and the Cache Formation at this locality.

\section{REFERENCES CITED}

Anderson, C. A., 1936, Volcanic history of the Clear Lake area, California: Geol. Soc. America Bull., v. 47, p. 629-664.

Becker, G. F., 1888, Geology of the quicksilver deposits of the Pacific slope, with an atlas: U.S. Geol. Survey Mon. 13, $486 \mathrm{p}$.

Brice, J. C., 1953, Geology of the Lower Lake quadrangle, California: California Div. Mines Bull. 166, 72 p.

Casteel, R. W., 1972, A key, based on scales, to the families of native California freshwater fishes: California Acad. Sci. Proc., v. 39, no. 7, p. 75-86.

Casteel, R. W., and Hutchison, J. H., 1973, Orthodon (Actinopterygii, Cyprinidae) from the Pliocene and Pleistocene of California: Copeia, no. 2, p. 358-361.

Cook, S. F., Jr., Conners, J. D., and Moore, R. L., 1964, The impact of the fishery upon the midge populations of Clear Lake, Lake County, California: Entomol. Soc. America Ann., v. 57, no. 6, p. 701-707.

Cook, S. F., Jr., Moore, R. L., and Conners, J. D., 1966, The status of the native fishes of Clear Lake, Lake County, California : Wasmann Jour. Biology, v. 24, no. 1, p. 141-160.

Davis, W. M., 1931, Clear Lake, California: Science, v. 74, p. 572-573.

- 1933, The lakes of California: California Div. Mines and Geology State Mineralogist's Rept., v. 29, no. 1 and 2, p. $175-236$.

Goldman, C. R., and Wetzel, R. G., 1963, A study of the primary productivity of Clear Lake, Lake County, California : Ecology, v. 44, no. 2, p. 283-294.

Hansen, R. O., and Begg, E. L., 1970, Age of Quaternary sediments and soils in the Sacramento area, California, by uranium and actinium series dating of vertebrate fossils: Earth and Planetary Sci. Letters, v. 8, no. 6, p. 411-419.

Hay, O. P., 1907, A new fossil stickleback fish from Nevada: U.S. Natl. Mus. Proc., v. 32, no. 1528, p. 271-273.

Hinds, N. E. A., 1952, Evolution of the California landscape: California Nat. Resources Div. Mines Bull. 158, 240 p.

Hodges, C. A., 1966, Geomorphic history of Clear Lake, California : Stanford Univ., Ph. D. thesis, $171 \mathrm{p}$.

Hopkirk, J. D., 1974, Endemism in fishes of the Clear Lake region of central California : California Univ. Pubs. Zoology $96,135 \mathrm{p}$

Jordan, D. S., 1908, Note on a fossil stickleback fish from Nevada: Smithsonian Misc. Colln., v. 52, p. 117. 
1927, the fossil fishes of the Miocene of southern California : Stanford Univ. Pubs. Biol. Sci., v. 5, no. 2, p. 85-99. Jordan, D. S., and Gilbert, C. H., 1894, List of the fishes inhabiting Clear Lake, California: U.S. Bur. Fisheries Bull. 14, p. 139-140.

Lallatin, R. D., and Wood, W. W., 1966, Clear Lake water quality investigation: California Dept. Water Resources Bull. 143-2, 202 p.

Miller, R. R., 1959, Origin and affinities of the freshwater fish fauna of western North America, in Hubbs, C. L., ed., Zoogeography: Am. Assoc. Adv. Sci. Pub. 51, p. 187-222.

1965. Quaternary freshwater fishes of North America, in Wright, H. E., Jr., and Frey, D. G., eds., The Quaternary of the United States: Princeton, Princeton Univ. Press, p. 569-581.
Miller, R. R., and Smith, G. R., 1967, New fossil fishes from Plio-Pleistocene Lake Idaho: Michigan Univ. Mus. Zoology Occasional Paper 654, 24 p.

Mural, R. J., 1973, The Pliocene sticklebacks of Nevada with a partial osteology of the Gasterosteidae: Copeia, no. 4, p. 721-735.

Murphy, G. I., 1951, The Fishery of Clear Lake, Lake County, California : California Fish and Game, v. 37, no. 4, p. 439484.

Stetson, T. M., 1957, Lake County investigation: California Dept. Water Resources Bull. 14, 206 p.

Uyeno, Teruya, and Miller, R. R., 1963, Summary of late Cenozoic freshwater fish records for North America : Michigan Univ. Mus. Zoology Occasional Paper 631, 34 p. 


\title{
REVISED VALUE FOR THE $0^{18}$ FRACTIONATION BETWEEN $\mathrm{CO}_{2}$ AND $\mathrm{H}_{2} \mathrm{O}$ AT $25^{\circ} \mathrm{C}$
}

\author{
By JAMES R. O'NEIL, LANFORD H. ADAMI; and SAMUEL EPSTEIN, \\ Menlo Park, Calif.; Pasadena, Calif.
}

\begin{abstract}
A new value of 1.0412 for the fractionation factor $a$ between $\mathrm{CO}_{3}$ and $\mathrm{H}_{2} \mathrm{O}$ at $25^{\circ} \mathrm{C}$ is recommended on the basis of new data and a reevaluation of earlier published data.
\end{abstract}

Inasmuch as the $\mathrm{O}^{18} / \mathrm{O}^{16}$ ratio of water is usually determined by the precise $\mathrm{CO}_{2}$-equilibration technique, it is essential to know the fractionation factor between $\mathrm{CO}_{2}$ and $\mathrm{H}_{2} \mathrm{O}$ to relate the isotopic compositions of water to other oxygen-containing substances. Several values of this important fractionation factor, ranging from 1.0407 to 1.0424 , have appeared in the literature in the last decade (Compston and Epstein, 1958; Staschewski, 1964; Majzoub, 1966; O'Neil and Epstein, 1966; Bottinga and Craig, 1969; Matsuhisa and others, 1971; Blattner, 1973). This spread of 1.7 per mil poses a serious problem in a discipline in which differences of $<0.20$ permil in $\mathrm{O}^{18} / \mathrm{O}^{16}$ ratio may be significant. Measurements made in 1968 at the U.S. Geological Survey in Menlo Park and reevaluation of earlier Caltech data result in a new value of the fractionation factor which we believe to be more nearly correct and which resolves other problems to be discussed below.

O'Neil and Epstein (1966) reported a technique for analyzing milligram quantities of water directly by reaction with $\mathrm{BrF}_{5}$ and reported a $\mathrm{CO}_{2}-\mathrm{H}_{2} \mathrm{O}$ fractionation factor $(\alpha)^{1}$ of $1.0407 \pm 0.0004$ which was in agreement with an earlier value obtained by Compston and Epstein (1958) in same laboratory. We suggested that differences between this value and others reported might be due to mass-spectrometer differences because the factor was so large. Indeed, although the average error of our $\alpha$ was only \pm 0.0002 , we judged that \pm 0.0004 was a more realistic analytical error because of the inherent limitations of the mass spectrometer. At the time of our experiments, the behavior of the Caltech instrument was somewhat erratic and the instrument correction factor appeared to be too large. Because of the importance of the $\mathrm{CO}_{2}-\mathrm{H}_{2} \mathrm{O}$ fractionation factor, a comparison check was made with the La Jolla instrument in the laboratory of Prof. Harmon Craig who kindly analyzed a few $\mathrm{CO}_{2}$ samples that

$$
{ }_{1} a=\frac{\left(\mathrm{O}^{18} / \mathrm{O}^{16}\right) \mathrm{CO}_{2}}{\left(0^{18} / \mathrm{O}^{10}\right) \mathrm{H}_{2} \mathrm{O}} \text {. }
$$

were previously analyzed at Caltech. An instrument correction factor of 1.0136 based on this comparison was significantly different from the normal Caltech value of 1.0263 but was nonetheless used in calculating the fractionation factors reported in our previous article (O'Neil and Epstein, 1966). If the normal correction is applied to our earlier data, the fractionation factor changes from 1.0407 to 1.0412 :

$$
40.7 \times \frac{1.0263}{1.0136}=41.2 .
$$

The decision to reevaluate these data is based upon new data obtained in the U.S. Geological Survey laboratory in Menlo Park on the four IAEA (International Atomic Energy Agency) water standards distributed for interlaboratory comparison. The Geological Survey had agreed to analyze these waters by both the $\mathrm{CO}_{2}$-equilibration technique and $\mathrm{BrF}_{5}$ technique as a demonstration of their relative precision, and, of course, a $\mathrm{CO}_{2}-\mathrm{H}_{2} \mathrm{O}$ fractionation factor can be calculated from these data. The results are listed in table 1 . The average fractionation factor is given to the nearest 0.1 permil, although the precision of the analyses is somewhat better than this.

TABLE 1.- $\mathrm{O}^{18}$ fractionation factors between $\mathrm{CO}_{2}$ and the IAEA water standards at $25^{\circ} \mathrm{C}$

[SMOW, standard mean ocean water; NBS, National Bureau of Standards]

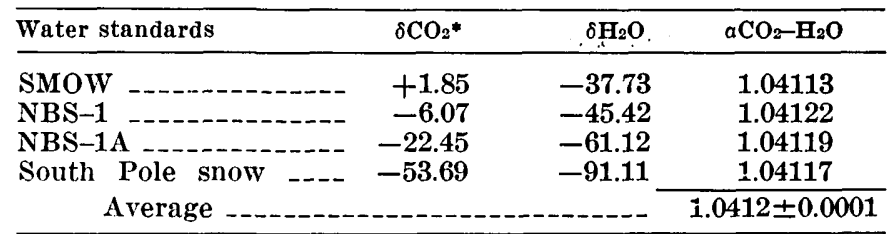

- $\delta$ values are given relative to the working standard in the U.S. Geological Survey laboratory in Menlo Park.

During the time of these experiments, the Menlo Park instrument was in good working order and the mass-spectrometer correction factor of 1.0150 was constant. We do not believe the agreement between the new data and the revised data to be coincidental and, in fact, the new factor is identical to the one determined by Matsuhisa, Matsubaya, and Sakai (1971). This fractionation factor of 1.0412 resolves the prob- 
lem of the two different definitions of SMOW (standard mean ocean water) that appear in the literature.

SMOW was defined by Craig (1961) in the following way:

$$
\left(\mathrm{O}^{18} / \mathrm{O}^{16}\right)_{\text {smow }}=1.008\left(\mathrm{O}^{18} / \mathrm{O}^{16}\right)_{\mathrm{NBS}-1}
$$

where NBS-1 is Potomac River water distributed by the National Bureau of Standards as a stable-isotope standard. Another ocean water standard called SMOW (used chiefly by the Caltech stable-isotope laboratory) is a water of such isotopic composition that relative to it, a sample of Potsdam sandstone is +15.5 . The relation between these two ocean waters has been discussed twice (Clayton and Mayeda, 1963; O'Neil and Epstein, 1966) and in both papers they were said to be close enough to each other in isotopic composition that no serious complications would ensue as a result of their use. We still believe this to be true but realize that in the other examples mentioned it was a matter of remarkable fortuity because, again, incorrect massspectrometer correction factors were being used in the laboratories of those discussing the problem.

Deveraux (1968) has pointed out that in the laboratories of the University of Chicago and the Department of Scientific and Industrial Research, New Zealand, Potsdam sandstone is +15.0 relative to SMOW as defined by Craig. This we now believe to be a result of the use of the factor 1.04 .07 in these laboratories to relate their working standards to SMOW in terms of NBS-1, as analyzed by the $\mathrm{CO}_{2}$-equilibration technique.

Bottinga and Craig (1969) have reported a $\mathrm{CO}_{2-}$ $\mathrm{H}_{2} \mathrm{O}$ fractionation factor at $25^{\circ} \mathrm{C}$ of $1.0409 \pm 0.0002$ based on a procedure similar to that described in an earlier paper (O'Neil and Epstein, 1966) and used by Matsuhisa, Matsubaya, and Sakai (1971). They correctly point out that the agreement between their value and ours may be a result of our interlaboratory calibration of mass spectrometers. We realize now that the instrument factor of 1.0136 was not generally applicable to our results over the duration of the experiments and indeed has not been used in any other work in the Caltech laboratory. We now look to an explanation for the small difference between our revised value of 1.0412 and the Bottinga-Craig value of 1.0409 . Again the difference may be, in part, inherent in the mass spectrometry. A difference this small could be due to something as simple as the way in which the background correction is measured. In addition, it may be important that Bottinga and Craig did not measure yields on their $\mathrm{BrF}_{5}-\mathrm{H}_{2} \mathrm{O}$ reactions. We know this to be essential and did not issue a strong enough warning on this matter in our 1966 paper. As in all fluorination procedures for oxygen isotope work, there are occasional variations in the oxygen yield and when the yields are more than approximately 1 percent different from 100, an incorrect analysis may result. In the analyses of the IAEA waters reported here, a few of our runs gave low yields ( $\approx 96-98$ percent) with fairly reproducible isotope ratios which were from 0.3 to 0.6 permil heavier than the ratios in those runs with 100 percent yields. Unless the yield was within $\approx 0.5$ percent of 100 , the results were discarded. Such problems again point to the fact that the $\mathrm{CO}_{2}$-equilibration technique will always be the method of choice when enough water is available.

Comparisons of the various determinations of this fractionation factor must be viewed in light of the analytical procedures employed and, very importantly, the inherent limitation of mass spectrometers. We are aware that unpublished determinations have been made in other laboratories and that the results continue to cluster around 1.041. Complications will ensue if all workers in the field of stable isotope geochemistry do not use the same value of this important factor. It may be necessary to define a value. However, the fact that the value of 1.0412 has now been independently determined in three laboratories is in our opinion sufficient justification for recommending its adoption.

\section{REFERENCES CITED}

Blattner, Peter, 1973, Oxygen from liquids for isotopic anal-

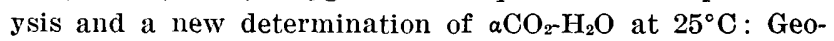
chim. et Cosmochim. Acta, v. 37, p. 2691-2693.

Bottinga, Y., and Craig, H., 1969, Oxygen isotope fractionation between $\mathrm{CO}_{2}$ and water, and the isotopic composition of marine atmospheric $\mathrm{CO}_{2}$ : Earth and Planetary Sci. Letters, v. 5, no. 5, p. 285-295.

Clayton, R. N., and Mayeda, T. K., 1963, The use of bromine pentafluoride in the extraction of oxygen from oxides and silicates for isotopic analysis: Geochim. et Cosmochimica Acta, v. 27, no. 1, p. 43-52.

Compston, W., and Epstein, Samuel, 1958, A method for the preparation of carbon dioxide from water vapor for oxygen isotope analysis [abs.]: Am. Geophys. Union Trans., v. 39, p. 511-512.

Craig, Harmon, 1961, Standard for reporting concentrations of deuterium and oxygen-18 in natural waters: Science, v. 133 , no. 3467 , p. $1833-1834$.

Deveraux, I., 1968, Oxygen isotope ratios of minerals from the regionally metamorphosed schists of Otago. New Zealand: New Zealand Jour. Sci., v. 11, p. 526-547.

Majzoub, M. A., 1966, Une méthode d'analyse isotopique de l'oxygène sur les microquantités d'ean; détermination des coefficients de partage a l'équilibre de l'oxygène 18 entre $\mathrm{H}_{2} \mathrm{O}$ et $\mathrm{CO}_{2} ; \mathrm{D}_{2} \mathrm{O}$ et $\mathrm{CO}_{2}:$ Jour. Chim. Physics, v. 63, no. 4, p. 563-568.

Matsuhisa, Y. Matsubaya, O., and Sakai, H., 1971, BrF-technique for the oxygen isotopic analysis of silicates and water: Mass Spectroscopy, v. 19, 124-133.

O'Neil, J. R., and Epstein, Samuel, 1966, A method for oxygen isotope analysis of milligram quantities of water and some of its applications: .Jour. Geophys. Research, v. 71, no. 20, p. $4955-4961$.

Staschewski, D. 1964, Experimentelle Bestimmung der $\mathrm{O}^{18} / \mathrm{O}^{16}$ Trennfaktoren in den Systemen $\mathrm{CO}_{2} / \mathrm{H}_{2} \mathrm{O}$ und $\mathrm{CO}_{2} / \mathrm{D}_{2} \mathrm{O}$ : Bunsengesell. Phys. Chem. Ber., v. 68, p. 454-459. 


\title{
SPECTROCHEMICAL DETERMINATION OF TRACE ELEMENTS IN GALENA
}

\author{
By E. L. MOSIER, J. C. ANTWEILER, and J. M. NISHI, \\ Denver, Colo.
}

\begin{abstract}
A semiquantitative spectrochemical method is described by means of which $10-\mathrm{mg}$ samples of galena can be analyzed for their trace element content. Results on 40 elements are reported as six logarithmically spaced intervals per order of magnitude and obtained by visual comparison with standards prepared in spectrographically pure lead sulfide. Detection limits are generally between 1 and $20 \mathrm{ppm}$ (except for $\mathrm{Ce}, \mathrm{Na}, \mathrm{Sr}, \mathrm{Ta}$, and $\mathrm{Zn}$, which are 50 to $100 \mathrm{ppm}$ ). Replicate analyses of galena samples indicate a precision comparable to other semiquantitative spectrochemical methods used for the analysis of geochemical samples. Results obtained from the analysis of 129 galena samples are summarized.
\end{abstract}

Minor elements in sulfide minerals have been widely studied to gain information relative to ore genesis. Much of the early work on minor elements in sulfide minerals, including galena, was summarized by Fleischer (1955). Since 1955, investigators who have studied the trace element content of galena to shed light on the problem of ore genesis include Chakrabarti (1967), Graeser (1969), Bethke and Barton (1971), Hall, Rose, and Simon (1971), Hall and Heyl (1968), Rivas and Pinto (1967), and Malakhov (1968). In addition, Marshall and Joensuu (1961) investigated the trace element content of galena as related to crystal habit.

The main purpose of this paper is to describe a semiquantitative spectrographic method for the analysis of trace elements in galena, and to demonstrate its practicality by summarizing the results of the analysis of 129 sulfide concentrates composed mainly of galena. The samples were accumulated over a period of several years; most were collected for other purposes such as isotopic lead analyses (some of which were previously reported in Delevaux, Pierce, and Antweiler, 1966) or as byproducts of samples concentrated to recover gold. They came from several localities in Colorado, including the Central City, Leadville, Silverton, Aspen, and Eagle districts, and districts in Lake, Boulder, and Routt Counties. Galenas were also analyzed from the States of Nevada, New Mexico, Wyoming, Idaho, Montana, and Washington, as well as from Greenland and Africa.

\section{EQUIPMENT}

Spectrograph : 1.5-metre Wadsworth-mounted, having a dispersion of $5.45 \AA$ (angstroms) per millimetre over the spectral range from 2,100 to $4,800 \AA$ in the second order.

Source: Direct-current arc; $220-V$ input and maximum arc current of 15 amp (amperes).

Slit width : 10 microns.

Sample electrode: Ultra Carbon 101L anode.

Counter electrode: Ultra Carbon 5001.

Filter: Neutral two-step quartz, 100 percent over 41percent transmission, with a $1-\mathrm{cm}$ mask on grating.

Comparator: Jarrell-Ash console microphotometer (Model 21-000).

Film: 35-mm Kodak Spectrum Analysis No. 1, processed with D-19 developer for 3 min at $20^{\circ} \mathrm{C}$.

\section{STANDARDS}

Standards are prepared by mixing appropriate quantities of spectrographically pure compounds of each element, usually the oxide or carbonate, into spectrographically pure lead sulfide. To obtain a series of standards in successively lower amounts to cover the desired concentration ranges, a dilution factor equal to the reciprocal of the cube root of $10(0.464)$ is used. By use of the 0.464 dilution factor, the successive standards prepared contain concentrations in order of magnitudes of $100,46.4,21.5,10$, and so forth. When comparisons are made with sample films for semiquantitative use, these numbers are rounded to 100 , $50,20,10$, and so forth. Those lines which are estimated to fall between the above values are arbitrarily given values of 70,30,15, and so forth (Ward and others, 1963 , p. 92). This method of preparing standards has been commonly referred to as the six-step method by U.S. Geological Survey laboratories, and is described more fully by Bastron, Barnett, and Murata (1960), Myers, Havens, and Dunton (1961), and Grimes and Marranzino (1968). The standards are shown in table 1.

Fleischer (1955) stated that minor elements occur in minerals as trace elements in the crystal lattice or as 
TABLE 1.-Rounded concentrations, in parts per million, of elements in standards

\begin{tabular}{|c|c|c|c|c|}
\hline $\begin{array}{c}\text { Standard } \\
\text { No. }\end{array}$ & $\begin{array}{c}\mathrm{Ag}, \mathrm{As}, \mathrm{Cu} \\
\mathrm{Fe}, \mathrm{Sb}, \mathrm{Zn}\end{array}$ & $\begin{array}{l}\mathrm{Bi}, \mathrm{Ce}, \mathrm{Si} \text {, } \\
\text { Te, w, Zr }\end{array}$ & $\begin{array}{c}\mathrm{Al}, \mathrm{Au} \\
\mathrm{Ca}, \mathrm{Mg}, \\
\mathrm{Mn}\end{array}$ & $\begin{array}{l}\text { B. Ba, Be, Cd, } \\
\text { Co, Cr, Ga, Ge, } \\
\text { Hg, In, La, Mo, } \\
\text { Na, Nb, Ni; Sc, } \\
\text { Sn, Sr, Ta, Ti, } \\
\text { Tl, V, Y }\end{array}$ \\
\hline 1 & 50,000 & & ---- & \\
\hline 2 & 20,000 & 20,000 & & - - \\
\hline 3 & 10,000 & 10,000 & 10,000 & -------- \\
\hline 4 & 5,000 & 5.000 & 5,000 & - \\
\hline$\overline{5}$ & 2,000 & 2,000 & 2,000 & 2,000 \\
\hline 6 & 1,000 & 1,000 & 1,000 & 1,000 \\
\hline 7 & 500 & 500 & 500 & 500 \\
\hline 8 & 200 & 200 & 200 & 200 \\
\hline 9 & 100 & 100 & 100 & 100 \\
\hline 10 & 50 & 50 & 50 & 50 \\
\hline 11 & 20 & 20 & 20 & 20 \\
\hline 12 & 10 & 10 & 10 & 10 \\
\hline 13 & 5 & 5 & 5 & 5 \\
\hline 14 & 2 & 2 & 2 & 2 \\
\hline 15 & 1 & $\overline{1}$ & $\overrightarrow{1}$ & 1 \\
\hline 16 & 0.5 & 0.5 & 0.5 & 0.5 \\
\hline
\end{tabular}

trace elements in various types of mineral inclusions. Some of the galena samples used in this study contained appreciable amounts of several minerals including some sulfides. The trace elements, therefore, may be present in the samples in a different form from the oxides and carbonates which were used to make the standards. To determine whether the volatilization rates of the elements being analyzed in the samples were similar to the volatilization rates of the elements in the standards, a moving-plate study was made of both sample and standards. The volatilization versus time curves are shown in figure 1 for a few selected elements. The curves shown here are representative of all elements sought.

The curves show that the volatilization rates of the elements in the standards are similar to the volatilization rates of the elements in the samples even though there is a physical as well as chemical difference between sample and standard in the manner in which the elements are present. The moving-plate study also showed that volatile elements when present at very low concentrations were quantitatively volatilized in the first $30 \mathrm{~s}$ of the burn.

\section{ANALYTICAL PROCEDURE}

\section{Sample preparation}

The samples.were prepared by elaborate purification procedures, or by handpicking, or by crushing galena crystals, or by. concentrating in a gold pan. Care was exercised tơ obtain as pure a galena sample as possible, but many of the samples contained traces of other minerals. Individual crystals ranged in size from a fraction of a millimetre to approximately $10 \mathrm{~mm}$. Prior to analysis, all samples were handground in an agate mortar to minus 150 mesh.

\section{Analysis}

Sample electrode charge: Weigh $10 \mathrm{mg}$ of the prepared sample and $10 \mathrm{mg}$ of buffer (pelletizing graphite containing 5 percent lithium carbonate) into the same weighing pan and manually mix. (The small amount of lithium carbonate added to the graphite gives a smoother burn with less background than when graphite only is used.) Transfer the mixture into the cavity of a preformed electrode (Ultra Carbon 101L or equivalent) with the aid of a Teflon funnel, and pack tightly with a venting tool.

Use a $5-\mathrm{mm}$ analytical gap in the following arc sequence: (1) Position the two-step filter (100- and 41percent transmission) to bisect the slit, set the fishtail aperture on the slit for a 2 -mm-high spectrum, and set the automatic timer at $30 \mathrm{~s} ;(2)$ initiate an arc at $3 \mathrm{amp}$ and immediately increase to $10 \mathrm{amp}$ (amperage settings over 10 amp seem only to increase background); (3) position the Hartmann diaphragm to block out the top half of the spectrum when the arc stops after the 30-s burn, reset the timer for $75 \mathrm{~s}$, and re-ignite the arc; and (4) rack the camera $2 \mathrm{~mm}$ on completion of the burn and repeat the sequence for the next sample. The resulting spectrum is $2 \mathrm{~mm}$ high, with the top $1 \mathrm{~mm}$ representing a 30 -s exposure at 100 -percent transmission and the bottom $1 \mathrm{~mm}$ representing a total energy burn (105-s exposure) at 41-percent transmission. As many as 12 exposures can be recorded on each film.

Process the film and obtain results by visual comparison with a master film containing the standards recorded by the same technique. The analytical lines used and the detection limits obtained are given in table 2 .

\section{DISCUSSION OF PROCEDURE}

Excitation and recording of spectrum.-This investigation determined 40 elements whose volatility ranges from highly volatile to highly refractory. Obtaining reliable data on refractory elements requires a total energy burn. Volatile elements present at low concentrations, however, are completely volatilized during the first part of the exposure. Therefore, a split-slit technique described by Mosier (1972) was found useful. The technique utilizes a Hartmann diaphragm and step filter assemblage which enables the simultaneous recording, from the same electrode charge, of volatile elements from a short burn at 100 -percent transmission and of less volatile elements from a total energy burn at 41-percent transmission.

Comparison of spectra.-When possible, the total energy part of the spectrum is used for making comparisons. The short burn part of the spectrum is only used for volatile elements whose concentrations are 


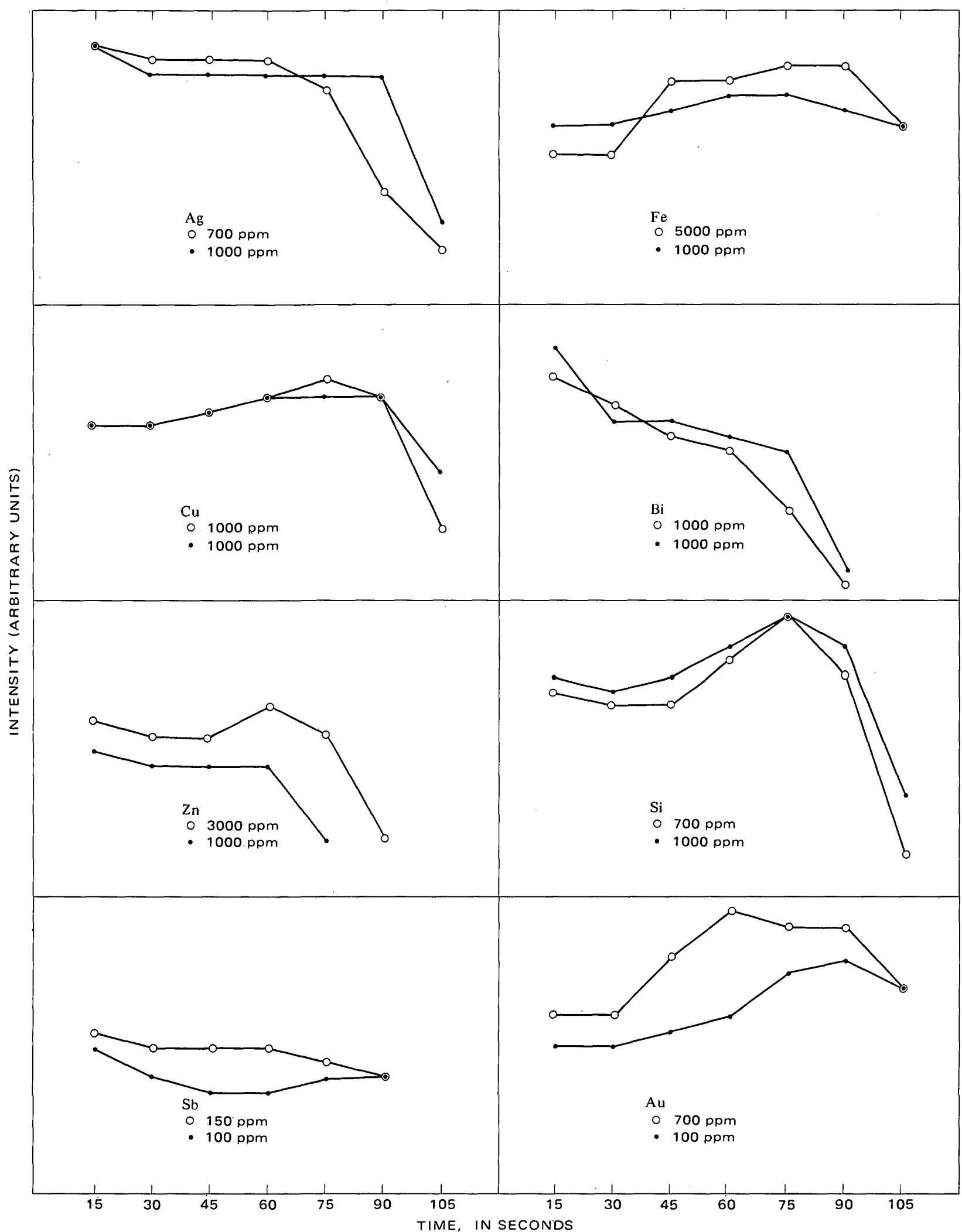

Figure 1.-Comparison of volatilization rates between standards and samples. Dot, standard; open circle, sample. 
TABLE 2.-Analytical lines and detection limits for elements analyzed in galena

\begin{tabular}{|c|c|c|c|c|c|c|c|}
\hline \multicolumn{2}{|c|}{ Element } & \multirow{2}{*}{$\begin{array}{c}\begin{array}{c}\text { Wavelength } \\
(\AA)\end{array} \\
3280.68\end{array}$} & \multirow{2}{*}{$\frac{\begin{array}{c}\text { Detection } \\
\text { limit } \\
(\mathrm{ppm})\end{array}}{0.5}$} & \multicolumn{2}{|c|}{ Flement } & \multirow{2}{*}{$\begin{array}{c}\begin{array}{c}\text { Wavelength } \\
(\AA)\end{array} \\
3337.49\end{array}$} & \multirow{2}{*}{$\frac{\begin{array}{c}\text { Detection } \\
\text { limit } \\
(\mathrm{ppm})\end{array}}{10}$} \\
\hline Ag & I & & & La & II & & \\
\hline & $\vec{I}$ & 3382.89 & 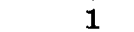 & $\mathrm{Mg}$ & II & 2795.53 & \\
\hline $\mathrm{Al}$ & $\bar{I}$ & 3082.16 & 5 & & II & 2779.83 & 50 \\
\hline \multirow{4}{*}{ As } & I & 2660.39 & 100 & $\mathbf{M n}$ & II & 2939.30 & $\mathbf{5}$ \\
\hline & $\overline{\mathbf{I}}$ & 2780.20 & 20 & & II & 2949.20 & 5 \\
\hline & I & 2349.84 & 50 & Mo & I & 3170.35 & 1 \\
\hline & I & 2860.45 & 100 & & I & 3193.97 & 2 \\
\hline \multirow[t]{2}{*}{$\mathrm{Au}$} & I & 2675.95 & 2 & $\mathrm{Na}$ & I & 3302.32 & 100 \\
\hline & I & 2427.95 & 5 & $\mathrm{Nb}$ & II & 3163.40 & 5 \\
\hline \multirow[t]{2}{*}{ B } & I & 2497.73 & 1 & $\mathrm{Ni}$ & I & 3414.77 & 10 \\
\hline & $\vec{I}$ & 2496.78 & 5 & & $\bar{I}$ & 3101.88 & 20 \\
\hline \multirow{3}{*}{$\begin{array}{l}\mathrm{Ba} \\
\mathrm{Be} \\
\mathrm{Bi}\end{array}$} & II & 4554.04 & 5 & Sb & I & 2598.06 & 10 \\
\hline & I & 2348.6 & 0.5 & & $\bar{I}$ & 2877.92 & 20 \\
\hline & I & 3067.72 & 1 & & $\vec{I}$ & 2670.64 & 500 \\
\hline $\mathbf{B i}$ & $\overline{\mathbf{I}}$ & 2897.98 & 50 & Sc & II & 3353.73 & 2 \\
\hline $\mathbf{C a}$ & I & 4226 . & 1 & Si & I & 2506.90 & \\
\hline $\mathrm{Cd}$ & I & 3261.06 & 5 & Sn & I & 3175.02 & 1 \\
\hline $\mathrm{Ce}$ & II & 3201.71 & 100 & & $\overline{\mathbf{I}}$ & 9.99 & 1 \\
\hline Co & I & 3453.5 & 2 & $\mathrm{Sr}$ & II & & 50 \\
\hline $\mathrm{Cr}$ & I & 4254.35 & 5 & Ta & I & 2933.55 & 50 \\
\hline \multirow[t]{3}{*}{$\mathrm{Cu}$} & $\vec{I}$ & 3247 . & 1 & $\mathrm{Te}$ & $\vec{I}$ & 238 & 20 \\
\hline & $\bar{I}$ & 3273 . & 1 & $\mathbf{T i}$ & II & 3088.02 & 2 \\
\hline & $\bar{I}$ & 824. & 100 & $\mathrm{Tl}$ & I & 2767.87 & 2 \\
\hline \multirow[t]{2}{*}{$\mathrm{Fe}$} & I & 2788.10 & 5 & $\mathrm{~V}$ & I & 3183. & 2 \\
\hline & I & 2869.31 & 2,000 & $\mathrm{~W}$ & I & 2946 . & 20 \\
\hline \multirow{5}{*}{$\begin{array}{l}\mathrm{Ga} \\
\mathrm{Ge} \\
\mathrm{Hg}\end{array}$} & I & 2943.64 & 2 & $\mathbf{Y}$ & II & 3327.88 & 10 \\
\hline & I & 3039.06 & 1 & & II & 3242.28 & 2 \\
\hline & I & 2536.52 & 50 & $\mathrm{Zn}$ & I & 3345.02 & 50 \\
\hline & I & 3039.36 & 5 & & I & 3302.59 & 50 \\
\hline & I & 3256.09 & 2 & $\mathrm{Zr}$ & II & 3391.98 & 5 \\
\hline
\end{tabular}

below the detection limits of the total energy burn. Dilutions were made with pure lead sulfide to obtain results for those samples having elements in concentrations greater than the maximum concentration of the standards.

\section{ACCURACY AND PRECISION}

The precision of the method was checked by the analysis of four samples, each of which was analyzed at least 10 times over a period of several days in a completely randomized sequence to guard against biased results. The average and range of values reported and the coefficient of variation for all elements found are listed in table 3 . The coefficient of variation is generally between 10 and 30 percent, which is the precision generally ascribed to six-step semiquantitative spectrographic methods. When the limit of detection is approached, coefficient of variation values tend to be higher.

In a six-step semiquantitative method which is based on orders of magnitude, reported values represent approximate midpoints of a concentration interval on a geometric scale, as discussed under "Standards." Checks in the U.S. Geological Survey analytical lab-

TABLE 3.-Data on the precision of the spectrochemical method from multiple analyses of four selected samples [All values given in parts per million excent coefficient of variation, $C$, given in percent; $C=\frac{100}{\bar{X}} \sqrt{\frac{\Sigma}{n-1}}$, where $\bar{X}=$ average concentration in parts per million, $d=$ difference of the determination from mean, and $n=$ number of determinations ]

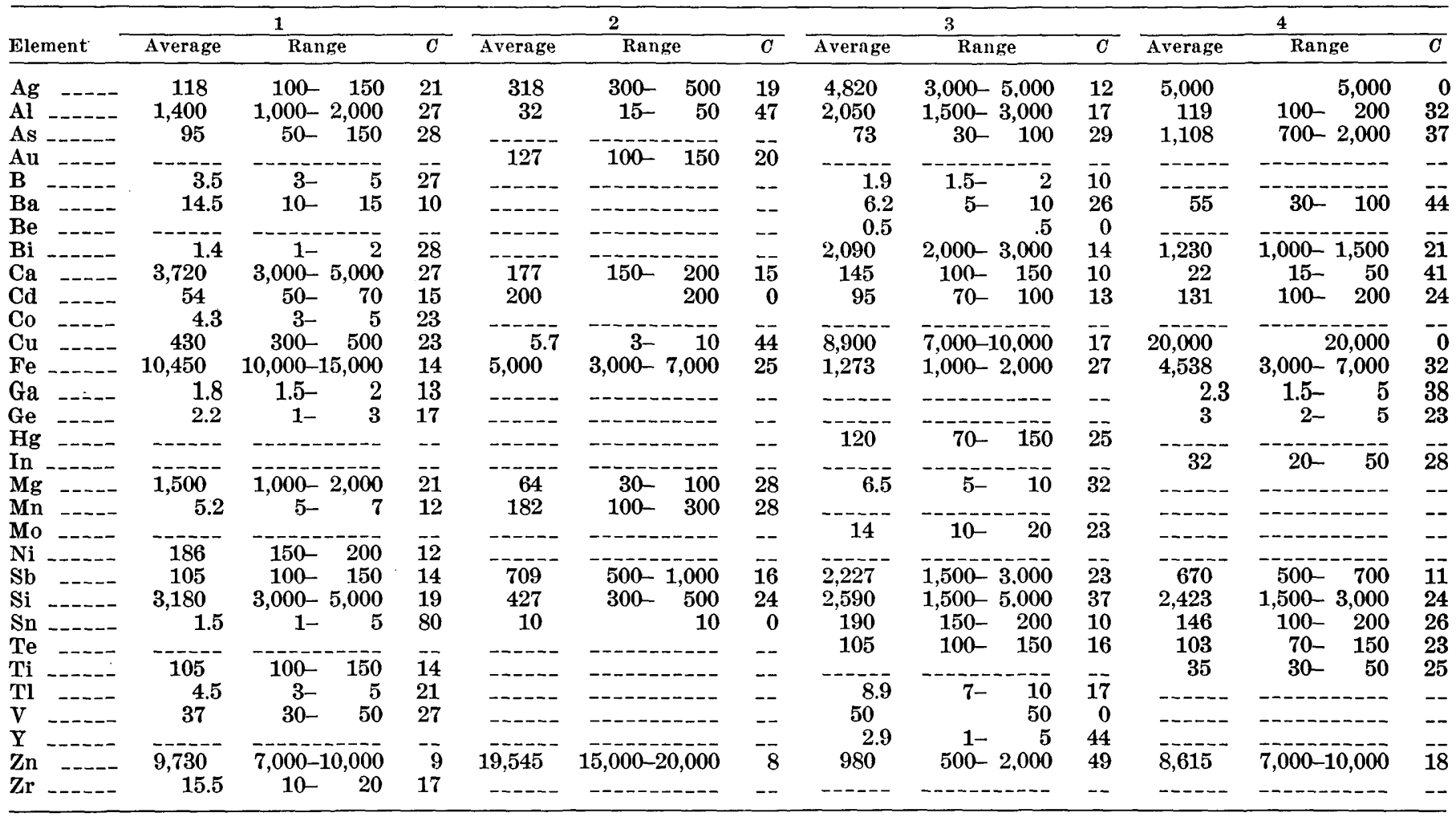


oratories show that reported values on the same material using six-step semiquantitative methods will lie within the same standard interval about 60 percent of the time and within the next adjacent standard interval on either side 95 percent of the time.

No data on the accuracy of this method are available; however, experience with six-step semiquantitative methods for the analysis of other geologic materials indicates that similar precision and accuracy are obtained.

\section{RESULTS}

The primary objective of this work was to develop a semiquantitative spectrographic procedure for the analysis of galena and other sulfide concentrates which could be utilized in exploration geochemistry. Reference standards with wide compositional ranges and widely divergent volatilization characteristics were prepared, and the procedure was designed to fulfill the requirements of that primary objective. The galena concentrates, as already mentioned, vary greatly in purity. Some were painstakingly purified by handpicking clean crystals, which were gently ground, superpanned in heavy liquids, and then again handpicked with the aid of a microscope to obtain crystals free of stains and free of inclusions. Others were obtained by ordinary panning of galena-poor sulfide samples that yielded only a few milligrams of impure galena accompanied by mineralogic trash. The modes of occurrence (isomorphous substitutions, as sorbed ions as in solid or fluid inclusions, as crystal intergrowths and overgrowths, or as accessory minerals not entirely removed from the concentrates) of elements other than lead and sulfur are important in interpretation and utilization of the analytical data, but such a discussion is beyond the scope of this paper.

TABLE 4.-Summary of semiquantitative spectrographic data on minor elements in 129 sulfide concentrates that are mainly galena

\begin{tabular}{|c|c|c|c|c|c|c|c|c|c|c|c|c|c|c|}
\hline \multirow{2}{*}{\multicolumn{2}{|c|}{ Element }} & \multirow[b]{2}{*}{$\begin{array}{c}\text { Maximum } \\
\text { concen- } \\
\text { tration } \\
(\mathrm{ppm})\end{array}$} & \multicolumn{9}{|c|}{$\begin{array}{c}\text { Number of samples in which element was detected, } \\
\text { at indicated concentration (ppm)* }\end{array}$} & \multicolumn{2}{|c|}{$\begin{array}{c}\text { Number } \\
\text { of samples }\end{array}$} & \multirow{2}{*}{$\begin{array}{l}\text { Percent } \\
\text { of } \\
\text { samples } \\
\text { in which } \\
\text { element } \\
\text { detected }\end{array}$} \\
\hline & & & $>10,000$ & $\begin{array}{r}5,000 \\
7,000 \\
10,000 \\
\end{array}$ & $\begin{array}{l}1,500 \\
2,000 \\
3,000 \\
\end{array}$ & $\begin{array}{r}500 \\
700 \\
1,000 \\
\end{array}$ & $\begin{array}{l}150 \\
200 \\
300 \\
\end{array}$ & $\begin{array}{r}50 \\
70 \\
.100 \\
\end{array}$ & $\begin{array}{l}15 \\
20 \\
30 \\
\end{array}$ & $\begin{array}{r}5 \\
7 \\
10 \\
\end{array}$ & $<5$ & $\begin{array}{c}\text { Ele- } \\
\text { ment } \\
\text { not } \\
\text { de- } \\
\text { tected }\end{array}$ & $\begin{array}{c}\text { Ele- } \\
\text { ment } \\
\text { de- } \\
\text { tected }\end{array}$ & \\
\hline Ag & - - - - - - - - & 20,000 & $\mathbf{3}$ & 20 & 20 & 43 & 38 & 4 & 1 & 0 & 0 & 0 & 129 & 100 \\
\hline Al & 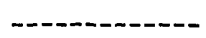 & 5,000 & 0 & 1 & 5 & 10 & 33 & 41 & $3 \overline{3}$ & 5 & 1 & 0 & 129 & 100 \\
\hline As & - - - - - - - & 30,000 & 2 & 4 & $\mathbf{3}$ & 12 & 11 & 20 & 16 & 0 & 0 & 61 & 68 & 52.7 \\
\hline B & 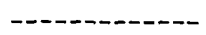 & 7 & 0 & 0 & 0 & 0 & 0 & 0 & 0 & 2 & 4 & 123 & 6 & 4.7 \\
\hline $\mathbf{B a}$ & - & 10,000 & 0 & 2 & 3 & 9 & 12 & 17 & 17 & 11 & 1 & 57 & 72 & 55.8 \\
\hline $\mathrm{Be}$ & $-\cdots-\cdots-\cdots$ & 3 & 0 & 0 & 0 & 0 & 0 & 0 & 0 & 0 & 12 & 117 & 12 & 9.3 \\
\hline $\mathrm{Bi}$ & $-\cdots-\infty-\infty-\infty-0$ & 50,000 & 5 & 11 & 11 & 13 & 8 & 18 & 15 & 12 & 26 & 10 & 119 & 92.2 \\
\hline $\mathrm{Ca}$ & $-\infty-\infty-\cdots$ & $\mathbf{3 0 , 0 0 0}$ & 1 & 3 & 6 & 14 & 26 & 36 & 24 & 11 & 8 & 0 & 129 & 100 \\
\hline Cd & $---0-0-1-n$ & $\mathbf{3 , 0 0 0}$ & 0 & 0 & 1 & 5 & 15 & 49 & 50 & 8 & 0 & 1 & 128 & 99.2 \\
\hline $\mathrm{Ce}$ & --n- & 3,000 & 0 & 0 & $\mathbf{3}$ & $\mathbf{5}$ & 5 & 4 & 0 & 0 & 0 & 112 & 17 & 13.2 \\
\hline Co & --1-- - & 30 & 0 & 0 & 0 & 0 & 0 & 0 & 12 & 21 & 6 & 90 & 39 & 30.2 \\
\hline $\mathrm{Cr}$ & 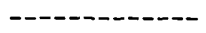 & 30 & 0 & 0 & 0 & 0 & 0 & 0 & 4 & 6 & 0 & 119 & 10 & 7.8 \\
\hline $\mathrm{Cu}$ & $----\cdots---\cdots$ & 30,000 & 2 & 11 & 17 & 40 & 26 & 18 & 9 & 4 & 2 & 0 & 129 & 100 \\
\hline Ga & 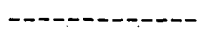 & $\mathbf{3 0}$ & 0 & 0 & 0 & 0 & 0 & 0 & 1 & 5 & 11 & 112 & 17 & 13.2 \\
\hline Ge & 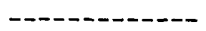 & 20 & 0 & $\mathbf{0}$ & $\mathbf{0}$ & $\mathbf{0}$ & 0 & $\mathbf{0}$ & 1 & 2 & 6 & 120 & 9 & 7.0 \\
\hline Hg & - - - - - & 1,000 & 0 & $\mathbf{0}$ & 0 & 1 & 0 & 4 & 0 & 0 & 0 & 124 & 5 & 3.9 \\
\hline In & - & 50 & 0 & $\mathbf{0}$ & 0 & 0 & 0 & 1 & $\mathbf{3}$ & 1 & 5 & 119 & 10 & 7.8 \\
\hline La & 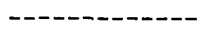 & 2,000 & 0 & 0 & 2 & 2 & $\mathbf{5}$ & 9 & 4 & 6 & $\mathbf{0}$ & 101 & 28 & 21.7 \\
\hline $\mathbf{M g}$ & - - - - - - & 5,000 & 0 & 1 & 4 & 11 & 4 & 23 & 46 & 35 & $\mathbf{5}$ & 0 & 129 & 100 \\
\hline Mn & $---------\infty$ & 15,000 & 1 & 2 & 6 & 14 & 12 & 20 & 24 & 18 & 12 & 20 & 109 & 84.5 \\
\hline Mo & - - & 700 & 0 & $\mathbf{0}$ & $\mathbf{0}$ & 2 & 2 & 7 & 10 & 8 & 25 & 75 & 54 & 41.9 \\
\hline $\mathrm{Na}$ & - & 150 & 0 & $\mathbf{0}$ & 0 & 0 & 2 & 3 & 0 & 0 & 0 & 124 & $\mathbf{5}$ & 3.9 \\
\hline $\mathrm{Nb}$ & - - - & 200 & 0 & 0 & 0 & 0 & 1 & 3 & 2 & $\mathbf{5}$ & $\mathbf{0}$ & 118 & 11 & 8.5 \\
\hline $\mathrm{Ni}$ & - & 200 & 0 & 0 & 0 & 0 & 6 & 4 & 20 & 7 & $\mathbf{0}$ & 92 & 37 & 28.7 \\
\hline Sb & - - & 30,000 & 5 & 6 & 10 & 35 & 38 & 22 & $\mathbf{5}$ & $\mathbf{3}$ & 0 & $\mathbf{5}$ & 124 & 96.1 \\
\hline Sc & - - - - & 100 & n & 0 & 0 & 0 & 0 & 3 & 0 & 3 & 1 & 122 & 7 & 5.4 \\
\hline Si & 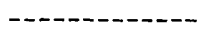 & 20,000 & 2 & 11 & 33 & 28 & 29 & 17 & 7 & 2 & 0 & 0 & 129 & 100 \\
\hline Sn & - & 700 & 0 & 0 & 0 & 1 & 6 & 12 & 18 & 14 & 21 & $\mathbf{5 7}$ & 72 & 55.8 \\
\hline Sr & - - - & $\mathbf{5 , 0 0 0}$ & 0 & 1 & 0 & $\mathbf{3}$ & 8 & 22 & 6 & 0 & $\mathbf{0}$ & 89 & 40 & 31.0 \\
\hline $\mathbf{T a}$ & - & N.D. & 0 & $\mathbf{0}$ & $\mathbf{0}$ & 0 & 0 & 0 & 0 & 0 & $\mathbf{0}$ & 129 & $\mathbf{0}$ & 0 \\
\hline Te & - - & 5,000 & 0 & 2 & 1 & 2 & 10 & 15 & 6 & 0 & 0 & 93 & 36 & 27.9 \\
\hline $\mathbf{T i}$ & - - & 300 & 0 & 0 & $\mathbf{0}$ & 0 & 6 & 17 & 24 & 22 & 11 & 49 & 80 & 62.0 \\
\hline W & - & 50,000 & 2 & 1 & 4 & 2 & 3 & 2 & 2 & 0 & 0 & 113 & 16 & 12.4 \\
\hline $\mathbf{Y}$ & --n-- - - - - & 500 & 0 & 0 & 0 & 3 & 3 & 10 & 4 & 5 & 7 & 97 & 32 & 24.8 \\
\hline $\mathrm{Zn}$ & 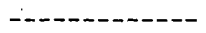 & 150,000 & 21 & 28 & 17 & 24 & 12 & 18 & $\mathbf{3}$ & 0 & 0 & 6 & 123 & 95.3 \\
\hline $\mathrm{Zr}$ & 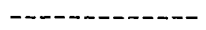 & 20,000 & 3 & 2 & 6 & 7 & 3 & 7 & 11 & 17 & 1 & 72 & 57 & 44.2 \\
\hline
\end{tabular}

* Concentration groupings arbitrarily selected ; for text discussion of reporting intervals see "Standards." 
A summary of results of the semiquantitative spectrographic analyses of 129 samples (table 4 ) shows an impressive number of elements of interest to exploration geochemists. Because the samples are galena concentrates, lead is a major constituent in all samples and accordingly is not shown in the analyses. In addition to lead, 39 elements of the 40 studied were detected; tantalum was the only element studied that was not detected in any of the samples. $\mathrm{Ag}, \mathrm{Al}, \mathrm{Ca}, \mathrm{Cu}$, $\mathrm{Mg}$, and $\mathrm{Si}$ were found in all samples and $\mathrm{Cd}$ and $\mathrm{Fe}$ in all but one; however, $\mathrm{B}, \mathrm{Be}, \mathrm{Cr}, \mathrm{Ge}, \mathrm{Hg}, \mathrm{In}, \mathrm{Na}$, $\mathrm{Nb}, \mathrm{Sc}$, and $\mathrm{V}$ were detected in less than 10 percent of the samples.

Many chalcophile elements $(\mathrm{Ag}, \mathrm{As}, \mathrm{Bi}, \mathrm{Cd}, \mathrm{Cu}, \mathrm{Sb}$, $\mathrm{Zn}$ ) are well represented in the results, but other chalcophile elements ( $\mathrm{Ga}, \mathrm{Hg}$, In, $\mathrm{Te}, \mathrm{Tl}$ ) occur in generally small amounts, and in a comparatively small percentage of the samples. Except for As, Cu, Ga, and $\mathrm{Zn}$, all these elements have crustal abundances less than $1 \mathrm{ppm}$ (Levinson, 1974 , p. 43-44), and their concentrations in some samples represent substantial enrichments. There are also interesting occurrences of the siderophile elements, $\mathrm{Au}, \mathrm{Mo}$, and $\mathrm{Sn} . \mathrm{Au}$ and $\mathrm{Mo}$ were observed in more than a third of the samples and Sn was observed in more than half. It is noteworthy that the concentrations of gold in two samples exceeded 1 percent $(10,000 \mathrm{ppm})$. Although many lithophile elements were found, three that stand out are $\mathrm{Ba}, \mathrm{Mn}$, and $\mathrm{W}-\mathrm{Ba}$ and $\mathrm{Mn}$ because of the possibility of their geochemical involvement in mineralizing processes, and $\mathrm{W}$ because of its low crustal abundance (1.5 ppm as listed in Levinson, 1974). Sixteen samples contained detectable $\mathrm{W}$ and two contained more than 1 percent.

\section{DISCUSSION AND CONCLUSION}

This spectrochemical method for the analysis of galena-rich concentrates should be useful in exploration geochemistry. The method was designed specifically for the analysis of trace elements.in galena con: centrates that do not necessarily meet the high-purity requirements demanded for mineral zoning or o isomorphous substitution studies. Such galenas can be recovered quickly and easily by ordinary panning of pulverized rock or ore samples that contain galena, even if only in trace amounts, and they can be rapidly analyzed for a large number of elements. The detection of elements such as gold, tin, or tungsten, and measurements on their concentrations could suggest profitable exploration activities aimed at these elements. Galena samples high in elements such as silver, antimony, bismuth, cadmium, or thallium might be more worthy of further consideration than those with insignificant amounts of such elements. The presence of certain elements such as antimony, barium, arsenic, molybdenum, tin, tungsten, or tellurium may reflect ore depositional conditions, and thereby enable predictions as to the configuration of ore zonation.

\section{REFERENCES CITED}

Bastron, Harry, Barnett, P. R., and Murata, K. J., 1960, Method for the quantitative spectrochemical analysis of rocks, minerals, ores and other materials by a powder d-c arc technique: U.S. Geol. Survey Bull. 1084-G, 165-182.

Bethke, P. M., and Barton, P. B. Jr., 1971, Distribution of some minor elements between coexisting sulfide minerals: Econ. Geology, v. 66, p. 140-163.

Chakrabarti, Anada K., 1967, On the trace element geochemistry of Zawar sulfides and its relation to metallogenesis: Canadian Mineralogist, v. 9, pt. 2, p. 258-262.

Delevaux, M. H., Pierce, A. P., and Antweiler, J. C., 1966, New isotopic measurements of Colorado ore leads, in Geological Survey research 1966: U.S. Geol. Survey Prof. Paper 550-C, p. C178-C186.

Fleischer, Michael, 1955, Minor elements in some sulfide minerals: Econ. Geology 50th anniversary volume, pt. 2, p. 970-1024.

Graeser, Stefan, 1969, Minor elements in sphalerite and galena from Binnatal-Relations to coloration problems, isotopic composition, etc. : Contr. Mineralogy and Petrology, v. 24, pt. 2 , p. $156-163$.

Grimes, D. J., and Marranzino, A. P., 1968, Direct-current arc and alternating-current spark emission spectrographic field. methods for the semiquantitative analysis of geologic materials: U.S. Geol. Survey Circ. 591, 6 p.

Hall, W. E., and Heyl, A. V., 1968, Distribution of minor elements in ore and host rock, Illinois-Kentucky fluorite district and Upper Mississippi Valley zinc-lead district: Econ. Geology, v. 63, p. 655-670.

Hall, W. E., Rose, H. J., Jr., and Simon, Frederick, 1971, Fractionation of minor elements between galena and sphalerite, Darwin lead-silver-zinc mine, Inyo County, California and its significance in geothermometry : Econ. Geology, v. 66, p. 602-606.

Levinson, A. A., 1974, Introduction to exploration geochemistry : Calgary, Applied Publishing, Itd:, 612 p:

Malakhov, A. A., 1968, Bismuth and :antimony in galena as indicators of some conditions of ore deposit formation: Geokhimiya, v. 11, p. 1283-1296.

Marshall, R: R., and Joensuu, Oiva, 1961, Crystal habit and trace element content of some galenas: Econ. Geology, v. 56, p. $758-771$.

Mosier, E. L., 1972, A method for semiquantitative spectrographic analysis of plant ash for use in biogeochemical and environmental studies: Applied Spectroscopy, v. 26, p. 636-641.

Myers, A. T., Havens, R. G., and Dunton, P. J., 1961, A spectro-chemical method for semiquantitative analysis of rocks, minerals, and ores: U.S. Geol. Survey Bull. 1084-I, p. 207229.

Rivas, S., and Pinto, C., 1967, Quantitative spectral analysis of galenas: Rev. Minera Geologia y Mineralogia, v. 28, p. 7, 8 .

Ward, F. N., Lakin, H. W., Canney, F. C., and others, 1963, Analytical methods used in geochemical exploration by the U.S. Geological Survey : U.S. Geol. Survey Bull. 1152, 100 p. 


\section{RECENT PUBLICATIONS OF THE U.S. GEOLOGICAL SURVEY}

(The following books may be ordered from the U.S. Geological Survey, 1200 South Eads Street, Arlington, VA 22202 (an authorized agent of the Superintendent of Documents, Government Printing Office). Prepayment is required. Remittances should be sent by check or money order payable to U.S. Geological Survey. Give series designation and number, such as Bulletin 1368-A, and the full title. Prices of Government publications are subject to change. Increases in costs make it necessary for the Superintendent of Documents to increase the selling prices of many publications offered. As it is not feasible for the Superintendent of Documents to correct the prices manually in all the publications stocked, the prices charged on your order may differ from the prices printed in the publications and in this list)

\section{Professional Papers}

437-F. Land subsidence due to ground-water withdrawal in the Los Banos-Kettleman City area, California, Part 2. Subsidence and compaction of deposits, by W. B. Bull. 1975. p. F1-F90. $\$ 2.25$.

437-G. Land subsidence due to ground-water withdrawal in the Los Banos-Kettleman City area, California, Part 3. Interrelations of water-level change, change in aquifersystem thickness, and subsidence, by W. B. Bull and J. F. Poland. 1975. p. G1-G62. \$1.90.

486-K. Geohydrologic reconnaissance of the Imperial Valley, Calif, by O. J. Loeltz., Burdge Irelan, J. H. Robison, and F. H. Olmsted. 1975. p. K1-K54. $\$ 2.85$.

806. Geology of the Chewelah-Loon Lake area, Stevens and Spokane Counties, Wash., by F. K. Miller and L. D. Clark, with a section on Potassium-argon ages of the plutonic rocks, by J. C. Engels. 1975. 74 p. ; plates in pocket. $\$ 2.15$.

813-D. Summary appraisals of the Nation's ground-water resources-Rio Grande Region, by S. W. West and W. L. Broadhurst. 1975. p. D1-D39. \$1.25.

837. The logic of geological maps, with reference to their interpretation and use for engineering purposes, by $\mathrm{D}$. J. Varnes, 1974 (1975). $48 \mathrm{p}$.; plates in pocket. $\$ 3.50$.

843-A. Distribution of gold and other ore-related elements near ore bodies in the oxidized zone at Goldfield, Nev., by R. P. Ashley and J. P. Albers, 1975, p. A1-A48; plates in pocket. $\$ 3$.

846. Structural evolution of the northernmost Andes, Colombia by E. M. Irving. 1975. 47 p.; plates in pocket. $\$ 1.30$.

855. Geology of the Sage and Kemmerer 15-minute quadrangles, Lincoln County, Wyo., by W. W. Rubey, S. S. Oriel, and J. I. Tracey, Jr., 1975. 18 p.; plates in pocket. $\$ 2.25$.

867-A. Stratigraphy of Paleozoic rocks in the Carlin-Pinon Range area, Nevada, by J. F. Smith, Jr. and K. B. Ketner. 1975. p. A1-A87; plates in pocket. $\$ 3.60$.

875. Deformations associated with relaxation of residual stresses in a sample of Barre Granite from Vermont, by T. C. Nichols, Jr. 1975.32 p. $\$ 1.25$.

900. Geological Survey research 1974. 1974 (1975). 349 p. $\$ 6.10$.

912. Petroleum geology of Naval Petroleum Reserve No. 1, Elk Hills, Kern County, Calif., by J. C. Maher, R. D. Carter, and R. J. Lantz. 1975. 109 p.; plates in separate case. $\$ 15.75$.

\section{Bulletins}

1310. Coal resources and Cenozoic geology of the Girard coal field, Richland County, Mont., by G. E. Prichard and E. R. Landis. 1975.89 p. ; plates in pocket. $\$ 2.60$.

1329. Lithology and uranium potential of Jurassic formations in the San Ysidro-Cuba and Majors Ranch areas, northwestern New Mexico, by E. S. Santos. 1975, 22 p. $\$ 1.60$.
1385-C. Mineral resources of the San Pedro Parks Wilderness and vicinity, Rio Arriba and Sandoval Counties, N. Mex., by E. S. Santos, R. B. Hall, and R. C. Weisner. 1975. p. C1-C29; plate in pocket. $\$ 1.75$.

1392. Hornblendes from a region of high-grade metamorphism, Front Range, Colo., by D. J. Gable and V. C. Smith. 1975 . 35 p. $70 \phi$.

1395-B. Revision of the Type Mancomen formation (Pennsylvanian and Permian), Eagle Creek area, Eastern Alaska Range, Alaska, by D. H. Richter and J. T. Dutro, Jr. 1975. p. B1-B25. $65 \phi$

1395-F. Alsea Formation-an Oligocene marine sedimentary sequence in the Oregon Coast Range, by P. D. Snavely, Jr., N. S. MacLeod, W. W. Rau, W. O. Addicott, and J. E. Pearl. 1975. p. F1-F21. 65

1395-G. Coughs Creek Tongue-A new tongue of the Eocene Green River Formation, Piceance Creek basin, Colorado, by R. B. O'Sullivan. 1975. p. G1-G7. 40ф.

1395-H. Geologic setting of the Glacier Peak and Mazama ash-bed markers in west-central Montana, by $R$. W. Lemke, M. R. Mudge, R. E. Wilcox, and H. A. Powers. 1975. p' H1-H31. $70 \phi$

\section{Water-Supply Papers}

2023. Selenium in waters in and adjacent to the Kendrick project,' Natrona County,' Wyo.,' by M. A. Crist. 1974 (1975). $39 \mathrm{p}$.; plates in pocket. $\$ 2.85$.

2035. Geohydrologic reconnaissance of the upper Potomac River basin, by F. W. Trainer and F. A. Watkins, Jr. 1975. $68 \mathrm{p}$.; plate in pocket. $\$ 1.95$.

2104. Surface water supply of the United States, 1966-70Part 2, South Atlantic slope and eastern Gulf of Mexico basins-Volume 1, Basins from James River to Savannah River. 1974 (1975). 1,018 p. $\$ 6.60$.

2111. Surface water supply of the United States, 1966-70Part 4, St. Lawrence River basin-Volume 1, Basins of streams tributary to Lakes Superior, Michigan, and Huron, 1974. (1975'. 754 p. $\$ 5.10$.

2116. Surface water supply of the United States, 1966-70Part 6, Missouri River basin-Volume 1, Missouri River basin above Williston, N. Dak. 1974 (1975). 835 p. $\$ 5.60$. Part 8. Western Gulf of Mexico basins-Volume 2. Basins

2121. Surface water supply of the United States, 1966-70Part 7, Lower Mississippi River basin-Volume 2, Arkansas River basin. 1974 (1975). 931 p. $\$ 6.15$.

2123. Surface water supply of the United States, 1966-70Part 8, Western Gulf of Mexico basins-Volume 2, Basins from Lavaca River to Rio Grande. 1974 (1975). 861 p. $\$ 5.70$.

2127. Surface water supply of the United States, 1966-70Part 10, The Great Basin. 1974 (1975). 1,143 p. $\$ 7.35$.

2143. Quality of surface waters of the United States, 1969Part 3, Ohio River basin. 1974 (1975). 371 p. $\$ 2.85$. 
U.S. GOVERNMENT

PRINTING OFFICE

PUBLIC DOCUMENTS EEPABTMENT

WASHINGTON, D.C. 20402

OFFICIAL PUSINESS

PEnalty fót phivate USE $\$ 300$
POSTAGE AND FEES PAID U.S. GOVERNMENT PAINTING OFFICE 375 